\title{
The Tiberian Pronunciation Tradition of Biblical Hebrew
}

\author{
Volume II
}

\section{GeOfFREY KhAN}

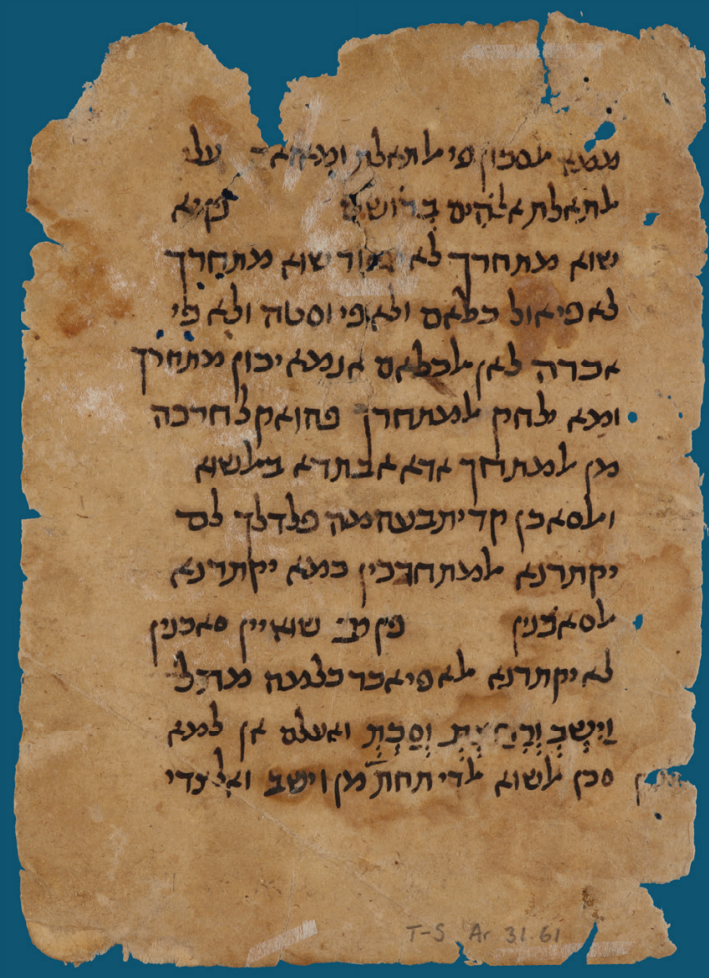




\section{THE TIBERIAN PRONUNCIATION TRADITION OF BIBLICAL HEBREW}

VOLUME II 



\section{The Tiberian Pronunciation Tradition of Biblical Hebrew}

Including a Critical Edition and English Translation of the Sections on

Consonants and Vowels in the Masoretic Treatise

Hidāyat al-Qāri' 'Guide for the Reader'

Volume II

Geoffrey Khan 
https://www.openbookpublishers.com

(C) 2020 Geoffrey Khan.

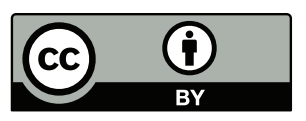

This work is licensed under a Creative Commons Attribution 4.0 International license (CC BY 4.0). This license allows you to share, copy, distribute and transmit the text; to adapt the text and to make commercial use of the text providing attribution is made to the authors (but not in any way that suggests that they endorse you or your use of the work). Attribution should include the following information:

Geoffrey Khan, The Tiberian Pronunciation Tradition of Biblical Hebrew, Volume II. Cambridge, UK: Open Book Publishers, 2020, https://doi.org/10.11647/OBP.0194

In order to access detailed and updated information on the license, please visit, https:// doi.org/10.11647/OBP.0194\#copyright

Further details about CC BY licenses are available at, https://creativecommons.org/ licenses/by/4.0/

All external links were active at the time of publication unless otherwise stated and have been archived via the Internet Archive Wayback Machine at https://archive.org/web

Updated digital material and resources associated with this volume are available at https://doi.org/10.11647/OBP.0194\#resources

Every effort has been made to identify and contact copyright holders and any omission or error will be corrected if notification is made to the publisher.

Semitic Languages and Cultures 1, volume 2.

ISSN (print): 2632-6906

ISSN (digital): 2632-6914

ISBN Paperback: 978-1-78374-857-0

ISBN Hardback: 978-1-78374-858-7

ISBN Digital (PDF): 978-1-78374-859-4

DOI: $10.11647 / \mathrm{OBP} .0194$

Cover image: Cambridge University Library T-S Ar. 31.61 (Hidāyat al-Qāri'). Courtesy of the Syndics of Cambridge University Library

Cover design: Luca Baffa. 


\section{Volume II}

Edition and English Translation of the Sections on Consonants and Vowels in the Masoretic Treatise

Hidāyat al-Qāri' 'Guide for the Reader' 



\section{CONTENTS}

II. INTRODUCTION ............................................................... 1

II.Int.0.1. Preliminary Remarks.......................................... 1

II.Int.0.2. The Long Version .............................................. 2

II.Int.0.3. The Short Version ............................................ 5

II.Int.0.4. The Manuscript Corpus ...................................... 8

II.Int.0.5. The Edition and Translation of the Texts............ 11

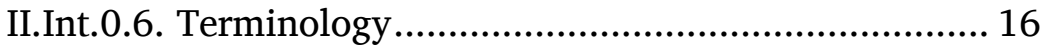

II.Int.0.6.1. Arabic Terms ............................................. 16

II.Int.0.6.2. Hebrew and Aramaic Terms ...................... 19

HIDĀYAT AL-QĀRI' (LONG VERSION)............................... 24

II.L.0.0. INTRODUCTION ............................................... 24

II.L.1.0. THE FIRST DISCOURSE: ON THE LETTERS.......... 40

II.L.1.1. Preliminary Discussion concerning the Nature of

Letters ........................................................ 40

II.L.1.2. Section concerning the Inventory of Letters ..... 48

II.L.1.3. Chapter concerning the Place of Articulation of the Letters ................................................. 48

II.L.1.4. Section concerning some General Issues relating to Letters .................................................. 58

II.L.1.5. Chapter on the Interchange of Letters .............. 66

II.L.1.6. Chapter concerning the Influence of the Four Letters 'alef, vav, yod and he on the Six Letters 

II.L.1.7. Section on Deviations from the General Rule ... 76 
II.L.1.8. Section on Further General Issues Relating to אוֹ .90

II.L.1.9. Chapter concerning Letters that Occur in Three Grades .94

II.L.1.10. Conjugations .98

II.L.1.11. Chapter concerning the Occurrence of Letters for the Sake of Enhancement...........................100

II.L.1.12. Section (more on Enhancement) ...................106

II.L.1.13. Chapter on Contraction..................................110 II.L.2.0. THE SECOND DISCOURSE ...............................116

II.L.2.1. Preliminary Remarks on Vowels .....................116 II.L.2.2. Chapter concerning the Number of the Vowels and those of them that are 'High', those of them that are 'Level' and those of them that are 'Low', and what is Connected to this ...118

II.L.2.3. Section concerning what Corresponds to (Arabic) Inflectional Vowels 122

II.L.2.4. Section on the Correspondence (of Hebrew Vowels) to Arabic Inflectional Vowels 124

II.L.2.5. Section on $R a f^{c}$. 126

II.L.2.6. Section on the Second Raf 128

II.L.2.7. Section on Naṣb 128

II.L.2.8. Section on Khafd. 130

II.L.2.9. Section (Preliminary Remarks on the Shewa)..132

II.L.2.10. Section concerning the Shewa. 132

II.L.2.11. Section on the Nature of Mobile Shewa. 136

II.L.2.12. Chapter concerning the Mobile Shewa and what is Related to this 138 
II.L.2.12.1. The First Subsection ............................ 138

II.L.2.12.2. The Second Subsection ......................... 144

II.L.2.12.3. The Third Subsection............................ 146

II.L.2.12.4. The Fourth Subsection ......................... 150

II.L.2.12.5. The Fifth Subsection ............................. 154

II.L.2.12.6. The Sixth Subsection ........................... 154

II.L.2.12.7. The Seventh Subsection........................ 156

II.L.2.12.8. The Eighth Subsection ......................... 160

II.L.2.12.9. The Ninth Subsection ........................... 162

II.L.2.12.10. The Tenth Subsection ......................... 164

II.L.2.12.11. The Eleventh Subsection..................... 164

II.L.2.12.12. The Twelfth Subsection ..................... 164

II.L.2.12.13. The Thirteenth Subsection.................. 166

II.L.2.12.14. The Fourteenth Subsection ................ 168

II.L.2.13. Section concerning Uncertainty regarding the

Reading of the Shewa .............................. 168

II.L.2.14. Section on the Names of the Vowels ............ 172

II.L.2.15. Section on their Place of Articulation........... 172

II.L.2.16. Section concerning Combinations of them (i.e.

the Vowels) to Form Basic Nouns and Combinations of them to Form Abstractions ....... 174

II.L.2.17. Chapter concerning the Descending of the Vowels from One to the Other according to the Order of their Places of Articulation ......... 176

II.L.2.18. On the Origin of the Vowels........................ 178 II.L.3.0. THE THIRD DISCOURSE: ON THE ACCENTS (SELECTED PASSAGES) ................................... 182

II.L.3.1. On the Gacya .......................................... 182 
II.L.3.2. Chapter concerning Cases whose Rule is not at all Dependent on an Accent and Cases whose Rule is Dependent on an Unspecified Accent ..... 184

HIDĀYAT AL-QĀRI' (SHORT VERSION) 194

II.S.0.0. INTRODUCTION 194

II.S.1.0. SECTION CONCERNING THE PLACE OF ARTICULATION OF THE LETTERS 198

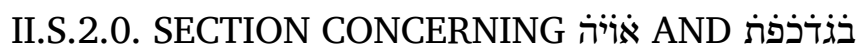
204

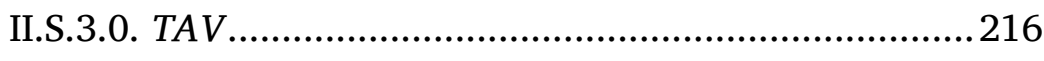

II.S.4.0. SECTION CONCERNING THE VOWELS...............218

II.S.5.0. SECTION CONCERNING THE SHEWA.................222

II.S.6.0. MOBILE SHEWA ...........................................230

II.S.6.1. The First Subsection....................................230

II.S.6.2. The Second Subsection ................................232

II.S.6.3. The Third Subsection .....................................236

II.S.6.4. The Fourth Subsection ................................2236

II.S.6.5. The Fifth Subsection ....................................236

II.S.6.6. The Sixth Subsection....................................238

II.S.6.7. The Seventh Subsection ................................240

II.S.6.8. The Eighth Subsection .................................240

II.S.6.9. The Ninth Subsection....................................240

II.S.6.10. The Tenth Subsection .................................240

II.S.6.11. The Eleventh Subsection ..............................242

II.S.6.12. The Twelfth Subsection ...............................242

II.S.6.13. The Thirteenth Subsection ...........................242

II.S.6.14. The Fourteenth Subsection ..........................244

II.S.7.0. SECTION ON THE NAMES OF THE VOWELS AND 
II.S.8.0. DISCUSSION CONCERNING THEIR PLACE OF ARTICULATION ............................................. 250

II.S.9.0. SECTION CONCERNING THE $G A^{\top} Y A$................. 252

COMMENTARY ON HIDĀYAT AL-QĀRI' ........................... 254

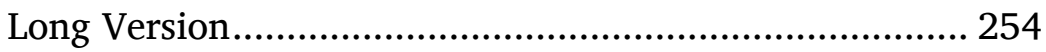

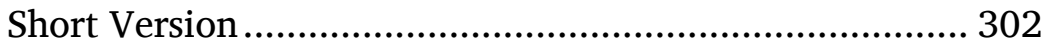

REFERENCES AND ABBREVIATIONS ............................... 305

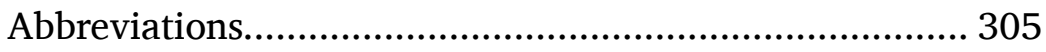

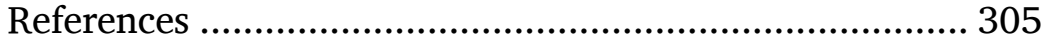

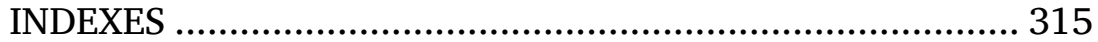





\section{INTRODUCTION}

\section{II.INT.0.1. PRELIMINARY REMARKS}

This volume presents an edition and English translation of the sections of the Masoretic treatise Hidāyat al-Qāri' 'Guide for the Reader' that concern the consonants and vowels. This medieval work constitutes an important primary source for the reconstruction of the Tiberian pronunciation tradition, and it has been constantly referred to in volume 1.

Some general remarks concerning Hidāyat al-Qāri' in the context of other Masoretic treatises have been made in vol. 1, §I.0.13.1., where references are given to previous scholarship on the text, in particular the important work of Ilan Eldar.

The author of Hidāyat al-Qāri’ was the Karaite grammarian 'Abū al-Faraj Hārūn, who was active in Jerusalem in the first half of the eleventh century (see vol. 1, §I.0.13.4.). ${ }^{1}$ He produced the work in Arabic in both a long and a short version, first writing the long version and subsequently abbreviating this to produce a shortened recension. These underwent further recensions in later centuries in both Arabic and Hebrew (see vol. 1, §I.0.13.1.). The original Arabic versions written by 'Abū al-Faraj Hārūn contained an introduction, followed by sections on the consonants, vowels and accents. The edition presented in this volume is of the extant portions of the introduction and sections on the consonants and

\footnotetext{
${ }^{1}$ His authorship is identified explicitly in a scribal note preserved in the Genizah fragment of the short version JRL A 694 (Eldar 1994, 41).
} 
vowels in both versions. Also included in the edition are some selected passages from the section on the accents that relate to the gaya and to the interaction of vocalization and stress. Eldar (2018) has made an edition of the section on musical accents and also has published selected passages from other sections of both versions of the treatise (e.g. Eldar 1980; 1987a; 1987b; 1994). There are not, however, any full editions of all the extant portions of the introduction and the sections on the consonants and vowels in the two versions. Moreover, Eldar published the selected passages with a Hebrew translation. The edition in this volume, therefore, complements the work of Eldar by making available the entire text of the introduction and sections on consonants and vowels and by providing an English translation. It is based on many newly identified manuscripts in the Firkovitch collections (National Library of Russia, St. Petersburg), which now allow a complete reconstruction of the text of the short version and a nearly complete reconstruction of the text of the long version. The edition is accompanied by a commentary, which clarifies passages where it has been deemed necessary and contextualizes the ideas of 'Abū al-Faraj within the linguistic and philosophical thought of his day.

\section{II.INT.0.2. THE LONG VERSION}

In his introduction to the long version, 'Abū al-Faraj indicates (§II.L.0.1.10.) that the work consists of three discourses (maqālāt), one devoted to consonants, one to vowels and one to accents. The introduction to the third discourse refers to the 
division of the work into two parts ('ajz $\bar{a}$ '), with the first two discourses in part one and the third discourse in part two:

The first part contains two discourses. The first discourse contains a discussion concerning the letters. The second discourse contains a discussion concerning the vowels. This part contains one discourse, which contains a discussion concerning the accents of the twenty-one books and the accents of the three books. ${ }^{2}$

The majority of sections of the long version that are covered by the edition here are extant in their entirety in the surviving manuscripts, with only a few, apparently relatively small, gaps.

The grammatical works of 'Abū al-Faraj reflect a considerable influence from contemporary Arabic linguistic thought and direct parallels can be found between his works and Arabic grammatical literature (Khan 1997; Khan, Gallego, and OlszowySchlanger 2003, xi-xxxii; Becker 1996; Basal 1998; 1999). 'Abū al-Faraj's works exhibit convergences with contemporary Arabic texts also in general features of literary form, such as the authorial preface (Goldstein 2014).

The Arabic genre of literature that would be expected to correspond most closely to Hidāyat al-Qāri' is that of works on correct Qur'ānic recitation, known as tajwìd. A comparison with tajwid works from roughly the same period, such as those of

\footnotetext{
22 MS L8, fol. 57r: אן אלגזו אלאול פיה מקאלתין אלמקאלה אלאולי תשתמל עלי

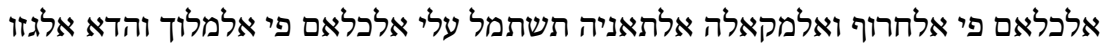

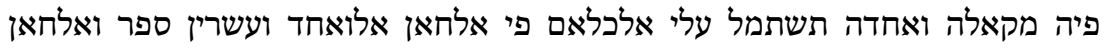
אלתלתה אספאר.
} 
al-Dānī (d. 1052-3) ${ }^{3}$ and al-Qaysī (d. 1045), ${ }^{4}$ reveals some parallels in structure. These tajwid manuals open with an introduction on the requirements of tajwid sanctioned by earlier authorities. This is followed by a series of sections on the pronunciation of the consonants, arranged by place of articulation, which is clearly analogous to the contents of the first discourse of Hidāyat al-Qāri'. In these tajwid manuals, however, there are no clear counterparts to the various sections of Hidāyat al-Qāri' on philosophical aspects of letters (§II.L.1.1.), on morphological formations involving the interchange, augmentation and elision of letters (§II.L.1.5., §II.L.1.11., §II.L.1.13.) and on verbal conjugations (§II.L.1.10), which are found in the first discourse of the long version of Hidāyat al-Qāri'.

The remainder of the contents of the tajwid manuals are concerned mainly with contextual variations in the realization of vowels, in particular with regard to their length. This does not correspond very closely to the second discourse of the long version of Hidāyat al-Qāri', which is concerned with philosophical aspects of vowels (§II.L.2.1.-§II.L.2.2., §II.L.2.18.), the role of vowels in various morphological formations (§II.L.2.3.-§II.L.2.8., §II.L.2.16.-§II.L.2.17), the shewa (§II.L.2.9.-§II.L.2.13.) and the production and places of articulation of vowels (§II.L.2.14.§II.L.2.15.).

\footnotetext{
${ }^{3}$ 'Abū 'Amr 'Uthmān ibn Sa'īd al-Dānī, Al-Tahdìd fi al-Itqān wa-l-Tajwìd (ed. al-Hamad 2001).

${ }^{4}$ Makkī ibn 'Abī Țālib al-Qaysī, Al-Ri ‘̄aya li-Tajwìd al-Qirā’a wa-Taḥqiqq Lafž al-Tìāwa (ed. Farḥāt 1996).
} 
The tajwid manuals do not contain sections corresponding to the treatment of cantillation accents in the third discourse of Hidāyat al-Qāri', since pitch variation in the recitation of the Qurān is not prescribed but is improvised (Nelson 2001).

The various aforementioned components in the three discourses of Hidāyat al-Qāri' that do not have counterparts in the tajwid manuals have been incorporated from the Masoretic tradition, from material on morphology in other grammatical works of 'Abū al-Faraj Hārūn, from the Arabic grammatical tradition, e.g. the theory of the production of vowels (§II.L.2.15.), ${ }^{5}$ and from philosophical treatments of language in Muslim speculative theological works (kalām). The custom of incorporating morphological material into treatments of pronunciation is seen already in earlier Masoretic treatises such as Kitāb al-Mușawwitāt (ed. Allony 1963) and Seder ha-Simanim (ed. Allony 1965). It is clear that Hidāyat al-Qāri' is hybrid with regard to the nature and origin of its contents. It does not replicate exactly the format of Qurānic tajwìd manuals. It does not, moreover, constitute a simple compendium of material from the Masoretic tradition, despite the statement to that effect in §II.L.0.9. of the introduction.

\section{II.INT.0.3. THE SHORT VERSION}

The short version of Hidāyat al-Qāri' has survived in many more manuscripts than the long version. This reflects the greater popularity of the short version. The same applies to the distribution of 'Abū al-Faraj's grammar book al-Kitāb al-Kāfi fi

\footnotetext{
${ }^{5}$ This can be traced to the Muslim physician Ibn Sīnā (980-1037 C.E.); cf. Eldar (1983) and vol. 1, §I.2.1.3.
} 
al-Lugha al-'Tbrāniyya 'The Sufficient Book concerning the Hebrew Language', which is a shortened version of his original grammar book al-Kitāb al-Mushtamil 'alā al-'Ușūl wa-l-Fușūl fī al-Lugha al-Ibrāniyya 'The Comprehensive Book of General Principles and Particular Rules of the Hebrew Language' and is extant in many more manuscripts than al-Kitāb al-Mushtamil (Khan, Gallego and Olszowy-Schlanger 2003, xlvii).

In the introduction to the short version of Hidāyat al-Qāri', 'Abū al-Faraj indicates that he may take the opportunity to include 'where necessary what was not mentioned in the (original) Hidāyat al-Qāri”. This is analogous to his approach in al-Kitāb al$K \bar{a} f i$, in which he in several places states that he is expanding on material that is dealt with in al-Kitāb al-Mushtamil or presenting the material in a different arrangement. In one case he admits that the view he expresses in al-Kitāb al-Kāfi should supersede the remarks he made on the subject in al-Kitāb al-Kāfi (Khan, Gallego and Olszowy-Schlanger 2003, xxxiii).

The first two discourses of the original long version of Hidāyat al-Qāri' have been made more concise in the short version by removing sections that relate to philosophical discussions of letters and vowels, and sections that are concerned with morphological patterns and processes. The main sections that are retained in the short version of the first two discourses concern the pronunciation of the consonants, vowels and shewa. The division into two discourses has also been eliminated.

The first part of the introduction to the short version (§II.S.0.1.-§II.S.0.2.) includes a variety of titles of the work. It is indicated that the long version was called Kitāb al-Shurūt 'The 
Book of Conditions/Rules', but was generally known (mulaqqab) by the name Hidāyat al-Qāri'. The term shart 'rule' is a term that is frequently used in the work. The short version of Hidāyat alQāri' (mukhtașar Hidāyat al-Qāri') is said in the introduction to have been known as Kitāb al-Muhja 'The Book of the Essential Requirements (literally: the lifeblood).' This corresponds closely the title Muhjat al-Qāri' (מהג'ה אלקאר) 'The Essential Requirements of the Reader' that appears in a booklist datable to the $13^{\text {th }}$ century (Allony 1975, 56). A Genizah fragment of the short version has a scribal note that refers to the work as Kitāb al-Hidāya fi ' Ilm Shurūt al-Miqrā 'The Book of Guidance regarding the Knowledge of the Rules of Scriptural Reading' (JRL A 694). A Genizah fragment of an anonymous Masoretic treatise (CUL T-S NS 311.113) refers, moreover, to what appears to be Hidāyat alQāri' by the title Kitāb al-'Alhān 'The Book of the Accents'.

Some other works of 'Abū al-Faraj are referred to with different forms of title. This applies, for example, to his glossary of biblical words, which is referred to in the sources with various titles, including Tafsïr 'Alfāz al-Miqrā 'Explanation of Biblical Words', Sharh 'Alfāz allatī fỉhā Șu'ūba fī al-Miqrā wa-Dhikr Ishtiqāqih $\bar{a}$ 'The Explanation of Words in the Bible that have Difficulty and the Mention of their Derivation', 'Alfäz al-Sacba allati li-l-Torah 'The Difficult Words of the Pentateuch' (Goldstein 2014, 357).

The full text of the sections that are covered in this edition are extant in the surviving manuscripts. 


\section{II.INT.0.4. THE MANUSCRIPT CORPUS}

The edition of the long version of Hidāyat al-Qāri' is based on all manuscripts of the work that are known to me. These are extant predominantly in the Second Firkovitch collection of the National Library of Russia in St. Petersburg. The corpus includes the following manuscripts. Full class-marks are given together with the abbreviations that are used in the edition: ${ }^{6}$

St. Petersburg, National Library of Russia:
II Firkovitch, Evr.-Arab. I $2390=$ L1
II Firkovitch, Evr.-Arab. I $2505=$ L2
II Firkovitch, Evr.-Arab. I $4477=$ L3
II Firkovitch, Evr.-Arab. II $307=$ L4
II Firkovitch, Evr.-Arab. II 418 = L5
II Firkovitch, Evr.-Arab. II $604=$ L6

Cambridge University Library:

$$
\text { T-S NS } 301.23=\text { L7 }
$$

New York, The Jewish Theological Seminary:

JTS 8110, EMC 829, $832=$ L8

The number of extant manuscripts of the short version is much larger and only a selection of those that are extant were

\footnotetext{
${ }^{6}$ These include some manuscripts that were identified by Ilan Eldar. I identified the remainder in my investigations in the Firkovitch collection.
} 
used for the edition. These again are predominantly from the Second Firkovitch collection, which preserves the longest manuscripts. My corpus includes the following: ${ }^{7}$

St. Petersburg, National Library of Russia:

II Firkovitch, Evr.-Arab. I $2347=$ S1

II Firkovitch, Evr.-Arab. I $2477=$ S2

II Firkovitch, Evr.-Arab. I $2478=$ S3

II Firkovitch, Evr.-Arab. I $2480=$ S4

II Firkovitch, Evr.-Arab. I $2481=$ S5

II Firkovitch, Evr.-Arab. I 2528 = S6

II Firkovitch, Evr.-Arab. I $2542=$ S7

II Firkovitch, Evr.-Arab. I $2544=$ S8

II Firkovitch, Evr.-Arab. I $2551=$ S9

II Firkovitch, Evr.-Arab. I $2557=$ S10

II Firkovitch, Evr.-Arab. I $2772=$ S11

II Firkovitch, Evr.-Arab. I $2794=$ S12

II Firkovitch, Evr.-Arab. I $2795=$ S13

II Firkovitch, Evr.-Arab. I $2813=$ S14

II Firkovitch, Evr.-Arab. I $2814=$ S15

II Firkovitch, Evr.-Arab. I $2897=$ S16

II Firkovitch, Evr.-Arab. I $2928=$ S17

II Firkovitch, Evr.-Arab. I $2941=$ S18

II Firkovitch, Evr.-Arab. I $2945=$ S19

II Firkovitch, Evr.-Arab. I 2966 = S20

${ }^{7}$ I identified the majority of these manuscripts in my searches through the Firkovitch collection. Some were drawn to my attention by José Martínez Delgado, whose help is here gratefully acknowledged. 
II Firkovitch, Evr.-Arab. I $3384=$ S 21
II Firkovitch, Evr.-Arab. I $3944=$ S 22
II Firkovitch, Evr.-Arab. II $297=$ S 23
II Firkovitch, Evr.-Arab. II $323=$ S 24
II Firkovitch, Evr.-Arab. II $325=$ S 25
II Firkovitch, Evr.-Arab. II $326=$ S 26
II Firkovitch, Evr.-Arab. II $420=$ S 27
II Firkovitch, Evr.-Arab. II $488=$ S 28

Cambridge University Library:

Mosseri I, $57.2=$ S29

In addition to these manuscripts, there are also several extant Genizah fragments containing the short version, which were used by Eldar (1987a; 1987b) in his edition of selected passages from the short version. For my own edition I decided to give preference to the longer manuscripts that are now available in the Firkovitch collection.

The manuscripts of the corpus that are used for the edition of the long and short versions are all written in Judaeo-Arabic (Arabic in Hebrew script). They do not include any colophons. Their scribal hands and codicology, however, are similar to the manuscripts from the Firkovtich collection that formed the basis of the edition of 'Abū al-Faraj's grammatical work al-Kitāb al-Kāfi (Khan, Gallego, and Olszowy-Schlanger 2003, xlvii-lxix). Based on this comparison, therefore, they can be dated to a period ranging from the eleventh to the thirteenth centuries. Their ultimate origin would in all likelihood have been the Karaite synagogue in Cairo, which appears to have been the source of most of the Second Firkovitch collection (Harviainen 1996). 


\section{II.INT.0.5. ThE EDITION AND TRANSLATION OF THE TEXTS}

The edition of the two texts follows the same basic method as was applied in the edition of 'Abū al-Faraj's al-Kitāb al-Kāfì (ed. Khan, Gallego, and Olszowy-Schlanger 2003). The objective of this method is to produce a text that is as clear and readable as possible but still remains close to the philological reality of the manuscripts.

For each section of the works a single manuscript was chosen to act as the basis of the edition. Preference was given to a manuscript that contains the section in undamaged folios. As is the case with most manuscripts of the Second Firkovitch collection, individual folios are often out of order in the manuscripts of the corpus. This has often necessitated re-ordering the folios. Where the complete section is not contained in one base manuscript, various base manuscripts are used for the section.

As far as possible, the text is presented in the edition exactly as it appears in this base manuscript for a particular section, following its orthography and reproducing the diacritical marks and vocalization. Where scribes make corrections or additions to the text, these are incorporated into the edition. No indication is made, however, of deleted text. Similarly, when text is inserted as an afterthought in the margin, it has been included in the main text of the edition .

Collations are made with other manuscripts that preserve this section of the text. Where there is a difference in another manuscript, this is indicated in the critical apparatus. These differences include both textual and also orthographic variations. 
If the reading in another manuscript is clearly superior to that of the base manuscript, the superior reading is adopted in the edited text and distinguished by enclosing it in angled brackets $\langle\ldots$.$\rangle . Editorial judgements as to superiority in reading$ do not include cases where another manuscript has a linguistic construction that conforms more closely to the conventions of Classical Arabic than the one found in the base manuscript, so long as the construction in the base manuscript could be interpreted as exhibiting a difference only in linguistic register and is not the result of a scribal error. In some cases where the reading of the base manuscript makes little sense and no superior reading is available in other manuscripts, an emended reading is proposed, enclosed in angled brackets, which is as close as possible in form to the reading in the manuscript .

If small lacunae occur in the base manuscript and the text has been supplied from another manuscript or the missing text is easily reconstructable, the supplied text is enclosed in square brackets [...].

As remarked, the diacritical marks of the base manuscript are reproduced in the edition. These include marks on letters and vocalization. In most cases diacritical dots on letters are inconsistently marked in the manuscripts and this inconsistent marking is reproduced in the edition. It was decided, however, to mark a dot consistently over the letters șade and țet when they represent Arabic $d \bar{a} d$ and $z \bar{a}$, respectively, even if they do not have a diacritical dot in the manuscript. The purpose of this was to make the text more readable. Missing or inconsistently marked diacritics of other letters were judged not to reduce the 
readability of the text. Indeed, it cannot be excluded that the omission of diacritical marks on the letters dalet and tav

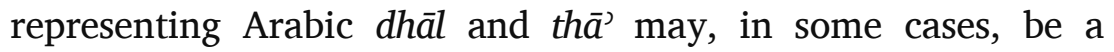
reflection of the pronunciation of these consonants by the scribe as stops rather than fricatives due to the interference of his vernacular dialect .

Hebrew words and Biblical quotations are vocalized in some manuscripts. If vocalization appears in the base manuscript, this is reproduced in the edition exactly as it is written by the scribe. The vocalization always consists of Tiberian signs, but in many cases it deviates from the standard Tiberian Masoretic vocalization. These reflect idiosyncracies of vocalization and pronunciation of individual scribes who transmitted the text. The standard Tiberian vocalization of the Hebrew words is given in the translation on the page facing the edited text. The most common deviations from standard Tiberian vocalization include the following:

Interchange of segol and patah (cf. vol. 1, §I.4.3.3.), e.g.

בֶרֶע (long version, §II.L.1.10. | Standard Tiberian: בֶּר Gen. 14.2 'Bera')

בֶּעַר : Psa. 92.7 'stupidity')

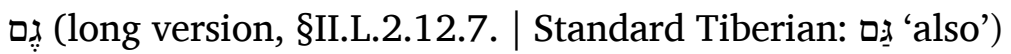

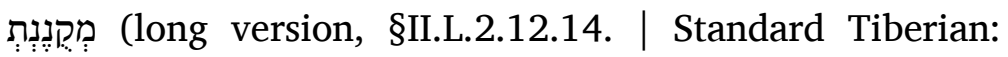

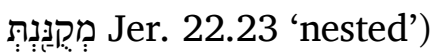

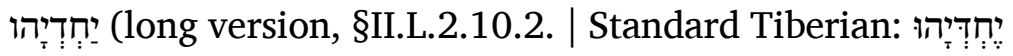
'Jehdeiah') 
ירבֵברה (long version, §II.L.1.13. | Standard Tiberian: 'it multiplies')

Simple vowel sign in place of a hațef sign on gutturals, e.g.

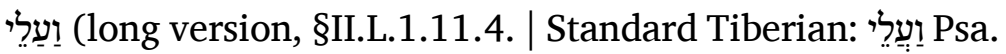
92.4 'and on')

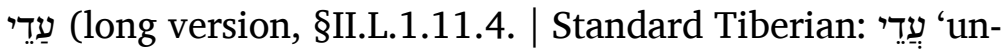
til')

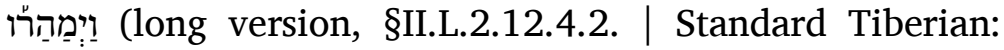

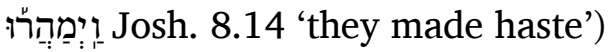

Non-standard distribution of shewa and hațef signs, e.g.

יִמְחָאוֹ כף (long version, §II.L.2.12.1.6. | Standard Tiberian:

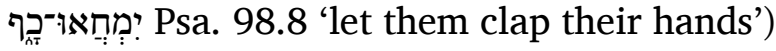

אַלָהְהוֹם (long version, §II.L.2.12.1.6. | Standard Tiberian:

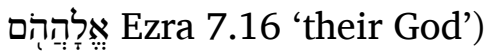

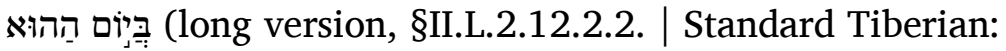
Isa. 27.2 'on that day')

The edited texts have been divided into numbered sections and subsections, which correspond to sense units. In some cases these paragraph divisions are also marked in the base manuscript by various means, such as section titles or blank spaces. In numerous cases, however, they are not marked in the manuscript. It was decided that the imposition of a system of paragraph division produced a text that is far more readable and also would facilitate reference to specific passages. The numbers of the paragraphs consist of three elements: A roman numeral II, denoting volume 2 of the book, a capital L or S, denoting the long or 
short version respectively, and a series of Arabic numerals indicating sections and subsections, e.g. II.L.1.7.11 (= vol. 2, long version, section 1.7.11.). Where the original text does not have a title at a major section division, a title indicating the contents of the section is supplied in the translation in brackets. Where the פצל fassl 'section', the specific content of the section is likewise supplied in the translation in brackets.

Section numbers of this introduction have the prefix II.Int.

The folio divisions of the base manuscript are shown in the edited text by a superscribed abbreviation of the manuscript with the folio number after a colon, indicating where the following text begins, e.g. ${ }^{\left({ }^{L 5: 17 v)}\right.}$ denotes that the following text begins on fol. 17 verso of the manuscript L5.

The English translation is intended to be read either in conjunction with the original text or independently of it. An attempt has been made to convey to the reader as clearly as possible the sense of the author. The translation is not, therefore, a slavishly literal rendering of the text, since this would often remain obscure for the English reader on account of the predilection of 'Abū al-Faraj for complex syntax. Biblical quotations are reproduced in the original Hebrew, with standard Masoretic vocalization and an English translation. Occasional footnotes clarify some details of the translation. Longer explanations on the various sections of the text are given in a commentary after the editions. This commentary includes references to various parallel sources and to the relevant sections in vol. 1. 


\section{II.INT.0.6. TERMINOLOGY}

The technical terminology used by 'Abū al-Faraj in Hidāyat alQāri' corresponds closely to what is found in his grammatical works (Khan, Gallego, and Olszowy-Schlanger 2003, xxxix-xlvi). Much of the grammatical terminology is that which was used in the mainstream Bașran school of Arabic grammar of the period. There are also a number of survivals of Hebrew and Aramaic terms from the Masoretic and early Karaite grammatical tradition. Some of these have been Arabicized. The main technical terms that are used in Hidāyat al-Qāri' are as follows.

\section{II.Int.0.6.1. Arabic Terms}

אמר 'amr 'imperative'

אנחא 'anḥā' 'vowels'

אסאס 'asās 'basic noun'

אסם ism 'noun'

הסתפהאם istifhām 'interrogative'

אצל 'aṣl 'basic form'

בי $b \bar{e}$ 'bet'

דאל dāl 'dalet'

ואו $w \bar{a} w$ 'vav'

זִ zujj 'arrow-head' (term for the vowel sign qibbus)

חרִ hִarf 'letter'

חרarf al-lin 'soft letter' (see commentary on §II.L.1.1.7.) 
חרוף harf musta'mal 'auxiliary letter' (see commentary on §II.L.1.12.3.)

טעאם tacām 'taste (of a vowel)', 'perceived quality (of a vowel)' (see commentary on §II.L.1.1.)

כאדם khādim 'subordinate particle'

כאף $k \bar{a} f$ 'kaf'

כבר khabar 'assertion'

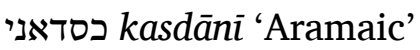

כסרה kasra (i vowel)

ذو ز khaf̣ 'lowering' (vowel quality) (see commentary on §II.L.2.3.)

לגה lugha 'lexical class' (see commentary on §II.L.0.1.1.)

māḍ̄i 'past tense'

מדגוש madgūsh 'with dagesh'

מדכר madhakkar 'masculine'

מונת mu'annath 'feminine'

מלד (powel' (literally: 'king')

mustaqbal 'future tense'

מפעול maf'ūl 'passive participle'

מפעול מטלק maf'ül mutlaq 'absolute object' (equated with the Hebrew infinitive, see commentary on §II.L.2.7.1.)

מצא mudāaf 'conjoined' (see commentary to §II.L.1.5.21.) 
mașdar musta'ār 'transposed infinitive' (see commentary on §II.L.2.7.2.)

מקטע maqta' 'prosodic stopping point', 'place of prosodic division' (§II.L.2.10.3., §I.2.5.2.)

marfï 'with rafe'

נגמה naghama 'vowel'

נצב nașb 'holding level' (vowel quality) (see commentary on §II.L.2.3.)

נקטה ואחדה nuqța wāḥida 'single dot', i.e. ḥireq

nuqta min 'asfal 'dot below', i.e. hireq

נn נקטtatayn 'two dots', i.e. șere

סאכן sākin 'silent, without a following vowel'

עבראני 'ibrānì 'Hebrew (language)'

עטף 'atf 'conjunction'

ערن 'araḍ 'abstraction, abstract property, verbal property' פאעל fä'il 'agentive participle'

פאעל באלגיר fä'il bi-l-ghayr 'transitive agent'

פאעל בנפסה fācil bi-nafsihi 'reflexive agent'

פאתחה 'patah'

פעל fi 'verb'

ficil alladhì lam yusamma fā'iluhu 'action whose agent has not been mentioned, i.e. passive. פעל פי אלנפס fil fi al-nafs 'intransitive verb' 
פar' 'secondary, derivative form'

פתחה (atha (a vowel)

צמה damma ( $u$ vowel)

(pl. 'qames’

qat ' 'disjoined state'

ראכב rākib 'affix'

רפע raf' 'raising' (vowel quality) (see commentary on §II.L.2.3.)

שוא 'shewa'

shewa mutaharrik 'mobile shewa'

שוא סאכן shewa sākin 'silent shewa'

תלת thaläth nuqaṭ 'three dots', i.e. segol

תצריף taşrif 'verbal conjugation'

תקדיר taqdìr 'virtual form' (see commentary on §II.L.1.4.8.)

\section{II.Int.0.6.2. Hebrew and Aramaic Terms}

אוֹגָרָה 'collection' of exceptional words with regard to the occurrence of dagesh on initial בגדכפת consonants (§II.L.1.7., §II.S.2.0.)

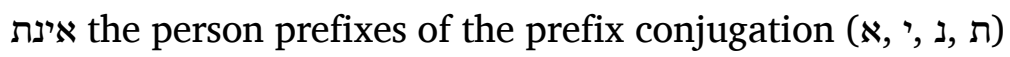

אָתֵא מֵרֵחיק 'coming from far', a variant form of dehiq (§II.L.1.7., §II.S.2.0.)

בִית הַבְּלִיעָה 'place of swallowing, throat' 
גמאל 'gimel'

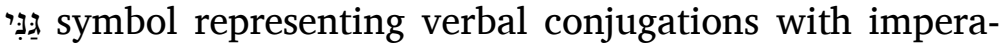
tives containing patah in the first syllable and past forms containing hireq in the first syllable (§II.L.2.7.2., §II.L.2.8.2.)

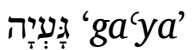

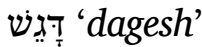

'what is compressed', dehiq, compression of a vowel that brings about the occurrence of dagesh at the beginning of a following word (§II.L.1.7., §II.S.2.0.)

"דִּפסִסיק 'what is paused', a pause due to paseq (§II.L.1.7., §II.S.2.0.)

הִי 'he’

IIT ' $v a v$ '

חית 'het'

חלִ 'holem'

חֶרֶ 'hireq'

טית' tet'

טַַע (i) 'accent'; (ii) 'taste (of a vowel)', 'perceived quality (of a vowel)' (see commentary on §II.L.1.1.)

יוד 'yod'

כּּוֹנֵ symbol representing verbal conjugations with imperatives containing holem in the first syllable and past forms containing patah in the first syllable (§II.L.2.5.) 
למאד 'lamed'

לִּשוֹ 'lexical class', 'linguistic form' (see commentary on §II.L.0.1.1.)

מִירָּע 'definite'

מאם ,מים 'mem'

מֶַּּ symbol representing verbal conjugations with imperatives containing patah in the first syllable and past forms containing segol in the first syllable (§II.L.2.7.2.)

מִכְרָת 'disjoined' (see commentary to §II.L.1.5.21.)

מְנְכָּר 'indefinite'

מֵסב symbol representing verbal conjugations with imperatives containing sere in the last syllable and past forms containing patah in the last syllable (§II.L.2.8.2.)

mappiq

נון 'nun'

סגולה 'segol'

סמאך 'samekh'

סָמוּך 'conjoined' (see commentary to §II.L.1.5.21., §II.L.2.17.)

עָבָר 'past tense'

'עין 'ayin'

עִיקָּר הַלְּשוֹן 'root of the tongue'

פא 'pe' 
פתח 'patah'

צ'sade’

צִsere'

'qof'

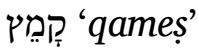

ריש 'resh'

רפָּ 'rafe'

שוּעָל symbol representing verbal conjugations with imperatives containing shureq in the first syllable and past forms containing qames in the first syllable (§II.L.2.6.)

שִין 'shin'

שִירָה symbol representing verbal conjugations with imperatives containing hireq in the first syllable and past forms containing qameș in the first syllable (§II.L.2.8.2.)

שִירו symbol representing verbal conjugations with imperatives containing hireq in the first syllable and past forms containing holem in the first syllable (§II.L.2.5.)

שרק 'shureq'

תָָּ '

תֵמַוּה 'interrogative' 


\section{HIDĀYAT AL-QĀRI'}




\title{
HIDĀYAT AL-QĀRI' (LONG VERSION)
}

\author{
II.L.0.0. (INTRODUCTION)
}

GAP

\section{II.L.0.1.}

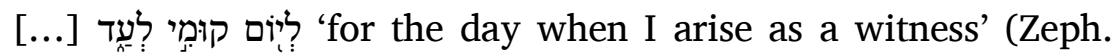

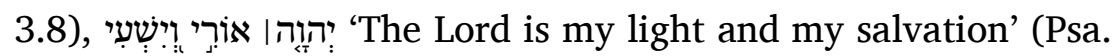
27.1), which are two masculine nouns, since the accent is at the end and not the beginning of the word. Another example is

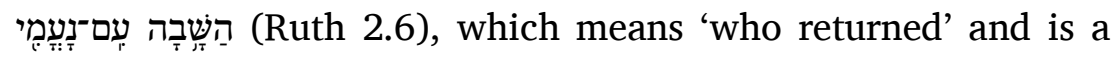
past verb, since the accent is on the first letter. Similar to this in

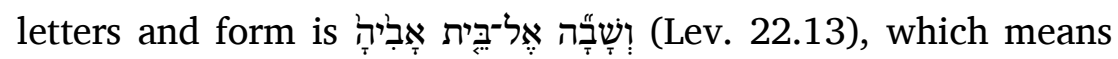
'and she became one returning (to her father's house)', 'she became one doing', since the accent is not on the first letter. A

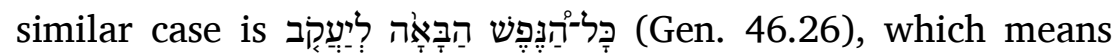
'every soul (belonging to Jacob) that is entering'. Since the accent occurs on the 'alef, (it means) the soul became one doing,

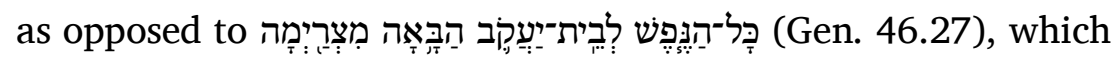
means '(all the persons belonging to Jacob who) arrived' or 'who entered'. The he in the first word (i.e. הַבָָָּ Gen. 46.26) is the he of the definite article, whereas in the second word (i.e. הַבְּאָה Gen. 46.27), it is in place of The accent has changed two things: the meaning (of the word) and the meaning of the

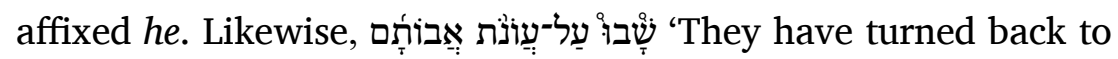
the iniquities of their forefathers' (Jer. 11.10), since the accent is on the shin, this is from the lexical class of 'returning', as

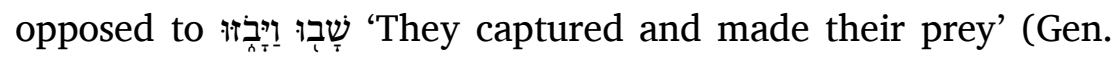
34.29), which should be interpreted as being from the lexical 


\title{
הדאיה אלקאר
}

\author{
II.L.0.0.
}

GAP

II.L.0.1.

[ ] [L:17r) למדכר למא תאכר אללחן ען אול אלכלמה וכדלך הַשְבָה עִם נָעָמֶי ותפסירה אלתי רגעת פעלא מאציא למא כאן אלטעם מע אלחרף אלאול מתל דלך פי אלחרוף ואללפט כקוֹ ושָבָָה אל בית אביה אלדי תפסירה ותציר ראגעה צארת פאעלה למא תאכר אלטעם ען אול חרף וכדלך כל הנפש הבאה ליעקב אלדי יפסר כל אלנפס אלדאכלה למגי אללחן עלי אלאלף (L5:17v) צארת אלנפס פאעלה מכאלפא לקוֹ [כל] הנפש לבית יעקב הַבְּאָה מִצְרַיְמָה אלדי תפסירה אלדי חצלת או אלדי דכלת ויכון אלהַא 10 עלי אלכלמה אלאולי הא אלתעריף ועלי אלכלמה אלתאניה מקאם אַשֶר גייר אללחן שיין אלמעני ומעני אלהא אלראכב

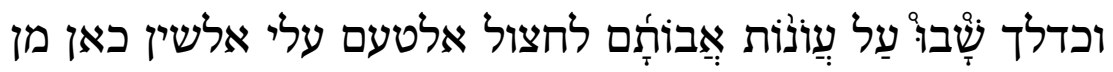
לגה אלרגוע מכאלפא שָׁבוּ וּיבזָוּ אלדי יפסר מן לגה אלסבי למגי 
עוֹרִ

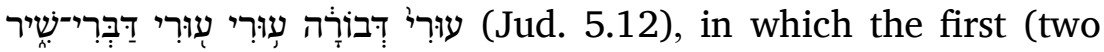

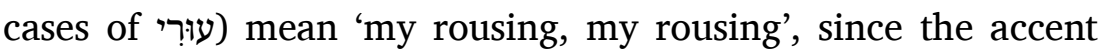
occurs on the resh, whereas the second (two cases of עוּרי) mean 'rouse yourself, rouse yourself', feminine singular imperative, on account of the occurrence of the accent on the 'ayin. Similarly,

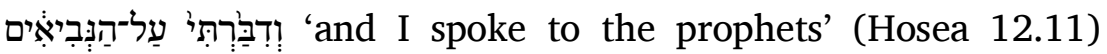
should be interpreted as a past verb, since the accent falls on the

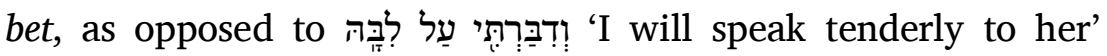
(Hosea 2.16), which should be interpreted as a future verb. (To these could be added) other similar examples. On account of this, the accents have an important status and there is a need to learn them.

\section{II.L.0.2}

If one were to say 'What do you say concerning the formation of these accents?', the response would be that they originated by convention among the people of the language, by the help of which they fully expressed their purposes, as in the aforementioned examples and others. They established them by convention, just as they established the vowels by convention, as will be explained. It is not impossible that the established form was based on a particular type of arrangement of the Levites in [ Ezra], peace be upon him, because [ ] the accents were established [ ] his time [ ], for if he investigates what [ ] the forms, he would realize that it was fixed by the Levites [ ] on the basis of the principles of singing and according to the established arrangement [ ] [ ] serves pashța [ ] close to [ ] two conjunctive accents, namely inverted shofar ${ }^{1}$ and merkha, as will be explained.

\footnotetext{
${ }^{1}$ I.e. mahpakh.
} 


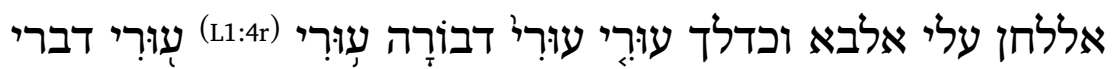
שיר אלדי תפסיר אלאול תוראני תוראני למגי אלטעם עלי

אלריש ואלذ יפסר תורי תורי אמר למונת למגי אלטעם עלי אלעין וכדלך וְדבבּרְתִי על־הַנביאים יפסר מאציא [למגי] אללחן עלי אלבא מכאלפא לקולה ודברתי על לבה אלדי יפסר מסתקבלא אלי גיר דלך ממא יגרי הדא אלמגרי פאדא כאן דלך כדלך כאן ללאלחאן מוקף כביר ואלחאגה תדעו אלי עלמהא

II.L.0.2. פאן קיל פמא [ת]קול פי הדה אלאלחאן מן רתבהא קיל לה אנהא מואצעה פי אלאצל בין אהל אללגה כמלו בע[ונהא] אגראצהם כאלאמתלה אלמדכורה וסואהא פתואצעו עליהא כמא תואצעו עלי אלמלוך עלי מא יגי ביאנה ומא ימתנע 25 אלת[ואצע] עלי וגה מכצוץ מן תרתיב אללוים פי [ [ עזרא] ע אל לאן [ ] [אלאלחאן מוצוע] [ זמאנה] [ לאן אדא תאמל מא [ ] [לאחכאם עלם אנה מן תקריר אל[לויים

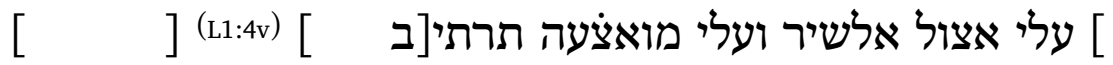
יכדם אלפשטה [ [ ] [ אלקריב אלי[ ] באדמין והמא אלשופר 30 אלמקלוב ואלמארכה עלי מא יאתי ביאנה וכדלך אלתביר 
Likewise, tevir is served by two conjunctive accents, namely merkha and darga. Each has its own special melody, and a particular number of tones in various different pitches according to the accent when it is followed by a vowel in the word, as will be explained. If it be said 'What is the origin of the melodies of the accents before the aforementioned arrangement was fixed?', the response would be as follows. It is possible that the people of the language paused on one letter and made it slightly longer than another one to the extent that they could make thereby their intentions known. My claim that the accents have been fixed since the time of the prophets, peace be upon them, is supported by three things.

\section{II.L.0.3}

One of these is that the nation has not been cut off from the holy land. The period in which they were cut off from it was between the two temples, concerning which it is stated אָז תִרְֶֶּ

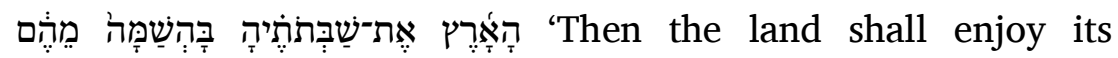
sabbaths while it lies desolate without them' (Lev. 26.34, 43). ${ }^{2}$ When the land completed its rest in the periods of its lying

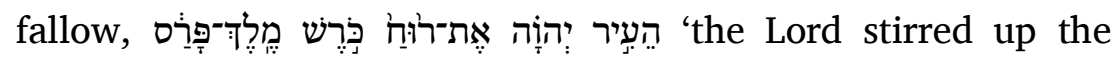
spirit of Cyrus king of Persia' (Ezra 1.1 etc.) and he sent up the two groups (of returnees) to the holy land, the group of Ezra and the group of Nehemiah, according to what [ ] Ezra. After they arrived in the Holy Land they were not cut off from it until this day. Now the reading that Ezra, peace be upon him, and his congregation used to read is the reading of the Land of Israel today. It has remained the way (of reading) that has been transmitted among them from generation to generation, from

\footnotetext{
${ }^{2}$ The wording is a conflation of the two verses Lev. 25.34 and Lev. 26.43 in the Masoretic Text.
} 
יכדמה כאדמין אלמארכה ואלסלסלה ולכל כא[ז] תנגים מכצוץ וחרכאת מעדודה עלי וגוה מכתלפה חסב >אללחן> אדא בקי בעדה מלך פי אלכלמה עלי מא יאתי ביאנה פאן קיל פכיף כאן אצל אלאלחאן פי תנאגימהא קבל אן תקרר אלתקריר אלמדכור קיל לה ימכן אן כאן אהל אללגה יוקפון אלחרף ויתקלונה ען גירה יסירא במקדאר מא יעלם בה גרצהם יאיד מא דכרתה מן אן אלאלחאן מקררה מן זמאן אלאנביא על אלס אמור ג

II.L.0.3. אחדהא אן לם תנקטע אלאמה ען ארץ הקדושה ואלמדה אלתי אנקטעו מנהא בין אלביתין והו אלדי קאל פיהא אָז תרצה הארץ את שבתותיה בהשמה מהם פלמא אסתופאת אלארץ עטלהא אלדי כאן פי אלשמטות העיר ייי [את רוח] כרש מלך פרס וצע[ד] אלגמעין אלי [ארץ הקדושה והמא ג]מע עזרא וגמע נחמיה עלי מא [ ] [זרא ומן בעד חצולהם פי ארץ [הקדוש]ה מא אנקטעו מנהא ועד היום הזה (L1:5r) פאלקראה אלדי כאן יקראהא עזרא ע א וגמע[הא] הי קראה ארץ ישראל אליום פבקית אלטריקה אלמאתורה מעהם גיל ען גיל וכלף ען כלף אלי 
one offspring to another, until now. If it be said: the wicked Edom deported the people, filled ships with them, left them without a sailor or a helmsman, and caused the hot baths to overwhelm them with smoke until they died, in accordance with what is said to have happened during the conquests of Jerusalem by Edom; the response should be: Although it did to them what you have mentioned, Edom only cut them off from Jerusalem. This is demonstrated by the fact that there was pilgrimage to Tiberias from the direction of the Levant and the East and to Gaza from the direction of the West during the period the people of Edom were in control of the Land of Israel, which was about five hundred years, in accordance with what is mentioned in their chronicles. Those who dwelt in the land all taught their children the Torah and the Scriptures, I mean the remainder of the twenty-four books. If all this is indeed so, then it must be the case that the people used to teach their children what they knew and were familiar with concerning the correct division of the accents and their musical rendition.

\section{II.L.0.4.}

The second point is that those who were exiled and did not come back with Ezra and Nehemiah, peace be upon them, remained scattered and they lost (knowledge of) the accents, and began to read with different cantillations. Therefore, you see that the (Jews of) Byzantium read in a way that is different from that of the people of Iraq. The (Jews of) Persia have a way of reading that is different from that of the (Jews of) Byzantium and the Iraqis. The people of the West have (a reading) different from all of the aforementioned. Indeed, perhaps some community that you do not know has a way (of reading) that differs from all of these, such as those whom Edom drove away to remote countries, as we have mentioned. It is the general 
אלאן פאן קיל אן אדום הרשעה אגלת אלאמה ומלת מנהם אלמראכב וכלתהא בלא נותי ולא מדבר ודכנת עליהם אלחמאמאת חתי מאתו עלי מא קיל אנה גרי פי פתוח ירושלים 50 עלי יד אדום קיל לה ואן כאן קד פעלת בהם מא דכרת פלם תקטעהם אדום אלא מן ירושלים פקט יאייד דלך אן אלחג כאן אלי טבריה מן גהה אלשאם ואלשרק ומן גהה אלגרב אלי גזה מדה מא קאמת גמאעה אדום מאלכה ארץ ישראל והו נחו כמס מאה סנה עלי מא הו מדכור פי אכבארהם ומא כאנו מקימין פי אלבלד אלא ויעלמו אולאדהם אלתורה ואלקראן אעני בקיה ארבעה וذ ספר פאדא תבתת הדה אלגמלה יצח אן אלקום כאנו יעלמו אולאדהם מא עלמוה וערפוה מן תעדיל אלאלחאן

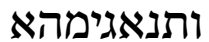

II.L.0.4. תאניהא אן אלדי אנגלא ולם יגי מע עזרא ונחמיה ע א בקיו 6 תרי אלרום יקרו בטריקה ליס הי לאהל אלעראק וללעגם טריקה ליס הי ללרום ולא ללעראקיין ולאהל אלגרב מא ליס ללמדכורין ולעל מן מא ע[רפת] (L1:5v) [לה] טריקה תכאלף אלכל וכדלך מן אגלתה אדום וצאר פי אלבלאד אלשאסעה 
consensus of those just mentioned ${ }^{3}$ that the way of reading of the Land of Israel is the original one and this is what is called the Tiberian reading. This is demonstrated by the fact that the people in the communities of the exile would press any teacher who travelled (from Tiberias) to these distant lands to teach their children the reading of the Land of Israel and eagerly imbibed that from him, making him sit down so that they could assiduously learn it from him. Whoever came from the exile to the Land of Israel had a desire for the teaching of the reading of the Land of Israel that was equally ardent as that of those absent and (a desire) for abstaining from his own (tradition of reading). This is evidence for what I have stated.

\section{II.L.0.5.}

The third point is that if somebody were to read בִּרִאטשׁׁית (Gen. 1.1) with the accent tevir or an accent other than the tifha, he would provoke the congregation to point out his error and angrily censure him. This demonstrates what I have stated. Likewise, if somebody were to read the three books with the cantillation of the twenty-one books or read the twenty-one books with the cantillation of the three books, the congregation would declare him to be in error and reject it. Likewise, if somebody were to read merkha in place of darga, or darga in place of merkha, or revia' in place of pazer, or the like, he would be declared to be in error. Now, if all this is the case, it strengthens my claim that the accents have been established since the time of the prophets. If this were not the case, then anybody who wished to change (the reading) could change it without being called to account for this, just as there would be

\footnotetext{
${ }^{3}$ I.e. the various Jewish communities outside of the Land of Israel.
} 
6 אלאצל והי אלדי יסמונהא אלקראן אלטבראני יאייד מא דכרתה אן מן סאפר מן אלמעלמין אלי הדה אלבלאד אלנאאיה עלקת בה אלגואלי ליעלם אולאדהם קראה ארץ ישראל ותנשף דלך מנה ואגלסוה ליתעלמו דלך מנה באגתהאד ומן גא מן 70 אלגולה אלי ארץ ישראל חכמה חכם אלגאיבין פי שהותה לתעלים קראה ארץ ישראל וזהדה במא פי ידה אמארה עלי מא

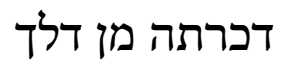
II.L.0.5. ואלג אן לו קרא אלאנסאן בראשית בלחן תביר או מא כאן מן אלאלחאן גיר אלטפחה >לכאן> פי תגליט אלגמאעה לה ואלרד עליה באלזגר דלאלה עלי מא דכרתה וכדלך לו קרי קאריא אלג אספאר בלחן אלואחד ועשרין ספר או קרי > אלואחד> ועשרין ספר בלחן אלתלתה אספאר לגלטה אלגמע ורד עליה דלך וכדי מן קרי מוצע סלסלה מארכה או מוצע מארכה סלסלה או מוצע פזר רביע ומא גרי הדה אלמגרי 80 לגלט פאדא אסתקרת הדה אלגמלה תקוא מא דכרתה מן אן אלאלחאן מקררה מן זמאן אלאנביא ולולא דלך לכאן ללמגייר (L1:6r) 
no calling to account of somebody who wanted to recite in prayer the Psalms or some passage from the twenty-four books without the intention of reading (the text) in order.

\section{II.L.0.6.}

Some people have considered the following passage to demonstrate that the accents are the work of the Levites: ושיוֹ

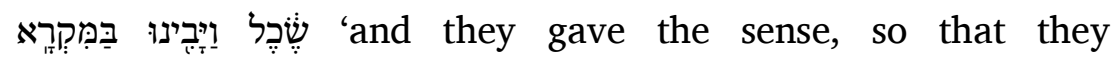
understood the reading' (Neh. 8.8). The argument is that there was no one preceding the time of Ezra, as has been mentioned before, and what is referred to (in this passage) is an innovation in relation to earlier practice. This is not improbable, since neither reason nor textual tradition confutes this claim.

\section{II.L.0.7.}

It is an established fact that the reading has various characteristic features, which the reader must learn in order to ensure a correct cantillation of what he reads. When he does not know this, the cantillation is produced in a corrupt fashion. If it be said 'So what benefit is there in the accents apart from what you have stated?', the response would be that their benefit is that they enable the congregation, however numerous, small or large, all to read one word together, and that they continue, whatever they read, in a coordinated way. Such a thing cannot be achieved without the established accents. Surely you see that Muslims, whether they be two or more, cannot read with the same degree of coordination as the Jews read, since each one has his own way (of reading). One makes long a place that another makes short. One reads melodically a place that another reads flat. For this reason they are unable to achieve what Jews do, because a group and individuals intone according to specific 
אראד אן יצלי אלתהלות > ומא כאן> מן ד וذ ספר אדא לם יכון גרنה תרתיב אלקראה

II.L.0.6.

85 וקד אסתדל בעצהם באן אלאלחאן עמל אללוים בקוֹ ושום שכל

ויבינו במקרא הדא אן לם יכון מתקדמא ען זמאן עזרא כמא דכר מן קבל ויכון מא דכר תגדיד למא תקדם ומא הו בעיד לאן לא יחיל מא דכר לא עקל ולא שרע

II.L.0.7. פקד תבת אן אלקראה להא טרק יחתאג אן יעלמהא אלקאר ליעדל תנגים מא יקראה פמתי לם יעלמה כרג אלתנגים מפסוד פאן קיל ומא פי אלאלחאן מן אלמנפעה גיר מא דכרתה קיל לה אן מנפעתהא אנה יתם ללגמע אלכתיר אלצגיר ואלכביר אן יקראו גמיעא פי כלמה ואחדה ויסתמר דלך מהמא הם יקרון עלי תרתיב ולא יתם מא הדא סבילה בגיר הדה אלאלחאן 95 אלמקררה אלי תרי אן ישמעאל לא יקדר אתנין מנהם ומא זאד יקראו עלי תרתיב מא יקרוה בני ישראל לאן לכל ואחד מנהם טריקה פהדא יתקל מוצע יכפפה גירה והדא ינגם מוצע ירסלה גירה פלהדא תעדר עליהם מא תם לבני ישראל לאן אלגמע 
rules, and they do not change that from letter to letter. If somebody were to change something, (his reading) would be rejected and declared to be incorrect.

\section{II.L.0.8.}

For this purpose and others, they fixed the rules of the accents and the masters of this discipline composed books and treatises that discuss the principles that have brought about their particular effects. They recorded what has deviated from a particular principle. This includes cases where the reason for the deviation is stated and cases where a reason is not stated. Know that the rules of the discipline of the accents involve the consideration of a particular accent that exhibits some inconsistency and stating what the reason is for this inconsistency. This involves, for example, consideration of the fact that the accent tevir is served sometimes by the conjunctive accent merkha and sometimes by darga, this being a case where the same accent has two alternating conjunctive accents. When somebody considers the reason for this, it is clear to him what the cause is that conditions the darga. The other rules are formulated in a similar manner. It is a discipline that is known by all who have investigated it carefully. If somebody has not investigated carefully, he only knows it from somebody who has investigated carefully. It is possible that the person who established these accents founded a discipline derived from them, which was transmitted with its practitioners. Some of this was lost and some remained, just as some of the knowledge of a language may be lost while some remains. This applies to the rules (of the accents). Whoever investigates carefully achieves his goal, or at least part of it. Since earlier scholars-may God have mercy 
ואלפראד ינגמו עלי אלחק בעינה ולא יגיירו דלך מן חרף אלי 100

פלהדא אלוגה וגירה צבט[ת] (L1:6v) [ש]"רוט אלאלחאן ווצעו ארבאב הדה אלעלם לה כתבא ותצאניפא יתכלמו עלי אלעלל אלתי ותרת פי מעלולאתהא וצבטו מא כרג ען תיך אלעלה פמנהא מא דכר אלסבב פי כרוגה ומנהא מא לם ידכר לה סבבא ואעלם אן אלשרוט פי עלמהא תחתאג אן ינטר לחן ואחד 105 יכון פיה כלאף מא פיקול אלנאטר מא אלסבב פי הדא אלכלאף כמן נטר פי לחן תביר אנה יכדמה תארה מארכה ותארה סלסלה והו לחן ואחד ואלכאדמין מתגאיראן פאדא נטר מא אלסבב פי דלך באן לה מא > אלעלה> אלמוגבה ללסלסלה וכדי יגרי אמר סאיר אלשרוט פהו עלם יעלמה כל מן נטר פיה באלסבר ואן לם יסבר לם יעלם אלא ממן סבר ומא ימתנע אן יכון אלואצע להדה אלאלחאן געל להא עלמא מסתמדא וכאן מע אצחאבה ואנדרס מנה אלבעץ ובקי אלבעץ כמא אנדרס מא כאן מעלום מן בעץ אללגה ובקי אלבעץ וכדלך אלשרוט פמן רגע אלי אלסבר חצל לה אלגרץ או בעצה למא כאן אלמתקדמין 
upon them-investigated this discipline very carefully, they achieved an expert knowledge of it.

\section{II.L.0.9.}

When, however, somebody wishes to learn about this, he is not able to find a complete book of theirs on this subject, only fragmentary writings. I have, therefore, been requested to strive to complete this short treatise that I have begun, and I have acceded to this request, acknowledging my deficiencies with regard to it and transmitting what I have learnt from their writings and from their pupils, and seeking help (in this task) from the God of Israel.

\section{II.L.0.10.}

This book consists of three sections. The first section concerns the letters and their pivots, I mean their places (of articulation) in the mouth, including those that are heavy and those that are light. The second section concerns the vowels, those that are long and those that are short, their places of articulation, their basic form and their accidental properties. The third section concerns the accents, those of low pitch and those of high pitch, and their subordinate accents. 
רח אללה קד סבר הדא אלעלם סברא גיידא אתבתו מא עלמוה

$$
\text { II.L.0.9. }
$$

ולמא ראם אלראים עלם דלך לם יציב להם פי דלך כתאבא כאמלא בל כתב מקטעה פסאל אלסאיל אן אגד פי מא אבתדית בה מן תכמיל הדא אלמכתצר פאגבת אלי דלך מקר בקצורי פיה חאכי מא תעלמתה מן כתבהם ומן (L1:7r) תלאמידהם

ובאלהי ישראל אסתעין

II.L.0.10.

הדא אלכתאב ישתמל עלי תלת מקאלאת אלמקאלה אלא פי אלחרוף ומראכזהא אעני מחאלהא פי אלפם ואלתקיל מנהא ואלכפיף אלמקאלה אלذ פי אלמלוך ותקילהא וכפיפהא ומחאלהא ואסהא >וערצהא> אלמקאלה אלג פי אלאלחאן

ווצעהא ורפעהא וכדאמהא

125 וערצהא] וערצעהא L1 


\section{II.L.1.0. \\ THE FIRST DISCOURSE: ON THE LETTERS}

\section{II.L.1.1. (Preliminary Discussion concerning the Nature of Letters)}

\section{II.L.1.1.1.}

It should be noted that a letter by itself in isolation does not convey meaning. What we say is demonstrated by the fact that if you say אלף ('alef), although you may think it is a single letter, it is not one but three letters, viz. א ל פ. Likewise, the (b) bet) is two letters. Similarly, when you say גמאל (gimel), this is four letters. Similarly, the דאל (dāl, i.e. dalet) is three letters, and so forth for the remainder of the inventory of letters. This is because one cannot communicate only with the (phonetic) property of the letter itself, but when two letters follow each other, it is possible to do this with them, whether they are identical or different, as when you say ('ָּ⿱

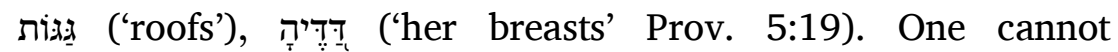
communicate concerning the (phonetic) property of gimel or the (phonetic) property of $d \bar{a} l$ (i.e. dalet) (by uttering the sounds) in isolation. This shows that the original conventional agreement was on the properties of the letters, and since the property could not be talked about (by uttering it) by itself, it needed something else to allow it to stand as an independent expression

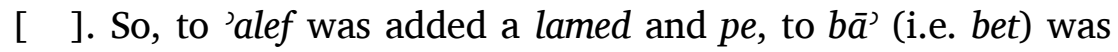
added an 'alef, and to gimel mem, 'alef and lamed so that it is possible to communicate about their property in isolation.

\section{II.L.1.1.2.}

If somebody were to say 'Why was the conventional agreement not on the 'alef without its property, and on the $b \bar{a}$ ' (i.e. bet) and gimel without their property', the response would be that 'alef 


\section{II.L. 1.0. \\ אלמקאלה אלאולי אלכלאם פי אלחרוף}

II.L. 1.1.

II.L.1.1.1.

אעלם אן אלחרף וחדה לא יפיד במגרדה יביין מא קולנא אן

קולך אלף ואן כאן ענדך אנה חרף ואחד פליס הו ואחד בל ذ חרוף אלף וכדלך אלבא איצא חרפאן וכדלך קולך גמאל ד' חרוף וכדלך אלדאל ذ חרוף ועלי הדא אלמגרי יגרי אמר בקיה אלקבאלה ודלך אן מחץ אלחרף וטעמה לא יצח אלתכאטב במפרדה בל אדא תראדפא צח דלך פיהמא מתלין כאנא או

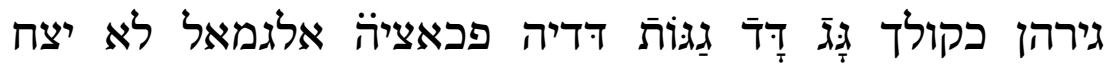
אלתכאטב בהא ולא כאציה אלדאל עלי אלתפריד פדל דלך עלי אן אצל אלמואצעה עלי כואץ אלחרוף ולמא לם תכון אלכאציה תנהץ בנפסהא פי אלתכאטב אחתאגת אלי אמר אכר יקלהא וינהצהא [ ] ] דלך פאזיד עלי אלאלף למאד ופא ואזיד עלי [אלבא] אלף עלי אלגמאל מאם ואלף ולמאד חתי יצח אל]תכאטב] (L1:7v) באלכאציה עלי אלתפריד

II.L.1.1.2

פאן קאל קאיל פלם לא כאן אלתואצע עלי אלאלף דון כאציתה ואלבא ואלגמאל דון כאציתהמא קיל לה אן אלאלף פיה ג חרוף 
has three letters and each letter has a different property, so how could they aim to know the property of one letter, then two further letters when no property is known to them. Rather it is necessary for them to know the distinctive property of the three letters and then pronounce a single word. My claim that the conventional agreement was initially on the property of the letter is supported by the fact that people differ with regard to the number of the letters that are added to the quality of the letter and its phonetic property, whereas no difference is permitted with regard to the quality of the letter and its phonetic property. This is because the Tiberians add only yod to the essence of $b \bar{a}^{\text {, }}$, whereas other towns add to it yod and tav and they say 'bet'. Likewise, they (the Tiberians) add 'alef and lamed to the property of $d \bar{a} l$, whereas others add lamed and tav and say 'dalet'. They add 'alef and yod to the quality of $z \bar{a} y$ and say ' $z \bar{a} y$ ', whereas others add nun to this and say 'zayin'. To lamād they add mem, then 'alef, then $d \bar{a}$, where others reverse this and add 'alef, then mem, then dāl and say 'lamed', and so forth. This is also the practice with the remaining letters. The variation has not taken place in the property (of the letter) but rather in the occurrence of the added letters in order for the property to be articulated in a single utterance. If this (i.e. the addition of letters) is what existed in the establishment (of the language), there would be no variation.

\section{II.L.1.1.3.}

Since the property of the letter requires other (elements), the additions have been added to the property and the letter has become a free-standing entity consisting of a combination of its property with additional elements. After this, however, the 
ולכל חרף כאציה מתגאירה פכיף יקצדו כאציה חרף ואחד ותם חרפאן מא ערף להם כאציה ואנמא ינבגי אן יערפו כצוציה אלתלת חרוף תם ינטקו בהא כלמה ואחדה יאייד מא דכרתה מן אן אלמואצעה וקעת עלי כאציה אלחרף פי אלאבתדא הו אן אלחרוף אלמצאפה אלי טעם אלחרף וכאציתה קד יכתלף אלנאס פי כתרתהא וקלתהא וטעם אלחרף וכאציתה לא יצח בתה אלכרוג ענה ודלך אן אלטבראניין יזידון עלי כאציה אלבא יוד פקט ומדן אכר יזידון עליה יוד ותָזו פיקולון בית וכדלך יזידון עלי כאציה אלדאל אלף ולמאד וגירהם יזיד למאד ותו פיקולון דלת וכדלך יזידון עלי טעם אלזאי אלף ויוד פיקולון זאי וגירהם יזיד עלי דלך נון פיקולון זאין וכדלך אללמאד יזידון עליה מאם תם אלף תם דאל וגירהם יעכס דלך פיזיד אלף תם מאם תם דאל פיקול לאמד אלי גיר דלך ומא גרי הדה אלמגרי פי בקיה אלחרוף פאלתגייר לם יקע [פי אל]כאציה בל >פי וקוע> אלחרוף אלמזידה >לנהוץ>> [אלכא]ציה באללפט פי אלתפריד פלו כאן ממא הו [וקע] פי אלמואצעה לם יתגייר

II.L.1.1.3. פלמא אפתקרת (L1:8r) אלכאציה אלי גירה זידת אלזואיד עלי

160 אלכאציה ואסתקל אלחרף בטעמה מע אלזואיד ולם יכן מן בעד 
letter still cannot communicate meaning by itself, because if somebody said 'alef', he would not thereby communicate to the hearer more than what he already knows, namely that 'alef is distinct from (other letters such as) tet. The letter, therefore, requires other letters to be combined with it in order for meanings to be understood. So it is required, for example, to have the combination 'alef, resh and șade to (form the word) ארץ, and the combination shin, mem and resh to form שמר.

\section{II.L.1.1.4.}

Just as the property of a letter requires added elements, the combinations of letters required something else, without which no meaning can be understood by the joining of letters, namely the vowels (literally: 'kings'), which are called also vocalization (literally: inflectional vowels). This is because if (vowels such as) qames and patah were missing from שמר, you would not know to what form to assign the word, whether to שֶׁ, or to ששוֹמֶר or. This would have been after the vowels were fixed among those who established (the language) by convention. If the vowels are removed, the meaning is not understood at all.

\section{II.L.1.1.5.}

The letters and vowels also require something else, namely the accents. This is the case as remarked above with (a pair of) words that have identical combinations of letters and identical vowels with no difference (between them), and that require (the placement of) the accent in order for the meaning to be

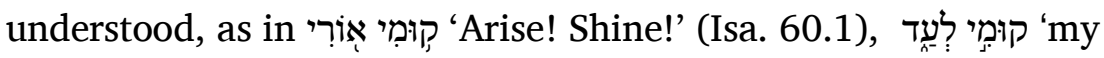

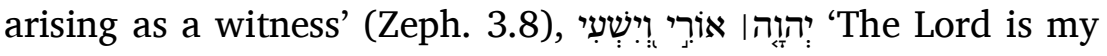
light and salvation' (Psa. 27.1). 
דלך אלחרף יפיד מעני במפרדה לאן לו קאל קאיל אלף למא אפאד אלסאמע מנה גיר מא עלמה אנה אלף מכאלף לטית פאחתאג אלחרף איצא אלי גירה מן אלחרוף ינטם אליה ליפהם בדלך אלמעאני פאחתיג אלי אלאלף ואלריש ואלצדי פי ארץ ואלי אלשין ואלמים ואלריש פי שמר

II.L.1.1.4. וכמא אפתקרת כאציה אלחרף אלי אלזואיד אפתקרת אלחרוף אלמנצומה אלי אמר אכר לולאה מא פהם באנצמאם אלחרוף מעני והם אלמלוך אלדי תסמא אנחא >לאן> לו עדם מן שמר אלקאמצה ואלפאתחה למא עלמת אלי אין תרדהא אלי שָמוֹר אם אלי שְממר אם אלי שוֹמֵר הדא בעד אסתקראר אלמלוך בין אלמתואצעין ואמא בארתפאע אלמלוך מא יפהם מעני אלבתה

II.L.1.1.5. ואפתקר איצא אלחרוף ואלמלוך אלי אמר אכר והו אלאלחאן כמא מצא פימא אנצמת חרופה עלי סוא ואסתות מלוכה מן גיר כלף ואחתאג אלי אללחן ליפהם אלמעני מתל קְומִי אָו[רי] קוּמִי לעד ייי אוֹבְי וישעי 


\section{II.L.1.1.6.}

So, there are four cases of need (of complements): the need of the property (of a letter) for added elements in order for it to be an autonomous utterance, the need of a letter for another letter, the need of (a combination of) letters for vowels-these three are necessarily interdependent-and the need of (combinations of) letters and vowels for accents, not in all circumstances but in certain cases. For this reason I have presented the section on letters first, then I have presented second the section on vowels and I have presented third the section on accents, according to this order of obligatory complementarity.

\section{II.L.1.1.7.}

Now, meaning is not expressed by a letter alone and so the Hebrew grammarians have called a 'letter particle' a 'functional particle', since a functional particle does not express meaning in relation to itself but expresses meaning in relation to something else. This terminology (i.e. 'functional particle' rather than 'letter') is appropriate because אֶל consists of two letters, and

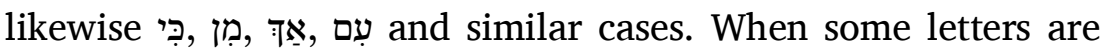
combined with each other, unwritten letters are concealed between written letters. The main case of this are the vowels in words such as שָָׁם 'alef is hidden, which is one of the soft letters. When some letters are combined and a vowel occurs with them, a letter is not hidden between them, as in פִִּ , מִּ , in which another letter is not hidden between the two (written) letters, as a yod is

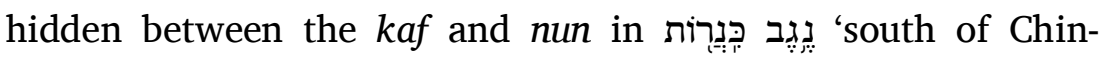
neroth' (Josh. 11.2). There are many cases of this, but I have cited here one example. 
II.L.1.1.6.

פצאר ארבעה אפתקאראת אפתקאר אלכאציה אלי אלזואיד

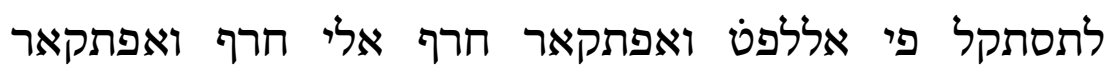
אלחרוף אלי אלמלוך הדה תלתה לא בד מן חאגה בעצהא אלי בעץ ואפתקאר אלחרונף] (L1:8v) ואלמלוך אלי אלאלחאן לא עלי 180

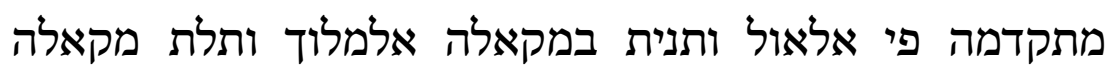
אלאלחאן עלי תרתיב אלאפתקאר ואלחאגה מתור וחנית

II.L.1.1.7. פאדן אלחרף וחדה לא יפאד מנה מעני ועלי הדא אלוגה סמא אלדקדוקיין >אלחרף כאדמא> מן חית אן אלכאדם וחדה לא יפיד מעני פי נפסה בל יפיד מעני פי גירה והדה אלתסמיה תגוז 185

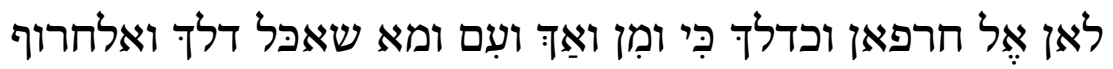
פיהא מא אדא אנצם בעצהא אלי בעץ אנכתמת חרוף גיר מכתובה בין אלחרוף אלמכתובה ואלאצל פי דלך אלמלוך כקולך שָם בם עם יד שם פקד אנכתם פי כל לפטה חרף אלף 190 מלך לא ינכתם בינהמא חרף כק כִי בוֹ מִי בִי אלדי מא כפי בין

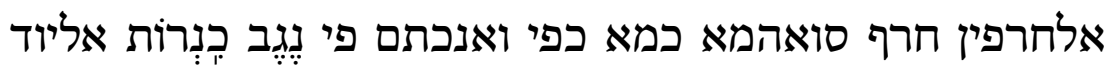
בין אלכאף ואלנון ואמתאל דלך כתיר ואנמא אורדת באנמודגא 


\section{II.L.1.2. Section (concerning the Inventory of Letters)}

The traditional inventory of letters consists of twenty-two basic letters. To the basic letters are added five letters, which are called 'straight', namely דסוףץ. To the basic letters are added six letters, namely בגדכפת. The Tiberians add to these six letters the letter resh, making it (i.e. the group of non-basic letters) בגדכפרת, so that the total comes to thirty-four with the resh of the Tiberians. It is said that there are some who attribute a particular feature to zayin and call it zāy makrūkh. I have not, however, been able to identify their purpose in using the term makrūkh, in order for me to be able to describe it, as I shall describe the purpose of the Tiberians (in the use of this term makrūkh) with regard to the resh.

\section{II.L.1.3. Chapter concerning the Place (of Articulation) of the Letters}

\section{II.L.1.3.1.}

Know that according to the traditional inventory (of letters) there are five groups in five places (of articulation). These are בומף, זסצש, דטלנת, גיכרק, אהחע.

\section{II.L.1.3.2.}

The letters אהחע have a single place of articulation. This is the throat and the root of the tongue. The Tiberians call it the 'root of the tongue' and the 'place of swallowing'. This is the first place of articulation in the mouth. For this reason they are the lightest letters, as a group or individually. The meaning of their 'lightness' is that they never take dagesh. It has been said that dagesh is placed in 'alef in some specific places in Scripture,

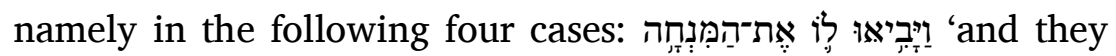

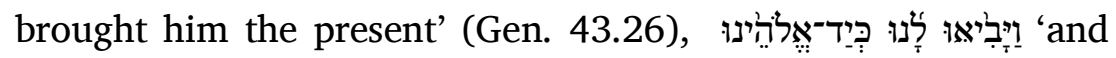
they brought to us by the hand of our God' (Ezra

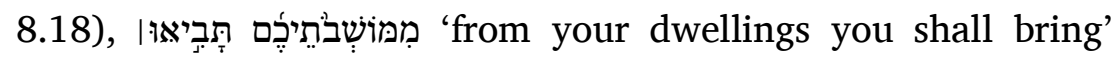


פצל II.L.1.2.

אלקבלה ذב חרף אצולא וינצאף אלי אלאצול כמסה חרוף והי פצל

אלתי יסמונהא פשוטות והם خَذוֹףنץ ינצאף אלי אלאצול איצא סתה חרוף והי ב̇גֹذذפת אלטבראניין יזידו עלי הדה אלסתה אחרף חרף ריש ויגעלונהא ב̇גדذذפרּ פיציר אלכל ארבעה (L1:9r) ותלאתין בריש אלטבראניין וקד קיל אן תם מן יגעל ללזאי חכם 200 פכנת אדכרה כמא אדכר גרن אלטבראניין פי אלריש II.L.1.3.

II.L.1.3.1. אעלם אלקבלה תגי כמסה אקסאם פי כמסה מחאל והי אהזחע

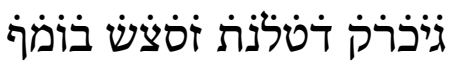

II.L.1.3.2. אהֹזע מחלהא מחל ואחד והו אלחלקום ואצל אללסאן ויסמונה אלטבראניין עקר הלשון ובית הבליעה והו אול מחל פי אלפם ולדלך צארת אכף אלחרוף מגמועה או מפתרקה ומעני אלכפה פיהא הו אן לא ידכלהא דגש בתה וקד קיל אן אלדגש ידכל פי אלאלף פי מואצע מכצוצה מן אלמקרא והו ארבעה וּיביאו לו את המנחה ויביאו לנו כיד אלהינו ממשבותיכם תביאו ושפו 


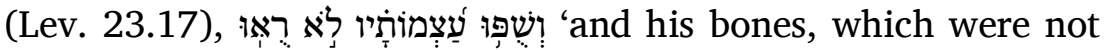
seen, are laid bare' (Job 33.21). I shall clarify this in response to those who have adduced this as a counterargument. Het and 'ayin do not take dagesh in any circumstances. As for he, it takes what could be thought to be dagesh, but it is not what it is thought to be. This is because dagesh makes a letter heavy and rafe makes it soft, as in 'roof'.

\section{II.L.1.3.3.}

The quality of the letter is uttered with dagesh and with rafe in the realization of its phonetic property. Dagesh is placed on a letter at the beginning of a word, the middle and the end. This is not the case with he, since it is in a place (of articulation) in which heaviness is not possible. This is because heaviness is for the purpose of a pressure ${ }^{4}$ that is applied to the place of articulation, so that the letter is made heavy. The tongue root and the place of swallowing are not a place that permits closure or contraction, or what resembles this, like the lips, which can be closed and receive pressure, ${ }^{5}$ so that from them can be heard בִי a a a a will be described below. It is only at the end of a word that a point occurs in it (i.e. he) in order to cause its property to appear and distinguish it from places where it does

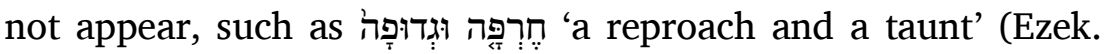
5.15), in which the quality of the he is not pronounced, rather it is pronounced with the pronunciation of 'alef. This differs from the other letters in which dagesh is permitted, such as kaf and pe, which have two types of pronunciation that both necessarily entail the articulation of the property of the letter.

\footnotetext{
${ }^{4}$ Literally: leaning. $\mid{ }^{5}$ Literally: leaned upon.
} 
עצמותיו לא ראו וסאביין אלכלאם פיה פי גואב מן עארץ בה ואלחית ואלעין פלא ידכלהא דגש לא בוגה ולא בסבב ואלהא קד ידכלה בטן אלטאן אנה דגש וליס דלך כמא טן לאן אלדגש יתקל אלחרף ואלרפי ירכיה כק גָּَ

II.L.1.3.3. קד כרג טעם אלחרף פי אלדגש ואלרפי למעני כאציתה ואלדגש ידכל פי אלחרף פי אול אלכלאם ואלוצט ואלאכר ואלהא מא הדא חאלה לאנה פי מחל לא יצח פיה אלתקל לאן אלתקל ללאעתמאד יפעל פי אלמחל פיתקל דלך אלחרף ועקר הלשון ובית הבליעה מא המא מחל יגוז פיה אלטבק או אלצם או (L1:9v) מא מאתל דלך כאלשפתין אלתי יצח אן תטבקא ויעתמד עליהא ויסמע מנהא בִּי ובבי עלי מא ידכר מן בעד ואנמא יגי פי אואכר אלכלאם פקט פיה נקטה פתצהר כאציתה ותבינה פי מא לא

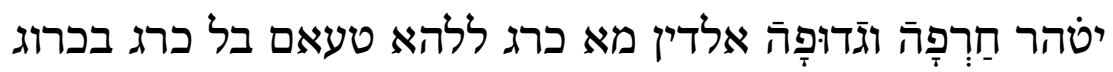
אלאלף אלדי הו מכאלף לבקיה אלחרוף אלדי יצח פיהמא אלדגש כאלכאף ואלפא אלדי עלי חאלתין פי אלנטק לא בד מן אללפט פי כאציה אלחרף 


\section{II.L.1.3.4.}

As for he, this is not pronounced at the end of a word unless it has a dot in it. This is is not called dagesh but rather 'appearance'. Do you not see that if a dot appears in it, (it is) at

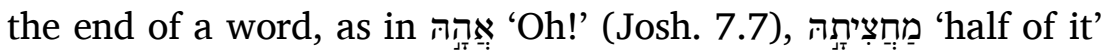
(Lev. 6.13). It may occur in the middle of a word and be pronounced in the way that it is pronounced when it has a dot

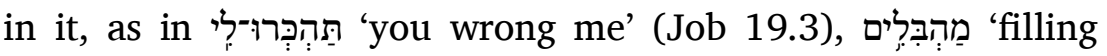

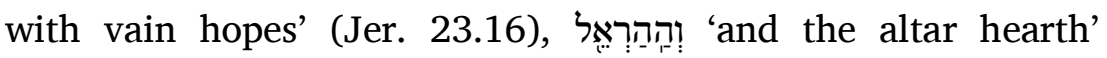
(Ezek. 43.15). So it is clear to you that this (dot) denotes appearance and is not dagesh, for dagesh is a strengthening that occurs in the letter after the articulation of its property: מֶלֶּ

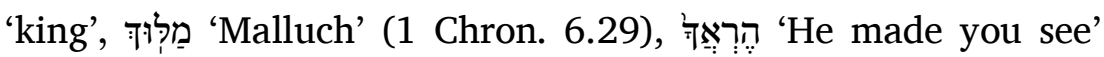
(Deut. 4.36), הַרְִִּיתֶם 'Have you seen?' (1 Sam. 10.24). It is clear, therefore, from this that the dot in $h e$ is to indicate the appearance of the property (of the letter) and not for making it heavy.

\section{II.L.1.3.5.}

It follows from all of this that these four letters are never made heavy since they are in the first place of articulation from which speech is sounded. If it were said: Surely the dagesh may be inserted in some of the four letters of this place, namely in the 'alef in the four passages that you have just mentioned, and this disproves your statement that dagesh is not put on the letters of this place of articulation, the response would be: If one examines carefully the so-called dagesh in the 'alef in these four passages, one sees that it is not dagesh, since the speaker strives 
II.L.1.3.4.

ואלהא לא ילפט בה פי אכר אללפט אלא אן יכון פיה נקטה פלא יסמא הדא דגש בל טהור אלי תרי אנה אדא חצל פיה אלנקטה פי אכר אלכלמה כק אֲהָהּ מַחַצִיתָהּ וקד יכון פי וצט אלכלאם מן גיר הדא אלנקטה וילפט בה עלי מא ילפט בה ופיה

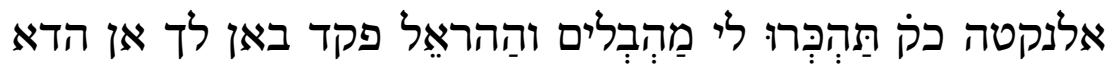
טהור לא דגש לאן אלדגש הו תשדיד יחצל פי אלחרף בעד >אלנטק> בכאציתה כק מֶלֶּף מלוך הַרְאָּ הַרּאיתם פבאן בדלך אן אלנקטה פי אלהא אנמא הי לטהור אלכאציה לא ללתתקיל

II.L.1.3.5. פחצל מן הדה אלגמלה אן הדה אלד חרוף לא תתקל בתה למא

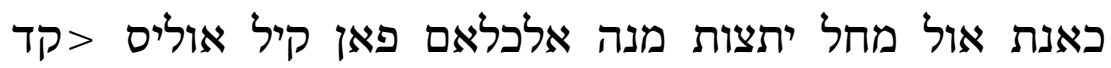

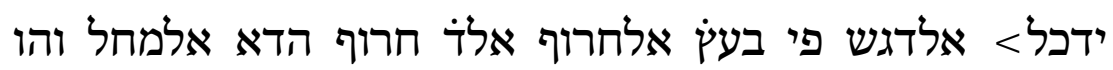

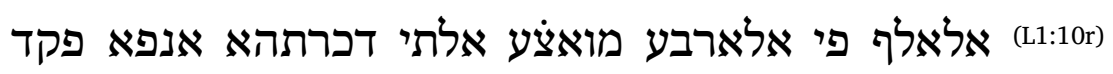

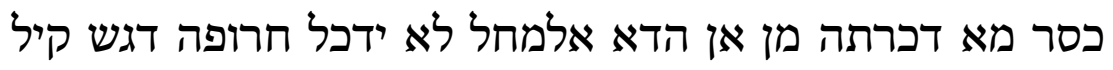

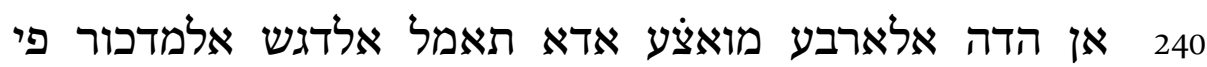

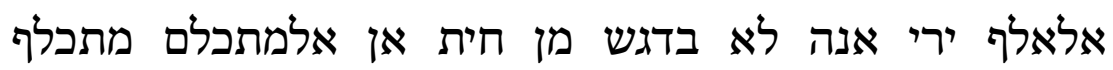


to introduce heaviness into it but it is not made heavy. Surely you see how heaviness occurs in bet, kaf and other letters without effort and strengthening takes place. This is not the case with 'alef. If one examines carefully whether 'alef is made heavy in this way, one will see that it is not made heavy. Rather it is as if the speaker is taking it out of a pit, unlike the other letters in which dagesh is permitted. It is said that the reason for the impossibility of heaviness in the letters of this place of articulation is that it is the first of the places of articulation, and the more the articulation progresses upwards from place to place, the more heaviness can be applied.

\section{II.L.1.3.6.}

From the second of the places of articulation are heard $\bar{\lambda}$ and $\overline{\bar{T}}$ rafe. This is the third of the tongue that is adjacent to the pharynx, opposite the (soft) palate. In fact this is not a primary place of articulation, but it functions like one. This is because when gimel and kaf have dagesh, their place of articulation is the middle of the tongue, in its wide part. The primary places of articulation are five in number. The third of the tongue that is the place of articulation of the two (aforementioned) letters with rafe, I mean $\bar{\lambda}$ and $\overline{\bar{\eta}}$, is secondary. So, the total number of places of articulation are six, five primary and one secondary. The middle of the tongue is the place of articulation of five letters, namely גיכרק.

\section{II.L.1.3.7.}

From the third place of articulation are heard five letters, namely דטלנת. This is the extremity of the tongue in combination with the flesh of the teeth. If you press gently, you hear from it $\overline{\bar{\tau}}$ and $\overline{\boldsymbol{s}}$ rafe. If you press with force, you hear from it $\bar{T}$ 
לאדכאל אלתתקיל פיה והו לא יתקל אלי תרי כיף יגי אלתתקיל פי אלבי ואלכאף וגירהמא בגיר תכלף ויקע אלתשדיד מוקעה וליס כדלך אלאלף ואן תאמל דלך פי תתקיל אלאלף עלם אנה לא יתקל ואנמא אלמתכלם כאנה יכרגה מן גב מכאלפא למא יצח פיה אלדגש מן סאיר אלחרוף וקיל אן אלעלה פי סקוט אלתתקיל ען חרוף הדא אלמחל לאנה אול אלמחאל וכל מא צעד מן מחל אלי מחל יתקל

II.L.1.3.6. ואלמחל אלתאני מן מחאל אלחרוף יסמע מנה ג' † אלמרפיין והו תלת אללסאן ממא ילי אלחלקום קדאם אלחנך והדא אלמחל ליס הו אלאצל פי אלחקיקה בל יגרי מגראה לאן מתי צאר אלגמאל ואלכאף מדגושה כאן מחלהמא וסט אללסאן בערצה פאצול אלמחאל כמסה ותלת אללסאן אלדי הו מחל אלחרפין אלמרפיין אעני ג † הוא פר[ע] פגמלה אלמחאל סתה כמסה אצול וואח[ד] (L1:10v) פרע פוסט אללסאן מחל לכמסה חרוף והי גְּכרוק

II.L.1.3.7. ואלמחל אלתאלת >יסמע מנה> כמסה חרוף והי דंטלנת והו טרף אללסאן מע לחם אלאסנאן ואן אלצקת ברפק סמעת

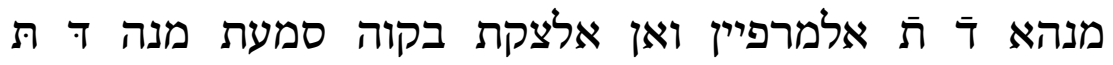


and s with dagesh. This differs from the second place of articulation, which is divided into two places (when the letters are pronounced) with dagesh and rafe respectively, namely the (back) third of the tongue and its middle. Dalet and tav are not like that, rather their place of articulation does not change, whether they have dagesh or rafe. Dagesh denotes pressing with force and rafe (pressing) lightly.

\section{II.L.1.3.8.}

The fourth place of articulation is the teeth, from which are heard four letters, namely rסצש. In this place of articulation the letters are not divided into light and heavy as in the preceding places of articulation. Know that when you pronounce (the word) שִין, you pronounce three letters from three different places of articulation, the shin from the teeth, the yod from the middle of the tongue, in its wide part, and the nun from the extremity of the tongue and the flesh of the teeth. If you taste a letter (by pronouncing it) in its place of articulation, you will taste its property.

\section{II.L.1.3.9.}

The fifth place of articulation is the lips, which is that of the four letters בומף. If you close the lips with force, $\exists$ and $₫$ with dagesh are heard. If you close them gently and lightly, you hear from them $\bar{\Sigma}$ and $\bar{\eta}$ with rafe. This place of articulation is like the place of articulation of דטלנת, where two letters with dagesh and two letters with rafe are heard. 
אלמדגושין והדא מכאלף ללמחל אלב אלדי אנקסם אלי מחלין ענד אלדגש ואלרפה המא תלת אללסאן ווסטה ואלדאל ואלתו ליס המא כדלך בל מחלהמא לא יתגייר לא פי אלדגש ולא פי אלרפי ואנמא אלדגש לאלאלצאק באלקוה ואלרפי באלכפה

II.L.1.3.8. ואלמחל אלראבע הו >אלאסנאן> יסמע מנה דं חרוף והי זֹסצنש והדא אלמחל לא ינקסם פיה אלחרף אלי כפה ותקל מתל אלמחאל אלדי תקדמתה ואעלם אנך אדא לפטת בשין פקד לפטת בג חרוף מן תלת מחאל מתגאירה פאלשין מן אלאסנאן ואליוד מן [וסט] אללסאן בערצה ואלנון מן טרף אללסאן ולחם אלאסנאן פאדא דקת אלחרף פי מחלה אנמא דקת מנה כאציתה

II.L.1.3.9. ואלמחל אלה הו אלשפתין מחל ארבע חרוף בוֹמוף פאן אטבק[ת] אלשפתין בקוה סמע מנהמא (L1:11r) בּ פּ אלוף אלמדגושין

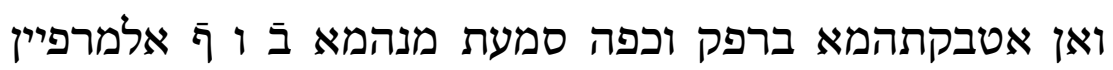

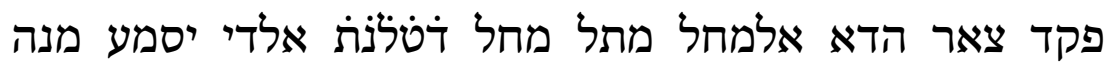
חרפין מדגושין וחרפין מרפיין 


\section{II.L.1.4. Section (concerning some General Issues relating to Letters)}

\section{II.L.1.4.1.}

If somebody were to say 'What is the value of knowing the places of articulation of the letters?', the response to him would be as follows. If somebody asked and said 'What is language?', I would say: It consists of expressions that its original speakers ${ }^{6}$ established by convention among themselves to make their intentions understood to one another. It needs to be known that before this they established by convention specific letters in various places of articulation, from which the expressions could be constructed. They were, therefore, the foundations of the expressions. Through knowledge of the places of articulation the thinking of the establishers (of the language) can become clear, in that they taught that the meaning that one intends can be fully expressed with twenty-two letters, but cannot be fully expressed with less than this. They took them from five basic places of articulation, and one secondary place of articulation, as has been explained. Either it was the case that only the aforementioned letters could have been produced from each place of articulation or they knew that letters other than those mentioned could have been produced from the places of articulation but they had no need of more than the ones they proclaimed. It seems that it will be impossible for us to know the truth with regard to this issue.

\section{II.L.1.4.2.}

[ ] not true. Since it is of this nature, knowledge [ ] than ignorance. Since the knowledge of the technique of reading is explicated through (its analysis into) letters, vowels, accents and

\footnotetext{
${ }^{6}$ Literally: the masters.
} 
פצל II.L.1.4.

II.L.1.4.1. אן קאל מא אלפאידה פי מערפה מחאל אלחרוף קיל לה לו סאל סאיל פקאל מא אללגה לקלת הי עבאראת תואצע עליהא ארבאבהא ליפהמו אגראצהם לבעצהם בעץ ויחתאג אן יעלם 280 אלתי מנהא יצח אן תנבני אלעבאראת פהי ללעבאראת אצולא פאתצח בעלם אלמחאל חכמה אלמתואצעין באן עלמו אן אלגרץ יכמל באתני ועשרין חרפא ובדון דלך לא יכמל ואתכדוהא מן כמסה מחאל אצול ומחל ואחד פרע עלי מא מצא ביאנה פאמא אן יכון לא יצח מן כל מחל גיר מא דכר מן אלחרוף או עלמו אן יצח מן אלמחאל גיר אלחרוף אלמדכ[ורה] גיר אן לם תדעהם אלחאגה אלי אכתר ממא דכרוה וקריב אנא תתעדר מערפה צחה דלך

[1:11v) 290 
the shewa, it is appropriate for the necessary description to be made of each of these, in order for me to demonstrate the superiority of this language over other languages, since it is 'a pure language' (Zeph. 3.9). Given that among the letters of Hebrew there are several letters, as explained above, that are

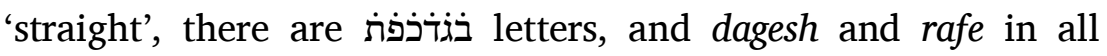
remaining letters except אהזהע, if one were to say 'What is the function of dagesh and rafe?', the response would be as follows. There is clearly a function. This includes the change of meaning

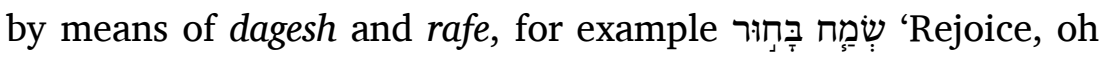
young man!' (Ecc. 11.9), which is an intransitive verb, since the mem in it is light. If it has dagesh, the verb becomes transitive, as

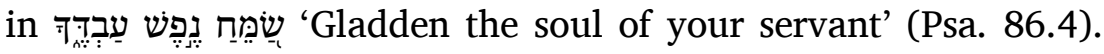

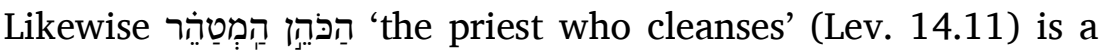

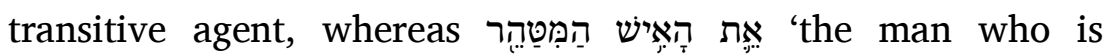
cleansed' (Lev. 14.11) is a reflexive agent, and similar cases.

\section{II.L.1.4.3.}

The people of the language used words from one place of articulation, such as אָָהָה 'Oh!', which is from the place of

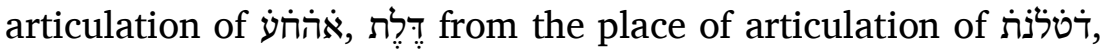

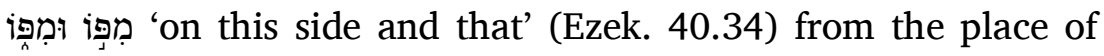
articulation of בוֹמì, and similar cases.

GAP

\section{II.L.1.4.4.}

[...] The third category is what interchanges in one place of articulation, for example

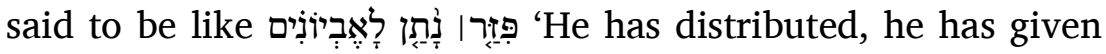
to the poor' (Psa. 112.9). The place of articulation of bet and pe

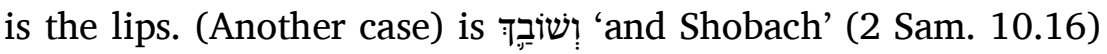

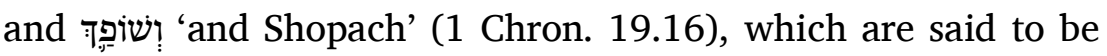


ואלחאן [י]שוא חסן אן ידכר פי כל ואחד מא יסנח ויתגה פיה לאביין שרף הדה אללגה עלי סאיר אללגאת לאנהא שפה ברורה ואדא פי חרוף אלעבראני כאנת חרוף עדה עלי מא דכר פי מא תקדם מן אלפשוטות ובגֹדذפת ואלדגש ואלרפי אלדי פי בקיה אלחרוף סוא אההחע פאן קיל פמא אלפאידה פי אלדגש ואלרפי קיל לה לא בד מן פאידה מן דלך תגייר אל[מע]נא באלדגש ואלרפי מתל שְׁמַח בָחוּר אלדי הו פעל פי אלנפס לכון אלמים גאת פיה כפיפה ואדא גאת מדגושה תעדי אלפעל כק שַׁמַחח נפש עבדך וכדלך הכהן הַמְטַהַר פאעל באלגיר את האיש הַמִַַּהַר פאעל בנפסה ואמתאל דלך

II.L.1.4.3. ואסתעמל אהל אללגה אלכלאם מן אלמחל אלואחד מתל אַהָה

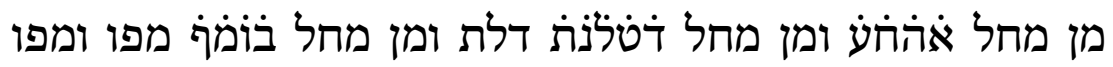

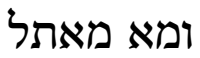

\section{GAP}

II.L.1.4.4. (L3:14r) בזר אלדי יקאל אנה מתל פזר נתן לאביונים אלבא ואלפא מחלהמא אלשפתאן ושובך ושופך אלדי יקאל אנהמא אסם 


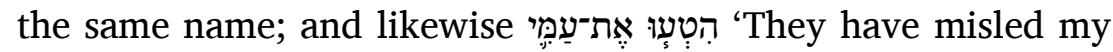
people' (Ezek. 13.10)— הִתְעוֹ (God) caused (me) to wander' (Gen. 20.13), עִּוּשוּ 'Hasten!' (Joel 4.11)—שוּשוּ.

\section{II.L.1.4.5.}

The fourth category is what interchanges from different places of articulation, which includes scribal error and ciphers, for dalet and resh (which are sometimes confused by scribal error) are from two different places of articulation and the cipher (consisting of the interchange of) bet and shin is from two different places of articulation. Interchanges that are from a single place of articulation do not fall into this category, as will be explained in a separate chapter (see §II.L.1.5.).

\section{II.L.1.4.6.}

Take note that it is said that some letters are contracted. Their contraction is indicated by two things: meaning and grammar. Some letters are augments at the beginning, middle or end of a word.

\section{II.L.1.4.7.}

An example of an augmented letter at the beginning of a word is

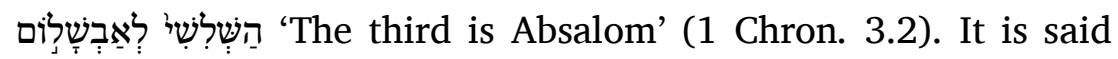
that the presence of this lamed has no meaning and the meaning would remain the same if it were elided. An example of an

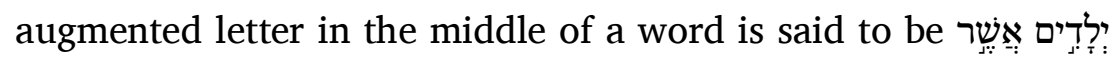

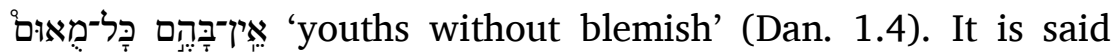
that the 'alef in מִאזום is augmented, without any function, because the lexical class of 'blemish' does not contain a root letter 'alef. Examples of an augmented letter at the end of a

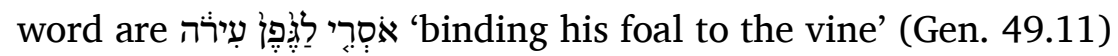


ואחד וכדלך הטעו את עמי התעו עושו חושו

II.L.1.4.5.

ואלקסם אלראבע מא ינבדל מן מחאל מתגאירה והו יעם אלתצחיף ואלגמטריא לאן אלדאל ואלריש מן מחלין גירין ואלגמטריא אלבא ואלשין מן מחלין >מתגאירין> פמא כאן מן מחל ואחד אנבדאלה לא ידכל פי הדא אלקסם עלי מא סיגי ביאנה פי באב מפרד

II.L.1.4.6. ואעלם אן קד קיל אן פי אלחרוף איצא מא יכתצר וידל עלי

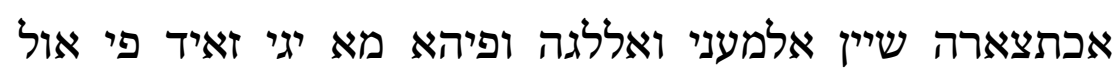
אללפט ואלוסט ואלאכר

II.L.1.4.7. פאלזאיד פי אול אללפט השלישי לאבשלום קיל אן הדא אללמאד לא מעני לתבותה בל ינ[תט]ם אלמעני בחדפה ואלזאיד פי וסט אלכלאם קיל מתל ילדים אשר אין בהם כל מאום פקיל אן אלאלף פי מאום זאיד לא פאידה פיה לאן לגה אלעיב מא פיה אלף אצלי ואלזאיד פי אכר אללפט כקולה (L3:14v) 


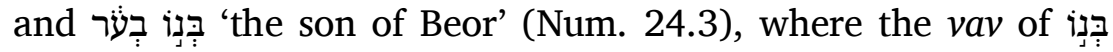
has no meaning, and likewise the yod in since it is not a pronoun, and similar cases.

\section{II.L.1.4.8.}

As for cases of the contraction of a letter that is reflected by the meaning, it is said to include examples such as הַיוֹס בְּיָּד 'for the Lord gave you into my hand today' (1 Sam. 26.23), where it is said that a yod has been contracted in $T_{\tau}^{\text {, and }}$

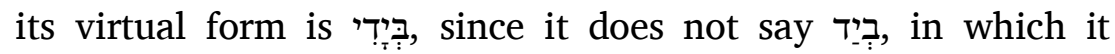
would be conjoined to an underlying noun, but rather it is pronounced in its disjoined form, which is with qames. Likewise

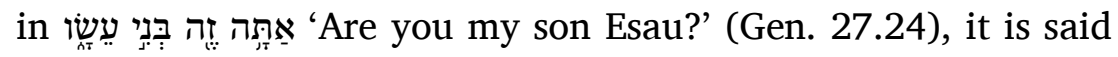
that a he has been contracted in אָתָ since it does not have the function of a declarative but rather of an interrogative, and its

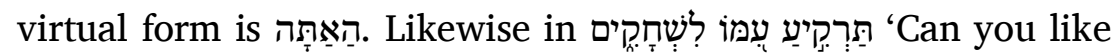
him spread out the skies?' (Job 37.18) an interrogative he is contracted in it and its virtual form is

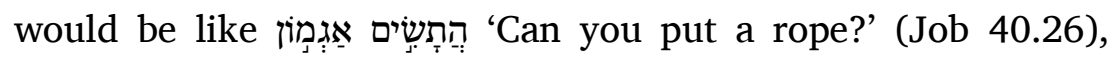

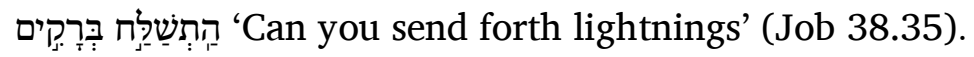

\section{II.L.1.4.9.}

As for cases of the contraction of a letter that is reflected by the

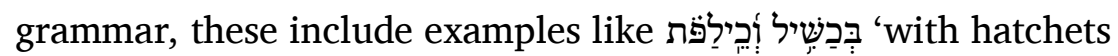
and hammers' (Psa. 74.6), since it should according to rule have

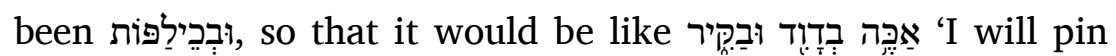

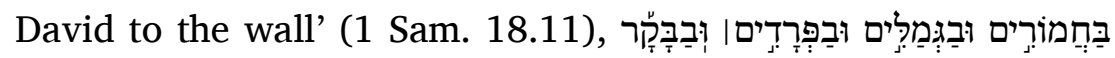
'on asses and on camels and on mules and on oxen' (1 Chron. 12.41), for this is the rule for the co-ordination of two nouns after one another with the particle bet. 
אסרי לגפן עירה בנו בעור אלדי אלואו פי בנו לא מעני לה וכדלך אליוד פי אסרי לאנה ליס צמיר ומא מאתל דלך

II.L.1.4.8. ואמא מא יכתצר ויתבתה אלמעני פקיל אנה מתל אשר נתנך ייי היום ביד אלדי יקאל אנה מכתצר יוד פי יד ותקדירה בידי לאנה מא קאל ביבד פיכון מצאף אלי אסם מצמר בל אכרגה בכרוג אלקטע והו אלקָמֵץ וכדלך אתה זה בני עשו קיל אן אלהא מן אתה מכתצר לאן ליסה מוצע כבר בל אסתפהאם ותקדירה האתה זה ומתלה תרקיע עמו לשחקים הא אלתמה מכתצר מנה ותקדירה התרקיע עמו ליגרי מגרי התשים אג' התשלח ברקים

II.L.1.4.9. ואמא מא יכתצר פתתבתה אללגה הו כקוֹ בכשיל וכלפות אד כאן חקה אן יגי ובכלפות ליגרי מגרי אכה בדוד ובקיר בחמורים ובגמלים ובפרדים ובבקר אד דלך מן חק אלעטף פי אלאסמין אלמעטוף אחדהמא עלי אלאכר בחרף בא 


\section{II.L.1.4.10.}

When two identical letters succeed one another at the end of one word and the beginning of another and the two words are linked by an accent, if the reader is not careful to pronounce them both, one of them would become coalesced and they would be pronounced as one letter. The reader must pronounce them clearly in order to distinguish, for example, the two sades

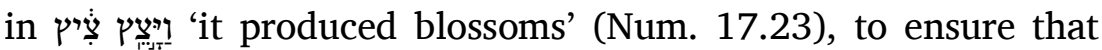
the two nuns are pronounced in 'then Nebuchadnezzar' (Dan. 3.13, etc.) and to ensure that the two mems are

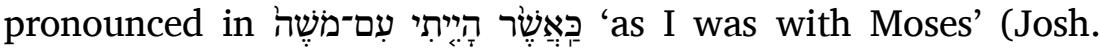
1.5, etc.), and similar cases of two letters succeeding each other in this manner.

\section{II.L.1.5. Chapter on the Interchange of Letters}

\section{II.L.1.5.1.}

It is said that among the letters are those that interchange from the same place of articulation, so that, for example, 'alef

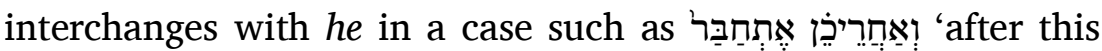
he joined' (2 Chron. 20.35). This is in place of because the 'alef in אתתחברבר is not the 'alef of the first person future, but is

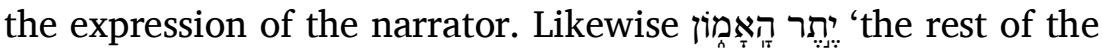

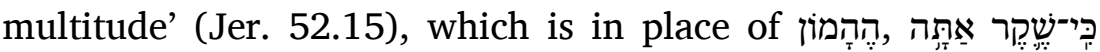

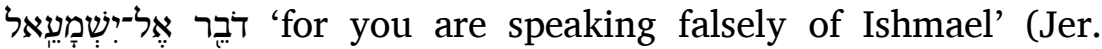

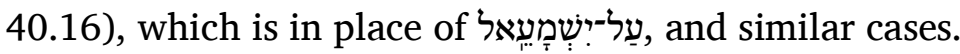

\section{II.L.1.5.2.}

From the place of articulation of ב̇i், bet interchanges with pe,

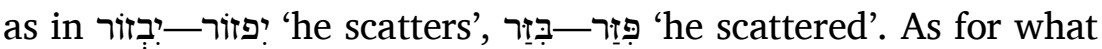
interchanges from two different places of articulation, this is like

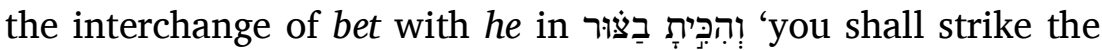
rock' (Exod. 17.6), which is said to be in place of הצוּר 
II.L.1.4.10.

ואלחרוף אדא תראדף מנהא חרפאן פי אכר אלכלמה ואחד ופי אול אלאכרי אכר מתלה וכאנתא אלכלמתאן מכתלטתין באללחן אן לם (L3:15r) יגעל אלקאר באלה אליהמא ליטהרהמא ואלא אנדגם אלואחד וכרגא מכרג חרף ואחד פיגב אן יטהרהמא אלקאר ליבין אלצאדין פי וּיצֵץ ציץ ויכון אלנונין פי באדין נבוכדנצאר ויכרג אלמאמין פי כאשר הייתי עם משה ומא מאתל דלך מן אלחרפין אלמתראדפה עלי הדא אלוגה

\section{II.L.1.5.}

II.L.1.5.1. קיל אן פי אלחרוף מא ינבדל מן מחל ואחד פינבדל אלאלף באלהא כקוֹ ואחריכן אתחבר פהו מקאם התחבר לאן ליס אלאלף פי אתחבר אלף אלאסתקבאל אלדי ללמתכלם בל הו קול אלמכבר וכדלך יתר האמון מקאם ההמון כי שקר אתה דובר אל ישמעאל הו מקאם על ישמעאל ומא מאתל דלך II.L.1.5.2. ומן מחל בَוֹמֹף ינבדל אלבא באלפא כקוֹ יבזור יפזוֹר בִּזָר פִזָר ואמא מא ינבדל מן מחאל מתגאירה מתל מא ינבדל אלבא באלהא בק והכית בצור קיל אנה מקאם הצור 


\section{II.L.1.5.3.}

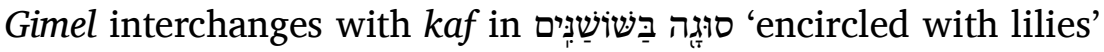

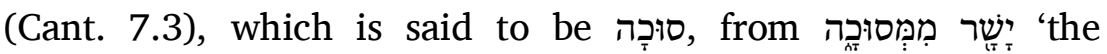
upright from a thorn hedge' (Micah 7.4), since it does not make sense for it to be derived from toָסגו אָחוֹר 'they shall be turned back' (Isa. 42.17, etc.). These two letters are from the same

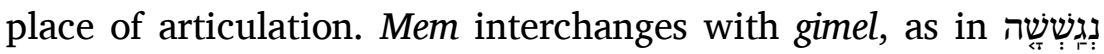
כָעִוְרים 'We grope like the blind' (Isa. 59.10), which is in place of

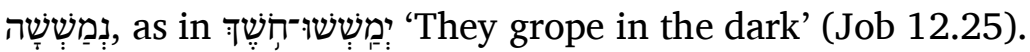

\section{II.L.1.5.4.}

Dalet interchanges with zayin, as in דִָּה - The interchange of) resh with dalet is due to scribal error, as in 'Reuel'-

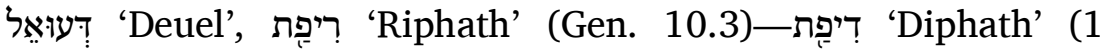

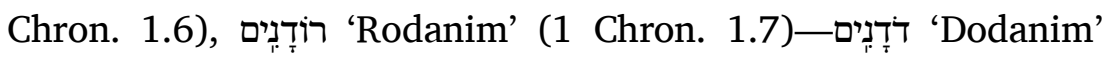
(Gen. 10.4).

\section{II.L.1.5.5.}

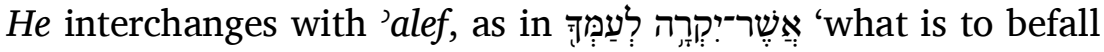
your people' (Dan. 10.14), in which (the 'alef of the qere) is in

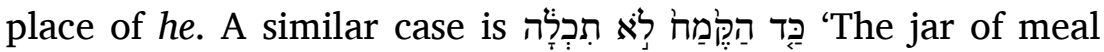
shall not be spent' (1 Kings 17.14). This is from the same place of articulation. A case of interchange from two places of

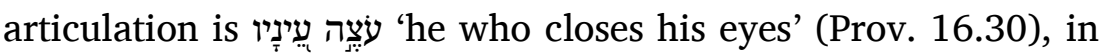

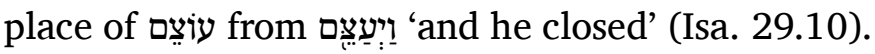

\section{II.L.1.5.6.}

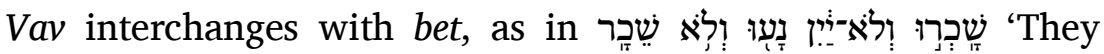
were drunk, but not with wine; they staggered, but not with

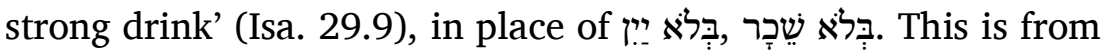
the same place of articulation. From two places of articulation it

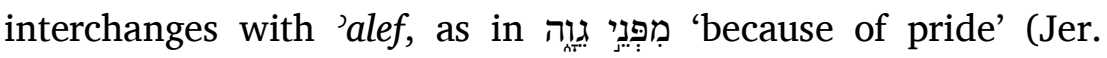
13.17), which is said to be in place of גָאָה. 
II.L.1.5.3.

אלגמאל ינבדל בכאף סוגה בשושנים קיל אנה סוכה מן ישר

ממסוכה אד כאן לא מעני להא מן נסוגו אחור והדין אלחרפין מן מחל ואחד ואלמאם (L3:15v) ינבדל בגמאל כز נגששה כעורים

מקאם נמששה כקו ימששו חשך

אלדאל ינבדל בזאי כקו זהב דהב ואלריש באלדאל מן אלתצחיף רעואל דעואל ריפת דיפת רוֹדָנים דודְנים

II.L.1.5.5.

אלהא ינבדל באלף כקוֹ אשר יקרא לעמך מקאם הא וכדלך כד הקמח לא תכלה והדא מן מחל ואחד ומן מחלין עוצה עיניו

מקאם עוצם מן ויעצם

אלואו ינבדל בבא כק שכרו ולא יין נעו ולא שכר מקאם בלא יין 360 בלא שכר והדא מן מחל ואחד ומן מחלין ינבדל באלף כק מפני גָוְה קיל אנה מקאם גָאָה 


\section{II.L.1.5.7 .}

Zayin interchanges in the same place of articulation with șade,

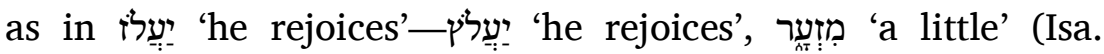
10.25, etc.)— מִצְעָר 'a little one' (Gen. 19.20, etc.). An example from two places of articulation is קִּפר 'hedgehog' (Isa. 14.23, etc.)—ị ? 'hedgehog' (Isa. 23.15).

\section{II.L.1.5.8.}

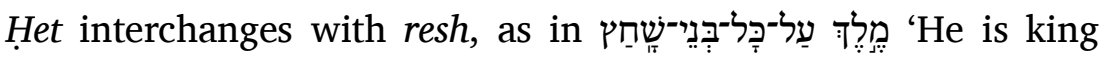
over all creeping creatures' (Job 41.26), which is in place of שֶׁרִ. These are from two places of articulation.

\section{II.L.1.5.9.}

Tet interchanges in the same place of articulation with tav, as in

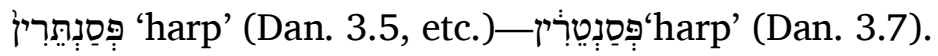

\section{II.L.1.5.10.}

It is said that yod interchanges with 'alef, as in 'and I shall cast you down from your station' (Isa. 22.19), in

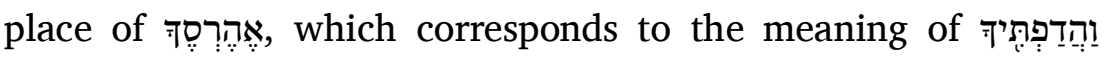
'and I shall cast you down' (Isa. 22.19).

\section{II.L.1.5.11.}

It is said that kaf interchangs with bet, as in 2

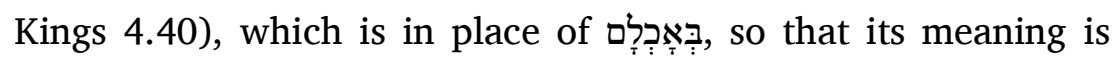
'while they were eating (pottage)', since a comparison here is

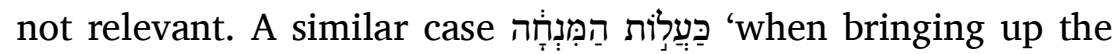

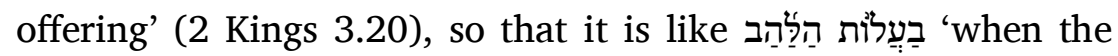
flame went up' (Jud. 13.20). This is from two places of articulation. A case from the same place of articulation is

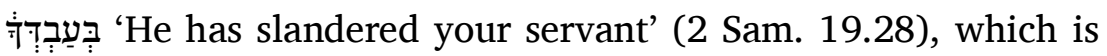

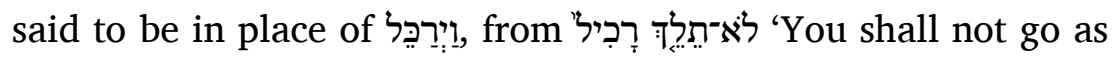
a slanderer' (Lev. 19.16). 
II.L.1.5.7. אלזאי ינבדל מן מחל ואחד בצדי יעלז יעלץ מזער מצער ומן מחלין קפוד קפוז אלחית ינבדל בריש כל מלך על כל בני שחץ אנה מקאם שרץ 365

II.L.1.5.9. אלטית ינבדל מן מחל ואחד בתזו פסנתרין פסנטרין אליוד קיל אנה ינבדל באלף כ.L.1.5.10. ויואפק מעני והדפתיך

אלכאף קיל אנה ינבדל בבא ذק כאכלם מהנזיד הו מקאם באכלם ליכון מענאה ענד אכלהם (L3:16r) לאן אלתמתיל מא לה הונא מדכל ומתלה כעלות המנחה ליגרי מגרי בעלות הלהב והדא מן מחלין ומן מחל ואחד וירגל בעבדך קיל אנה מקאם וירכֵל מן לא תלך רכיל 


\section{II.L.1.5.12.}

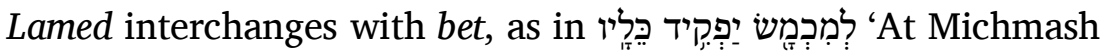

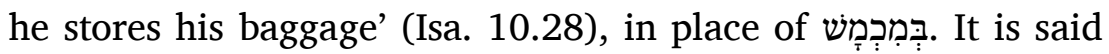

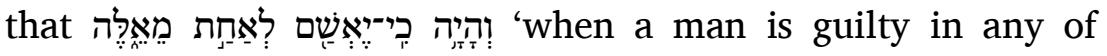

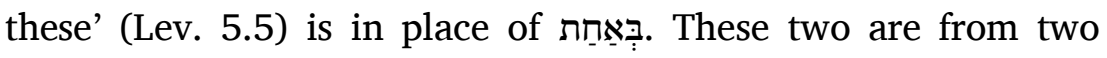
places of articulation. An example from one place of articulation

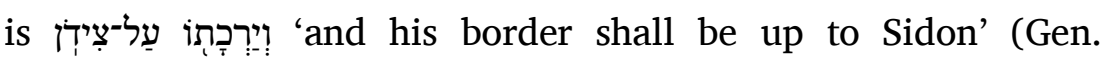
49.13), which is said to be in place of עַד־צִידוֹן עִ עִ

\section{II.L.1.5.13.}

It is said that mem interchanges with bet, in the same place of

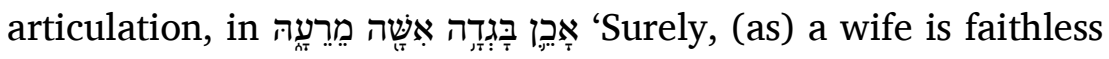

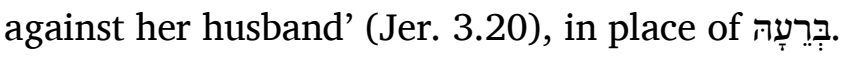

\section{II.L.1.5.14.}

Nun interchanges with mem from two places of articulation, for

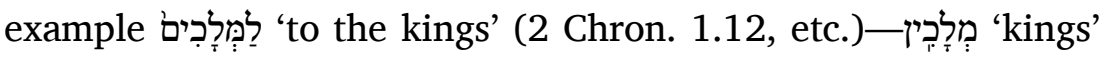

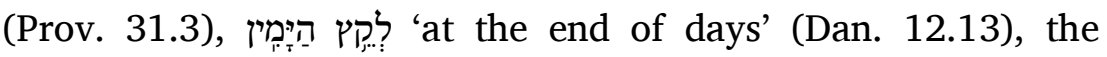
virtual form of which is הַיָיָמים

\section{II.L.1.5.15.}

Samekh interchanges with sade in the same place of articulation,

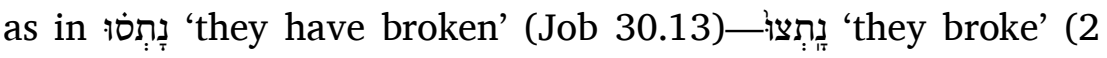
Kings 25.10, etc.). It is also said that יקוֹסֵס 'he will cut' (Ezek. 17.9) is in place of יקוֹציץ:.

\section{II.L.1.5.16.}

It is said that 'ayin interchanges with hִet, as in עַוּשוּ 'hasten' (Joel 4.11)—חוּשו. 
II.L.1.5.12.

אללמאד ינבדל בבא מתל למכמש יפקיד כליו מק במכמש 375 וקאלו אן והיה כי יאשם לאחת מאלה אנה מקאם באחת והדין מן מחלין ומן מחל ואחד וירכתו על צידון קאלו אנה מקאם עד צידון

II.L.1.5.13. ואלמים קיל אנה ינבדל בבא והו מן מחל ואחד אכן בגדה אשה מרעה מקאם ברעה

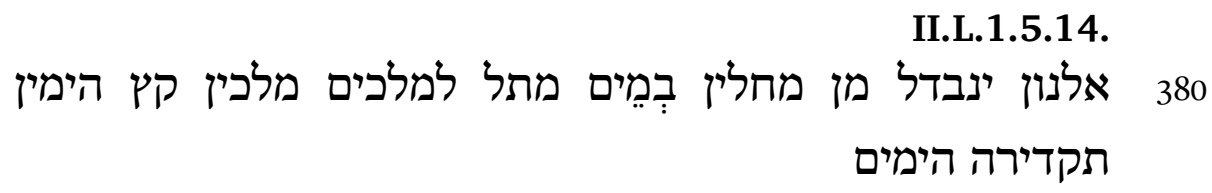

II.L.1.5.15. אלסמאך ינבדל בצדי מן מחל ואחד נתסו נתצו וקיל אן יקוסס

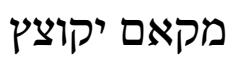

II.L.1.5.16. אלעין קיל אנה ינבדל בחית מתל עושו חושו 


\section{II.L.1.5.17.}

$P e$ interchanges with bet from the same place of articulation in

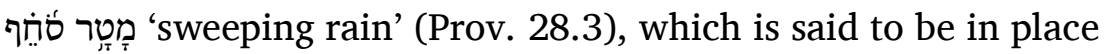

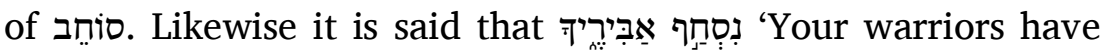
been dragged away' (Jer. 46.15) is in iִnָב

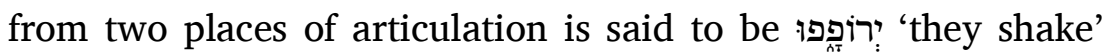

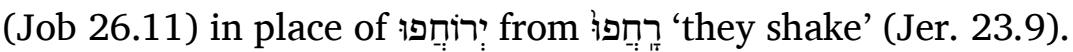

\section{II.L.1.5.18.}

It is said that sade interchanges with samekh in the same place of articulation, as in חִמְוּץ בְּגָרדים 'blood red of garments' (Isa. 63.1).

\section{II.L.1.5.19.}

It is said that qof interchanges with kaf in the same place of כָוֹבַע 'helmet' (1 Sam. 17.5, etc.).

\section{II.L.1.5.20.}

It is said that resh interchanges with kaf, as in

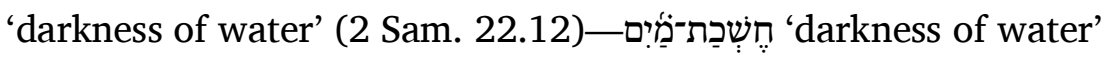
(Psa. 18.12).

\section{II.L.1.5.21.}

Shin interchanges with samekh in the same place of articulation

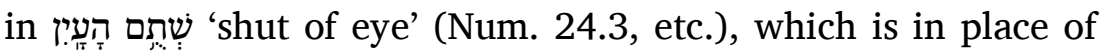

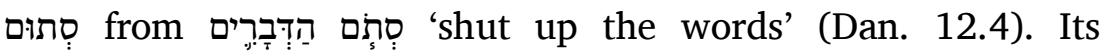
interpretation as 'placed' is not plausible. This is because שִ שֶתתם is a conjoined passive participle. The disjoined form would be

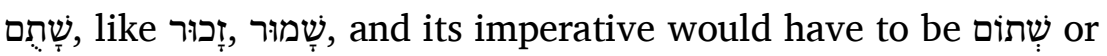
שִׁתֵם This would lead to the conclusion that there is a root letter mem in the lexical class of 'placing', but this is not the case,

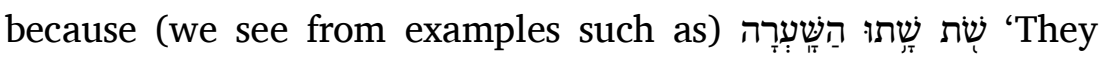


II.L.1.5.17.

385 אלפא ינבדל מן מחל ואחד בבא מטר סוחף קיל אנה מקאם סוחב וכדלך נסחף אביריך קיל אנה מקאם נסחב ומן מחלין קיל ירופפו מקאם ירוחפו מן רחפו

II.L.1.5.18.

אלצדי קיל אנה ינבדל בסמאך מן מחל ואחד מתל חמוץ בגדים

אלקוף קיל אנה ינבדל מI.L.1.5.19. כובע

II.L.1.5.20. אלריש קיל אנה ינבדל בכַּף מתל חשרת מים חשכת

II.L.1.5.21 אלשין ינבדל מן מחל ואחד בסמאך והו שתום העין מק סתום מן סתום הדברים ואלדי פסרה מגעול מא הו תפסיר קריב ודלך אן שתום מפעול מצאף ואלמכרת יכון שָתום מתל זָכור שָמור ויגב אן יכון אמרה שְתוֹם או שְתַם והדא יודי אלי אן יכון פי לגה אלאגעאל מים אצלי וליס אלאמר כדלך לאן קוֹ שֶת שָתו 


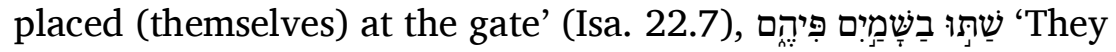

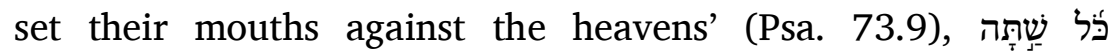

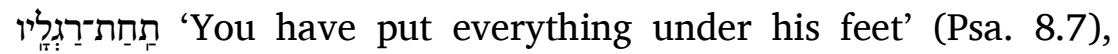
(that) all forms from the lexical class of 'placing' lack mem.

\section{II.L.1.5.22.}

It is said that tav interchanges with 'alef, as in took a cedar tree and an oak' (Isa. 44.14), which is in place of אַר 'cedar' (Zeph. 2.14). This is a short sample of the interchange of letters.

\section{II.L.1.6. Chapter concerning the Influence of the Four Letters 'alef, vav, yod and he, I mean אiאיה, on the Six

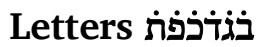

When one of these four is at the end of a word and the word is conjoined with what follows it by the accent, and the second word begins with one of the letters ذ̇خذذפת, this letter is

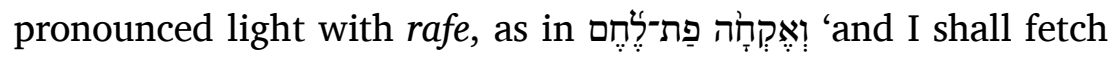

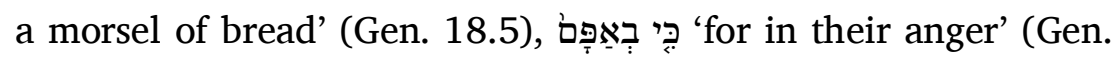

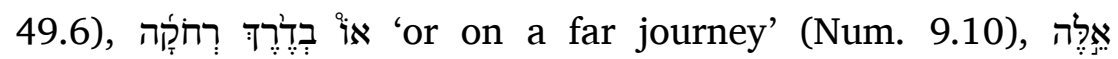

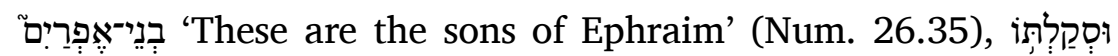

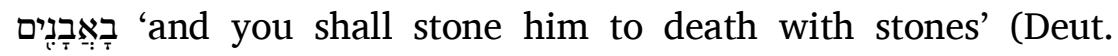

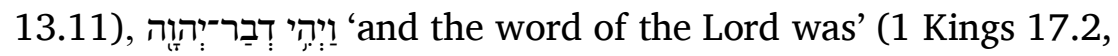
etc.), and very many similar examples of what is not disjoined from the (preceding) accent. In every case where there is no disjunction from the (preceding) accent in this way, the letters are light, with rafe.

\section{II.L.1.7. Section (on Deviations from the General Rule)}

\section{II.L.1.7.1.}

The cases that deviate from what I have stated are nine exceptions to the rule concerning which there is, to my knowledge, no disagreement. I shall exclude from the discussion 
השערה שתו בשמים פ כל שתה תחת רג כל לגה אלאגעאל מא

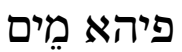

II.L.1.5.22. אלתָו קיל אנה ינבדל באלף בק ויקח תרזה ואלון מקאם ארזה פהדא טרף מן אבתדאל אלחרוף באכתצאר

באב פי מא תותרה אלארבעה חרוף והי אלאלף (L1:14r) II.L.1.6.

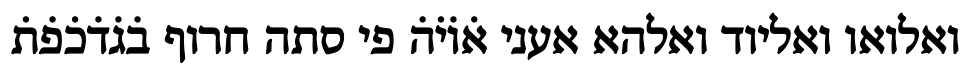
הדה אלד אדא כאן אחדהא פי אכר כלמה וכאנת אלכלמה מצאפה אלי מא בעדהא באללחן וכאנת אלכלמה אלתאניה אולהא אחד חרוף בגדֹذפּ כרג דלך אלחרף מרפיא כפיפא כק

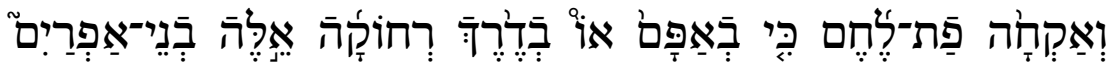

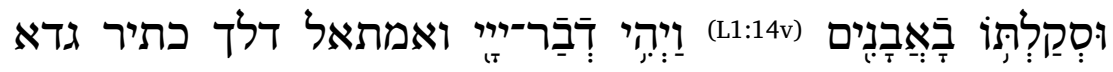
ממא לא ינפצל מן אללחן פכל מא לא ינפצל מן אללחן עלי הדא אלמנהאג תכון חרוף ذגֹדذפּ מרפיה כפיפה

פצל II.L.1.7.

II.L.1.7.1. אלדי כרג ען מא דכרת תסעה כואסר ממ[א ל]ם יכתלף פיהא עלי עלמי ואנא אפרד מא אכתלף פיה פי אלדכר דאך אן מא 
cases concerning which there is disagreement. This is because when there is no disagreement about a case, the reader cannot change anything, but when disagreement has occurred concerning a case, the reader makes a choice. He reads whatever variant he wishes. Nobody who may wish to reject it is able to reject it, since he would be rejecting something concerning which there is disagreement, involving one (reading) and an alternative. He (the reader) may read the one reading or the two alternatives (i.e. with dagesh or rafe) interchangeably. So long as this is the situation, a rule cannot be fixed. A rule can only be fixed for something concerning which there are no disagreements. Cases concerning which there is no disagreement include, as far as I can see, the following nine exceptions to the rule: 'oghera, di-fsiq, di-dhhiq, 'athe me-rahiq, mappiq he, mappiq vav, mappiq yod, two identical letters, bet and pe.

\section{II.L.1.7.2.}

As for 'oghera, this is the 'collection' of only seven words. People, however, often add to them what does not belong to them, and introduce variant readings with regard to them. What is contained in this exception to the rule are four words in the

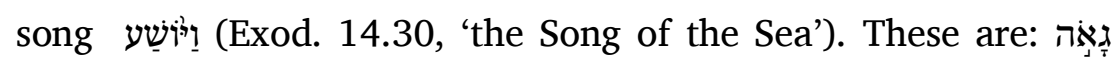
ำ ำ 'He has triumphed gloriously' (Exod. 15.1, 21), which Moses

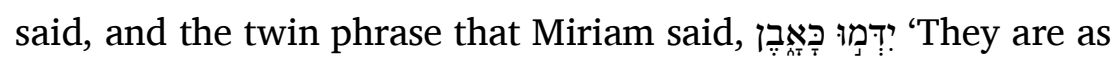
still as a stone' (Exod. 15.16), מִי כָּמָמָָ 'Who is like you?' (Exod. 15.11). In this song there is one word that one may think is analogous to these four, but it is not the case, rather there is

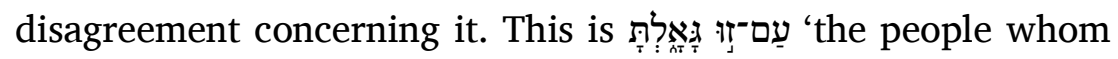
you have redeemed' (Exod. 15.13). There are only these four in the song that belong to the exceptional group 'oghera. In the 
לם יכתלף פיה לא יקדר אלקאר יגייר מנה שיא ואלדי חצל פיה אלכלף אלקאר מכייר אי אלאכתלאף אראד קרי ולא יתסע למן ירד עליה אן ירד לאן ירד אלכלף אלואחד וכלאפה לה אן

יקראה או יקרא אלכלאפין עלי סביל אלבדל פמא כאן הדא חאלה לא ינצבט בה אצלא ואנמא ינצבט מן אלאצול מא לם יקע פיה כלף פאלדי מא וקע פיה כלאף עלי טני הי הדה

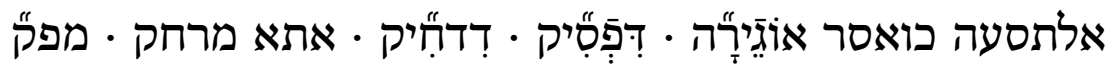
הא • מפק ואו • מפק" יוד • חרפין מתראדפין • בא ופא

II.L.1.7.2. פאמא אלאוגירה פהי אלגאמעה לסבעה כלם פקט ואלנאס כתיר >מא> יציפו עליהא מא ליס מנהא וידכלו פיהא אלכלף ואלדי פי הדה אלכאסרה ארבע לפטאת פי שירת ויושע והי (L1:15r)

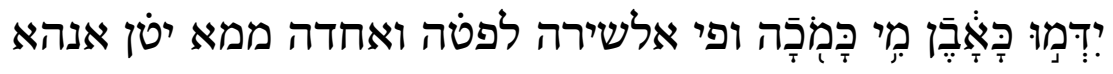

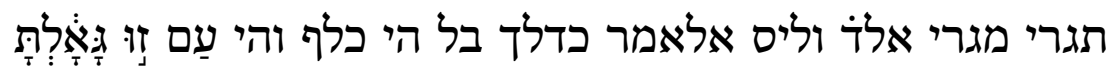
וליס פי אלשירה מן כאסרה אוֹגִירָה סוא הדה אלד ואלארבע 
first four books there is nothing, except that there is what may be imagined belongs to the exceptional group, but it is not the

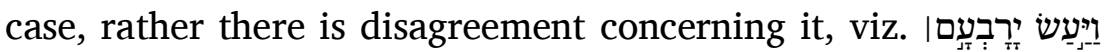

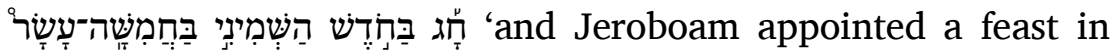
the eighth month on the fifteenth (day)' (1 Kings 12.32). There

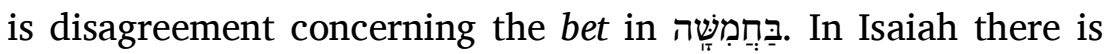

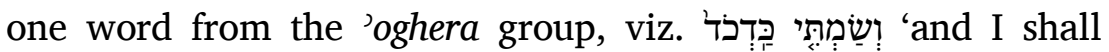
make (your pinnacles) of agate' (Isa. 54.12), in Jeremiah, viz.

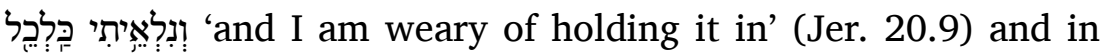

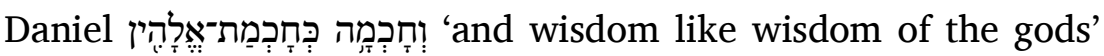
(Dan. 5.11). These seven aforementioned cases are called

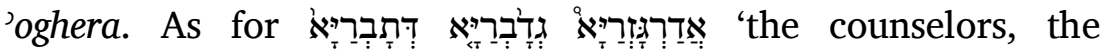

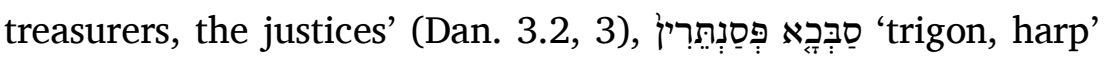
(Dan. 3.5), they are cases of disagreement. I do not know for what reason this group of (seven) exceptional cases breaks the rule of the letters אi listening to the transmitters of the reading.

\section{II.L.1.7.3.}

The second type of case that breaks the rule is di-fsiq (i.e. 'what is paused'). Whenever paseq comes between one of the letters אוiיה because they only have influence when there is nothing cutting (them off from what follows). The paseq cuts (them off) in a way and so this is the reason why the rule of אi אis is not observed, as

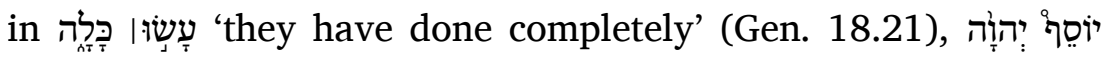

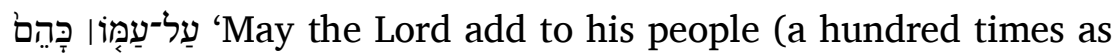
many) as them' (1 Chron. 21.3). There is no exception at all to this type of case that breaks the rule. Whenever a paseq occurs, the rule of אוֹיنה is broken. 
אספאר אלאולה מא פיהא מנהא שי גיר אן פיהא מא יתוהם אנה מנהא וליס אלאמר כדלך בל הו כלף ויעש ירבעם| חג בחדש השמינֶי בחמשה עשר פאן אלבא פי בחמשה כלף ופי ישעיה מן אוגירה לפטטה ואחדה והי ושַׁמְתֶי כַּדְכוד ופי ירמיה

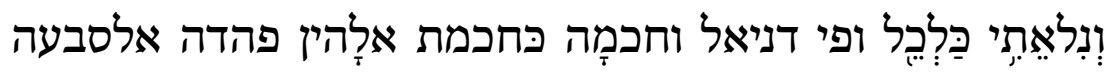
אלדי תקדם דכרהא והי אלמסמאה אוֹגָירָה ואמא מא כאן אדרגזריא גדבריא דתבריא >פסנתרין> פהו כלף ומא עלמת לאי עלה כסרת הדה אלכאסרה עלי שרט אלאוֹיה ואנמא נאכדהא מן אהל אלקראה סמעא

II.L.1.7.3. אלכאסרה אלذ דפסיק כל מא חצל אלפָסֵק בין חרף אלאוּיה ובין אחד חרוף בֹ̇דذפֹ לם יכון ללאויה תאתיר לאן אנמא תותר אדא לם יכון מא יקטע ואלפסק קטע עלי וגה פצארת (L1:15v) הדה אלעלה לא יתבת מעהא שרט אלאוֹילה כק עָשוּוּ| כָּלָה יוסף ייי על עמון כּהַם וליס עלי הדה אלכאסרה אסתתני בתה פכּל מא חצל אלפסק כסר שרט אלאויה 


\section{II.L.1.7.4.}

The third type of case that breaks the rule is di-dhhiq (i.e. 'what is compressed'). Know that this breaking of the rule consists of what is compressed with regard to the rule regarding them (i.e. the letters (אi), and that is why they say di-dhhiq. The meaning of di-dhhiq is that between the accent that is in the word containing one of the בגדiذפת letters and leter is a vowel and this vowel is not dwelt upon or prolonged in pronunciation. On account of this compression (of the vowel)

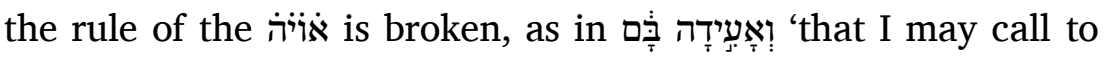

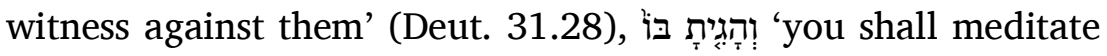
on it' (Josh. 1.8) and similar cases. The compression may occur in a word that does not have an accent but is a small word, as in

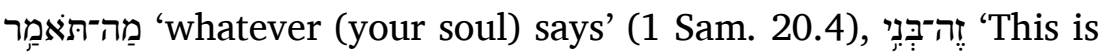
my son' (1 Kings 3.23), מַה־בּּרִ 'What, my son?' (Prov. 31.2),

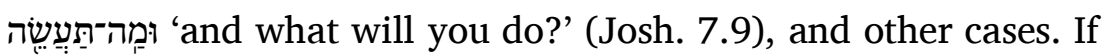

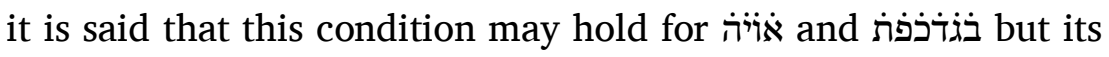

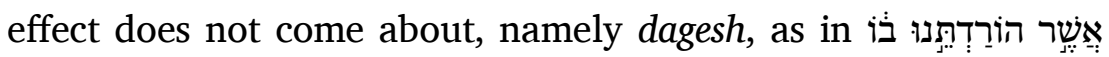

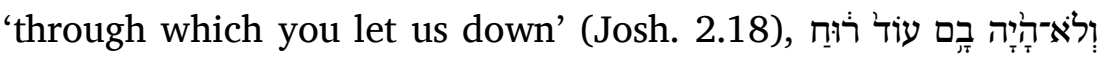

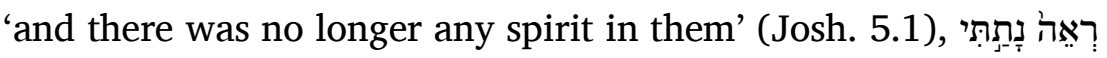
בִיָדָר 'See, I have given into your hand' (Josh. 6.2), and the

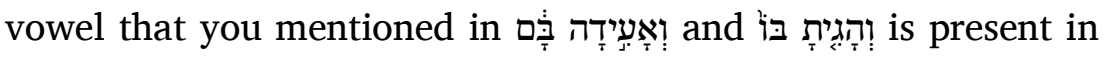

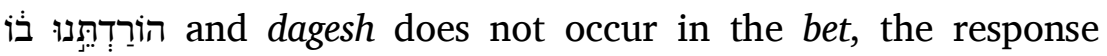
should be that the difference between what you mentioned (and the cases with compression) is that the vowel that is after the accent in does not have an exhalation of breath but is

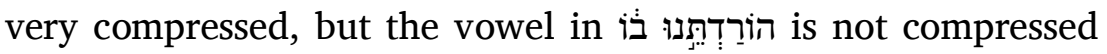
in the joining (of the words) but is expansive with an exhalation breath, and is like other (long) vowels, or nearly so. Whoever examines this closely will perceive the difference. 
II.L.1.7.4.

אלכאסרה אלג דדחיק אעלם אן הדה אלכאסרה אלציק אלשרט פיהא והו קולהם דדחיק ומעני דדחיק הו אן יכון בין אלטעם אלדי פי אלכלמה אלדי פיהא חרף אלאויنה ובין חרף ذגד ذפּ מלך ואחד ולא יתאנא ולא יטול פי אלנטק בדלך אלמלך פלאגל הדא אלציק כסר שרט אלאויה כקולה וְָָעִיָָהָ

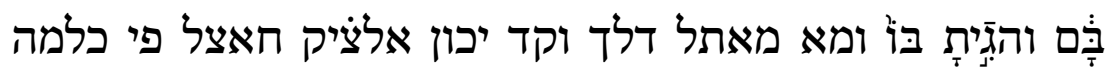
לא יכון פיהא טעם גיר אנה תכון כלמה צגירה כק מֶה־תאמֶמר 450 אלעלה קד תחצל פי אוּיוֹ ובגדֹذפת ולא יחצל מעלולהא והו

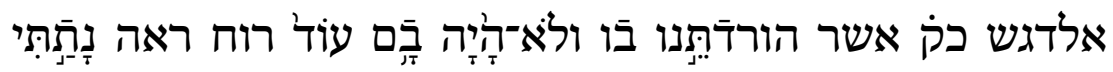

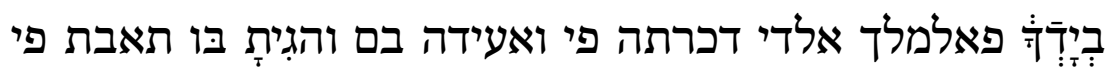
הורדתֵנו בו ולם יחצל אלדגש פי אלבא קיל לה אלפרק בין מא דכרתה הו אן אלמלך אלדי בעד אלטעם (L1:16r) פי ואעידה בם ליס פיה תנפס בל הו מציק גדא וליס כדלך אלמלך אלדי פי הורדתנו בו מציק פי אלנסק בל הו מוסע בתנפס יגרי מגרי מלך אכר או קריב מנה ומן תאמל דלך וגד אלפרק 


\section{II.L.1.7.5.}

The fourth type of case that breaks the rule is 'athe me-rahiq. This is the opposite of the previous type of case that breaks the rule, because the latter (i.e. 'athe me-rahiq) is on account of what is far and the former (i.e. di-dhhiq) is on account of what is near, and so there is a fundamental difference between them. This (i.e. 'athe me-rahiq) arises from the fact that due to the distance of the accent (from the preceding conjunctive accent), one comes upon it (the accent) like a ballista and so the בخגדذפ letter

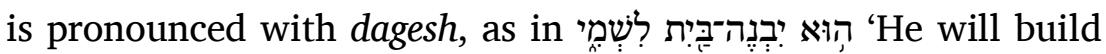

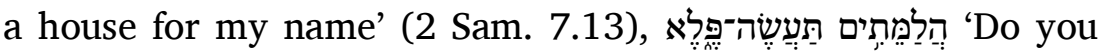

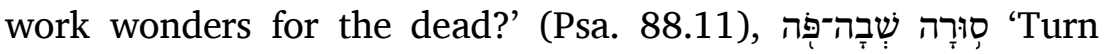
aside, sit here' (Ruth 4.1). Also (included in this category) are cases in which there is no (conjunctive) accent, so (such cases must be considered) to have a virtual (conjunctive) accent

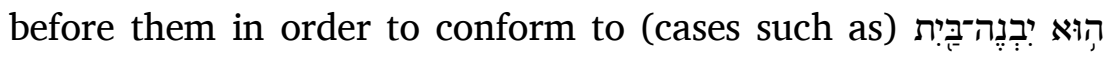

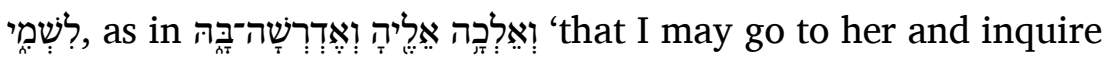
of her' (1 Sam. 28.7), and similar cases.

\section{II.L.1.7.6.}

The fifth type of case that breaks the rule is mappiq he. The meaning of their term mappiq he is the (consonantal) pronunci-

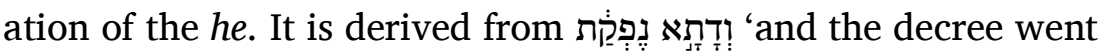
forth' (Dan. 2.13). This is because when the he is pronounced at the end of a word, the rule of the letters is broken, as in

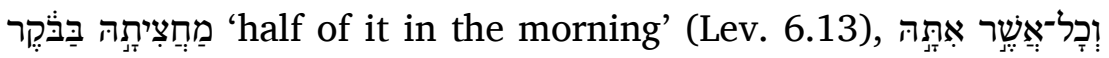
בַבּבּית 'and all those who are with her in the house' (Josh. 6.17),

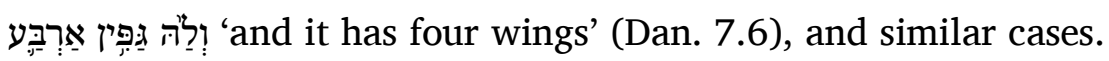
There are no exceptions to this breaking of the rule at all.

\section{II.L.1.7.7.}

The sixth type of case that breaks the rule is mappiq vav. This is because every vav at the end of a word is pronounced according 
II.L.1.7.5.

אלכאסרה אלד אתא מרחיק הדה באלעכּס מן אלכאסרה

460 אלמתקדמה להא לאן הדה למא בעד ותיך למא קרב פשתאן

בינהמא והו אן כמא יבעד אללחן ינצב עליה כּאלמנגניק פידגש

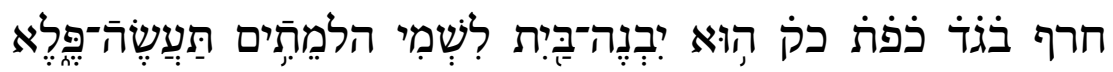

סֵוּרָה שְשבָה־פּּה ומא לם יכון פיה אללחן פהו בתקדיר לחן קבלה

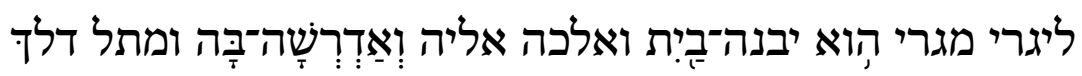

II.L.1.7.6.

אלכאסרה אלכאמסה מפק הא מעני קולהם מפק הא הו כרוג

אלהא ישתק מן ודתא נפקת והו אן אלהא אדא טהר וכרג פי

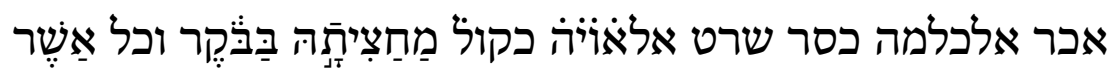

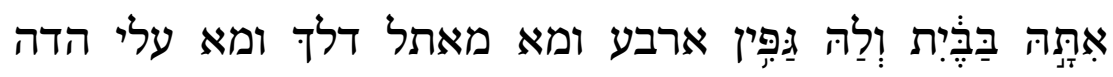
אלכאסרה שיא מסתתנא בתה

II.L.1.7.7. אלכאסרה אלסאדסה מפק ואו ודאך אן כל ואו פי אכר כלמה 
to the Palestinians as a bet rafe, which breaks the rule of the אוֹוּיה (enter) his courts with praise' (Psa.

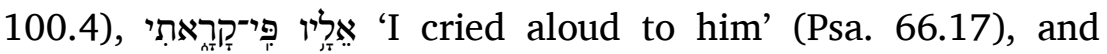
similar cases. There are two words that are exceptions to this

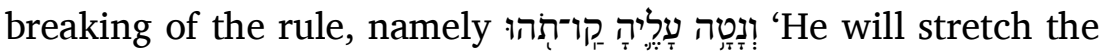

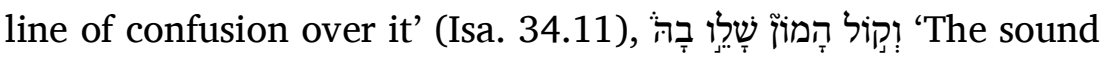
of a carefree multitude was with her' (Ezek. 23.42). Although according to the principle of breaking the rule what follows the two vavs should have had dagesh, this has not occurred.

\section{II.L.1.7.8.}

The seventh type of case that breaks the rule is mappiq yod. Take note that whenever yod occurs at the end of a word and the next word begins with one of the ב̇גדذפו letters, and hireq or șere occurs under the letter before the yod, then the rule of

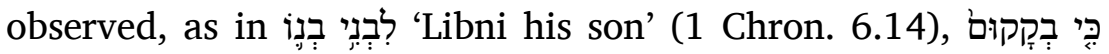

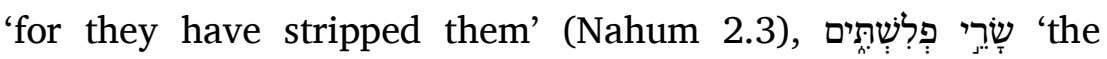
princes of the Philistines' (1 Sam. 18.30), and similar cases. If vowels that are different from the aforementioned occur under the aforementioned letter, the yod is strengthened and the rule

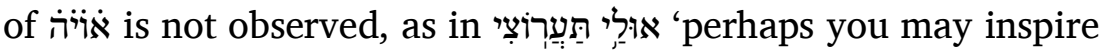

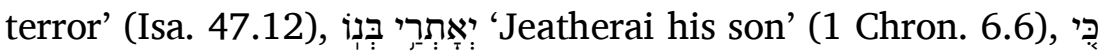

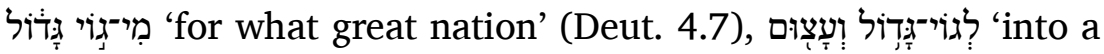

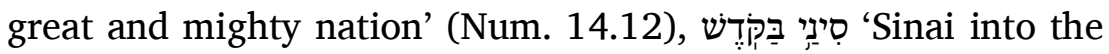
holy place' (Psa. 68.18). One word is an exception to this

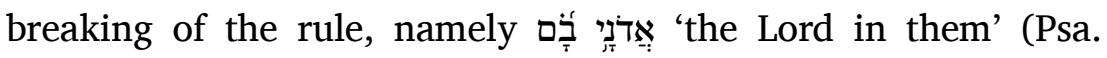
68.18). What should have occurred according to the principle of

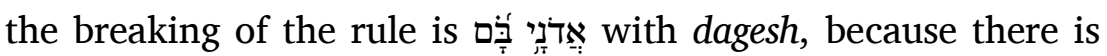
no hireq or sere on the letter before the yod. I do not know for what reason it contravenes the breaking of the rule. 
יכרג עלי ראי אלשאמיין בבא מרפי הו יכסר שרט אלאוּיה כק

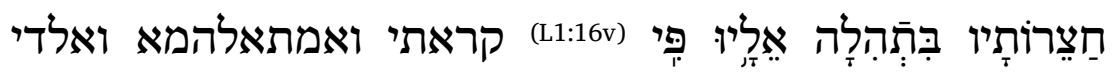
יסתתנא עלי הדה אלכאסרה לפטּתין והמא ונטה עליה קַו תַּהוּ וקול הָמוֹץ שֵֶָׁוּ בָהּ פאן כאן יגב עלי אצל אלכאסרה אן יגי מא בעד אלואוין מדגושא ולם יגי כדלך

II.L.1.7.8. אלכאסרה אלסאבעה מפק יוד אעלם אן כל יוד פי אכר כלמה ואול אלאכרי מן חרוף בּ̇דذפֹ ותחת אלחרף אלדי קבל אליוד

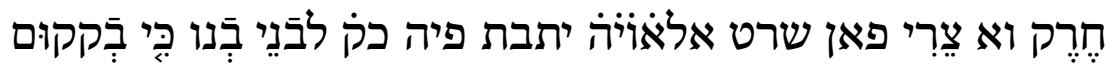

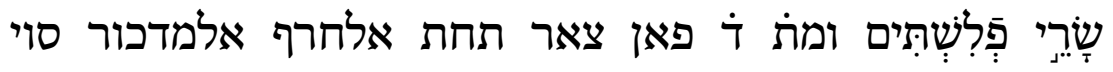
480 אלמלכין אלמדכורין אשתד אליוד ולם יתבת שרט אלאויنה כל

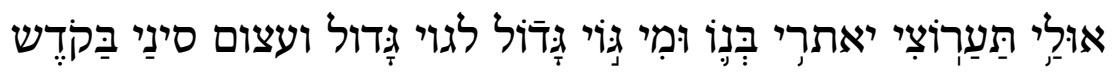
יסתתני עלי הדה אלכאסרה בלפטּה ואחדה והו אדּני ב̇ם וקד יגב אן תגי עלי מקתצא אלכאסרה אדנָי בּם דגש לאן ליס תחת אלחרף אלדי קבל אליוד נקטה ולא נקטתין ומא עלמת לאי עלה גא מכאלף ללכאסרה 


\section{II.L.1.7.9.}

The eighth type of case that breaks the rule is the succession of two letters. If two bets or kafs, but not the remaining letters, succeed one another and under the first of them there is

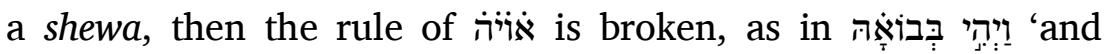

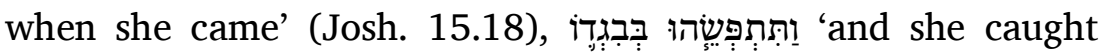

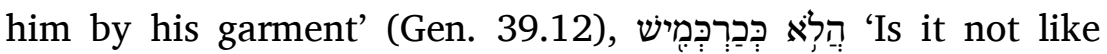
Carchemish?' (Isa. 10.9), and other cases. If a vowel occurs under the first of the two instead of shewa, the rule of

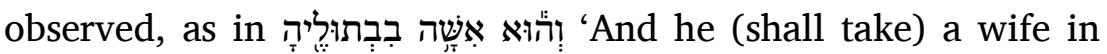

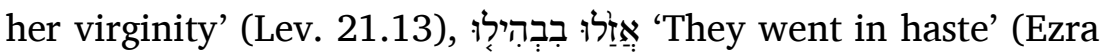
4.23), and similar cases.

\section{II.L.1.7.10.}

The ninth type of case that breaks the rule is bet and pe. The statement concerning them is similar to the statement regarding the preceding type of case that breaks the rule, without there being any disagreement. This is that when bet is followed by pe and shewa is below the bet, the rule of

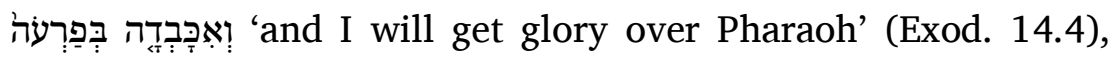

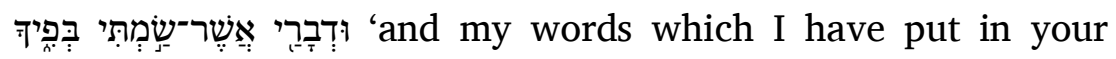
mouth' (Isa. 59.21), and similar cases. If a vowel occcurs instead of shewa, then the rule of אַוּיה is observed, as in will not look upon the rivers' (Job 20.17). I do not know any exception to this breaking of the rule.

\section{II.L.1.7.11.}

Take note that Ben Naftali, and perhaps some of those who preceded him, had a particular opinion about the dagesh of

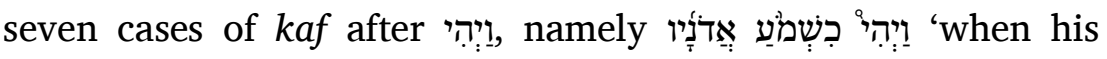

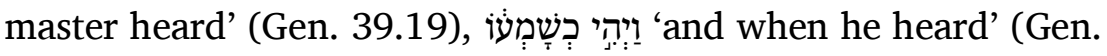


II.L.1.7.9.

אלכאסרה אלתאמנה חרפין מתראדפין כל באאין וכאפין תראדפא אלואחד בעד אלאכר מן דון >בקיה חרוף> בֹ̇דذפּ וכאן תחת אלאול מנהא שוא כסר שרט אלאוֹיוה מתל ויהי בּבואה ותתפשהו בּבגדו הלא ככרכמיש אלי גיר דלך פאן כאן תחת אלאול מנהמא מא עוץ (L1:17r) מן אלשוא מלך תבת שרט

אלאוֹיוּה כך והוא אשה בَבَתוליה אזל' בَבَהילו ומא שאכל דלך

II.L.1.7.10.

אלכאסרה אלתאסעה בא ופא אלכלאם פיהא כּלכלאם פי אלכאסרה אלתי קבלהא מן גיר כלף והו אן כל בא ובעדהא פא אדא כאן תחת אלבא שוא כסר שרט אלאוֹיוה כקול ואכבדה

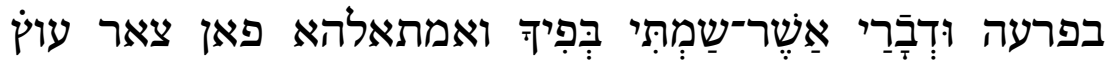
אלשוא מלך תבת שרט אלאויה כל אל ירא בَפלגות ומא ערפת עלי הדה אלכאסרה מסתתני

II.L.1.7.11. ואעלם אן בן נפתלי ולעל מן תקדמה קד ראי ראיה פי דגש i כאפאת בעד ויהי והי כּשמועַ אד כּשמעו כּראות כּראותו L1 ח 487 בקיה חרוף] S10:1v (short version) 


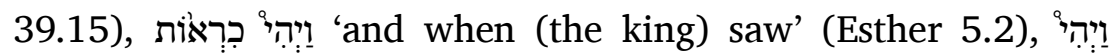

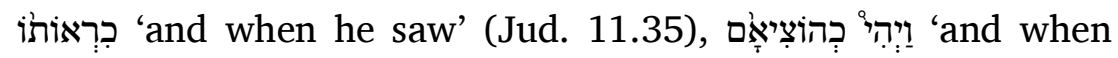

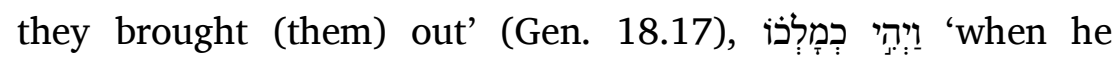

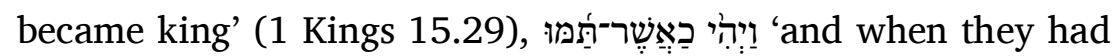
perished' (Deut. 2.16). ${ }^{7}$ According to him, each of the seven cases of kaf that occurs after וַיְי in Scripture has dagesh. This is known from his codices. Others, however, pronounce these rafe. I do not know for what reason Ben Naftali pronounced them with dagesh, for those who pronounce them rafe follow the principle of the influence of the soft letters. The reader, therefore, has two options. Either to read with the reading of Ben Naftali, in which case he must read all forms that he (Ben Naftali) reads, whether they be good readings or difficult readings, or to read with the reading of Ben Asher, which also is authoritative. If somebody reads what he deems to be the best reading of this one and of that one, he would (read) without any rule, because he deviates from the rationale of each of them.

\section{II.L.1.8. Section (on Further General Issues Relating to אiֹ)}

\section{II.L.1.8.1.}

Take note that the criterion of the (rule of) the letters and the letters should be based on the pronunciation and not

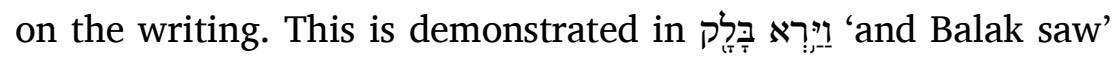

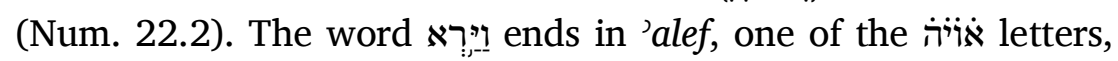
and (the next word) begins with bet, one of the ב̇דذذפت letters, but this letter is not pronounced rafe, despite the 'alef being adjacent to the bet and their being linked by the accent. The bet

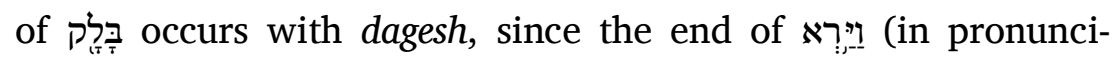

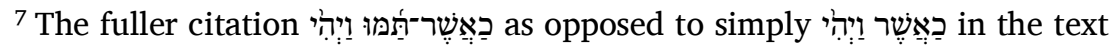
of Hidāyat al-Qāri' is given in Kitāb al-Khilaf (ed. Lipschütz, 1965, 19).
} 
כּהוציאם כּמלכו כּאשר ענדה אן כל ויהי פי אלמקרא יגי בעדה אחד הדה אלז כּאפאת אנהא תגי כלהא מדגושה ודלך מערוף מן מצאחפה וגירה ירפיהא ומא ערפת לאי עלה דגשהא בן נפתלי לאן מן רפאהא משא עלי אלאצל אלמוצוע פי תאתיר

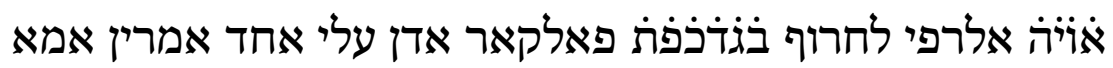
אן יקרא קראה בן נפתלי פילזמה אן יקרא גמיע מא יקראה מן מסתחסנאת (L1:17v) ומסתתקלאת ואמא אן יקרא קראה בן אשר ודלך איצא חכמה ואמא מן קרא מסתחסנאת הדא והדא פאנה יבקא בלא שרט לאנה יכרג ען עלה הדא והדא

פצל II.L.1.8. II.L.1.8.1. 510 אעלם אן אלמעול פי אוֹוּה ובגדذפֹ עלי אללפט לא עלי אלכט יביין דלך אן וירא בּּלק אכר וירא אלף מן אויה ואולה בא מן ב̇דֹذפּ ולם יגי אלחרף רפי מע אסתנאד אלאלף אלי אלבא ואכתלאטהמא באללחן ואנמא גא אלבא מן בלק מדגוש לאן מחט וירא אלריש לא אלאלף פצאר אלמעול עלי אללפט לא 
ation) is the resh not the 'alef, and the criterion is the pronunci-

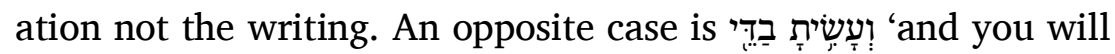

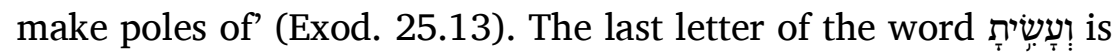
tav, but the bet is rafe. The reason for this is that when tav has qames, it is pronounced with two letters, and if you were to write וְעָשָׁיתָה in full orthography, it would have he. So the criterion is the pronunciation. The other cases of the breaking of the rule are also based on this principle, since this is the principle that forms the basis for the rule of

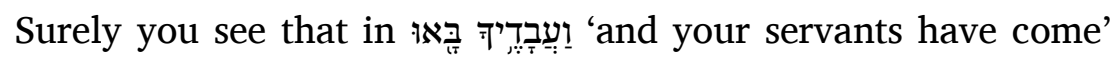
(Gen. 42.10) the bet occurs with dagesh on account of the breaking of the rule known as di-dhhiq.

\section{II.L.1.8.2.}

Perhaps somebody may ask why the letters what is after them to be rafe in accordance with the preceding discussion. The response could be that this is because these four letters are the letters of softness and prolongation, as has been stated by Yahyā ibn Dā' $\bar{u} d$ the Maghribī, the author of the Book of Prolongation and Softness, and letters that come after them that are not one of the letters of softness become soft due to their proximity. It may also be said that this is a custom adopted by the people of the language for a good reason known to them, and the knowledge of this has been transmitted by us and we read what we have received from the people of the language, and we should not abandon it until the people of the language come and we know the function of what they adopted as their convention. So whoever does not read according to the rule of אוنיה is ind reading incorrectly. Blessed is He who knows secrets (cf. Psa. 44.22). 
עלי אלכט ובאלעכּס מן דלך וְעָשִׁית בַָּּי אכר לפטה ועשית תו

וגא אלבא מרפי ואלעלה פי דלך אן אלתו אדא כאן מקמוצא כרג בחרפין ולו כתבת ועשיתה מלא כאן בהא פאלמעול אדן עלי אללפט וסאיר אלכואסר תתם פי הדא אלאצל לאנה הו

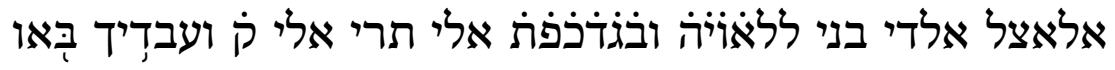
אן אלבא [יגי] מדגוש מן כאסרה דדחיק

II.L.1.8.2.

ולעל סאיל [יס]אל על חרוף אוּיוּה לם כאנת תרפי מא בעדהא עלי אלשרוח אלמדכורה פימכן אן יגאב אן למא כאנת הדה אלארבע חרוף הי חרוף אללין ואלמד עלי מא דכרה יחיי בן דאווד אלמגרבי (L1:18r) צאחב כתאב אלמד ואללין פילין מא בעדהא ממא ליס הו מן חרוף אללין ללמגאורה וימכן אן יקאל איצא אן הדא אצטלאח אצטלחו עליה אהל אללגה לגרץ צחיח עלמוה הם ואנשד ענא נחן עלמה פנחן נקרא מא תסלמנאה מן אהל אללגה ולא נכליה אלי אן יגו אהל אללגה פנעלם פאידה

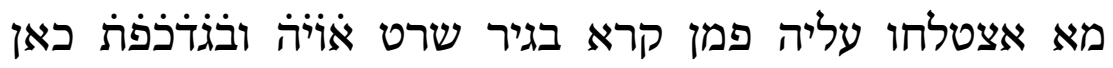
לאחנא וברוך יוָּע תעלומות 


\section{II.L.1.9. Chapter concerning Letters that Occur in Three Grades}

\section{II.L.1.9.1.}

Take note that just as there are among the letters those that when they are adjacent to another letter, the latter makes them light with rafe, likewise among the letters are those that occur in three grades with regard to heaviness and lightness. The first grade is lightening. The second is the normal dagesh. The third is the major dagesh. This includes the tav.

\section{II.L.1.9.2.}

Take note that the tav, unlike the other letters, may occur rafe,

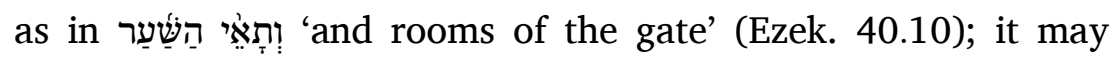
occur with dagesh, as in 'instead of bronze' (Isa. 60.17), תתוֹרי זָהָב 'ornaments of gold' (Cant. 1.11); and it may occur with major dagesh. The latter includes three tavs: 'He made it an eternal heap of ruins' (Josh. 8.28),

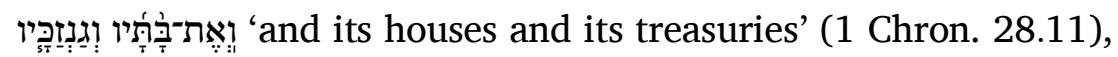

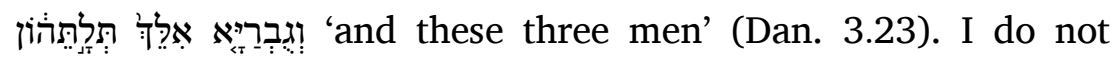
know anybody who differs (in reading) with regard to these

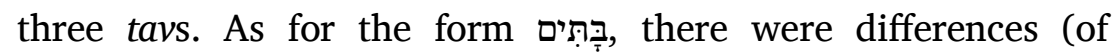
reading) with regard to it.

\section{II.L.1.9.3.}

Take note that the Tiberians said that they have a resh that is not read (in the same way) by anybody else. It is likely that the climate of their town caused this. It has the same status as the tav in the word according to the view of Ben Naftali, who gives it a grade in between two grades.

\section{II.L.1.9.4.}

The resh in their tradition is associated with specific letters, just

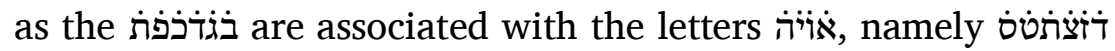




\title{
באב פי מא יגי מן אלחרוף עלי תלאתה מנאזל II.L.1.9.
}

\author{
II.L.1.9.1.
}

אעלם אן כמא גא פי אלחרוף מא אדא אסתנד אלי גירה כפפה ורפאה כדאך פי אלחרוף מא יגי עלי ג מנאזל פי אלתקל ואלכפה אלמנזלה אלא אלתכפיף אלذ אלדגש אלמעהוד אלג

II.L.1.9.2. אעלם אן אלתו מן דון סאיר אלחרוף קד יגי רפי כק ותָָהֵי השער וקד יגי דגש כקול תחת הנחשת תורי זהב וקד יגי דגש כביר והו

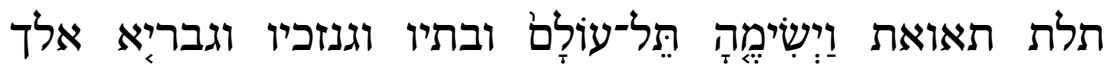

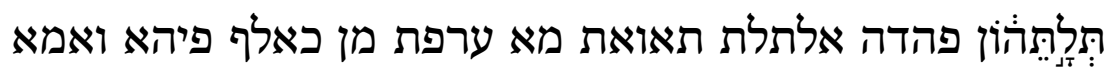

II.L.1.9.3. ואעלם אן אלטבראניין דכרו אן להם ריש לא יקראה גירהם ואלקריב אן הוא בלדהם יפעלה והו יגרי מגרי אלתו פי לשון בתים עלי ראי בן נפתלי אלדי יגעלה הו מנזלה בין מנזלתין

II.L.1.9.4.

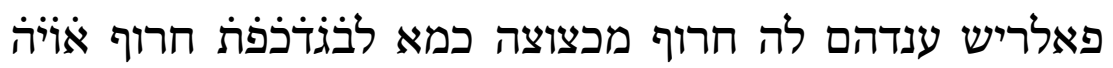

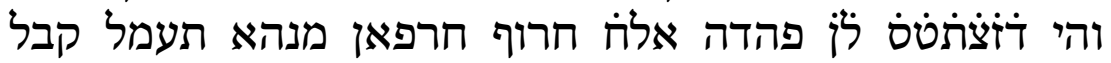


and לj. Two of these eight letters operate both before the resh and after it, namely $i$, and the six other letters before the resh. The eight letters affect the resh only when shewa is under it or (when shewa is) under the eight letters that are specific to it.

\section{II.L.1.9.5.}

The light resh in their tradition is (in words) such as 'Harness the chariot!' (Micah 1.13), רִסִיסֵי לִיָָלָ 'ddrops of the night'

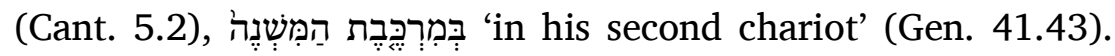
Such cases and similar ones are their normal pronunciation of the letter, for they consider it to be the light resh.

\section{II.L.1.9.6.}

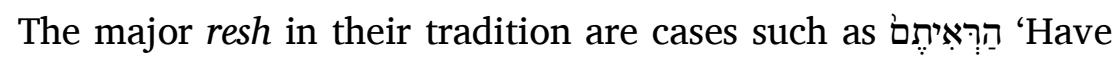
you seen?' (2 Kings 6.32), הַרְעָמָזָה 'to irritate her' (1 Sam. 1.6), and the like.

\section{II.L.1.9.7}

The grade between two grades (of the resh) where dalet precedes

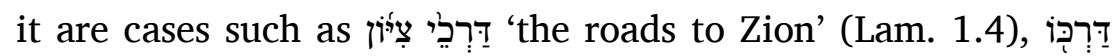
'his way' (Gen. 24.21), לִדרְאוֹ 'to contempt' (Dan. 12.2). Cases

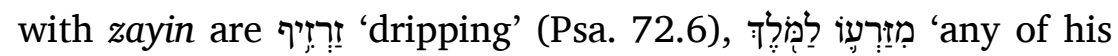
offspring to Molech' (Lev. 20.2), יזרי 'He scatters' (Isa. 28.25).

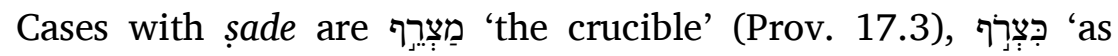

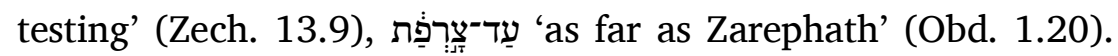

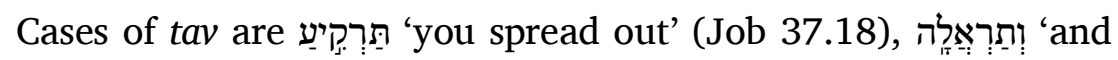
Taralah' (Josh. 18.27), תַרְבָּיע 'you will (not) cause to breed' (Lev.

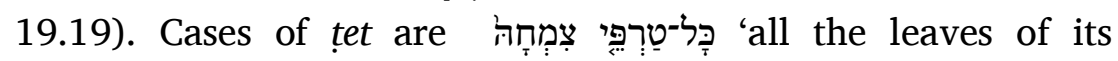

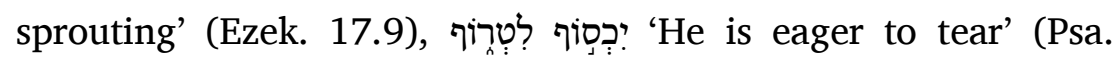

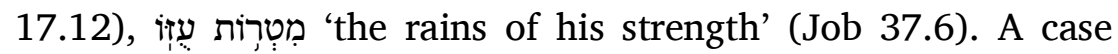

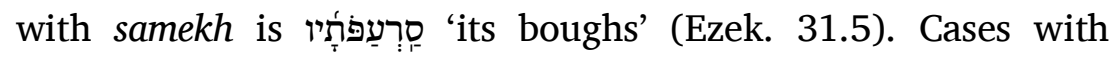


אלריש ובעדה והמא לן ואלסתה חרוף מן קבל אלריש והדא

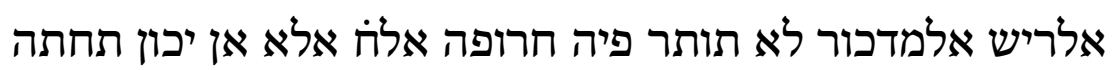
שוא או תחת חרופה אלח [אל]מכצוצה בה אלמדכור תותר פיהופריה

$$
\text { II.L.1.9.5. }
$$

פאלריש אלכפיף אלדי להם מתל רְתם המרכבה רסיסי לילה במרכבת המשנה פהדא ומא שאכלה מא כלאמהם עליהא לאן הדא ענדהם הו אלריש אלכפיף

II.L.1.9.6. ואלריש אלכביר ענדהם הו הראיתם הרעימה ואמתאלהמא

ואלמנזלה בין מנזלתין ממא קבלה [אלד]אל כק דרכי ציון דרכו

לדראון ואלזאי זרזיף מזרעו למולך > יזרוק> אלצדי מַצְרָף

[כ]צרוף עד צרפת אלתו תרקיע ותראלה תרביע טית כל טרפי

צמחה יכסוף לטרוף מטרות עזו אלסמאך סרעפותיו אללמאד 


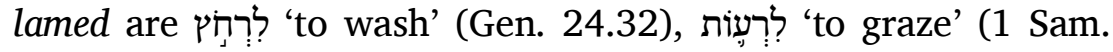

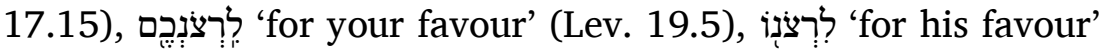
(Lev. 1.3). Cases with nun are סַרְרִָּּי 'rulers of' (Josh. 13.3) 'my nard' (Cant. 1.12). They call these cases and similar ones a grade (of resh) between two grades, namely (the grades of) dagesh and rafe. Whoever investigates this carefully (will see that) it is as they say, since the difference is clear between the

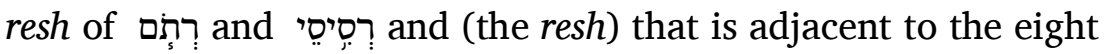
letters (preceding it) when they have shewa under them or when shewa is under it. Its heaviness is clear compared to the lightness of the resh of רֶּ and the like.

\section{II.L.1.9.8.}

It has been stated previously that I do not know anything that I can report about the zāy makrūkh. I only mentioned it so that it be known that letters have different attributes and because speech is dependent on letters.

\section{II.L.1.10. (Conjugations)}

Take note that the people of the language made the conjugations of the language in four categories: from one root letter, such as הְַּּנה 'build' and the like, from three letters, such as שממר and the like and from four letters, such as 'wrap', and the like. A letter may also change position in a word with the result that its meaning changes. I shall mention here the phenomenon of change of position in one word as an example: עֶרֶ with three letters from 'becoming evening', עָרֵב לָאִישיש 'sweet to a man' (Prov.

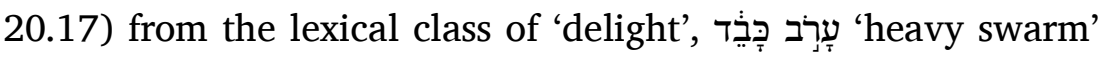
(Exod. 8.20) from the lexical class of 'mixing', ערָּב לְמִינוֹ '(every)

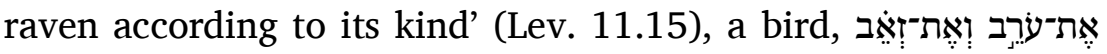
'Oreb and Zeeb' (Jud. 7.25), the name of a man. When you 
לרחוץ לרעות לרצונכם לרצונו אלנון סרני נרדי פהדה אלאמתאל ואשבאההא יסמונהא מנזלה בין מנזלתין והמא אלדגש ואלרפי ומן תאמל דלך כאן כמא דכרו אד (L1:19r) אלפרק 560 אדא כאן תחתהא או תחתה שוא ותקלה טאהרא ענד כפה ריש רתם ומא מאתלה

II.L.1.9.8. וקד תקדם אלקול אן אלזאי אלמכרוך מא ערפת פיה שיא

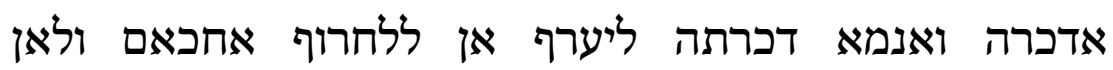

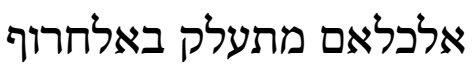

II.L.1.10. (L3:8r) אקסאם מן חרף ואחד אצלי מתל הַכֵה ונחוה ומן חרפין מתל בנֵה ונחוה ומן ג מתל שְמר ונחוה ומן ד מתל כרבל ונחוה ואלחרף איצא קד תתקלב פי אללפטה ותתגאיר מעאניהא 570 פאדכר מן גנס אלתקליב לפטה ואחדה לתכון נמודגא עֶרֶב ג חרוף מן אלגרוב עָרֵב לאיש מן לגה אללדה (L3:8v) עָרב כבד מן לגה אלאכתלאט ערבב למינו טאיר ערבב וזאב אסם רגל ואדא 
change the position of their letters, they become בִּרָ 'Bera' (Gen. 14.2), the name of a man, רבֵּע 'a 'stupidity' from

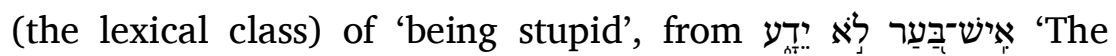

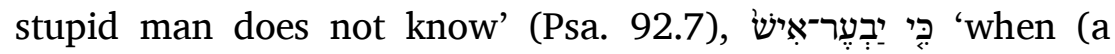
man) causes (a field or vineyard) to be grazed over' (Exod. 22.4) from the lexical class of 'trampling, befouling with dung', 'He ignited fire' (Jud. 15.5) from the lexical class of

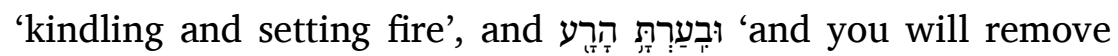
the evil' (Deut. 13.6, etc.) from the lexical class of 'removing'.

\section{II.L.1.11. Chapter concerning the Occurrence of Letters for the Sake of Enhancement}

\section{II.L.1.11.1.}

Take note that you do not find in the Bible a word that consists

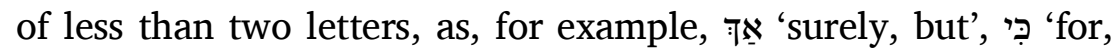

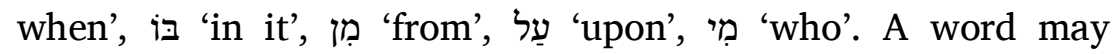
consist of three letters, for example, שְׁמו 'keep', זְכר 'remember',

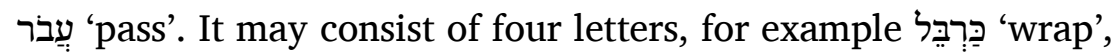

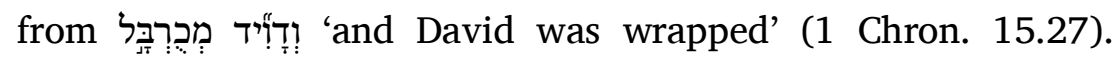
Expressions may be constructed from five up to eleven letters. We have not found more than that number. This is found in only

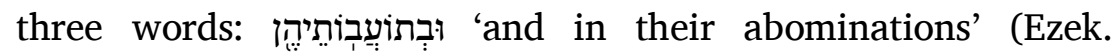

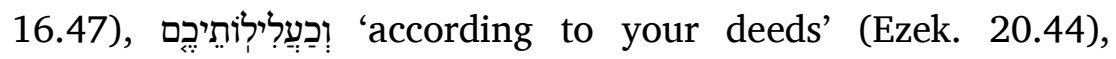

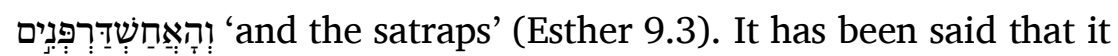
would have been possible for the people of the language to use

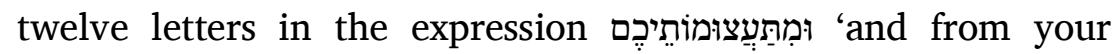

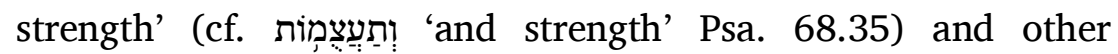
expressions according as the need may have arisen. As for words of two letters, when you move the first to the (position of) the last and the last to the (position of) the first, they turn out to be a functional part of speech consisting of two parts, for example, 
אקלבתהא גת בֶרֶע אסם רגל [ר]בֶע רְבע בֶעֶר מן אלתגאהל מן איש בער לא ידע כי יבער איש מן לגה אלתבאער ויבער אֵש מן לגה אלאחראק ואלאשעאל ובערת הרע מן לגה אלנפי

II.L.1.11.

בוֹ מִן עַל מִי ותכון מן ג̇ כק שמר זכר עבר ותכון מן ֹֹ כרבל מן

ודוד מכרבל ותנבני אלאלפאט מן ה ומא זאד אלי יא ומא וגדנא 580 אזיד מן דלך והו ג אלפאט פקט ובתועבותיהן וכעלילותיכם והאחשדרפנים וקד קיל אן ימכן אן יסתעמלו אהל אללגה יב חרפא פי לפטה ומתעצומותיכם וגיר דלך ממא תדעוהם אלחאגה אליה ומא כאן מן אלכלם מן חרפין אדא נקלת אלאול אלי אלאכיר ואלאכיר אלי אלאול תכון עלי אלקסמין כלאמא 


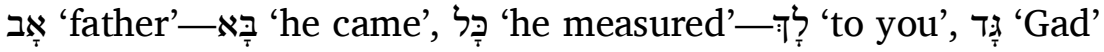

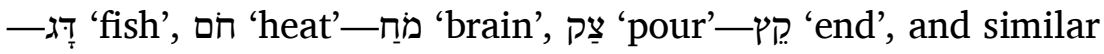
cases.

\section{II.L.1.11.2.}

An expression consisting of two or more letters may be enhanced. Enhancement includes various different types. A noun

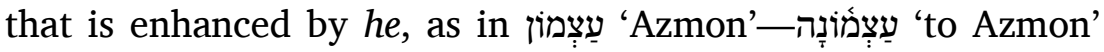

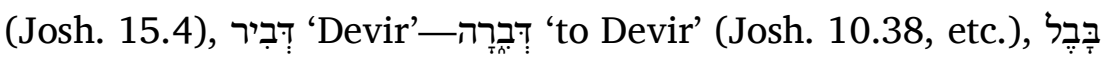

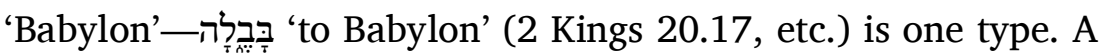
second type is where a feminine noun ending in he is enhanced

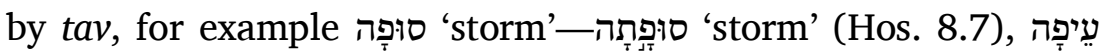
'darkness'— עִיפָּתָה 'darkness' (Job 10.22), ישוֹעָה 'salvation'-

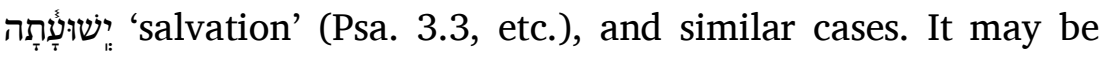

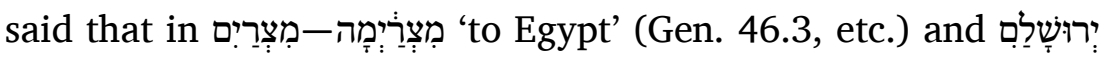

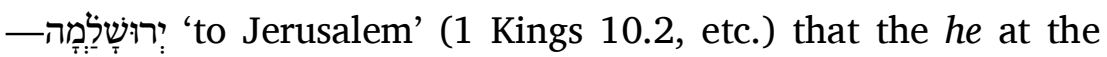
end of the word is in place of 'to'. A verb may also be

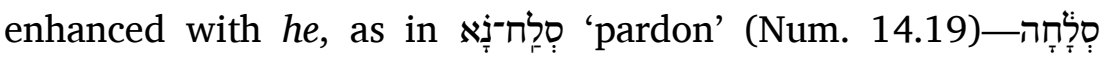

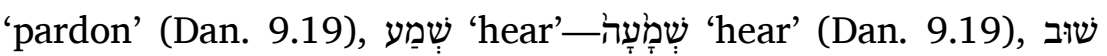

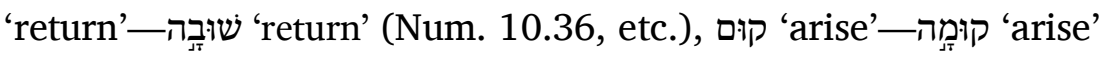
(Num. 10.35, etc.).

\section{II.L.1.11.3.}

Inflected nouns may be enhanced by yod, for example הِיنשֶׁ 'the one sitting' (Psa. 123.1), הַהפְְִּ 'the one who changes' (Psa.

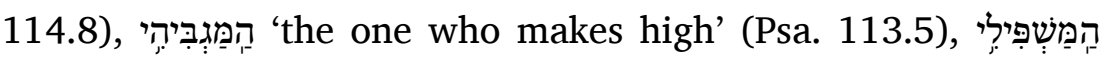
'the one who makes low' (Psa. 113.6). Feminine nouns may also

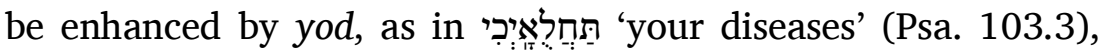

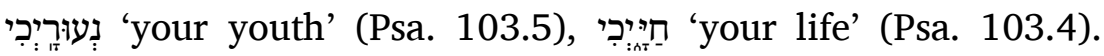

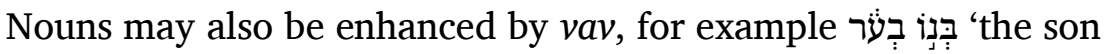


מסתעמלא (L3:10r) מתל אָב בָא כָל לָד גָּד דָג חם מחח צַק קֵץץ

ואמתאל דלך

II.L.1.11.2.

פאללפט אלדי הו מן חרפין ומא זאד יפכם ואלתפכים עלי וגוה

פאלאסם אלדי יפכם באלהא מתל עצמון עצמונה דביר דבירה

בבל בבלה וגה ذ והו אדא כאן אלאסם מונת בהא קד יפכם

בתָ[י] מתל סופה סופתה עיפה עיפתה ישועה ישועתה ואמתאל

דלך וקד יקאל אן מצרים מצרימה ירושלם ירושלמה אן אלהא

פי אכר אלאסם מקאם אֶל ואלפעל יפכם באלהא איצא מתל סלח נא סלָחחה שמַע שֶמָעָה שוּב שובָה קום קומָה

II.L.1.11.3.

ואלאסמא אלמתצרפה פקד תפכם באליוד הישבִי ההוֹפכי

המגביהי המשפילי ואלאסמא אלמונתה קד תפכם איצא באליוד

מתל תחלואיכיכי נעוריְכי חייְכי ואלאסמא איצא תפכם בואו מתל 


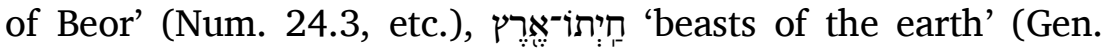

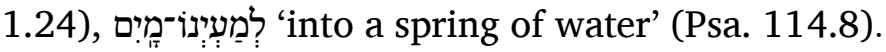

\section{II.L.1.11.4.}

Functional particles may be enhanced by yod, for example

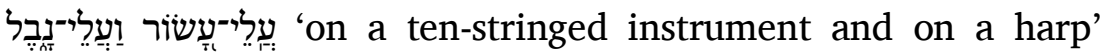

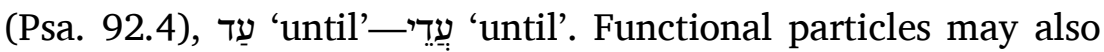
be enhanced by mem and $v a v$, for example strengthen you with my mouth' (Job 16.5), the virtual form of

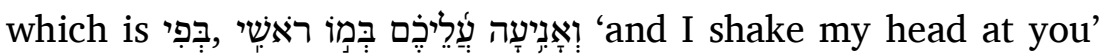

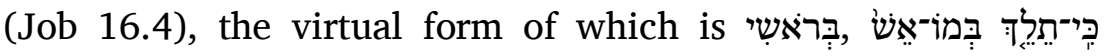
'when you walk through fire' (Isa. 43.2), the virtual form of

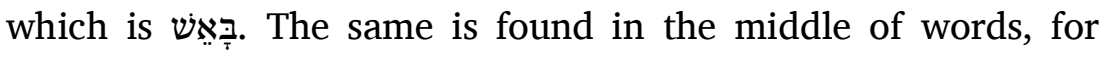

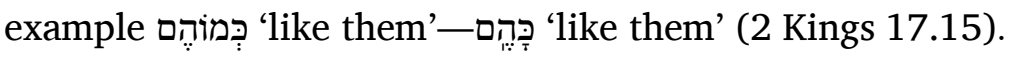

\section{II.L.1.11.5.}

Take note that somebody who has discussed enhancement has

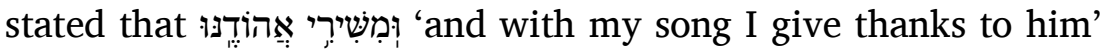
(Psa. 28.7) is enhanced by he, and that if it was not enhanced, it

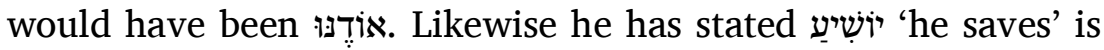

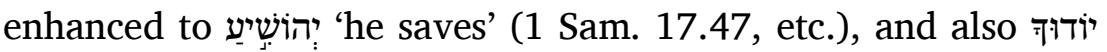

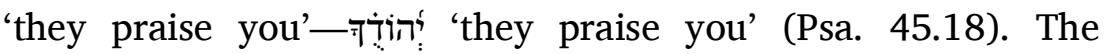
situation is not, however, as he states, because the imperative forms are הiֹשֵׁע and it is the rule that the (prefixed) letter of the future is attached to the imperatives of active verbs,

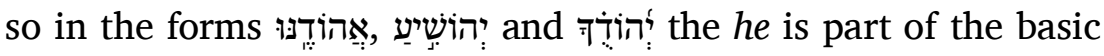
structure and it is not a he of enhancement. Since, however, the people of the language regarded this as heavy, they elided the hes in such forms, in order to make the word lighter. You will find this explained in the books of the grammarians. 
בנו בעור חייתו ארץ למעינו מים

II.L.1.11.4.

ותפכם אלכואדם באליוד מתל עלי עָשור וַעַלֵי נָבל עַד עַדִי

ותפכים איצא אלכואדם במאם וואו מתל אאמצכם במו פי

600

במו אש תקדירה בָאש ומתל דלך פי וסט אלכלאם כמוהם כהם

II.L.1.11.5.

ואעלם אן מן תכלם פי אלתפכים קאל אן ומשירי (L3:10v) אהוֹדֶנו הו מפכם בהא ולו לם יפכם כאן אודֶנו ומתלה קאל יושִיעֶ יפכם יהוֹשִיעַ וכדלך יודוך יהודוך וליס אלאמר כמא דכר לאן אלאמר 605 ממא יסמא פאעלה פאדא קאל אהודנו יהושיע יהודוך אלהא קרת מקרהא פליס הי הא תפכים ואנמא למא אסתתקל דלך אהל אללגה חדפו אלהאאת ממא מאתלהא אסתכאפא ללכלאם והדא תגדה פי כתב אללגויין מביינא 


\section{II.L.1.11.6.}

Verbs may be enhanced by a vav at the end of the word, for

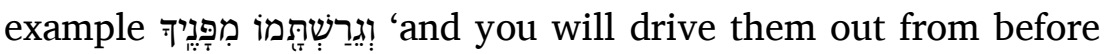
you' (Exod. 23.31), the virtual form of which is

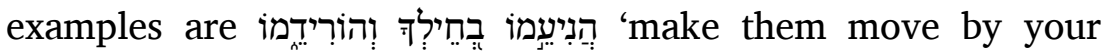

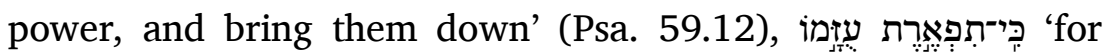
(you are) the glory of their strength' (Psa. 89.18), and further cases.

\section{II.L.1.12. Section}

\section{II.L.1.12.1.}

One person who has discussed enhancement has said that identical successive letters are enhanced in (ways that fall into) two categories. The first category is (an enhancement) of a letter by another identical letter, whereby they become two letters. The second is (an enhancement) of two letters by two identical adjacent letters, whereby they become four.

\section{II.L.1.12.2.}

Examples of the first category include the following. Bet: עוֹד ינוּבוּוּ : 'They still bring forth fruit' (Psa. 92.15), which does not

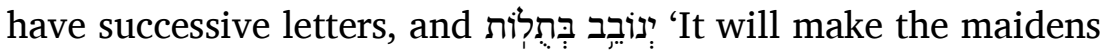

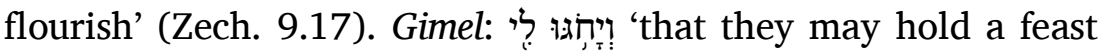

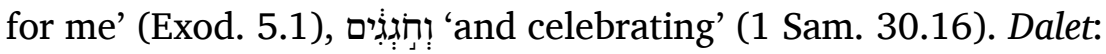

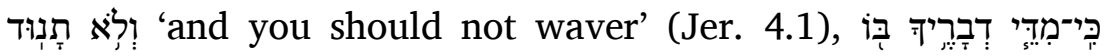

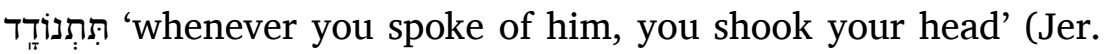

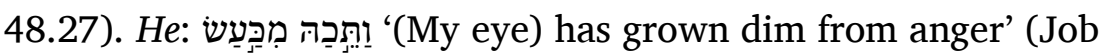

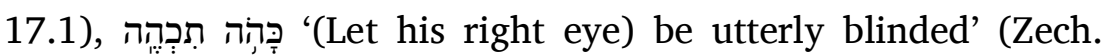

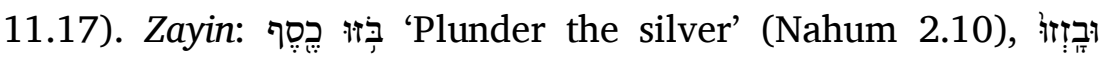
את 'and they will plunder those who plunder them' (Ezek.

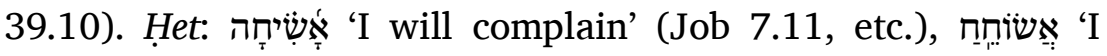

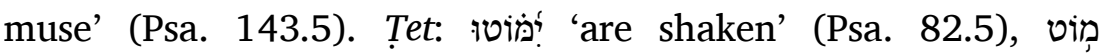


II.L.1.11.6.

610 וקד תפכם אלאפעאל פי אכר אלכלאם בואו כק וגרשתמו

מפניך תקדירה וגרשתם ומתלה הניעמו בחילך והורידמו כי

תפארת עזמו אלי גיר דלך

פצ'II.L.1.12.

II.L.1.12.1.

קאל מן תכלם פי אלתפכים אן אלחרוף אלמתראדפה תפכם 615 עלי קסמין אלקסם אלואחד חרף לחרף מתמאתלין פיצירא חרפאן אלذ חרפין לחרפין מתגאורה פיצירון ארבעה

II.L.1.12.2.

אלקסם אלאול אלבא עוד ינובון גיר מתראדף ינובב בתולות

מתראדף אלגמאל ויחגו לי וחוגגים אלדאל ולא תנוד כי מדי

דבריד בו תתנודָד אלהא ותֵֶֶה מכעס (L1:20v) כהה תכהה אלזאי

620 


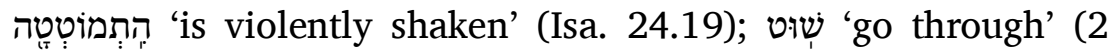

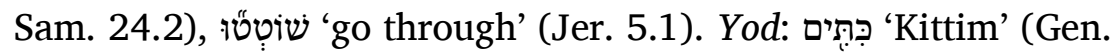

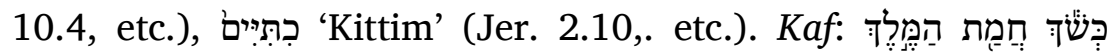

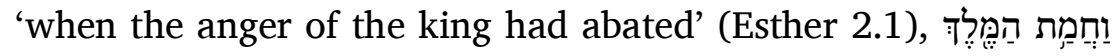
'The anger of the king abated' (Esther 7.10). Lamed:

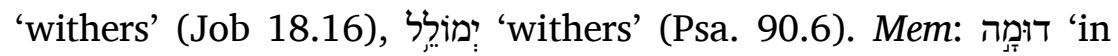

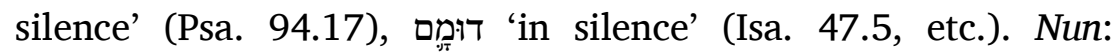

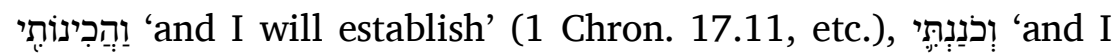
will establish' (2 Sam. 7.13). Samekh: לָרָָ 'to moisten' (Ezek.

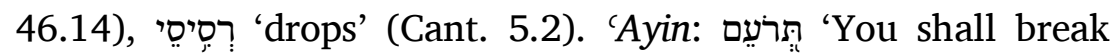

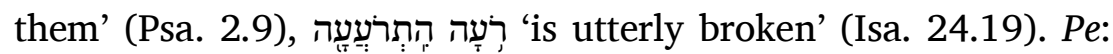

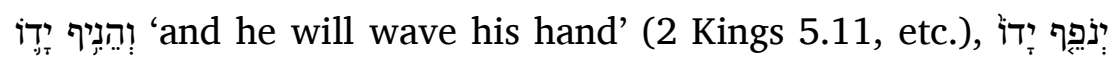

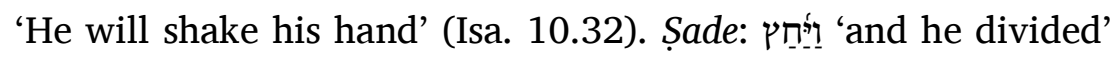

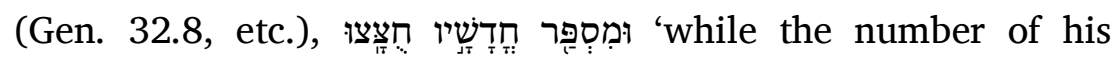

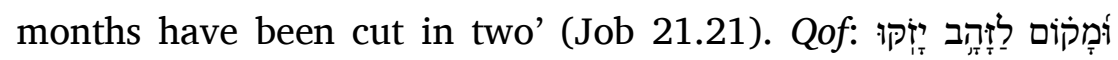
'and a place for gold that they refine' (Job 28.1), מִזְזָ 'refined' (1 Chron. 28.18, etc.). Resh: ארוֹ ארוֹ 'Curse Meroz' (Jud. 5.23),

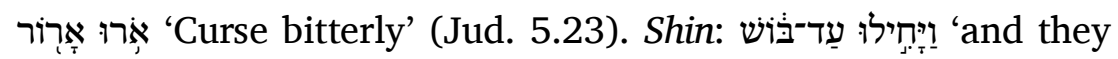
waited until they were disappointed' (Jud. 3.25), בּنِשׁ 'He

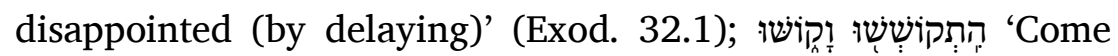
together and hold assembly' (Zeph. 2.1). Tav: יתת 'will be broken' (1 Sam 2.10, etc.), וְהַחְת 'and I will cause to be dismayed' (Jer. 49.37). These are examples of a letter being followed by another letter to form two (identical) letters.

\section{II.L.1.12.3.}

Now, the second category, in which two letters follow two

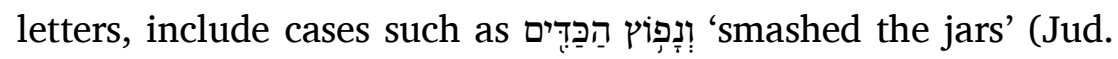

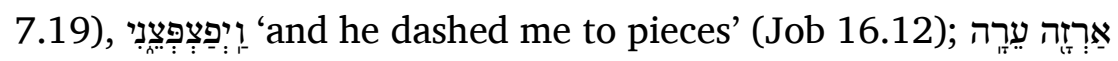

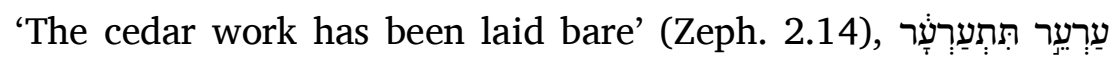


מוט התמוטטה שוט שוטטו אליוד כתים כתיים אלכאף כשך ז וחמת המ שככה אללמאד ימל ימוֹלֵל אלמאם דומה דומם אלנון והכינותי וכוננתי אלסמאך לרס רסִיסֵי אלעין תרועם רעה התרועעה אלפא והניף ידו ינופף ידו אלצדי ויחץ מספר חדשיו חְצָצוּ אלקוף ומקום לזהב יזָקו מזקק אלריש ארו מרוז ארו ארור

אלשין ויחילו עד בוש בושש התקוששו וקשו אלתו יחתו והחתתי פהדה מן תראדף חרף לחרף פצאר חרפין

II.L.1.12.3. והדא אלקסם אלذ והו מא יתראדף חרפין לחרפין ונפיץ > הכדים> ויפצפצני ארזה ערה >ערער> תתערער אלי גיר דלך 
'will be laid utterly bare' (Jer. 51.58), and other cases, which have been stated to be enhancement by a scholar who has discussed enhancement. Note, however, according to the diqduq scholars this is not enhancement. This is because the meaning (of a word) can be fully expressed without a letter of enhancement and also (a letter of enhancement) is not a fixed component of a conjugation. These scholars fall into two groups. Some of them consider it (i.e. the enhanced letter in the examples above) to be a root letter due to the fact that it is a fixed component of the conjugation. Others call it an auxiliary letter and do not consider that it should be called a root letter, since one may utter (inflections of) the lexical class without it, but not in the way that (inflections of) a lexical class are uttered without a letter that is for the purpose of enhancement.

\section{II.L.1.13. Chapter on Contraction}

Take note that he may occur for the sake of enhancement without expressing meaning and, conversely, it may be contracted, being indicated only by the grammar, and retain the meaning of he. It is contracted after 'alef, as in

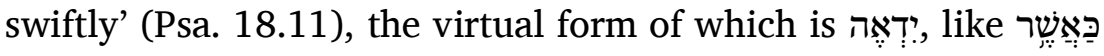
ידֵֶ: 'as (the eagle) flies swiftly' (Deut. 28.49), its imperative

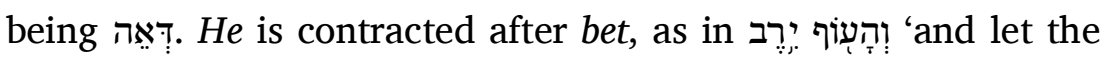
birds multiply' (Gen. 1.22), the virtual form of which is ?ִ:ִ,

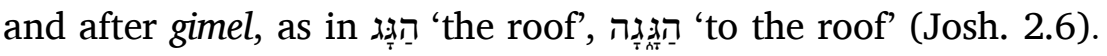

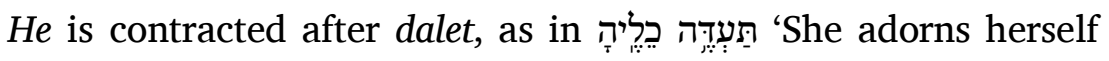

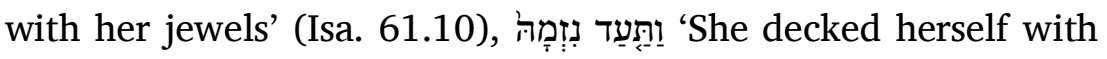
her ring' (Hos. 2.15). It is contracted after he: תִכְֶהָ 'will be

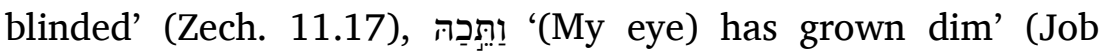

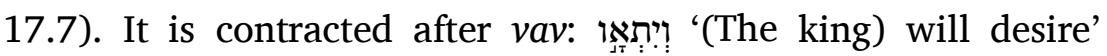


ממא קאלה מן תכלם פי אלתפכים אנה תפכים ואעלם אן

אלדקדוקיין ליס הדא ענדהם תפכים לאן חרף אלתפכים יתם אלגרץ מן דונה ואיצא פלא יתבת פי תצריף והם עלי קסמין מנהם מן יגעלה חרף אצלי לתבותה פי אלתצריף ומנהם מן יסמיה מסתעמל [ולא ירי] אן יסמיה אצלי לאן קד יתכלם באללגה מן דונה לא עלי אלוגה אלדי (L3:1v) יתכלם באללגה מן דון אלחרף אלדי ללתפכים

II.L.1.13. אעלם אן אלהא תגי ללתפכים ולא יטהר להא מעני ותגי בעכס דלך והו אן תכתצר ותדל עליהא אללגה ויכון להא מעני אלהא 640 קד תכתצר בעד אלאלף כק וידא תקדירה וידאה מתל כאשר ידאה אלאמר מנה דאֵה ויכתצר אלהא בעד אלבא מתל והעוף ירב ותקדירה יִרְבַה ובעד גמאל [הג]ג הגגָה ויכתצר אלהא בעד אלדאל מתל תעדה כ[ליה] ותעד נזמה ויכתצר בעד אלהא תִכְהַה וּתֵכַה ויכתצר בעד אלואו ויתאו ויתאוה ויכתצר בעד 
(Psa. 45.12), Iִיִ 'and he longed' (2 Sam. 23.15). It is

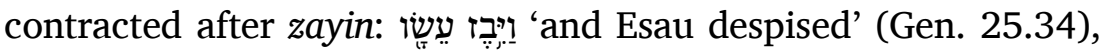
'God, you will not despise' (Psa. 51.19). It is

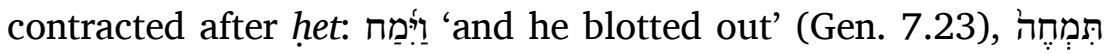
'You will blot out' (Deut. 25.19). It is contracted after tet: יִינ, 'and he stretched' (Gen. 29.21, etc.), יטֵּה יָּדו' '(The Lord) stretches

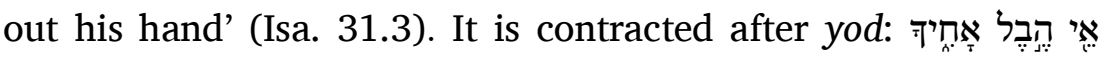
'Where is Abel your brother?' (Gen. 4.9), אֵיָה| חְסָסָדיָ 'Where is your loving kindness?' (Psa. 89.50). It is contracted after kaf:

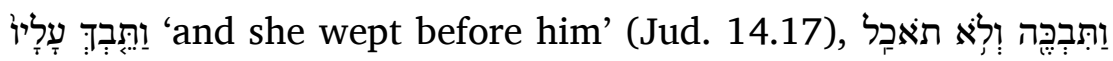
'and she wept and did not eat' (1 Sam. 1.17). It is contracted

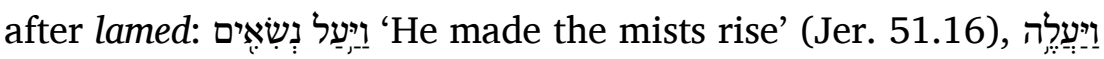
נִשֶׁאים 'and he made the mists rise' (Jer. 10.13). It is contracted

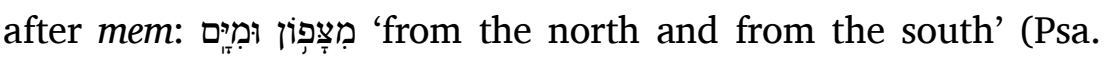

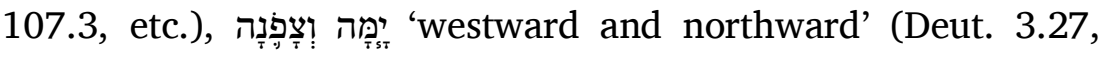

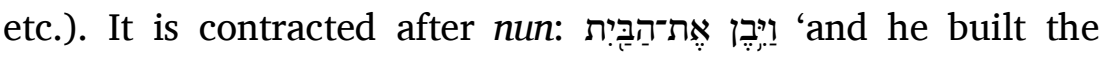
house' (1 Kings 6.9), וַיְְִּנה 'and he built' (Josh. 19.50). It is

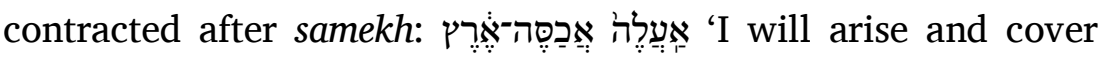

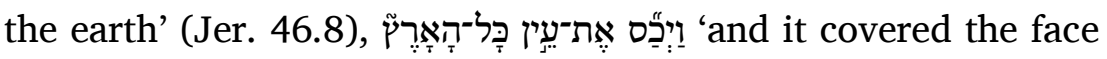
of the whole land' (Exod. 10.15). It is contracted after 'ayin: I-

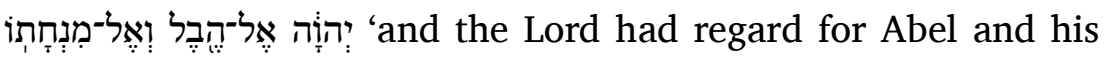

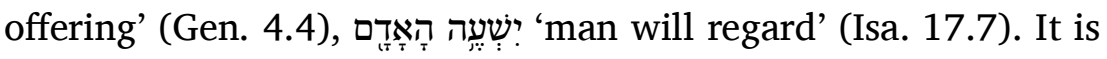

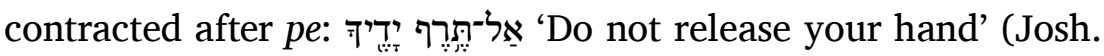

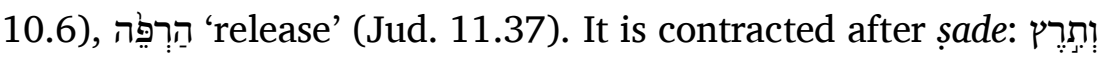

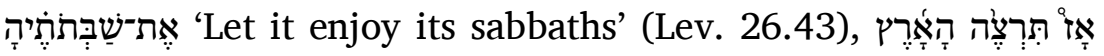
'Then the land will enjoy' (Lev. 26.34). It is contracted after qof:

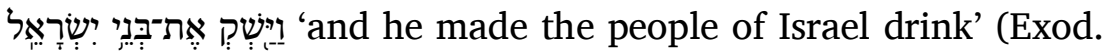

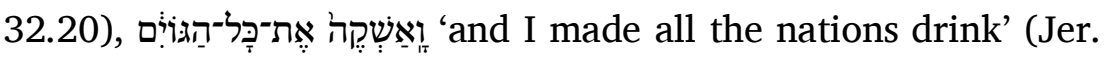

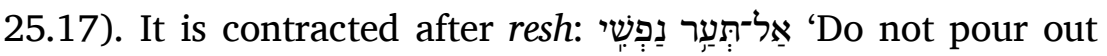

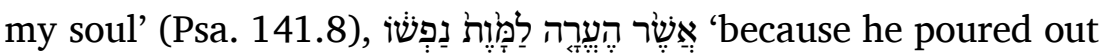
his soul to death' (Isa. 53.12). It is contrated after shin: "דָבַר־אִיש יְּוּדָה 'The words of the men of Judah were harder' (2 
645 אלזאי ויבז עשו אלהים לא תבזה ויכתצר בעד אלחית וימח תמחַה ויכתצר בעד אלטית ויט יטה ידו ויכתצר בעד אליוד אי הבל אחיך איה חסדיך ויכתצר בעד אלכאף ותֵבְך עליו ותבְכַּה ולא תאכַל ויכתצר בעד אללמאד ויעל נשיאים ויעלה נשיאים ויכתצר בעד אלמאם מצפון ומים ימה וצפונה ויכתצר בעד אלנון 650 ויבן את הבית ויבנה ויכתצר בעד אלסמאך אעלה אכסה ארץ ויכס את עין כל הארץ ויכתצר בעד אלעין וישע ייי אל הבל ואל מנחתו (L3:12r) ישעה האדם ויכתצר בעד אל[פ]א אל תרף ידי[ד] הרפה ויכתצר בעד אל[צ]די ותרץ את שבתותיה אז תרצה הארץ ויכתצר בעד אלקוף וישק את בני יש ואשקה את כל 655 הגוים ויכתצר בעד ריש אל תער נפשי אשר הערה למות נפ[שו] ויכתצר בעד אלשין ויקש דבר איש יהודה לא יקשה 


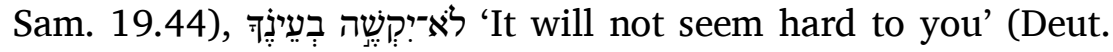

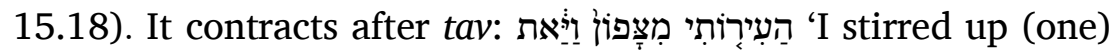

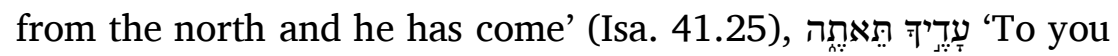
it will come' (Micah 4.8). (To these can be added) other examples of this type.

This is what needs to be said in the discourse on the letters. It is finished, much praise be to God. 
בעיניך ויכתצר בעד אלתָו העירותי מצפון וישֶאת עדיף תֵאתֶה אלי גיר דלך מן הדא אלגנס

פהדא מא לאח אן ידכר פי מקאלה אלחרוף תמת ואלחמד ללה 660 


\section{II.L.2.0. \\ THE SECOND DISCOURSE}

\section{II.L.2.1. (Preliminary Remarks on Vowels)}

\section{II.L.2.1.1.}

Discussion concerning the 'kings'. If you wish, you may say concerning the 'melodies', and if you wish, you may say concerning the 'inflections'. The meaning of these is the same. ${ }^{8}$ Four preliminary issues will be presented at the beginning of this section. Some of these have already been mentioned previously.

\section{II.L.2.1.2.}

The first is that speech cannot begin with a 'melody' (vowel), i.e. a 'king' (vowel). Rather it must begin with a letter. This is because when somebody begins speaking, the first component of his speech that is heard is one of the letters. He cannot begin with one of the vowels without putting a letter before it.

\section{II.L.2.1.3.}

The second is that when somebody begins (speech) with a letter, he must attach vocalic articulation ('i $(r a \bar{b})$ to this, since the letter cannot be deprived of this when it is the beginning (of speech).

\section{II.L.2.1.4.}

The third is that if somebody utters a word consisting of two letters that appear in speech, ${ }^{9}$ a vowel must come between

\footnotetext{
${ }^{8}$ I.e. they refer to the vowels. ${ }^{9}$ I.e. letters that are consonants and not 'soft' vowel letters.
} 


\section{II.L.2.0. \\ אל מקאלה אלתאניה}

II.L.2.1.

II.L.2.1.1.

אלכלאם פי אלמלוך ואן שית אן תקול פי אלנגמאת ואן שית תקול פי אלאנחא פאלמעני פי דלך ואחד יקדם להדה אלמקאלה ארבע מקדמאת ממא קד דכר טרף מנה פימא

II.L.2.1.2.

אלאול אלנטק לא יכון אבתדאה ואולה נגמה אעני מלך ואנמא

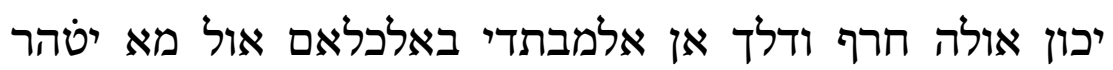

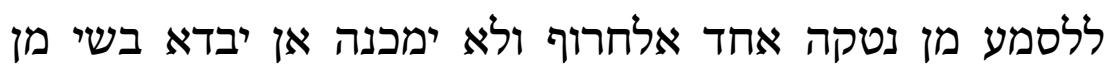

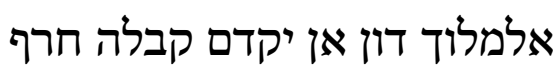

II.L.2.1.3. 670 ואלתאני הו (L3:12v) אן אדא אבתדא בחרף לא בד מן אן יתבעה אעראב אד לא יגוז אן יערא אלחרף מן דלך אדא כאן אבתדא

II.L.2.1.4.

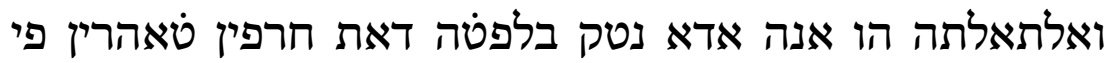

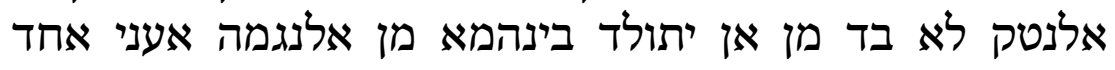




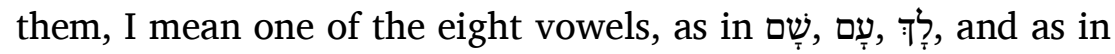
稚, ${ }^{10}$ and similar cases.

\section{II.L.2.1.5.}

The fourth is that the vowels always belong to the letters and the letters do not belong to vowels. This is because the vowels cannot function without letters. A letter may be deprived of a vowel but a vowel may not be deprived of a letter. This is because speech must consist of quiescent and mobile components and a mobile component is only made mobile by a vowel, whereas a quiescent component dispenses with this, as will be described in what follows.

\section{II.L.2.2. Chapter concerning the Number of the Vowels and those of them that are 'High', those of them that are 'Level' and those of them that are 'Low', and what is Connected to this}

\section{II.L.2.2.1.}

What is to be said concerning the vowels is manifest and clear, and not obscure, because it is through them that the purpose of a speaker is understood, and without them speech would be nonsense. Surely you see that in the original establishment (of language) by convention they were indispensable. This is because the origin of language was with Adam, peace be upon him. Either at the beginning the angels and he established language by mutual convention ${ }^{11}$ or they taught him language. It is not possible that God, may He be exalted, established

\footnotetext{
${ }^{10}$ This word consists of two consonantal radicals, viz. $\zeta$ and $T$, the inflectional prefix being ignored. | ${ }^{11}$ Literally: The angels established language by convention with him and he established it by convention with them.
} 
אלתמאניה נגמאת מתל קוֹ שָם עָם לָד וכקוֹ וילַד ואמתאל דלך

II.L.2.1.5.

ואלראבעה הו אן אלמלוך אבדא תאבעה ללחרוף וליס אלחרוף תאבעה ללמלוך לאן לא תפיד אלמלוך מן דון אלחרוף ואלחרף קד יערי מן נגמה ואלנגמה לא תערי מן חרף לאן אלנטק לא בד לה מן סאכן ומתחרך פאלמתחרך לא יתחרך אלא בנגמה ואלסאכן מסתגני ען דלך עלי מא יגי דכרה פי מא בעד

(L5:2r) II.L.2.2. 680 באב פי עדד אלנגמאת ומא מנהא רפע ומא מנהא נצב ומא מנהא כפץ ומא יתצל בדלך פוד

\section{II.L.2.2.1.}

אלכלאם פי אלמלוך טאהר L5:2v) גלי גיר כפי לאן בהא יפהם ען אלמתכלם גרצה ולולאהא לכאן אלכלאם עבתא אלי תרי אן פי אצל אלמואצעה לא בד מנהא ודאך אן אצל אללגה מע אדם על 685 אלס אמא אן תכון אלמלאיכה ואצעתה אללגה וואצעהא אבתדא או עלמתה אללגה תעלימא ואלמלאיכה לא יגוז אן 
language by convention with the angels, because the establishment by convention requires the pointing to the thing for which language is conventionally established. Pointing can only be undertaken with a limb, but He, may He be exalted, transcends the need to have limbs. If somebody were to say that He could have created a limb with which to establish (language) just as He could have created an instrument for speech, with which He could speak, (the response would be): but He must have taught them language to some extent for the sake of His first speech,

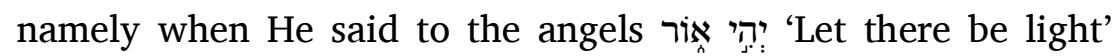
(Gen. 1.3), and He caused this to happen after this speech and thereby obliged them to recognize that 'light' is the name of what came into being after the speech and they learnt this. Then other items (of language) followed a similar course. He would have helped them receive and retain (language) from the first instance.

\section{II.L.2.2.2.}

When He said יהָיi, the shewa in it under the yod must of necessity have been pronounced mobile and the hireq must have been pronounced under the he, so that יִיָ: was a future form.

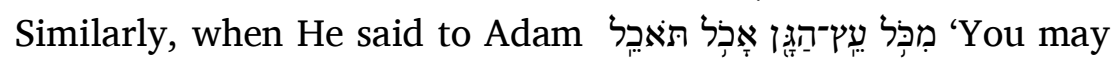
eat of every tree of the garden' (Gen. 2.16), if He had not pronounced qames under the 'alef and holem over the kaf, it would not have been known that this is an infinitive. This is because the meaning of the letters in a case such as אכל changes with patah, resulting in the change of vowels into the form אָכז When patah occurs in the place of holem, it becomes a past verb. So with אָכל when shewa occurs in place of qames, it becomes an

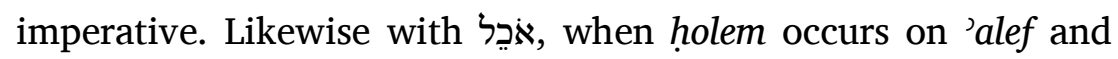


יואצעהא אללה תע לאן אלמואצעה לא בד להא מן אלאשארה אלי אלשי אלמתואצע עליה ואלאשארה לא תכון אלא בגארחה והו תע יתעאלי ען אן יכון בדי גארחה (L5:3r) ואן כאן קד קאל בעצהם אנה יגוז אן יכלק גארחה [יואצע] בהא כמא יגוז אן יכלק אלה ללכלאם ויתכלם בהא לכן עלי אלקול אלאול יכון עלמהם אללגה עלי וגה והו אן יכון קאל ללמלאיכה יהי אור פחדת פי אלתאני מן קולה ואצטרהם אלי אן אור אסם אלשי אלחאדת מן בעד אלקול פעלמוה ומא כאן סואה גרי מגראה ויכון קד אידהם באלקבול ואלחפט מן אול מרה

II.L.2.2.2. פלמא קאל יהי אור לם יכון בד מן חרכה אלשוא מנטוק בהא תחת אליוד ואלחרק תחת אלהא (L5:3v) חתי יכון יהי מסתקבלא וכדלך למא קאל לאדם מכל עץ הגן אכל תאכל לולא מא אתי בחרכה אלקמץ תחת אלאלף וחרכה אלחלם פוק אלכאף למא

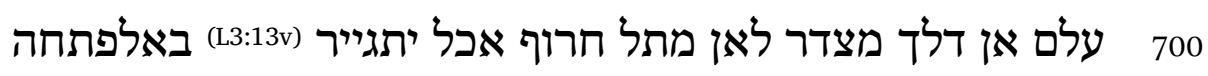

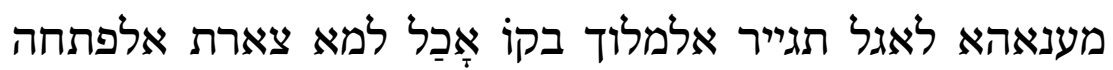
עוץ אלחלם צאר פעלא מאציא וכדלך אָכל למא צאר עוץ אלקמץ שוא צארת אמרא כדלך אָכל למא צאר עלי אלאלף 
sere under the kaf, it becomes a participle. The changes in meaning of these three letters that you see, without themselves changing, are all due to the change of vowels, so without them none of what has been mentioned (with regard to changes of meaning) could have come about and no speech would have

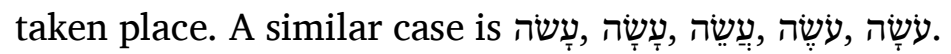

\section{II.L.2.2.3.}

So it is clear to you that the vowels are not innovations but rather the fourth of the obligatory requirements, in accordance with what has been discussed previously in the first discourse. A single letter may exist without a vowel. When a speaker wants to speak, he adds to the single letter another letter, and further letters, but he is in no circumstances able to add a second letter when the first letter is deprived of a vowel. A letter is an element (of speech), but communication between people can only be achieved by combining a letter with a vowel. A letter can stand without a (subsequent) vowel but a vowel can only stand with (a preceding) letter.

\section{II.L.2.3. Section concerning what Corresponds to (Arabic) Inflectional Vowels}

\section{II.L.2.3.1.}

In this regard it has been said that vowels are a basic component of speech and every language requires certain vowels so that speakers can make their intentions understood to one another.

\section{II.L.2.3.2. Section}

The Arabs have three inflectional vowels in their language. These are 'raising' ( $r a f$ ), i.e. the vowel damma, which is written above; 'holding level' (naşb), i.e. the vowel fatha, which is written above; and 'lowering' (khafd), i.e. the vowel kasra, which is written below. They also have vowelless inflection 


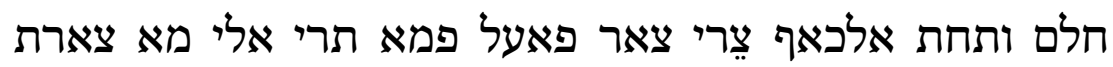

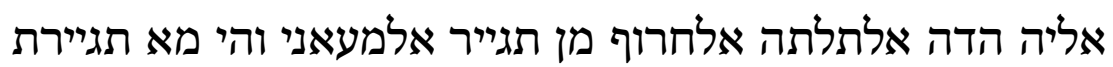

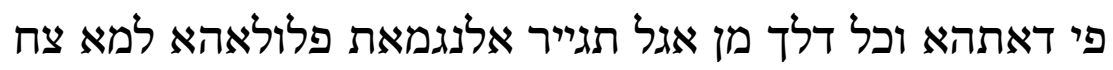

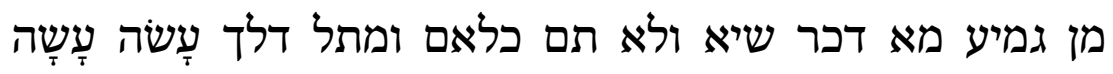

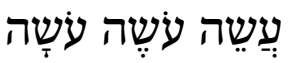

II.L.2.2.3.

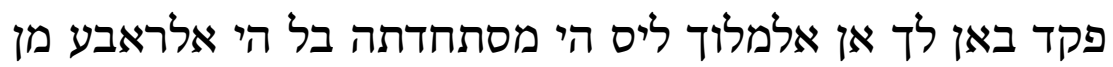
710 אלאפתקאראת עלי מא מצא אלכלאם פי אלמקאלה אלאולי

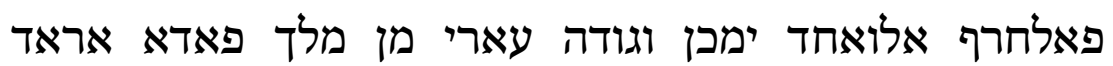
אלמתכלם אן יתכלם זאד עלי אלחרף אלואחד חרף אכר ומא זאד גיר אנה לא ימכן אן יזיד חרפא תאניא ואלאול עארי מן

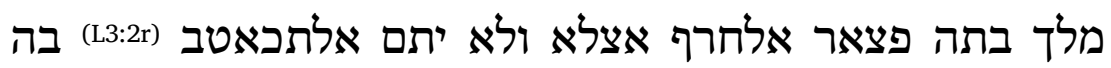

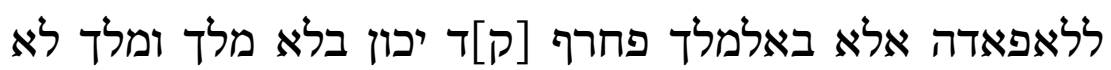
יכון אלא בחרף לאפדה II.L.2.3. פצל [פי] מא גרי מגרי אלאעראב

II.L.2.3.1.

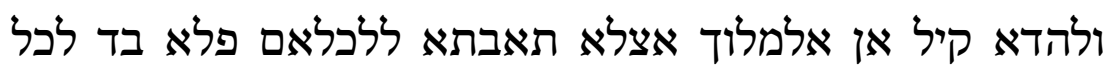

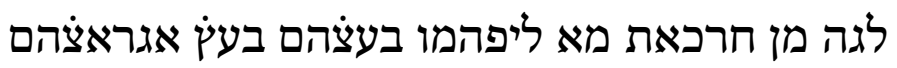

II.L.2.3.2. 720 ללערב פי לגתהם מן אלאעראב תלתה והי אלרפע והו אלצמה מן פוק ואלנצב והו אלפתחה מן פוק ואלכפץ והי אלכסרה מן אספל ולהם אלגזם אלדי יגזמו בה אלחרף אעני יסכנהו והי 
(jazm), in which they cut short a letter, I mean they make it quiescent (without a vowel). This is a circle (sign) written over the letter that is made quiescent. 'Raising' ( $r a f$ ) is a form such as Zayd-u, 'holding level' (nașb) is Zayd-a and 'lowering' (khafḍ) is Zayd-i. They have given the agent raf' inflection due to its agency. They have given the patient nașb inflection due to the occurrence of the action upon it. They have made the affixed particles bi-, $k a$ - and li- govern khafd inflection and they say $d \bar{a} r$ li-Zayd-in 'a house of Zayd', marartu bi-Zayd-in 'I passed by Zayd', Zayd-u ka-Bakr-in 'Zayd is like Bakr', and the same applies also to other particles that govern khafd inflection other than these three affixes, i.e. min, 'alā, 'an, 'ilā, fawqa, 'asfala, tahta, quddāma, and other khafḍ-governing particles. I have mentioned this to show that the Hebrew language has vowels corresponding to these inflectional vowels that are greater in number than those of the Arabic language. In this respect Hebrew exhibits its superiority over Arabic, as it does in other features that are not connected with the topic I have described.

\section{II.L.2.4. Section on the Correspondence (of Hebrew Vowels) to Arabic Inflectional Vowels}

(What corresponds to) Arabic inflectional vowels ('i $r a \bar{b} b$ ) in the Hebrew language consists of three categories: 'raising' ( $r a f$ ), 'holding level' (naṣb) and 'lowering' (khaf̣̂). (What corresponds to Arabic) vowelless inflection (jazm) in Hebrew falls into two categories, one like the vowellessness of the Arabic language and the other is not found in it (i.e. in Arabic). For this reason I have said that the vowels of our language are greater in number than the inflectional vowels of Arabic. The last category (i.e. mobile shewa) is divided into three types. The first of these types corresponds to the three types of Arabic inflectional vowels. The second type corresponds to the 'holding level' (nasb) only. The third type corresponds to the 'lowering' (khafd) only. What 
דאירה עלי אלחרף אלמגזום פאלרפע נחו זיד ואלנצב זידאא ואלכפץ זיד פגעלו אלפאעל מרפוע בפעלה וגעלו אלמפעול מנצובא בוקוע אלפעל עליה וגעלו אלבא ואלכאף ואללאם אלזואיד תכפץ פיקולון דאר לזיד, ומררת בזיד, וזיד כבפּר, מע מא להם מן חרוף אלכפץं גיר אלג זואיד והי מן ועלי וען ואלי ופוק ואספל ותחת וקדאם אלי גיר דלך מן אלחרוף אלכאפצה ואנמא אורדת דלך לאורי אן אללגה אלעבראניה להא ממא יגרי מגרי אלאעראב אכתר ממא ללגה אלערביה פתטהר פצילתהא פי הדא אלוגה מע מא להא עליהא סוא דלך ממא ליס יתעלק בה אלכלאם פי מא קצדתה פצל [פי] מא יגרי מגרי אלאעראב II.2:2v) II.2.4. אלאעראב פי אללגה אלעבראניה תלת רפע ונצב וכפץ ואלגזם פי אלעבראני עלי קסמין אלואחד מתל גזם אללגה אלערביה ואלאכר ליס הו להא פלהדא קלת אן חרכאת לגתנא אכתר מן אעראבהא והדא אלקסם אלאכיר ינקסם עלי ג אקסאם אלקסם אלאול מן הדה ינוב ען ذ אקסאם אלאעראב ואלקסם אלذ ינוב ען אלנצב פקט ואלקסם אלג ינוב ען אלכפץ פקט אלרפע פי 
corresponds in Hebrew to (the Arabic inflectional vowel) 'raising' (raf) are two vowels, namely is and אוז. Three vowels correspond to (the Arabic inflectional vowel) 'holding level'

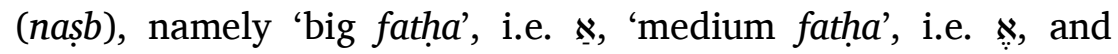
'small fatha', i.e. N̦. Two vowels correspond to (the Arabic inflectional vowel) 'lowering' (khafḍ), namely אִ ạ. The vowelless inflection (jazm) is the quiescent shewa. This is the vowellessness of Arabic. The other jazm is the mobile shewa. This, as I have mentioned, is divided into three types. The shewa requires special discussion and this will come in its appropriate place, with the help of God.

\section{II.L.2.5. Section (on Raf)}

Take note that one category of 'raising' (raf) in the Hebrew language is used in the active participle in certain conjugations,

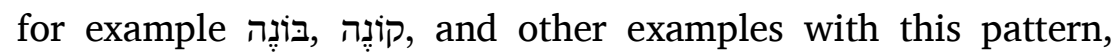

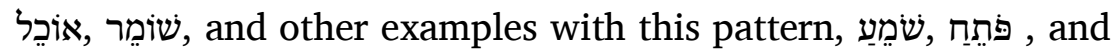
other examples with this pattern. To these should be added forms that are used for the imperative and the past such as 'be burnt', שוֹר 'was burnt', and other examples of this pattern; those that are used for the imperative in the conjugaton סב ' סו 'be gracious'; those that are used for the past in the conjugation נשירו, such as נוֹשֵׁע 'be known', saved'; those that are used for unconjugated nouns designating bodies

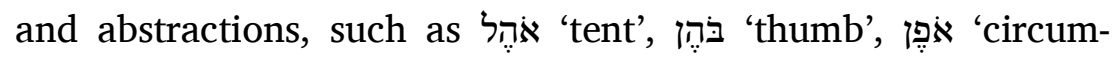
stance', אוֹעָר 'store', and similar cases, and the abstractions

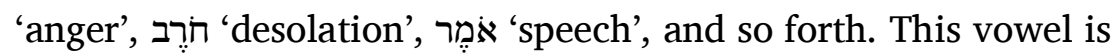
not found in (forms expressing) a patient. This category (of raf) is used for agents, just as the Arabs use [their] raf c for agents. The Hebrews use it for forms other than those designating agents by extension, just as the Arabs use their raf ${ }^{c}$ for forms other than those designating agents by extension, such as 
לגה אלעבראני דכל תחתה נגמתאן והמא או ואו ואלנצב ידכל

תחתה ג̇ נגמאת אלפתחה אלכברי והי אַ ואלפתחה אלוסטי והי ֶֶ ואלפתחה אלצגרי והי אָ ואלכפץ ידכל תחתה נגמתאן והמא אֵי אִי ואלגזם הו אלשוָא אלסאכן והו אלגזם אלדי ללערבי ואלגזם אלאכר הו אלשוָא אלמתחרך והו אלדי דכרת אנה ינקסם ג אקסאם וללשוא כלאם מפיד פיגי פי מוצעה בעון אללה

פצ' I.L.2.5. אעלם אן אלקסם אלואחד מן אלרפע פי אללגה אלעבראניה

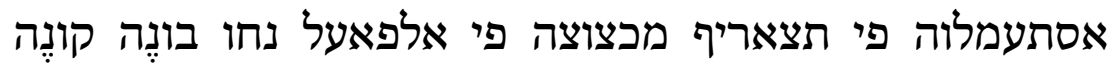

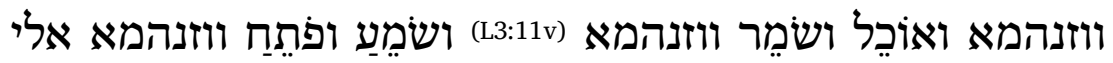
גיר דלך ממא קד אסתעמל פי אלאמר ואלעבר מתל שוֹרךף ושיר שוֹרַף ווזנהמא ואסתעמל פי אלאמר מן תצריף כוֹנֶן נחו סב חן ואסתעמל פי אלעבר מן תצריף שירו נחו נוֹדַע נוֹשַע ואסתעמל פי אלאסמא אלגיר מתצרפה פי אלאגסאם ואלאעראץ כקוֹ פי

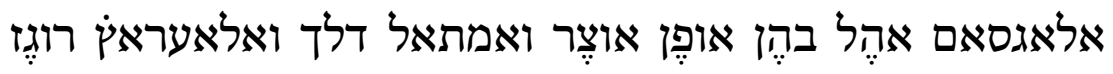

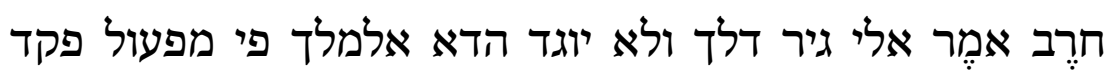
צאר הדא אלקסם אלואחד יסתעמל פי אלפאעלין כמא אסתעמלו אלערב רפע[הם פ]י אלפאעלין ואסתעמלו

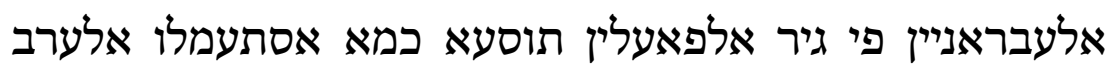
רפעהם פי ג[יר] אלפאעלין תוסעא מן נחו אלאבתדא 
topicalization, interrogative constructions, and so forth. Nobody can object to my statement that this category of $\mathrm{raf}^{\prime}$ is not used

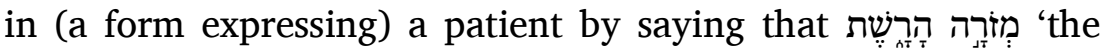
net is spread' (Prov. 1.17) is a patient and that it has been made a patient by raf', i.e. אis This is because my statement refers only to cases where this type of $\mathrm{raf}^{`}$ occurs at the beginning of a word with the first letter but the mem in מִזָרָה has been placed before the raf ${ }^{c}$, and it is for this reason that I have stated that this category of $\mathrm{raf}^{\mathrm{c}}$ is not found in a patient.

\section{II.L.2.6. Section on the Second Raf}

As for $\mathrm{w}$, the Hebrews use this in the imperative of (conjugations

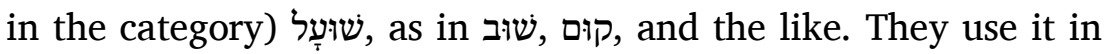
a verb whose agent is not named (i.e. a passive verb), for

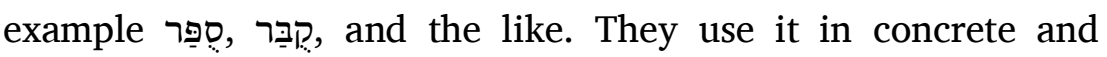
abstract nouns and in the names of people. An example of a

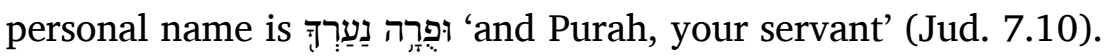

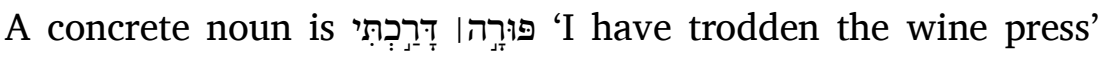

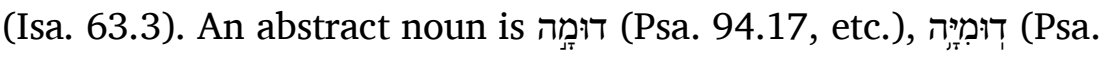
22.3 , etc.) 'silence'. To these can be added further examples.

\section{II.L.2.7. Section on Naṣb}

\section{II.L.2.7.1.}

The small naşb, which is qames, like nasb in the language of the Arabs, is used in (forms expressing) the patient, for example

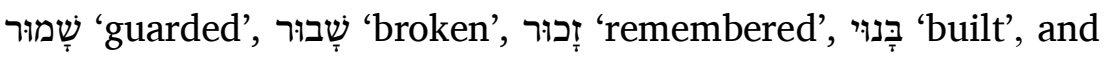
the like. It is used in the 'absolute patient', i.e the infinitive, as

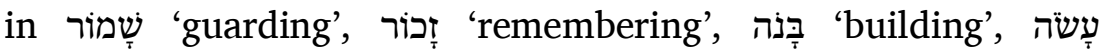
'doing', and the like. It is used in past verbs, such as שָָׁ 'he built', בָּנָה 'he built', and the like. It is used in the form that קָ and words with this pattern. 
760

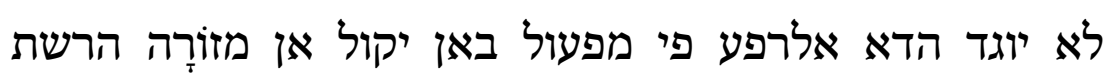
מפעולה ובאלרפע צארת מפעולה והו או לאן אנמא כלאמי פי מא כאן הדא אלרפע פי אול לפטה מע אלחרף אלאול ואלמאם פי מזורָה קד תקדם [אל]רפ[ע פלדל]ד קלת אנה לא יוגד פי

$$
\text { מפעול מן הד]א אלקס]ם }
$$

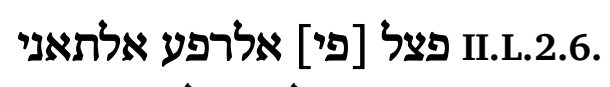
(L3:11r) קום ואמתאל דלך ואסתעמלוה פי אלפעל אלדי לם יסם פאעלה מתל סְפַר קְבַר ונחוהמא ואסתעמלוה פי אלאסמא אלגאמדה ואלאעראץ ואסמא אלנאס פאסם אנסאן מתל ופוּרָה נערך ואלגמאד פוּרָה דרכתי ואלערץ דוּמָה דומיה אלי גיר דלך פצל פי אלנצב II.L.2.7. II.L.2.7.1. אלנצב אלצגיר והו אלקאמצה תגרי מגרי אלנצב פי לגה אלערב יסתעמל פי אלמפעול כל שָמוֹר שָבוּר זָכוּר בָנוּי [ואמ]תאלה

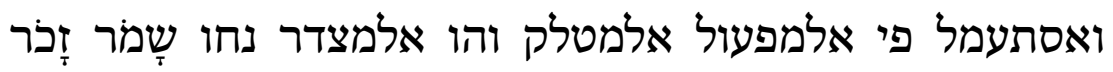
בָנה עָשוֹה ואמתאל דלך יסתעמל פי אלאפעאל אלמאציה נחו

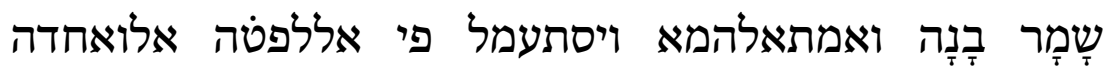
ללעבר ולאסם אלפאעל מתל שָם קָם ואוזאנהמא 


\section{II.L.2.7.2.}

The 'big nașb' is used in imperatives from (conjugations in the

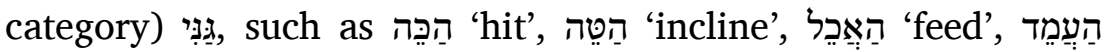
'cause to stand', and the like. It is used in 'transposed

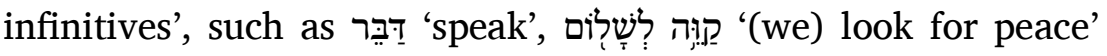
(Jer. 8.15, etc.), and other forms expressed by this category of naṣb.

\section{II.L.2.7.3.}

The third (category of) naşb, i.e. segol, is used in imperative

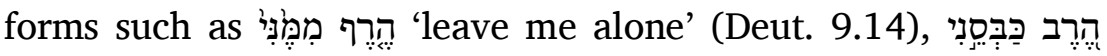
'wash me thoroughly' (Psa. 51.4). They use it in past forms such

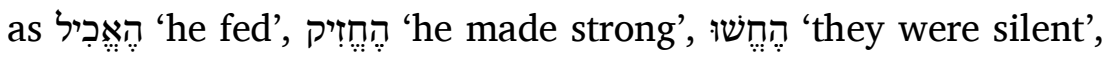
and so forth.

\section{II.L.2.8. Section on Khafd}

\section{II.L.2.8.1.}

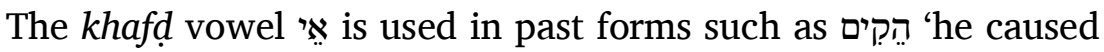
to rise', העיד 'he bore witness'. It is used in a noun of agent (active participle) such as מֵקִים 'causing to rise', מֵעִיד 'bearing witness'. It is used in imperative forms substituting for the other category of khafd (i.e. hireq) when it is followed by one of the

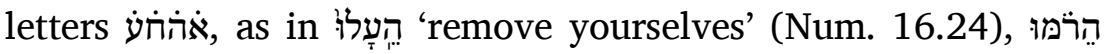
מִתזוֹּ 'remove yourselves from the midst' (Num. 17.10), and the like.

\section{II.L.2.8.2.}

The second category of khafd, i.e. is is used in the past of all

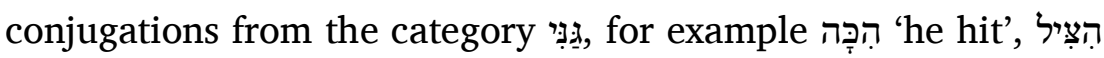

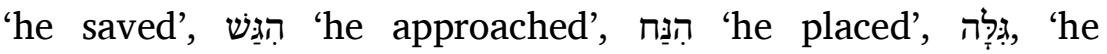

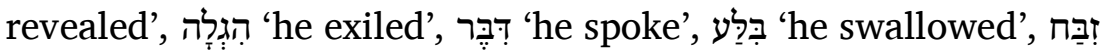


II.L.2.7.2.

אלנצב אלכביר יסתעמלוה פי אלאואמר מן גַנְיִי נחו הכֵה הטֵה 780 נחו דבֵר קוּה לשלום אלי גיר דלך ממא יפידה הדא אלנצב

II.L.2.7.3. אלנצב אלתאלת והו אלסגול אסתעמלוה (L5:19r) פי אלאמר נחו

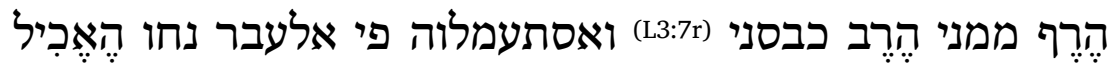

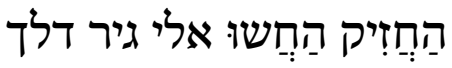
פצ' II.L.2.8. 785 II.L.2.8.1. אלמלך אלדי ללכפּץ אֵי אסתעמלוה פי אלעבר נחו הַקְים הַעִיד ואסתעמלוה פי אסם אלפאעל נחו מֵקִים מֵעִיד ואסתעמלוה פי אלאמר נאיבא ען אלכפץ אלאכר אדא כאן בעדה חרף מן חרוף אָהזֹע נחו הֵעָלו הֵרמו מתוך אלי גיר דלך

790

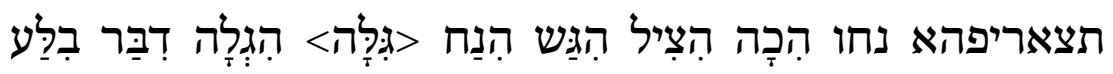
L3 786 אי] אָ L5:19r 


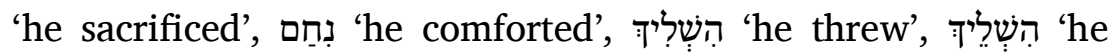

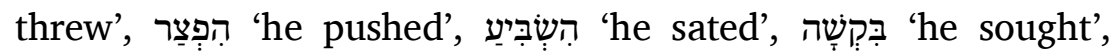

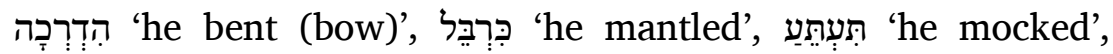

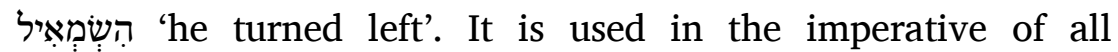

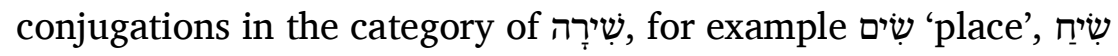

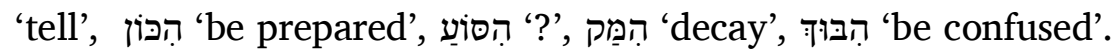
It is used in the imperative, the past and the active participle of

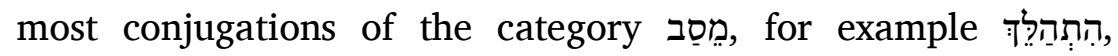

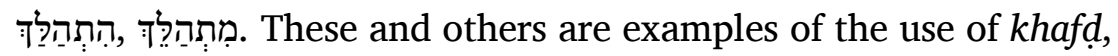
naşb and rafc in the Hebrew language.

\section{II.L.2.9. Section (Preliminary Remarks on the Shewa)}

(What corresponds to Arabic) vowellessness (jazm) in the Hebrew language is the quiescent shewa. This is because the shewa falls into two categories, quiescent and mobile. The quiescent shewa is what deprives a letter of a vowel so that it is not mobile. The mobile shewa is additional to the (inventory of) vowels of the Arabic language, (the treatment of which) has various subsections.

\section{II.L.2.10. Section concerning the Shewa}

\section{II.L.2.10.1.}

The shewa is divided into two categories, quiescent and mobile. There is no third category. The quiescent shewa has features by which it is distinguished from the mobile shewa. The mobile shewa has two features by which it is distinguished from the quiescent shewa.

\section{II.L.2.10.2.}

A feature of the quiescent shewa is that it makes a letter under which it occurs quiescent and makes it part of the preceding 


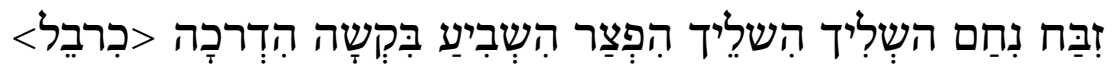

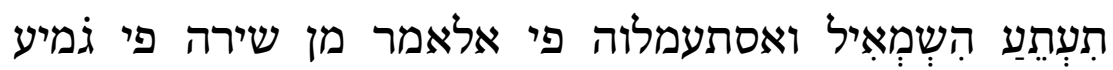
תצאריפהא נחו שִים ושִיח וְִכוֹן והסוע והמק והבוך ואסתעמלוה פי אלאמר ואלעבר ואלפאעל מן עלאמה מֵסַב פי אכתר תצאריפהא נחו התהלֶד התהלֵך מתהלֶך אלי גיר דלך ממא אסתעמל אלכפץ ואלנצב ואלרפע פי לגה אלעבראניה פצל (L5:20r) II.L.2.9. אלגזם פי לגה אלעבראני הו אלשוא אלסאכן לאן אלשוא עלי 800 יתחרך ואלמתחרך הו אלזאיד ען אנחא אללגה אלערביה ולה פנון עדה - - - - - - - - n

פצל פי אלשוא II.L.2.10.

II.L.2.10.1. אלשוא ינקסם קסמין סאכן ומתחרך ולא קסם תאלת להמא 805 פללסאכן עלאמאת יתמייז בהא מן אלמתחרך וללמתחרך עלאמתין יתמיז בהא מן (L5:20v) אלסאכן

II.L.2.10.2. מן עלאמה אלסאכן אנה יסכן אלחרף אלדי הוא תחתה ויגעלה 


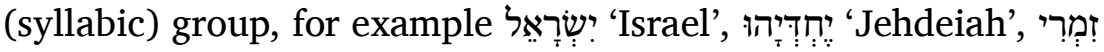

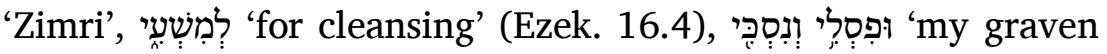
image and my molten image' (Isa. 48.5). So the letter under which the (quiescent) shewa occurs becomes quiescent. Whatever letter it occurs under is not mobile at all and it (the quiescent shewa) cuts it off from what is after it and conjoins it to what is before it.

\section{II.L.2.10.3.}

Another of it features is that it divides a word into (units) that have the status of words. This is because every letter at the end of a word is quiescent when it is deprived of an accompanying vowel and this letter that is deprived of a vowel is the stopping point of the word and its place of division, as in which the tav is the stopping point of the word, and רis, in which the resh is the stopping point of the word, and so forth. A quiescent shewa in the middle of a word has the same status, for it is in a sense a stopping point on account of its quiescence, for

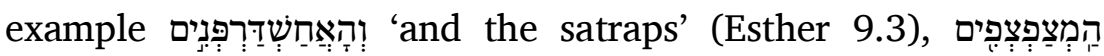
'those who chirp' (Isa. 8.19). Each of these two expressions has the status of three words on account of the quiescent shewa. If it were absent, this division would not be admissible.

\section{II.L.2.10.4.}

Another of its features is that it indicates the feminine gender in many cases, for example, רחסֶצְת (you (fs.) washed and you painted (fs.) (your eyes)' (Ezek. 23.40), and similar cases. Forms

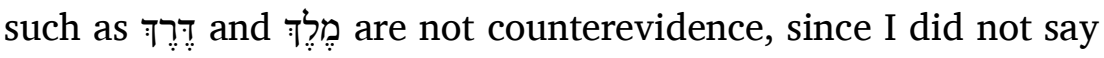
that it occurred at the end of a word only to express the feminine gender, but that it indicates feminine gender in many cases. 


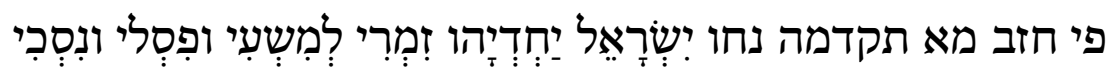
פצאר אלחרף אלדי תחתה אלשוא סאכנא לא יתחרך בתה מהמא הוא תחתה ופצלה ממא בעדה ואצאפה אלי מא קבלה

II.L.2.10.3. ומן עלאמאתה איצא אנה יקסם אללפטה מתאבה כלם לאן כל חרף פי אכר כלמה הו סאכן אדא ערי מן מלך יכון מעה פיכון דלך אלחרף אלעארי מן (L4:4r) מלך הו מחט אלכלמה ומקטעהא

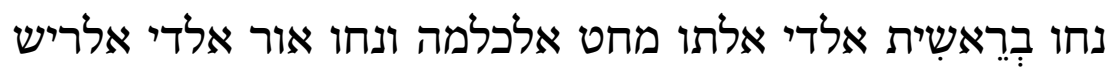
מחט אלכלמה אלי גיר דלך פאלשוא אלסאכן פי וסט אלכלמה יגרי הדא אלמגרי לאנה קד צאר מחט עלי וגה לסכונה מתל והאחשדרפנים המצפצפים צארת כל לפטה מן האתין אללפטתין במתאבה תלת כלם לאגל אלשוא אלסאכן ולו אנעדם לם תצח אלקסמה פיהא

II.L.2.10.4. ומן עלאמאתה איצא אנה ינבה עלי אלתאנית פי כתיר מן (L4:4v)

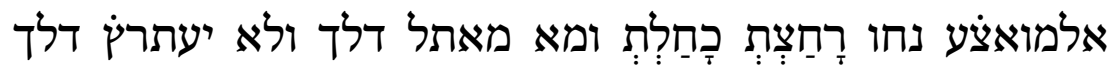

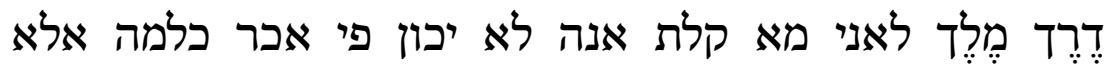
ללתאנית ואנמא קלת אנה ינבה עלי אלתאנית פי כתיר מן

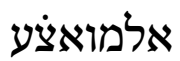




\section{II.L.2.11. Section (on the Nature of Mobile Shewa)}

\section{II.L.2.11.1.}

A feature of mobile shewa is that when it occurs under a letter, the letter is not in any way static or at rest. If a speaker wished to make it quiescent, he would never speak, just as if a speaker wanted to always make a quiescent shewa mobile, ....

\section{GAP}

\section{II.L.2.11.2.}

Another of its features is that it does not make the letter following it quiescent but rather only makes the third letter after it quiescent. This statement is valid since it (the mobile shewa) itself is not removed from under its letter but rather its letter is made mobile and the letter after it is made light (i.e. rafe). Quiescence may occur in the third letter or one greater (in number) than that. Examples of the occurrence of quiescence on

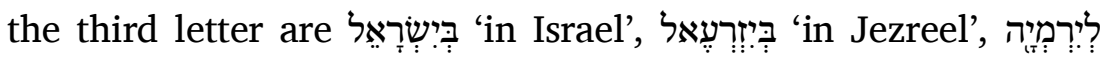
'to Jeremiah' (Neh. 12.12, etc.). Examples (of quiescence) in a

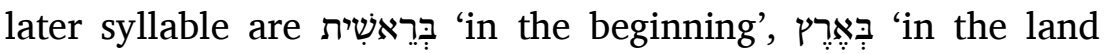
(of)', בְּחָרֶר 'with a sword', and similar cases.

\section{II.L.2.11.3.}

And if somebody were to say 'What are the full facts concerning the two of them, I mean the quiescent and the mobile shewa?', the response would be as follows. As for the quiescent shewa, I do not know any more of its distinctive features than those that I have already mentioned. With regard to the mobile shewa, it must be treated in various subsections. All the following subsections, therefore, concern the mobile shewa rather than 
פצל II.L.2.11.

825

II.L.2.11.1.

מן עלאמה אלמתחרך אנה אדא כאן תחת חרף לא יסתקר דלך

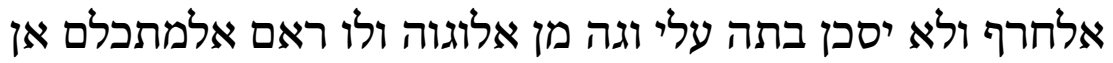

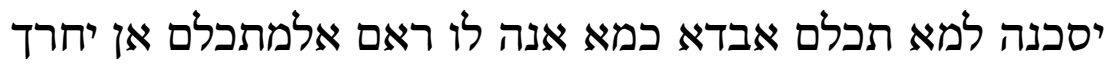
אלסאכן דאימא

\section{GAP}

II.L.2.11.2.

(L5:4r) ומן עלאמאתה איצא אנה מא יסכן עלי אלחרף אלתאני מנה בל לא יסכן אלא עלי אלחרף אלתאלת הדא אלקול הו תגוז לאנה הו בעינה לא יברח מן תחת חרפה ואנמא יתחרך חרפה ויכף אלחרף אלדי בעדה פקד יקע אלסכון פי אלתאלת וקד יקע פי מא זאד ען דלך פתקול פימא וקע אלסכון פי

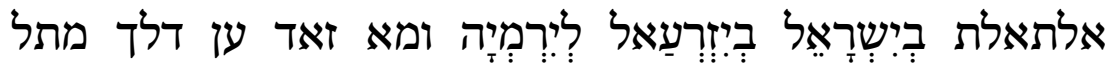

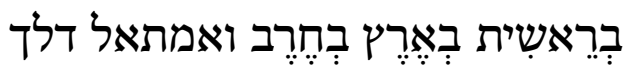

II.L.2.11.3. פאן (L5:4v) קאל פמא מחצה אלפאידה בהמא אעני אלסאכן ואלמתחרך קיל לה אמא אלסאכן פמא ערפת לה מן אלחט אלא מא דכרתה מן עלאמאתה ואמא אלמתחרך פהו אלמפנן באלפנון פגמיע מא בעד מן אלפנון פהי ללמתחרך דון אלסאכן 
the quiescent shewa. It is not necessary to mention the corresponding quiescent shewa in each place, since it is sufficient to say that the quiescent shewa does not have any more features than those that have been mentioned. I shall present below the various subsections concerning the mobile shewa.

\section{II.L.2.12. Chapter concerning the Mobile Shewa and what is Related to this}

Take note that the inventory (of letters) consists of twenty-two basic letters, in addition to which there are the 'straight' letters, the letters with rafe and the letters 'between two grades', as has been stated previously. The discussion here relates only to basic features and not to secondary features.

\section{II.L.2.12.1. The First Subsection}

\section{II.L.2.12.1.1.}

This is its influence by the four letters אהंזע. When these four letters are preceded by a letter that is not one of them and under this letter there is shewa, the shewa is pronounced as a shortened vowel like the vowel that is under one of the four letters. Now, if it is appropriate for $g a^{c} y a$ to occur on it, it is pronounced equal to the vowel (following it). For example, וְאִּכָכָכָה 'and if thus' (Num. 11.15), in which shewa is under vav and the vav is pronounced with hireq like that which is under the 'alef, but shortened since it it does not have ga'ya. Surely you see that when it is appropriate for it to have gaya, it is pronounced with the (vowel) pronounced on the letter equally, without any difference, for example 'and if there remains' (Exod. 29.34). Similar to the preceding examples are 
פלא חאגה אלי דכר סאכן אלמתחרך פי כל מוצע אד קד גנית בקולי אן מא ללסאכן פאידה גיר מא דכר מן עלאמאתה פאדכר מא יתגה מן פנון אלמתחרך

II.L.2.12.

845 אעלם אן אלקבאלה אתנין עשרין חרפא אצולא מא סוי אלפשוטות ואלחרוף אלמרפיה ואלחרוף אלמנזלה בין מנזלתין

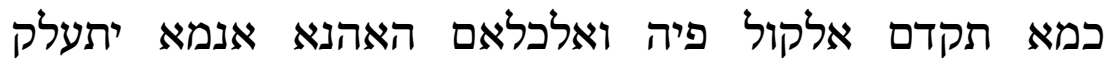
באלאצול דון אלפרוע

$$
\text { II.L.2.12.1. }
$$

II.L.2.12.1.1. אלפן אלאול הוא מא יחצל לה מן אלתאתיר פי ארבע חרוף 850 סואהא תחתה שוא כרג דלך אלשוא בכרוג (L5:5v) דלך אלמלך אלדי תחת אלארבעה חרוף מכפפא אלאן אן יחסן מעה דכול אלגעיה כרג בכרוֹ אלמלך סוא נחו וְאִם כָכָה אלשוא תחת אלואו כרג אלואו בחרק מתל מא תחת אלאלף מכפפא למא לם 855 תכון מעה אלגעיה אלי תרי אן למא חסן מעה דכול אלגעיה כרג בכרוג אלחרף סוא מן גיר פרק כקו וְאִם יְוּתֵּר ומתל אלדי תקדם 


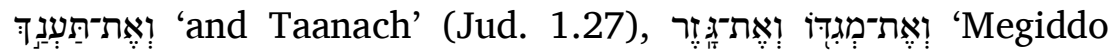
and Gezer' (1 Kings 9.15), in which the shewa is pronounced as a shortened segol. When, however, you say וֶָת 'and his sons' (Gen. 9.1, etc.), the shewa is pronounced with a segol of full length on account of the gaya, and so also other cases where shewa is pronounced with the pointing of the 'alef.

\section{II.L.2.12.1.2.}

As for he, a shewa before it is pronounced with the vowel of the he, for example in וזיזָ the shewa is pronounced as a short qames on account of the absence of ga'ya. When ga'ya is appropriate, the shewa is pronounced with the qames of the he with its full

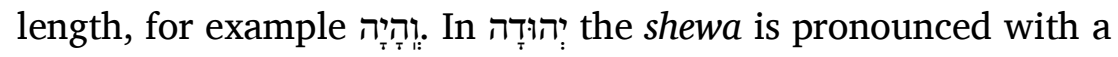
shortened qibbus, due to the absence of gacya, and other cases where shewa is pronounced like the pointing of the he.

\section{II.L.2.12.1.3.}

Het: Examples of shewa before het are רחוֹקָקה־הִיא 'it is far' (Jdg 18.28), 'for (I heard) the voice of a woman in travail'

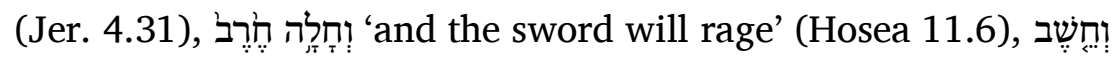

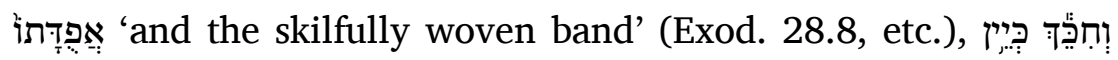
הַטַּ 'and your palate is the best of wine' (Cant. 7.10), and other cases.

\section{II.L.2.12.1.4.}

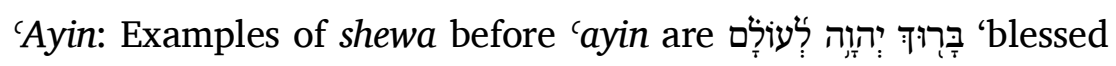
be the Lord for ever' (Psa. 89.53), in which the lamed of לִ is is pronounced with a holem like the 'ayin but shortened. When it is appropriate for it to have ga'ya, there is no difference between

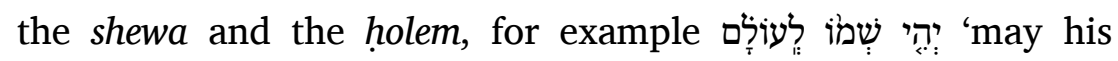


>וְאֶת> תענך וְאֶת מגדו וְאֶת גזר כרג אלשוא בתלת נקט מכפפא ואדא קלת וֶֶֶת בָנָנו כרג אל (L4:1r) שוא בתלת נקט מסתופאה לאגל אלגעיה אלי גיר דלך ממא יכרג אלשוא בנקט 860

II.L.2.12.1.2. אלהא יכרג אלשוא אדא כאן קבלה באלמלך אלדי יתחרך אלהא כקוֹ וְהָיזה כרג אלשוא בקמצה כפיפה לעדם אלגעיה

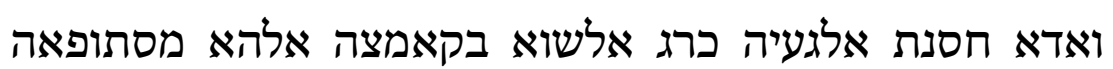

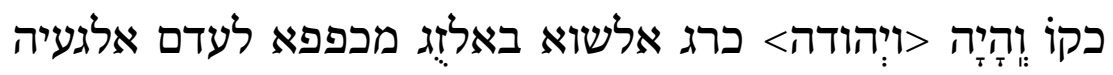
865 אלי גיר דלך ממא [כ]רג אלשוא בנקט אלהא

II.L.2.12.1.3. אלחית אלשוא קבל אלחית כקוֹ רִחוֹקָה היא כי קוּל כ]חולה (L4:1v)

אלעין אלשוא קבל אל אלעין ברוך ייי לְעוֹלָם כרג אללמאד מן לִעוֹלם [ב]חלם מתל אלעין מכפפא ולמא חסן מעה דכול 870 אלגעיה לם יכון בין אלשוא ואלחלם פרק נחו יהי שמו לְעוֹלם 


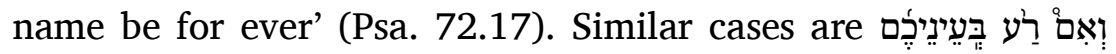

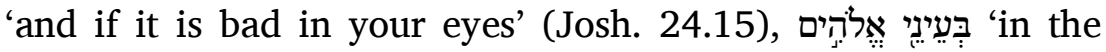

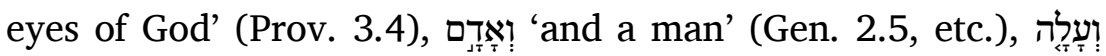

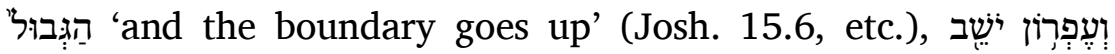

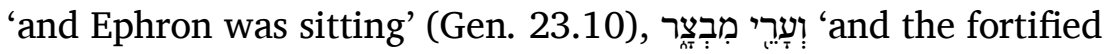
cities' (Josh. 19.35), and other cases.

\section{II.L.2.12.1.5.}

Now this rule applies to shewa with the four letters when shewa is under a letter that is not one of the four.

\section{II.L.2.12.1.6.}

When it is of one of the four, the rule does not apply, for

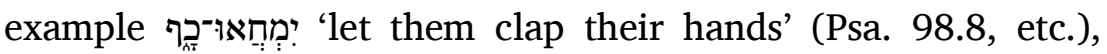

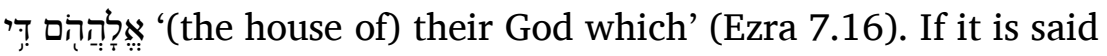
'Why is it that these four letters differ in this way from the other letters when they come before (another of the four letters) and have shewa, and why does the rule not apply to all (letters)?', the response to him would be as follows. Since the letter (i.e. one of the אהזהע letters) that is before the four letters requires a vowel together with shewa (i.e. a vowel represented by a hațef sign), the vowel (of the hatef) is dominant, so the shewa does not have any influence and the het of ימְּח is pronounced with patah

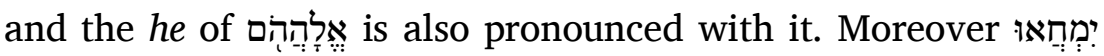
cannot be pronounced with patah and shureq and it is also not possible for it be pronounced with shureq and not patah, for if it were pronounced with shureq, I mean qibbus, there would be no reason for patah to occur. Since these two situations are impossible, it must be pronounced with patah, due to its natural

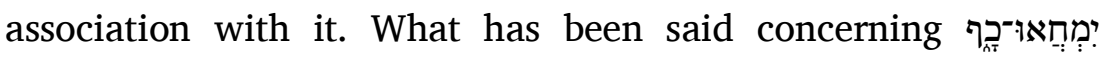
applies equally to אֶלְהָהָּם If somebody says 'Why are the other 


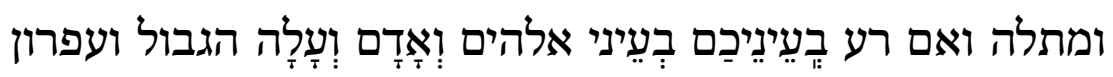

$$
\text { יושב וְעָרֵי מבצר אלי גיר דלך }
$$

II.L.2.12.1.5. אלאן הדא אלשרט לאזם פי אלשוא מע אלארבע חרוף מתי

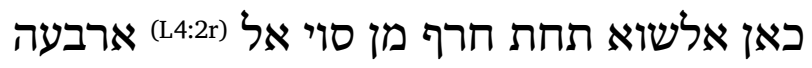

II.L.2.12.1.6. 875 פאמא אן כאן מן אלארבעה בטל הדא אלשרט נחו קוֹ יִמְחְאוּ

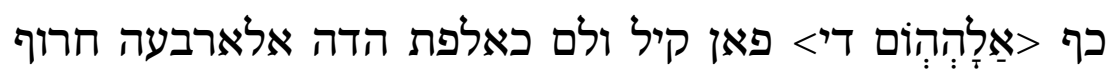
אדא כאנת קבל ותחתהא שוא לסאיר אלחרוף פי מא הדא סבילה ולם לא כאנת אלעלה סאירה פי אלכל קיל לה למא כאן

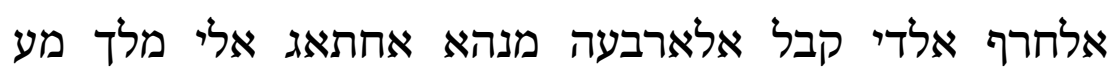
880

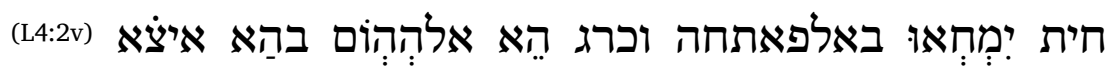
ואסתחאל כרוג ימחאו באלפתחה ואלשרק ואמתנע איצא כרוגה באלשרק מן דון אלפתחה אד לו כרג באלשרק אעני באלזְג לכאן לא פאידה פי מגי אלפתחה ולמא אמתנעא 885 אלהחהֶום כאלכלאם פי ימחאו כף סוא פאן קיל ולם לא כאן חכם 
letters not like these four letters when they are before the aforementioned (four letters), especially when every shewa under a letter must be pronounced as a vowel when ...

\section{GAP}

\section{II.L.2.12.2. (The Second Subsection)}

\section{II.L.2.12.2.1.}

.... because shewa has not changed form but rather is adjacent to it, just as qames is adjacent to patah and other vowels. This is

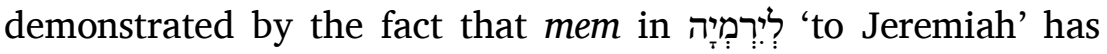
shewa under it and the yod after it has qames under it, but the shewa is not pronounced like qames but rather is pronounced like hireq, unlike the four letters. The shewa of the four letters is restricted by what is before it, but the shewa of yod is not restricted by what is after it. The difference, therefore, is clear between the two subsections.

\section{II.L.2.12.2.2.}

If somebody were to say 'What is the value of us knowing this?', the response to him would be as follows. When shewa comes before yod, in most cases this is an indication of the indefinite. If a vowel were to occur in place of it, this would be an

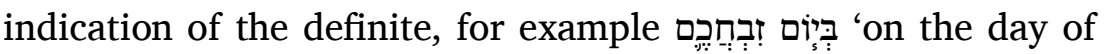

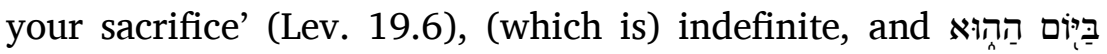

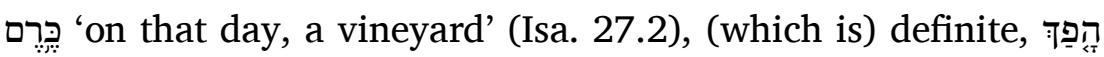

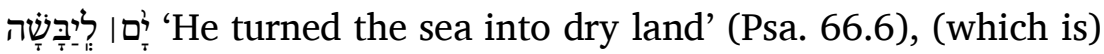

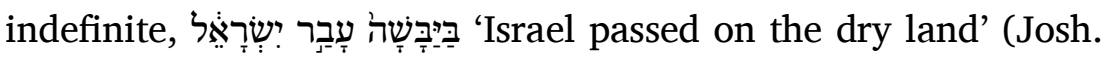
4.22), (which is) definite, and so forth. 
בקיה אלחרוף כחכם הדה אלארבעה אדא כאנת קבל הדה

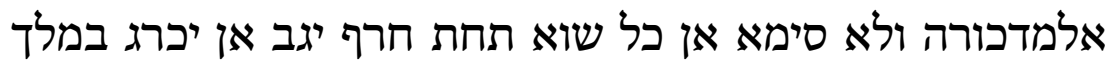
מתי אלמדור

$$
\text { GAP }
$$

II.L.2.12.2.

II.L.2.12.2.1. (L3:3r) 890 ללפאתחה וסואהא מן אלמלוך יביין דלך אן אלמאם מן לירמְיזה תחתה שוא ואליוד בעדה תחתה קמץ ולם יכרג אלשוא באלקאמצה בל כרג בחרק מכאלפא ללארבעה חרוף פשוא אלד חרוף מקצור עלי מא קבלה ושוא אליוד גיר מקצור עלי מא בעדה פאלפרק טאהר בין אלפנין

II.L.2.12.2.2. פאן קאל ומא אלפאידה פי מערפתנא דלך קיל לה אן אלשוא אדא כאן קבל אליוד פי אכתר אלמואצע יכון דלאלה עלי

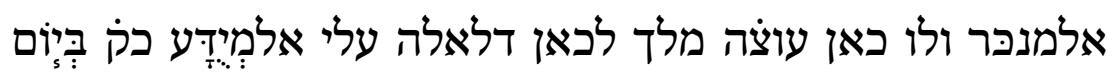

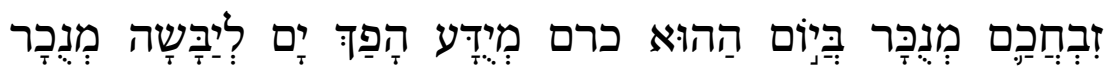
900 


\section{II.L.2.12.3. The Third Subsection}

\section{II.L.2.12.3.1.}

The remainder of the inventory of letters amounts to seventeen letters. If yod (which has been discussed above) is added to them, they come to eighteen letters. Shewa under these eighteen letters is pronounced as a short patah. Examples of cases in which it is not appropriate for ga'ya to occur include

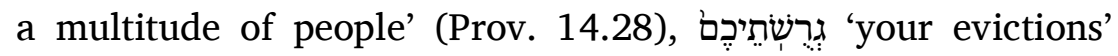

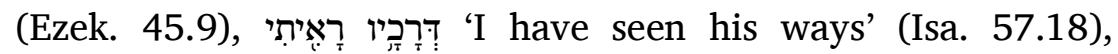

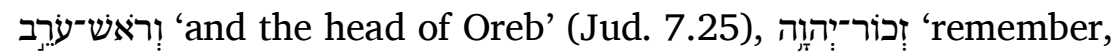

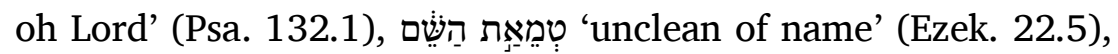

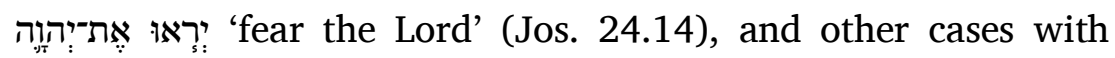
these eighteen letters. If one were to say 'Tell me about the shewa that is pronounced as patah under these eighteen letters. Is it substituting for another (pronunciation), or is it alone the pronunciation that is the rule under the letters to the exclusion of any other, or is this pronunciation together with another the rule under them, or what is the situation concerning this?', the response to him would be as follows. These letters are pronounced as patah. It is a feature of this patah that it is only pronounced short. Shewa is the only way to represent this shortness. Since according to their principles shewa is not combined with a vowel under these eighteen letters, they marked the shewa alone. It was not possible for them to mark the patah by itself, since it would have been pronounced as a full vowel.

\section{II.L.2.12.3.2.}

If one were to say 'According to this statement, when a shewa occurs under these eighteen letters it is only pronounced as short patah, but we seen a contradiction of this in cases such as 'As you rejoiced over the inheritance of 


\section{II.L.2.12.3.}

II.L.2.12.3.1. אלבאקי מן חרוף אלקבאלה יז חרף ותעוד אליהא אליוד תציר יंח חרפא [פה]דא יंח חרפא יכרג אלשוא תחתהא בפאתחה [כפיפה] ומא לא יחסן מעהא דכול געיה כק בְרָב עָם

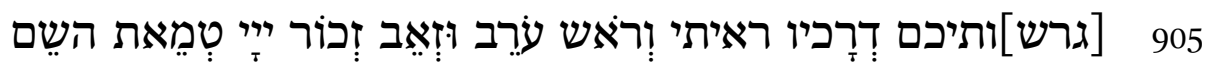

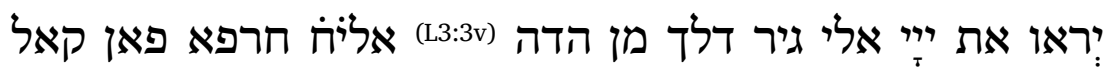
כברני ען אלשוא אלדי יכרג בפאתחה תחת הדה אלחרוף אליז הו נאיב ען גירה אם הו וחדה באלואגב תחת הדה אלחרוף דון גירה אם הו וגירה באלואגב תחתהא אם כיף אלחאל פי דלך 910 קיל לה אן הדה אלחרוף נטקהא אלפאתחה ומן חכם הדה אלפאתחה אלמדכורה לא תכון אלא כפיפה ולא וגה לכפתהא גיר אלשוא ולמא לם יכון אלשוא פי אצולהם יגתמע מע מלך תחת הדה אליח חרפא געלו אלשוא פקט ולם ימכן אן יגעלו אלפאתחה (L4:5r) וחדהא לאנהא תגי מסתופאה

II.L.2.12.3.2. 915 תחתהא שוא לא יכרג אלא בפאתחה כפיפה ונחן נרי כלאף

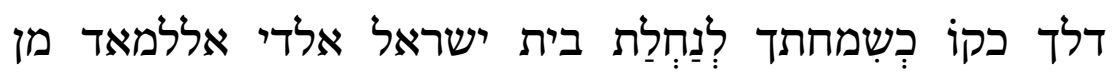


the house of Israel' (Ezek. 35.15), in which the lamed of לִנְּ is is 'heavy', the response to him would be that what makes the lamed heavy is the gaya, for this is the only thing that can change the form of the vocalic pronunciation of the shewa. ${ }^{12}$ If he says '(Why) have they not marked a patah where the ga'ya occurs to express heaviness and a shewa where there is shortness?', the response to him would be as follows. It is not permissible to mark a patah where (the shewa is pronounced with) heaviness, because the rule regarding the marking of shewa and patah on these eighteen letters is that the patah alone does not indicate shewa but shewa alone indicates patah. Furthermore if they marked patah where there is heaviness, that would make it unclear as to whether the following letter had dagesh or not, since one of the features of patah is that in many places it is followed by dagesh to express definiteness, for

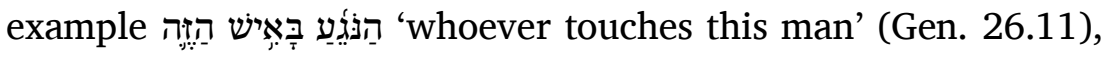

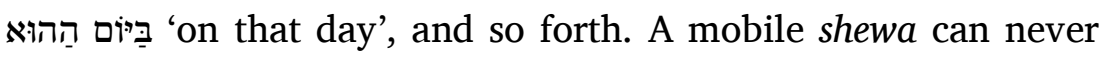
be followed by dagesh in the reading of Scripture, except in שִּנתים and שֶתי In the discussion concerning these below, however, I shall explain that the shewa in these two words is quiescent and not mobile.

\section{II.L.2.12.3.3.}

Furthermore, gacya is not obligatory under a letter as a vowel and shewa are obligatory, because ga ya is only an exhalation of air in speech, and its elision is possible. The reader chooses in his reading (whether to pronounce it or not). There are some places, however, in which the speaker does not have a choice,

\footnotetext{
${ }^{12}$ The extant model manuscripts L, A and C do not have ga'ya on the

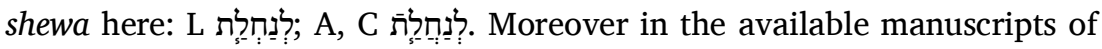
Hidāyat al-Qāri' a ga'ya sign is not marked.
} 
לנחלת תקיל קיל לה אן אלדי תקל ללמאד אלגעיה אד ליס תם שי יגייר חכם תחריך אלשוא סואהא פאן קאל והלא געלו מוצע 920 אלגעיה אלתי תגי ללתתקיל פאתחה ומוצע אלתכפיף שוא קיל לה לא (L4:5v) יגוז אן יכון מוצע אלתתקיל פאתחה לאן אלואגב ללחרף מן הדה אליח אלשוא ואלפאתחה פאלפאתחה וחדהא לא תדל עלי אלשוא ואלשוא וחדה ידל עלי אלפאתחה ואיצא פאן לו געלו אלפאתחה מוצע אלתתקיל לאשכל דלך פי אן אלחרף אלתאני מנה מדגוש או גיר מדגוש לאן מן בעץ אחכאם אלפאתחה פי כתיר מן אלמואצע אן יגי בעדהא אלדגש

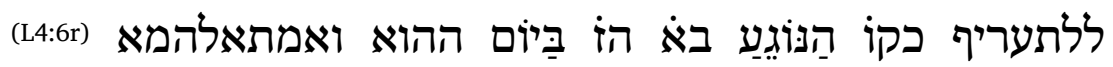
ואלשוא אלמתחרך לא יכון בעדה דגש אבדא פי אלמקרא אלא שְתים ושְתי ועלי מא יגי אלכלאם עליהמא פי מא בעד ואביין אן אלשוא פיהמא הו סאכן וליס הו מתחרך

II.L.2.12.3.3. ואיצא פאן אלגעיה ליסת הי באלואגב תחת אלחרוף כמא יגב ללמלך ואלשוא לאן אלגעיה אנמא הי תנפס פי אלכלאם פחדפהא ממכן ואלקאר מכייר פי קראתהא אלא פי מואצע ליס 


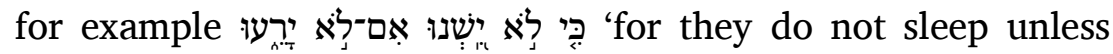
they do wrong' (Prov. 4.16), because the ga'ya makes it into the lexical class of 'slumber and sleep'. If it were lacking, it would

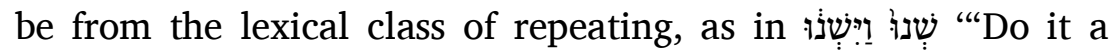
second time" and they did it a second time' (1 Kings 18.34). This applies also to the lexical classes of 'fearing' and 'seeing'.

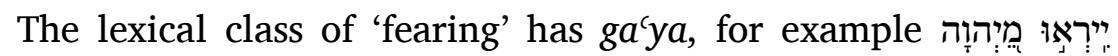
'Let them fear the Lord' (Psa. 33.8). Although here it has two

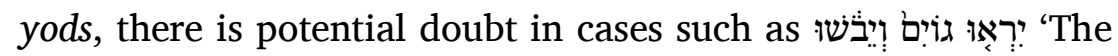
nations will see and be ashamed' (Micah 7.16). If this is the case, the occurrence of gaya in the lexical class of 'fearing' prevents it. To these can be added further examples in which the reader does not have a choice. Cases in which the reader

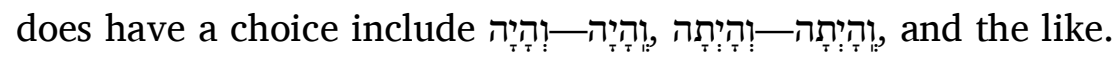
Such cases do not attain the status of the vowels and the shewa, because the construction of a word is based on the vowels. Its construction is not based on the gaya. For this reason the scholars of language in this discipline say 'The ga'ya has no principle'. For these reasons, when there is a need for lengthening, you mark a ga'ya with shewa and you do not mark patah by itself. This is the appropriate response to the question.

\section{II.L.2.12.4. The Fourth Subsection}

\section{II.L.2.12.4.1.}

When shewa is under a letter, it is not possible for any of the disjunctive or conjunctive accents to be under this letter, so long as shewa is under it, since it is a principle of shewa that it does not combine with an accent on a letter in any circumstances. If 
אלקאר פיהא מכייר נחו כי לא יִשנו אִם לא יִירעו לאן אלגעיה (L4:6v) אלתתניה כקוֹ שנו וישנו ומתל דלך לגה אלכשיה ואלנטר אלדי לגה אלכשיה בגעיה כקוֹ > יייראו > מייי ואן כאנת ביודין פלא יומן מן חצול אלאלתבאס פי מתל יראו גוים ויבשו פאן וקע כאן תבות אלגעיה פי לגה אלכשיה תמנע מנה אלי גיר דלך ממא לא ימכן אלקאר אלכיאר פיה וממא ימכן אלקאר אלכיאר פיה וְהָיָיה

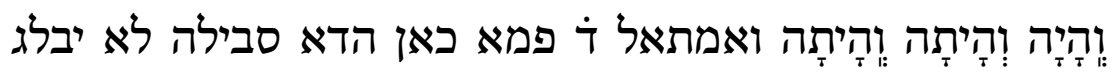
מבלג (L5:6r) אלמלוך ואלשוא לאן בניה אלכלאם עלי אלחרכאת וליס בניתה עלי אלגעיה ולדלך יקולון אהל אללגה אלדי להדא אלעלם אין אב ללגעיה פמן אגל הדה אלוגוה אדא אחתיג אלי אלתתקיל געלת אלגעיה מע אלשוא ולא תגעל פאתחה וחדהא והדא אלדי לאח פי גואב הדה אלמסלה פ פנא דं.L.2.12.4. II.L.2.12.4.1. אלשוא אדא כאנת תחת חרף אמתנע אן יכון תחת דלך אלחרף שיא מן אלאלחאן ואלכדאם מהמא אלשוא תחתה לאן מן חכם אלשוא אלא יגתמע הו וטעם (L5:6v) פי חרף בתה פאן קאל ולם 
somebody says: 'Why is that, when you have not denied that the combination of a shewa and an accent on the same letter is possible, although we do not find them combined?', the response to him would be as follows. Even if the shewa of both categories, i.e. quiescent and mobile, were to combine (with an accent), the combination of an accent with quiescent shewa could not take place, since it is the principle of the quiescent shewa that it makes the letter quiescent and does not move at

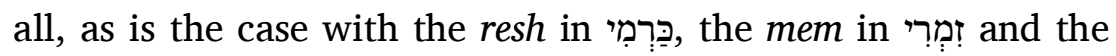
bet in טַבְּד A disjunctive accent and a conjunctive accent by their nature cause the letter to move (with a vowel) and introduce a melody or melodies in it. A quiescent letter cannot have a melody at all. A melody is movement, so how can a quiescent shewa be also mobile at the same time? Is this not a contradiction? So this is impossible.

\section{II.L.2.12.4.2.}

If somebody were to say 'Although the combination of an accent with a quiescent shewa is impossible, it would be permissible for one to be combined with mobile shewa, because there is no contradiction', the response to him would be as follows. The statement that an accent moves a letter with a vowel does not imply that its movement is like that of shewa. This is because shewa makes a letter mobile, but causes its articulation to be quick, so that one cannot tarry on the letter, like the bet in 'in the beginning', since it is not permissible to hold onto it when the speaker wishes to express his intention. Likewise dalet in דִּרוֹר 'liberty', and the șade in 'bundle', in which the shewa causes the letter to move quickly with a speed that does not allow tarrying on it. This is not the case with an accent, which, rather, causes the letter to have a vowel and introduces melodies into it. The letter is given a vowel in its place without moving back or forward so long as it is given a melody. Surely 
דלך ומא אנכרת אן אגתמאע אלשוא ואלטעם פי חרף ואחד יצח ואן כאן לא נראהמא מגתמעין קיל לה לו אגתמע אלשוא מן אלקסמין אלמדכורין והמא אלסאכן ואלמתחרך פאגתמאעה מע אלסאכן לא יתם לאן אלסאכן מן חכמה אן יסכן אלחרף ולא יצטטרב בתה כאלריש מן כרְמי ואלמאם מן זמְרי ואלבא מן עבְדי ואללחן ואלכאדם מן שאנהמא (L5:7r) אן יחרכא אלחרף ויגעלא פיה נגמה ונגמאת ואלחרף אלסאכן לא יצח פיה נגמה בתה ואלנגמה הי אלחרכה פכיף יכון אלסאכן מתחרכא פי חאל ואחד פאליס הדא מנאקצה פקד אסתחאל דלך

II.L.2.12.4.2. 960 אלסאכן פיגוז אגתמאעה מע אלשוא אלמתחרך לאן מא תם מנאקצה קיל לה ליס אלקול באן אללחן יחרך אלחרף יקתצי אן תכון חרכתה כחרכה (L5:7v) אלשוא ודאך אן אלשוא יחרך אלחרף ויסרע בנטקה חתי לא ימכן אחד אן ילבת בדלך אלחרף כאלבא מן בראשית אדי לא יצח מסכה וללמתכלם גרצא פי 965 אלכלאם וכדלך אלדאל מן דרור ואלצאד מן צרור פאלשוא יסרע באלחרף סרעה לא ימכן אלתבאת מעהא וליס כדלך אללחן בל הו יחרך אלחרף ויגעל פיה נגמאת ואלחרף פי מוצעה יתחרך לא ירגע אלי כלף ולא אלי קדאם מהמא אלחרף ינגם 
you see how it (the accent) gives the resh a melody in 'they made haste' (Josh. 8.14) and the letter does not move from its place. The accent has given it a melody, or two or more. One does not tarry on the dalet in דִ דִ and the like (with shewa) in

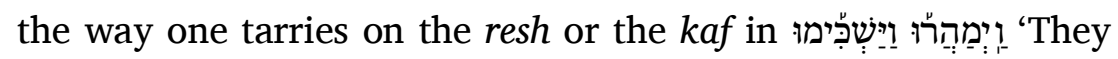
made haste and rose early' (Josh. 8.14). The shewa moves quickly forwards whereas an accent causes vocalic movement within its place. If these were to combine there would be a logical contradiction. It is, therefore, clear from this that shewa and an accent cannot combine together in a single letter.

\section{II.L.2.12.5. The Fifth Subsection}

A mobile shewa is not followed by a letter with dagesh, for

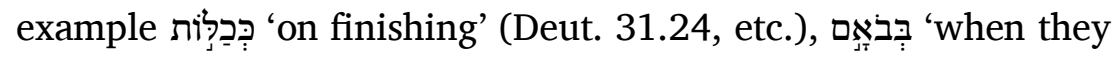

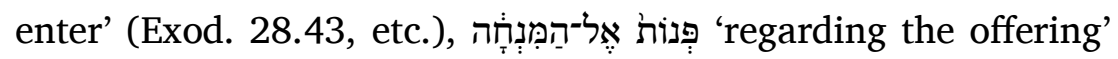
(Mal. 2.13), בְָּ 'in all', and the like. This is not contradicted by

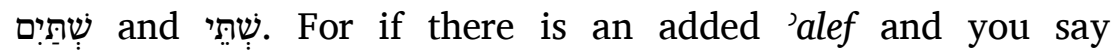

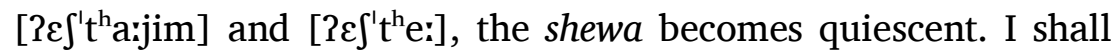
discuss this at greater length in the section concerning yetiv with the help of God and His good will. If one were to say 'Why is shewa not followed by a letter with dagesh?', the response to him would be as follows. The principle of dagesh is to make a letter heavy and give it a kind of quiescence. A mobile shewa is not dwelt upon and so the letter that is after it must be light. When the letter that is after it is heavy, it is not possible to give it the mobility to the extent that I have mentioned.

\section{II.L.2.12.6. The Sixth Subsection}

Mobile shewa does not combine with a vowel on a letter of the alphabet with the exception of the four letters

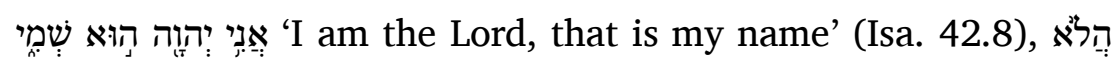


970 אלי תרי כיף ינגם אלריש L55:8r) מן וַיְמַהַרו ואלחרף מן מוצעה מא ברח וקד חרכה נגמה ותנתין ומא זאד ואלדאל מן דרור ומא מאתלה לא ילבתה לבת אלריש ואלכאף פי וַיְמַהַרֵו וַישְִִׁימו פצאר אלשוא יתחרך בסרעה אלי קדאם ואללחן יחרך פי אלמוצע בעינה פלו אגמתע לכאן דלך מתנאקצא פבאן מן דלך אן שוא ולחן לא יגתמעא פי חרף ואחד מעא

II.L.2.12.5. אלשוא אלמתחרך לא יכון בעדה חרף דגש כקוֹ כְּכּלוֹת בְּבוֹאָּם

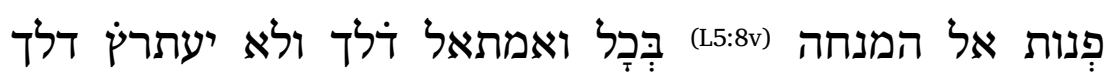

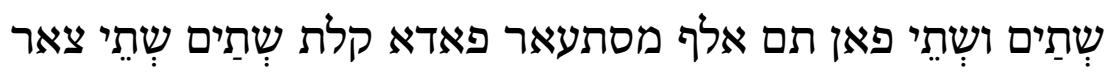
980 אללה ומשיתה פאן קאל לם לא יכון בעד אלשוא חרף דגש קיל לה אן מן חכם אלדגש אן יתקל אלחרף ויגעל פיה צרבא מן

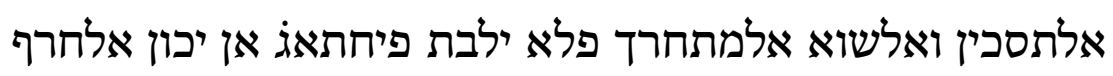
אלדי בעדה כפיפא פמתי כאן אלחרף אלדי בעדה תקיל לם 985

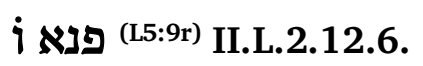
אלשוא אלמתחרך לא יגתמע מע מלך פי חרף מן חרוף אלף בית אלא פי ארבע חרוף אָהחעע כקוֹ אֲנִי ייי הוא שמי הֶלא הֶוא 


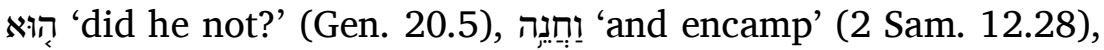

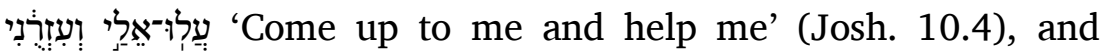
similar cases. If one were to say 'Is not shewa combined with

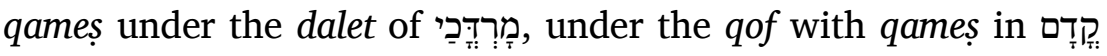
'before', מָדָָמֵיהוֹן 'before them', under the mem with qames in

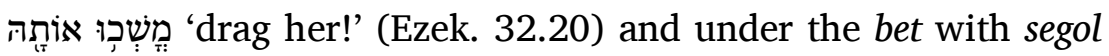

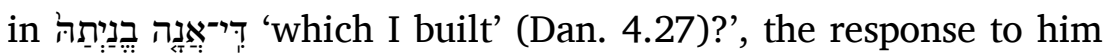
would be as follows. This does not contradict what I stated. This is because the people responsible for this matter have agreed on the rule of combining shewa and a vowel only under the four letters. It is said, however, that some scribes wanted to remove uncertainty from places that may lead to error and have combined a vowel with shewa in this way, because they thought

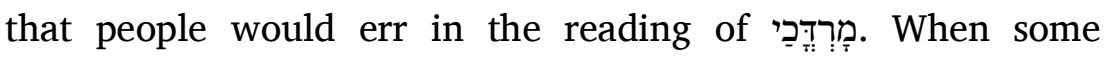
people saw shewa without qameș in מָרְִ they read it as patah. If they saw qames alone, they were at risk of giving the qames its full length. So, the scribes decided to combine them so that this degree of uncertainty be removed. This applied also to similar cases (cited above). This is an exception to their customary practice. What supports the claim that this is the view of only some of them with regard to letters not belonging to the group of the four (אنंغن) is that in most codices one does not find what has been presented as counterevidence, but all codices are uniform in the combination of shewa with a vowel under the four letters.

\section{II.L.2.12.7. The Seventh Subsection}

When shewa is combined with a vowel in a letter, the vowel is

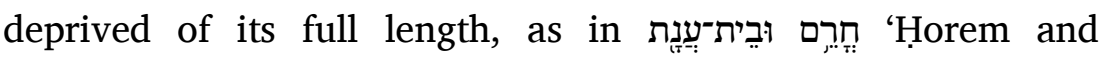
Betanath' (Josh. 19.38), in which the het is pronounced with a short vowel on account of the shewa that is with the qames. The same applies to 'also every sickness' (Deut. 28.61), in which shewa is combined with the vowel and the vowel has 
וַחְנֵּה עַלוּ אלי ועז ואמ דלך פאן קאל אליס קד אגתמע אלשוא

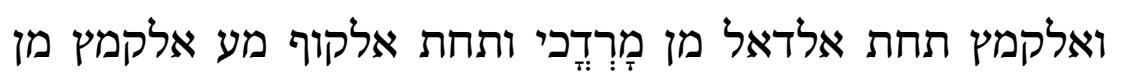

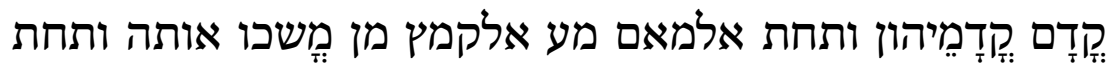
אלבא פי די אַנָה בְנְניָתָה מע אלסגולה קיל לה ליס דלך בנאקץ למא דכרתה ודלך אן אהל הדא אלשאן אצטלחו אן לא יגמעו (L5:9v) אלשוא ואלמלך אלא תחת הדה אלארבעה חרוף ואנמא קיל אן בעץ אלסופרים אראד אן ירפע אלאשכאל מן אלמואצע אלמגלטה פגמע אלמלך מע אלשוא להדא אלוגה לאנה ראי אלנאס יגלטו פי קראה מרדכי פמנהם מן אדא ראי אלשוא בלא קאמצה קראהא מפתוחה ואן ראי אלקאמצה וחדהא לם יאמן אן יסתופי אלקאמצה פראי אן יוֹמעהמא חתי ירפע הדא 1000 ואלדי יקוי אן (L5:10r) הדא ראי אלבעץ מנהם פי גיר אלארבעה חרוף הו אן אכתר אלמצאחף לא יוגד פיהא מא אעתרץ בה אלמעתרץ ואלמצאחף כלהא מטבקה עלי גמע אלשוא ואלמלך תחת הדה אלד חרוף

l I I.L.2.12.7. 1005 אלשוא אדא אגתמע מע מלך פי חרף סלב אלמלך חטה מן אן יסתופא כקוֹ חָרֵם ובית עַנָת גָא אלחית כפיפא לאגל אלשוא אלדי מע אלקאמצה וכדלך גֶם כָל חָלי גָא אלשוא מע אלמלך 
become short. If it were said 'Why is it that when shewa is combined with a vowel under a letter, the vowel is deprived of its full quantity?' the response would be as follows. This is because when there is mobile shewa, it is not permissible to slow down on or dwell on the letter. This is a principle that cannot be avoided. When they both occur under a letter, its principle holds, namely moving forward quickly, and so it is not possible for the vowel to be given its full quantity. This is determined by the principle of the shewa. If somebody were to say 'Just as the shewa has an unavoidable principle, likewise a vowel has an indissoluble feature, namely slowness and steadiness, so why is the vowel not more worthy of fulfilling its principle than something else?', the response to him would be as follows. If they wanted to maintain the principle of the vowel, they would not have combined it with shewa, since that would be nonsense. Rather they combined them in order for the principle of the vowel to be eliminated. The combination of the two principles is impossible, just as is the elimination of the two principles. It is necessary to maintain one of them, and this is the principle of the shewa. If somebody were to say 'With how many vowels does shewa combine?', the response would be: with three, qames, patah and segol. If he said 'Why is it combined specifically with these three and not the others?', the response would be: because with these three vowels it is permissible to melodize, pause and read quickly, whereas this is not possible with the other vowels. 
כאן אלמלך כפיפא פאן קאל ולם כאן אדא (L5:10v) אغתמע 1010 אלשוא מע מלך תחת חרף סלב דלך אלמלך חטה קיל לה לאן אלשוא אלמתחרך לא יצח פיה אלתבאטי ואללבת פי אלחרף והדה עלה לא יצח אנפכאכה מנהא פאדא חצלא גמיעא תחת חרף תבתת עלתה והי אלנהוץ בסרעה פלא ימכן אלמלך אן יסתופי חטה פיכון דלך מקצא לעלה אלשוא פאן קיל כמא אן ללשוא עלה לא תפארקה כדלך ללמלך עלה לא תפארקה והי אלתבאטי ואלתבאת פלם לא כאן אלמלך (L5:11r) באסתיפא עלתה אולי מן סואה קיל לה לו אראדו אן יתבתו עלה אלמלך לם יגמעו מעה אלשוא אד כאן דלך עבת ואנמא גמעוהא לתזול עלה אלמלך ואגתמאע אלעלתין מסתחיל ואנתפא אלעלתין כדלך פלא בד מן תבות אחדהמא והי עלה אלשוא פאן קיל פמע כם מן אלמלוך תגתמע אלשוא קיל לה מע תלאת אלקאמצה ואלפאתחה ואלסגולה פאן קאל ולם אכתץ בהדה

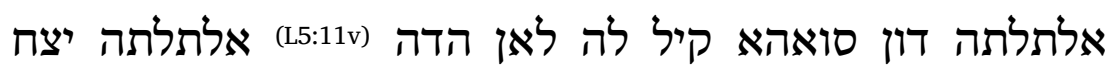
פיהא פי אלתנגים אלתוקף ואלסרעה ומא סואהם לא יתם פיה 


\section{II.L.2.12.8. The Eighth Subsection}

\section{II.L.2.12.8.1.}

When shewa is at the beginning of a word, it is always mobile,

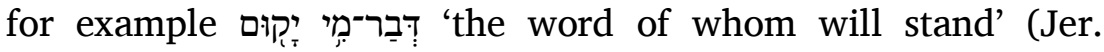

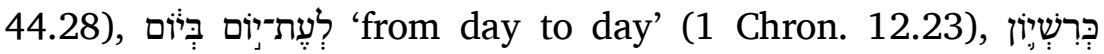

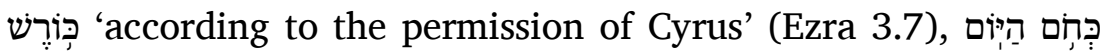
'in the heat of the day' (Gen. 18.1), and similar cases. If somebody were to say 'Why have you claimed that quiescent shewa never occurs at the beginning of a word?', the response would be that a quiescent shewa is the stopping point of what precedes it, and the beginning of a word has nothing before it,

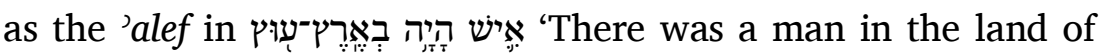

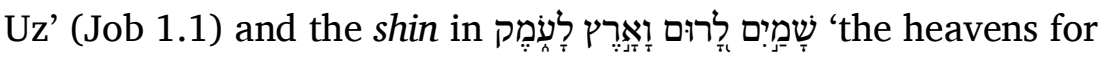
height, and the earth for depth' (Prov. 25.3), and similar cases. And if somebody said 'Do you not say that every shewa beginning a word is mobile, but we find a mobile shewa that is

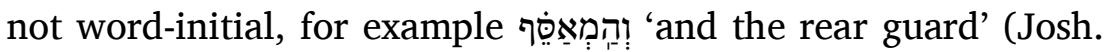

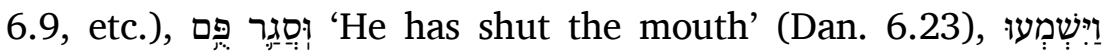

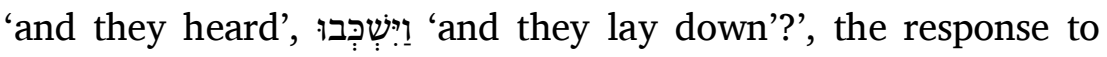
him would be as follows. When I said that every shewa at the beginning of a word is mobile, this does not oblige me to claim that a mobile shewa is found only in word-initial position. Indeed a mobile shewa may be in the middle of a word. This claim would, however, be contradicted if a shewa that is not mobile is found in word-initial position. Yet in the examples that I have adduced, and others like them, they are in initial position in the sense that they are preceded by quiescence and a stopping point. 
פנא

II.L.2.12.8.1.

אלשוא אדא כאן פי אול אלכלאם אבדא יכון מתחרך כקוֹ דבבר מִי יָקום לְֵֵת יוֹם בְיוֹם כְרְשׁיוֹן כוֹרש כְחם היום אלי גיר דלך פאן קאל ולם זעמת אן אלשוא אלסאכן לא יכון פי אואיל אלכלם 1030 אבדא קיל לה אן אלסאכן הו מחט למא תקדמה ואבתדא אלכלאם לא יכון קבלה שי כאלאלף מן איש היה בארץ עוץ ואלשין מן שמים (L5:12r) לָרום וָאָרץ לָעומק אלי גיר דלך פאן קאל אליס תקול אן כל מבתדא מתחרך ונחן נגד אלמתחרך פי

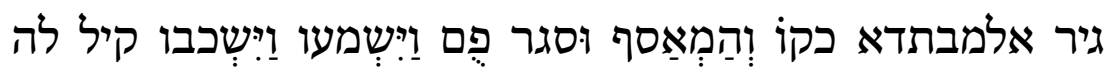
ליס אדא קלת אן כל שוא פי בדו אלכלאם מתחרך ילזמני אלא

יכון מתחרך אלא פי אלאבתדי בל קד יכון פי אלתוסט מתחרך ואנמא כאן יעתרץ דלך לו וגד שוא פי אלאבתדא גיר מתחרך ומע דלך אן אלמואצע אלדי דכרתהא ומא מאתלהא פהי כדלך מבתדאה עלי (L5:12v) וגה מן חית אן קבלהא סכון ומחט 


\section{II.L.2.12.8.2.}

If somebody were to say 'So do you say that a letter by itself can have the status of a word and have mobility and quiescence, but this is a contradiction with regard to a single letter, so according to this וֹסְגֵ could not have a mobile shewa until the shewa becomes mobile after quiescence, as you say?', the response would be as follows. The stopping point may be a quiescent

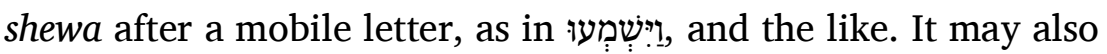
be what is analagous to it and may be called a stopping point, namely the introduction of heaviness to a letter. This may cause

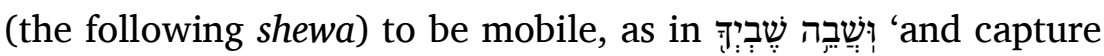
your captives!' (Jud. 5.12), in which the heaviness of the vav has the status of a word with two letters, so the shewa is mobile on account of this. The heaviness of the letter corresponds to quiescence of a shewa and becomes a stopping point, as in

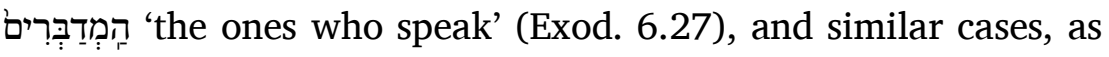
will be explained in the discussion about he and mem below.

\section{II.L.2.12.9. The Ninth Subsection}

A mobile shewa is followed by quiescence only in a letter that is not less than the third letter after it. Quiescence in a letter that is greater (in number than the third) is possible, but the minimum for quiescence is the third (letter after the mobile

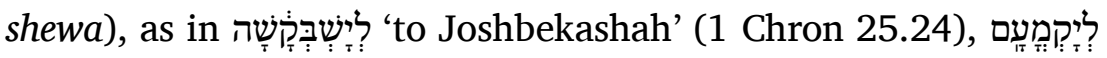
'to Jokmeam' (1 Kings 4.12), and the like. Examples of quiescence in a letter that is greater than the third (after the

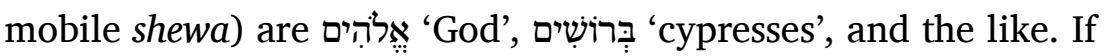

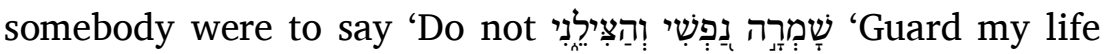

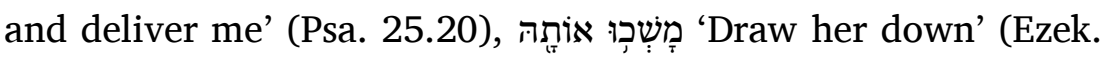


II.L.2.12.8.2.

1040 פאן קאל אפתקול אן אלחרף וחדה יקום מקאם לפטה פיכון פיה אלתחריך ואלסכון והדה מנאקצה פי אלחרף אלואחד פלא יגוזוז על הדא אן יכון וּסְגר >מתחרד> חתי יתחרך אלשוא בעד אלסכון עלי קולך קיל לה אן אלמחט קד יכון סאכן בעד מתחרך מתל קו וישמעו ונחוה וקד יכון מא יגרי מגראה יסמי מחט והו

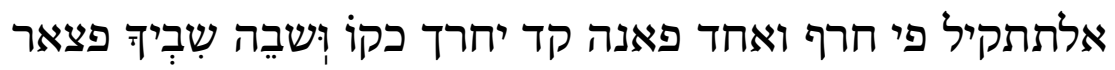
אלתתקיל פי (L5:13r) אלואו ינוב מנאב לפטה פיהא חרפין פיתחרך אלשוא לדלך אלתתקיל מן דלך אלחרף לסכן אלשוא וצאר מחט מתל הֵם הַמְדברים ונחוה עלי מא יגי אלכלאם פי הא ומאם משרוחא מן בעד פנא II.L.2.12.9. 1050 אלשוא אלמתחרך לא יכון בעדה סכון אלי אקל מן אלחרף טיףזיר אלתאלת ומא זאד ען דלך ממכן לכן אקל מא יכון מן אלסכון עלי אלתאלת כקוֹ לְיְשְבָָָָה לְיָקמעָם ונחוה ואמא מא זאד על אלתאלת פי אלסכון מתל אלהִים בְרוֹשִׁים ונחוהמא (L5:13v) פאן 1055 קאל אליס שָמְרָה נפשי והצילני ומשכו אותה ומא גרי 
32.20) and analogous cases refute the principle that you have formulated?', the response to him would be as follows. I spoke only about shewa that is present under a letter. Cases of shortness and lightness that have been transmitted by teaching from the people of the language are not relevant for this argument.

\section{II.L.2.12.10. The Tenth Subsection}

Mobile shewa does not occur adjacent to another mobile shewa at the beginning, middle or end of a word, for if they were adjacent, the word would be defective. This is because a word must consist of a letter with a vowel and what is attached to the letter with a vowel by way of an initial mobile shewa is of a lesser vowel movement than the following vowel. These two may be followed by a quiescent consonant. This structure cannot be broken. Therefore, two mobile shewas are not linked together, as two quiescent shewas are.

\section{II.L.2.12.11. The Eleventh Subsection}

Two quiescent shewas cannot follow one another at the beginning of a word or in the middle of it. If somebody were to say 'Why is this so?', the response to him would be: because the first shewa is quiescent on account of it being the stopping point of what precedes it. The second shewa, however, is not preceded by a letter with a vowel, for which the second shewa would be a stopping point. For this reason, two quiescent shewas are not linked together in the places mentioned.

\section{II.L.2.12.12. The Twelfth Subsection}

When there are two shewas following one another, a sequence in which the first is mobile and the second quiescent is not permissible, rather the first must be made quiescent and the 
מגראהמא קד ינקץ מא בניתה מן הדא אלאצל קיל לה אנמא תכלמת פי אלשוא אלחאצר תחת אלחרף ואמא מא תסלם כטפה וכפתה מן אהל אללגה תלקינא לם יכון פי הדא אלכלאם

פי שי

; פנא II.L.2.12.10. 1060 שוא מתחרך לא יגאור שוא מתחרך לא פי אול אלכלאם ולא פי וסטה ולא פי אכרה לאן לו תגאורא לאנפסד אלכלאם ודאך אן אלכלאם אנמא יכון מתחרך (L5:14r) ומא ילחק אלמתחרך פהו אקל חרכה מן אלמתחרך אדא אבתדאה באלשוא ואלסאכן קד 1065 יתבעהמא והדה בניה לא יגוז נקצהא פלדלך לם יקתרנא מתחרכין כמא יקתרנא אלסאכנין

פנה יא שְוָאֵין סאכנין לא יגוז תראדפהמא לא פי אול אלכלאם ולא פי וסטה פאן קאל ולם כאן דלך קיל לה לאן אלשוא אלאול אנמא 1070 סכן לכונה מחט למא תקדמה ואלתאני פלם יתקדמה חרף מתחרך פיכון אלתאני מחט לה פלדלך לם (L5:14v) יקתרנא אלסאכנין פי אלמוצעין אלמדכורין

II.L.2.12.12. שְוְוָאין מתראדפין אלאול מתחרך ואלתאני סאכן לא יגוז 1075 תראדפהמא אלא אן יכון אלאול ללסאכן ואלתאני ללמתחרך 
second mobile. If somebody were to say 'Why is that?', the response to him would be as follows. When the first shewa is mobile, it is not permissible for it to be followed by a quiescent letter, because if that were the case, the mobile shewa would not have scope to spring forward quickly. It has been stated previously that quiescence cannot occur on less than the third letter after a mobile shewa. Furthermore it is not possible to pronounce a mobile shewa followed by a quiescent shewa for the reason just mentioned, whereas a pronunciation of a quiescent shewa in the first letter and a mobile shewa on the second letter is acceptable, as in Iִ Iִ 'and they gathered', and the like. Take note that shewa may be construed as a successive sequence (of two) even though only one is written. This applies to cases such

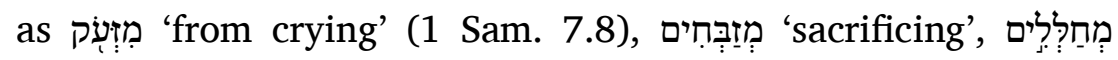

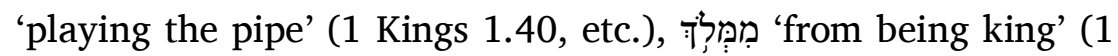
Sam. 8.7, etc.). The shewa here is pronounced mobile. The reason for this is that the letter is pronounced as two letters. This is the custom of Hebrew, namely that every letter with strengthening, I mean with dagesh, in the middle of a word, where it does not have the status of beginning (a word or syllable), under which there is shewa, is pronounced as two

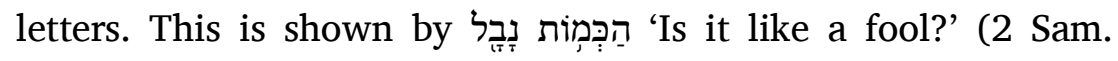

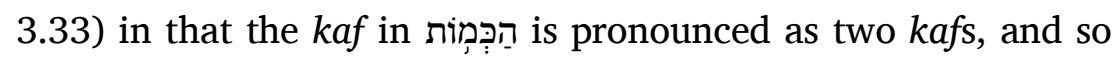
in other cases. The dagesh on the letter, therefore, is in place of the quiescent shewa and the shewa that is present under the letter is mobile, and so it is pronounced as two letters.

\section{II.L.2.12.13. The Thirteenth Subsection}

A shewa at the end of a word can only be quiescent, as in 'way', מֶלֶּ 'king', and the like. 
פאן קיל ולם דלך קיל לה אדא כאן אלשוא אלאול מתחרך לא יגוז יכון בעדה חרפא סאכנא לאנה אן כאן דלך לא יציב אלמתחרך פסחה ללנהוץ וקד תקדם אלכלאם אן לא יכון בעד אלשוא אלמתחרך סכון פי אקל מן אלחרף (L5:15r) אלתאלת 1080 ואיצא פאן אלמתחרך ובעדה אלסאכן לא יצח אלנטק בהמא עלי אלוגה אלמדכור בל אלנטק באלסאכן פי אלאול ואלמתחרך פי אלתאני מפהומא מתל ויקְבְצו ונחוה ואעלם אן תם שוא בניתה עלי אלתראדף ואן כאן ליס אלא ואחד מכתוב והו נחו קוֹ מִזְעוֹק מזבְחים מחלְלים ממלוך פאן אלשוא כרג כאלמתחרד 1085 ואלסבב פי דלך לאן אלחרף כרג בחרפין פהדה סירה פי אלעבראני והו אן כל חרף משדד (L5:15v) אעני מדגוש פי וסט כלמה בחית לא יגרי מגרי אבתדא ותחתה שוא יכרג בחרפין יביין דלך קוֹ הכְמוֹת נָבָל והו אן אלכאף פי הכמות כרֹ בכאפין אלי גיר דלך פיכון אלדגש פי אלחרף מקאם אלשוא אלסאכן ויכון אלשוא אלחאצר תחת אלחרף מתחרך ולדלך כרג בחרפין

פנא יוֹ II.L.2.12.13. אלשוא פי אכר אלכלאם לא יכון אלא סאכנא נחו דרך מלך

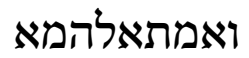




\section{II.L.2.12.14. The Fourteenth Subsection}

Two successive silent shewas occur only at the end of a word, as

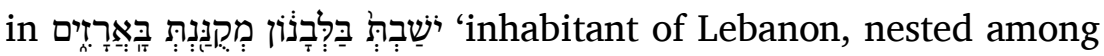

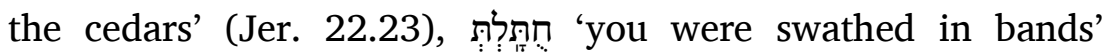

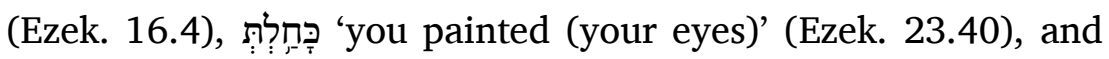
similar examples. A shewa at the end of a word indicates feminine gender in many cases, both when following (another shewa) and also when not in such a sequence. In some cases shewa does not indicate feminine gender but rather pause, as in

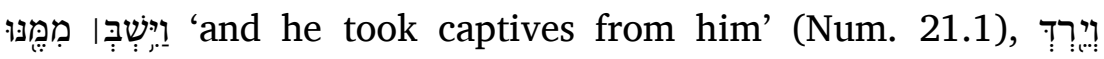

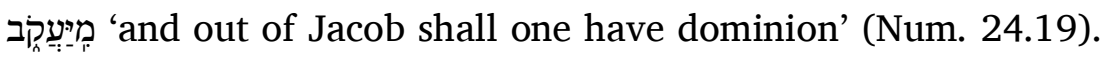
If somebody were to say 'What is the value of the two successive shewas at the end of a word?', the response would be as follows. One is a stopping point, namely the first one, as in כִבוּרָּה 'and you sat on a stately couch' (Ezek. 23.41). The bet in iִ ְישׁׁב is the end of a word expressing the masculine singular. The second shewa under the tav indicates the feminine gender. You will find this practice in many places.

\section{II.L.2.13. Section (concerning Uncertainty regarding the Reading of the Shewa)}

\section{II.L.2.13.1.}

The shewa may be the cause of uncertainty for the reader in some places as to whether it is mobile or quiescent. (This applies to) הַמ. It has been stated previously that in words containing not more than five letters the shewa is mobile, as in

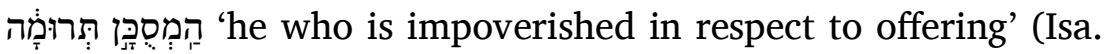

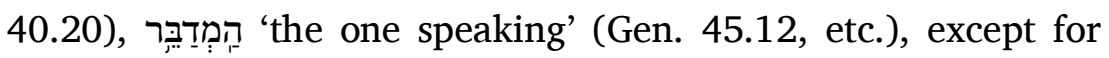

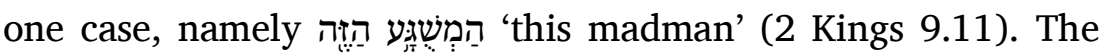
reason why it is not mobile is that there is no heaviness in the he. If you were to give heaviness to the he, the shewa would be 
II.L.2.12.14.

1095

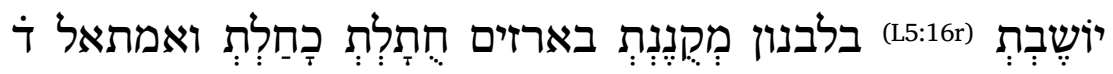
ואלשוא פי אכר אלכלאם קד ידל עלי אלמונת פי אכתר אלמואצע פי אלתראדף וגיר אלתראדף ותם שוא לא ידל עלי אלמונת בל עלי קטע כקוֹ וַיְשׁבד ממנו ויוְרְד מיע פאן קאל ומא 1100 אלואחד מחט והו אלאול כקוֹ וְישַבבְת על מטה כבודה פאלבא מן וישְשַבְ הו נהאיה כלמה ללמדכר ואלשוא אלב אלדי תחת אלתו דאל עלי אל (L5:16v) תאנית והדה אלסירה תגדהא פי כתיר מן אלמואצע

פצל II.L.2.13.

II.L.2.13.1. אלשוא קד ישכל פי מואצע עלי אלקאר הל הו מתחרך אם הו סאכן הַמְ וקד תקדם אלקול אן מא כאן מן אלכלם אלדי עדד חרופהא כמסה לא אזיד פאן אלשוא יכון מתחרך נחו המְסְכָן תרומה הַמְדָבֵּר מא סוי מוצעע ואחד והו הַמְשְָׁגע הזה ואלסבב פי 1110 
made mobile. As for words beginning with he and mem that have more than five letters, the rule concerning these is that if the accent is on the fifth letter or later, the shewa is silent, for

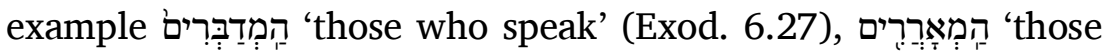
who curse' (Num. 5.19), apart from some exceptions that

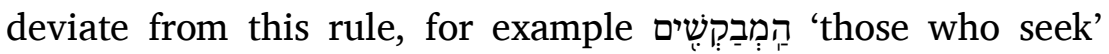
(Exod. 4.19, etc.), and the like. When the accent is on the fourth

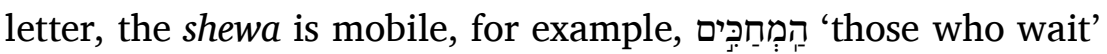
(Job 3.21), הָמְנָדָדים 'those who remove' (Amos 6.3), and the like.

\section{II.L.2.13.2.}

As for a series of two successive identical letters in the middle of a word that one may be uncertain about, this has been discussed above. The (reading of the shewa) is determined by

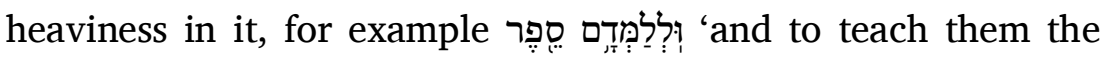
writing' (Dan. 1.4). If the heaviness was removed from the vav, the shewa would not be pronounced like patah. There are six

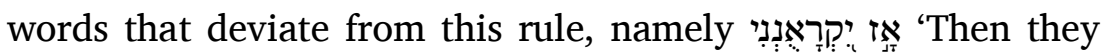

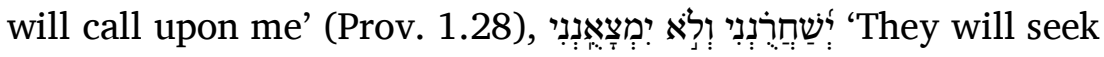

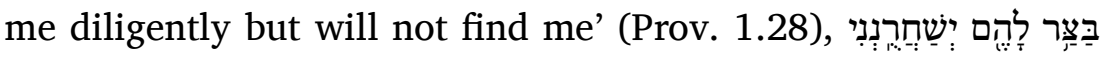

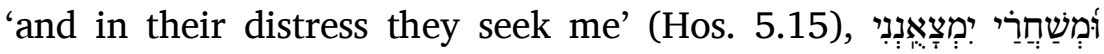

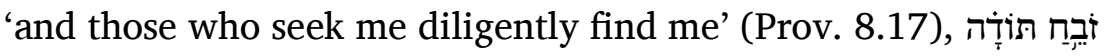

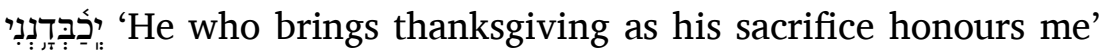
(Psa. 50.23).

\section{II.L.2.13.3.}

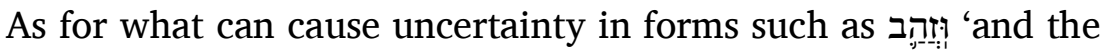

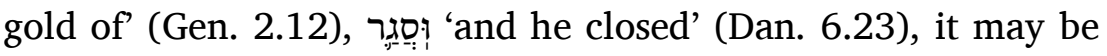
said concerning cases that are linked to what follows by the

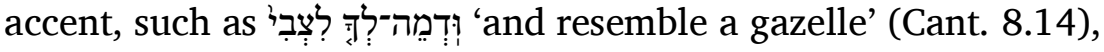

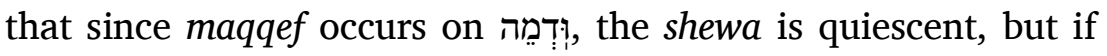


לתחרך אלשוא ואמא מא יזיד ען כמסה חרוף מן אלכלם (L2:6r) אלתי אולהא הַא ומֵאם פאלשרט פי דלך הו אן אן כאן אללחן עלי אלחרף אלה ומא זאד כאן אלשוא סאכן מתל הַמְדַבְרִים הַמְאָרְרִים אלא שואד כארג ען דלך מתל הַמְבַקְשִׁים ונחוה ואדא כאן אללחן עלי אלחרף אלד כאן אלשוא מתחרך (L7:1v)

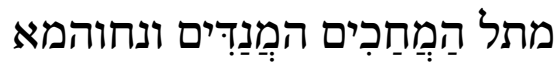

II.L.2.13.2. ואמא מא ילתבס מן אלחרפין אלמתראדפין פי וסט אלכלאם פקד תקדם אלקול פיה איצא והו אן אלתתקיל שרט פיה כקוֹ וּלְלְלְמדדם סֶפֶר ולו זָאל אלתתקיל מן אלואו לם יפתח אלשוא ואלדי כרג ען דלך סת לפטאת והי אָז יִקְרָאונְני יְשְחָרונְנִי ולא

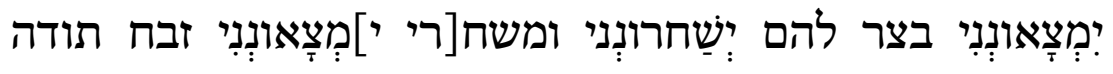

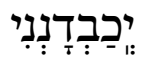

II.L.2.13.3.

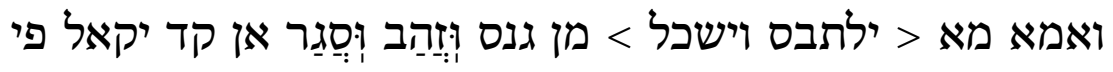

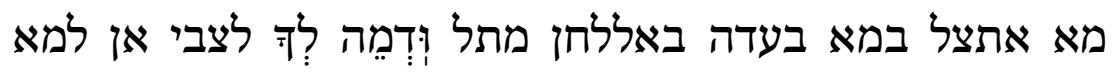
חצל אלמקף פי ודמה סכן אלשוא ואן לו כאן פיה טעם תחרך 
there were an accent on it, the shewa would be mobile, as in

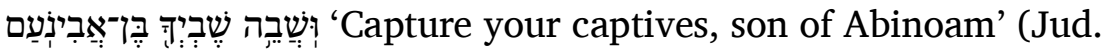

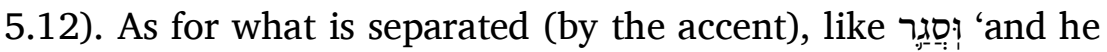
closed' (Dan. 6.23), the heaviness has caused the shewa to be mobile. There are also some cases that are only learnt by listening.

\section{GAP}

\section{II.L.2.14. (Section on the Names of the Vowels)}

[...] the teeth make a squeaking sound with it.

The seventh is shureq [ ] three dots (written) obliquely. It may be replaced by one dot in the middle of vav, whose name is

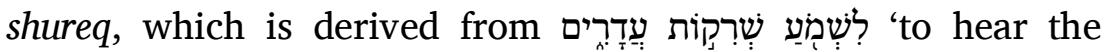
whistlings of the flocks' (Jud. 5.16), which is a whistling, because it gathers the lips together.

\section{II.L.2.15. Section on their Place of Articulation}

\section{II.L.2.15.1.}

The place of articulation of holem is the root of the tongue and the place of swallowing, which is the place of articulation of אהinن, and it moves over the surface of the entire mouth. Take note that if somebody were to investigate carefully their places of articulation, he would have something like the knowledge necessary as to what is first in position and what is last. 


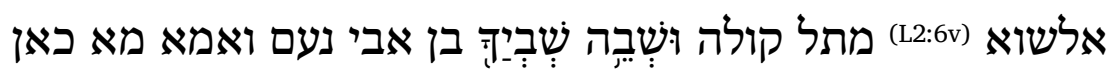

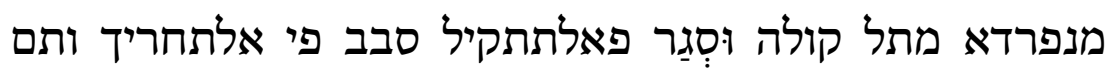
מא לא יוכד אלא סמאעא

GAP

II.L.2.14.

תצר בהא אלאסנאן צרא (L8:101r)

ואלסאבע שרק [ ] ]לתה נקט מוארבה וקד יכון עוצהא נקטה

[ואחדה] פי קלב אלואו אסמוהא שרק ואשתקוה מן שריקות עדרים והו אלצפיר לאנהא תגְמע אלשפתין

Iצ.L.2.15.

II.L.2.15.1.

[מחל] אלחלם עקר הלשון ובית הבליעה [והו מחל] אהतע ומסירה עלי סטח אלפם כלה ואעלם [מן] תאמל מחאלהא צארת לה כאלעלם אלצרורי לה מן דלך אי מא הו אלמתקדם מנהא ואי מ[א הו] אלמתאכר 


\section{II.L.2.15.2.}

The second place of articulation is the place of articulation of qames. It is slightly above the root of the tongue, this being the (first) third of the tongue, and its movement is to above the palate.

\section{II.L.2.15.3.}

The third place of articulation is the place of articulation of patah, which is the surface of the tongue at the bottom (of the mouth).

\section{II.L.2.15.4.}

The fourth place of articulation is the place of articulation of segol, which is the sides of the mouth, and its movement is upon the lower surface of the mouth.

\section{II.L.2.15.5.}

The fifth place of articulation is the place of articulation of sere, which is the teeth, without closure, because it breaks through them.

\section{II.L.2.15.6.}

The sixth place of articulation is the place of articulation of hireq, which is the closure of the teeth with force.

\section{II.L.2.15.7}

The seventh place of articulation is the place of articulation of shureq, which is the lips gathered together (as if for) whistling. 
II.L.2.15.2.

אלתאני מחל אלקאמצה והו פוק אצל אללסאן קלילא והו תלת אללסאן וחרכתהא אלי פוק אלחנך II.L.2.15.3. (L6:1r) אספל

II.L.2.15.4. ואלמחל אלראבע הו מחל אלסגולה והו אגנאב אלפם וחרכתהא עלי סטח אלפם אלספלאני

ואלמחל אלכאמס הו מחל אלצירי והו אלאסנאן בלא אטבאק

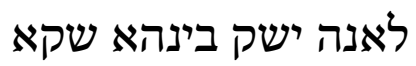

II.L.2.15.6. ואלמחל אלסאדס מחל אלחרק והו אטבאק אלאסנאן בקוה כאלמחל אלסאבע מחל מהל אלשרק והו אלשפתין מצמומתין 
II.L.2.16. Section concerning Combinations of them (i.e. the Vowels) to Form Basic Nouns and Combinations of them to Form Abstractions

For example, אוֹ 'Ono (place name)' (1 Chron. 8.12, etc.), a basic noun (combining) holem with holem and the abstraction אר אis light' (Job 36.30, etc.). Holem with qames: the abstraction טוֹברה (good deed' (1 Sam. 24.19, etc.). Holem with patah: the basic noun רִמֵח 'spear' (Num. 25.7, etc.) and the abstraction הרוֹ 'he made known' (Lev. 4.23, etc.). Holem with segol: the basic noun אה 'tent' and the abstraction with șere: the basic noun בֹּּ 'Bozez (name of a crag)' (1 Sam. 14.4) and the abstraction יוֹציא 'goes out'. Holem with hireq: basic noun עדּפִי 'fault' (Psa. 50.20) and the abstraction (mpl.)'. Holem with shureq: the basic noun 'תהו 'confusion' and the abstraction טוֹבו 'they are good' (cf. Num. 24.5, etc.). To these can be added further examples of this type of (arrangement of vowels), the seven with the seven.

\section{II.L.2.17. Chapter concerning the Descending of the Vowels from One to the Other according to the Order of their Places of Articulation}

Holem descends to qames with the attachment of a pronoun and

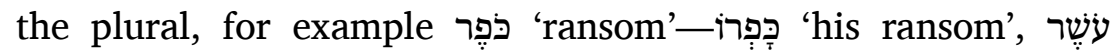

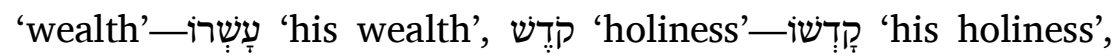

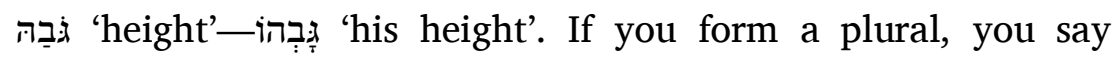
חְדָשִׁים

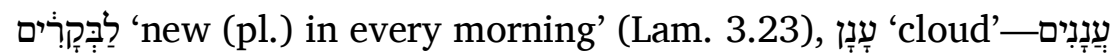

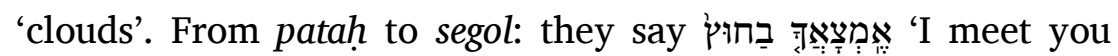

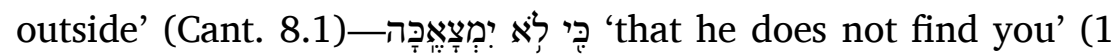
Kings 18.10). From segol to șere in a conjoined form, for example 
פצל אלדי יתלף מנהא אסאס ואלדי יתלף מנהא ערץ II.L.2.16.

מת אוֹנו אסאס חלם מע חלם וערץ אוֹרוֹ חלם מע קאמצה ערץ

טוֹבָה אלחלם מע פאתחה אסאס >רוֹמַח> וערץּ הוֹדַע אלחלם מע אלסגולה אסאס אהל וערץ ויאמֶר אלחלם מע אלצרי אסאס בוֹצֵץ וערץ יוֹצֵא אלחלם מע אלחרק אסאס דוֹפִי >וערץי> עוֹשִים אלחלם מע אלשרק אסאס תהוּ וערץ טוֹבוּ אלי גיר דלך מן צרבהא סבעה פי סבעה

II.L.2.17. תרתיב מחאלהא

אלחלם ינחדר אלי אלקמץ ענד אתצאל אלצמיר ואלגמע נחו

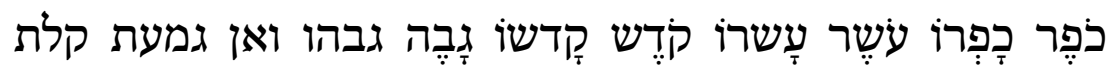
1160 ומן פאתחה אלי סגולה קאלו אַמָָָאָּ בחוץ כי לא ימצֵֶך ומן סגולה (L6:1v) אלי צֶרִי פי אלסמוך מתל ק שֶבֶר תחת על שֶבֶר 


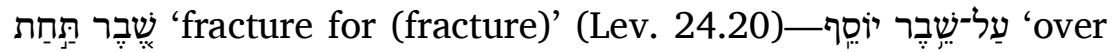
the ruin of Joseph' (Amos 6.6). To these can be added other cases of vowels descending from one to the other in this way.

\section{II.L.2.18. (On the Origin of the Vowels)}

If somebody were to ask 'With regard to the form of these vowels, what is the origin of their formation? Do you say that the scribes established their form?' The response would be as follows. If the scribes were the source of this, it would be permissible for somebody who was not satisfied with it to come and create different forms. This would be permissible for every single scribe. There would be no limit or end to their forms. If one were to say 'Is not the qames of the people of Iraq a superscribed half 'alef, and so forth with regard to the shape of their vowels?', the response would be as follows. What should be relied upon in this regard is (the shape of vowels) in the Holy Land. It is not implausible that when the people of the exile moved away from the Holy Land they made a record of their reading and created shapes (of vowels) when they had moved away from the Holy Land for fear that they would forget the reading. The (original) shapes (of the vowels) of the Holy Land, however, remained. If somebody were to say 'So who formed them?', the response to him would be as follows. It is possible that the people of the language formed the shapes of the vowels just as they formed the shapes of the letters. It is also possible that the people of the language used to use them in conversation without their knowing any (written) form for them until the time of Habakkuk, peace be upon him, when God said to him

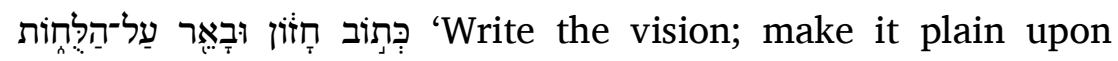
tablets' (Hab. 2.2). He indicated the reason for this, namely 
יוֹסֵף אלי גיר דלך ממא תנחדר מן בעץ אלי בעץ עלי הדא אלוגה - - - - n

II.L.2.18.

פאן קאל אשכאל הדה אלמלוך כיף כאן אצל תשאכילהא אתקולון אן אלסופרים וצעו אשכאלהא קיל לה לו כאן אלסופרים הם אלאצל פי דלך לכאן יגוז אן יגי מן לם ירץ בדלך וישכל אשכאלא סואהא וכאן יצח הדא מן כל סופר וסופר פלא כאן יכון לאשכאלהא לא חד ולא אנקצא פאן קאל אליס אהל אלעראק קאמצתהם נצף אלף מן פוק אלי גיר ד מן אשכאל אנחאיהם קיל לה אן אלמעול פי דלך עלי ארץ הקדושה ומא ימתנע אן למא בעדו אהל אלגולה ען ארץ הקדושה צבטו קראתהם פגעלו להם אשכאל למא בעדו ען ארץ ישראל כוף מן אן ינסו אלקראה ובקית אשכאל ארץ הק פאן קאל פמן שכלהא קיל לה יגוז אן >אהל> אללגה כמא שכלו אשכאל אלחרוף שכלו ללמלוך איצא אשכאל ויגוז איצא אן אהל אללגה כאנו יתכאטבו בהא מן גיר שכל יערפוה להא אלי זמאן חבקוק ע غ פקאל לה אללה כתוב חָזוֹן ובָאָר על הלוחות ואורא אלעלה פי דלך והו למען ירוץ קורא בו ולא שך אן מן אכד מצחאפא 
'so that one who reads it can run' (Hab. 2.2). Indeed, there is no doubt that when somebody takes a simple codex without accents or pointing, he stumbles in the reading and does not 'run', apart from a few exceptional people that are found in some generations, such as Ben Asher and Ben Naftali in their time and those like them. If a reader has a codex in which the cantillation and pointing are clearly indicated, he can run and not stumble.

This is what needs to be said, but God knows best. The discourse is finished. 
1180 אלא אחאד שואד קלאיל יוגדו פי בעץ אלאגיאל כאבן אָשֵר ואבן נפתִִָי (L6:2r) פי זמאנהמא ומן גרי מגראהמא ואדא כאן ללקאר מצחף טאהר אללחן >ואלנקט> הו יָרוּץ ולא יִָּּשֵל הדא מא לאח ואללה אעלם ותמת אלמקאלה 1180 נקט] נטק L6:57r אלנטק L6 1183 ואלנקט] 


\section{II.L.3.0. \\ THE THIRD DISCOURSE: ON THE ACCENTS (SELECTED PASSAGES)}

\section{II.L.3.1. (On the $G a^{c} y a$ )}

If somebody were to say 'So, what do you say concerning the ga'ya?', the response to him would be as follows. The ga'ya does not have a definite status in the reading of Scripture. One reader may omit it and another reader may sustain it. There are some places, however, in which it may not be omitted, since it affects the meaning. This applies to the lexical class of 'fearing', and so they have said 'Every (form from) the lexical class of 'fearing'

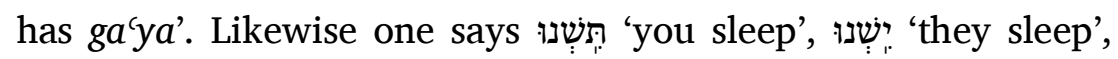

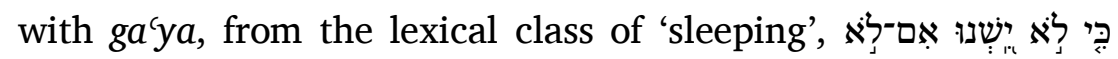
ירעו 'for they cannot sleep unless they have done wrong' (Prov. 4.16). If it is without $g a y a$, it is from (the lexical class) of

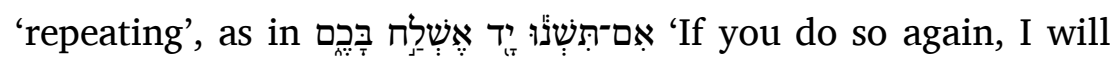
lay hands on you' (Neh. 13.21). If somebody were to say 'So do you consider it to be one of the conjunctive accents or disjunctive accents?', the response to him would be as follows. It should not be considered to belong either with the disjunctive accents or the conjunctive accents, since it is only an exhalation in speech, which carries the words forward, and joins and binds

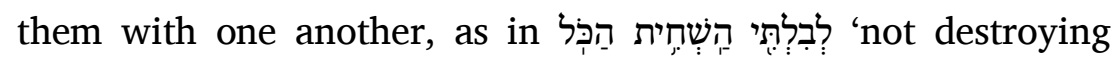

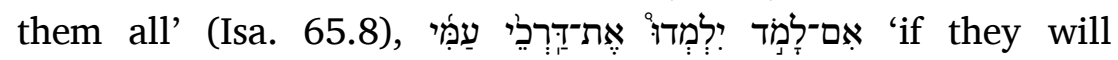
diligently learn the ways of my people' (Jer. 12.16). Its distinctive property is the extension of the melody so that joy is diffused in the heart, in order to conduct the reading along, animating the reader and moving him to read more. An expert of this discipline has said: If you wish to know whether ga'ya is correct, look at the place of the gaya. If it is permissible to put 


\section{II.L.3.0. אלמקאלה אלתאלתה פי אלאלחאן}

II.L.3.1.

(L1:35r) אלגעיה ליס להא שיעור פי אלמקרא פקאר יחדפהא וקאר יתבתהא ותם מואצע לא ימכן חדפהא לאן להא תאתיר פי אלמעני פי לשון יראה וכדא קאלו כל לשון דחילה געי ומתלה 1190 ואדא כאן בלא געיה מן אלתתניה כק אם תשנו יד אשלח בכם פאן קאל פהל תחסבוהא מן אלאלחאן או מן אלכדאם קיל לה מא תחסב לא מע אלאלחאן ולא מע אלכדאם לאנהא אנמא הי תנפס פי אלכלאם ותסוק אלכלם ותוצלהא ותגמעהא בעצהא מע בעץ כק לבלתי השחית הכל אם למד ילמדו את דָרכי עמי וכאציתה אלאמדאד באלנגם לינתשר אלסרור פי אלקלב ולזף אלקראה ולתנשיט אלקאר להא ולתחרכה אלי אלתזייד וקד קאל בעץ עלמא הדא אלעלם אדא ארדת אן תנטר צחה אלגעיה פאנטר מוצע אלגעיה פאן צלח טעם אלכלמה עלי מוצע 
the accent of the word on the place of the gaya, then the gaya is in order. If it does not come in the place of the accent, then return it to the place (of the accent). ${ }^{13} \mathrm{He}$ has said that by this principle one may distinguish a correct ga'ya from one that is incorrect. He then retracted this and said that this principle applies only to certain places. The first statement is the correct one.

\section{II.L.3.2. Chapter concerning Cases whose Rule is not at all Dependent on an Accent and Cases whose Rule is Dependent on an Unspecified Accent.}

\section{II.L.3.2.1.}

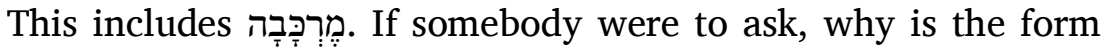
מֶרְָָּבָה sometimes pointed with segol and sometimes pointed with patah, the response would be as follows. When the form is singular, segol occurs under the mem. Examples of the singular

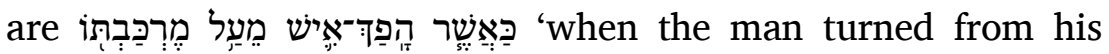

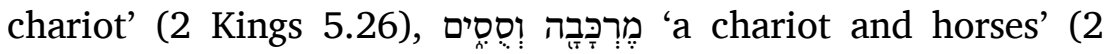

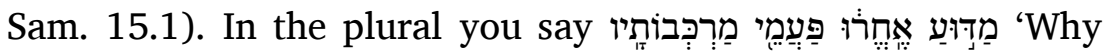

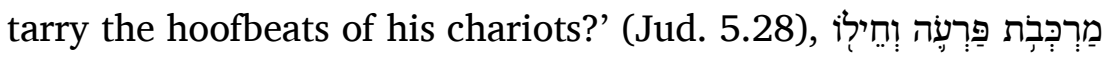
'the chariots of Pharaoh and his army' (Exod. 15.4), and the like. There is one exception to this, in that it does not have segol (in

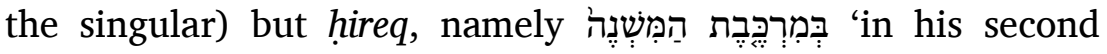
chariot' (Gen. 41.43).

\footnotetext{
${ }^{13}$ The corrected reading פארדהא is a form IV imperative of the root $r-d-d$, which in medieval Judaeo-Arabic is often used with the sense of the form I (Blau 2006, 245).
} 
1200 אלגעיה פאלגעיה מסתויה ואן כאן לא תגי מוצע אלטעם >פארדהא> עלי אלמוצע וקאל אן הדא אלאצל בה יועלם צחה אלגעיה מן פסאדהא ורגע ען דלך פקאל אן הדא אלאצל יצח פי בעץ אלמואצע ואלקול אלאול הו אלצחיח

באב פי מא לם יכון שרטה מעלק בלחן בתה IL1:35v) II.L.3.2. ומא שרטה מעלק בלחן גיר מעיין

II.L.3.2.1. מן דלך לשון מַרְכָבָה אן סאל סאיל לם כאן לשון מֶרְכבה תארה תנקט בתלת נקט ותארה בפאתחה אלגואב הוא אן מא כאן מנהא לשון יחיד כאן תחת אלמאם תלת נקט כק פי אליחיד כאשר הפך איש מעל מֶרְבתו מֶרכבה וסוסים ותקול פי 1210 סוי ואחדה פאנהא לא בתלת נקט אלא נקטה ואחדה והי בְמִרכבת המשנה 


\section{II.L.3.2.2.}

Likewise people may ask concerning מֶֶ and why their pointing varies and what is their rule. The response is as follows.

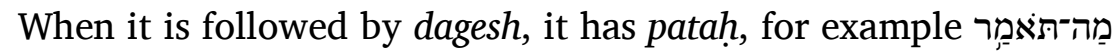

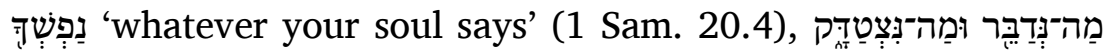
'What shall we speak? And how can we show ourselves to be just?' (Gen. 44.16). When it is followed by rafe, it has segol, for

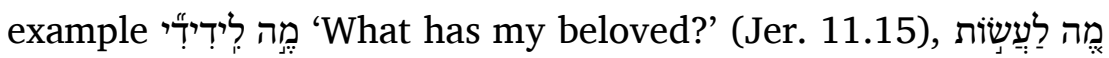
'What is to be done for you? Would you have a word spoken on your behalf?' (2 Kings 4.13), and similar cases.

\section{II.L.3.2.3.}

People may ask concerning לָדמָה what the rule is relating to the fact that it is sometimes with dagesh and sometimes rafe. The response relates to two factors. One is that it is because of the accent, namely when the accent is on the mem of למה, it is rafe and when the accent is on the lamed, it has dagesh, for example

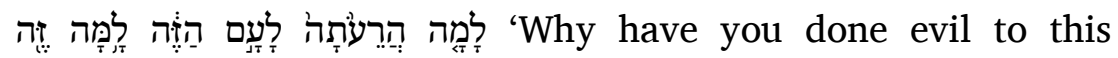
people? Why (did you ever send me)?' (Exod. 5.22). All of the reading of Scripture follows this rule except for one case in Job,

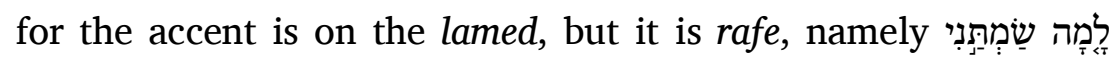

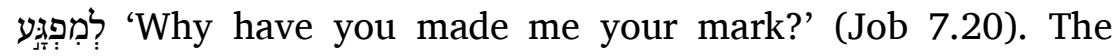
second response is that it is on account of the letter. This rule is superior to the first, since למה may be without an accent but

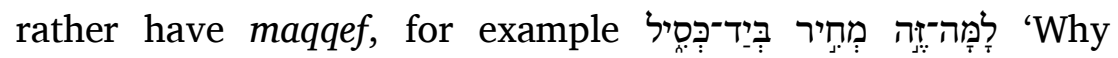
should a fool have a price in his hand' (Prov. 17.16), and similar cases. The rule concerning this is that whenever למה are linked prosodically to three letters, namely 'alef, he and 'ayin, it is rafe,

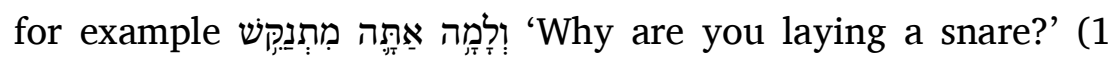

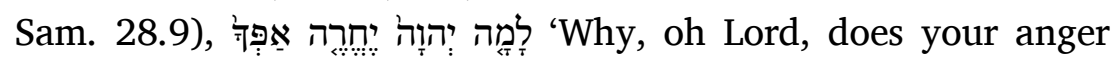


II.L.3.2.2.

וכדלך קד יסל אלנאס ען מַה ומֶה לם יכתלף נקטהמא ומא

שרטהמא אלגואב הו אן אדא >תבעה> דגש כאנת בפאתחה

כָ מַה־תאמר נפשך מַה־נדבֵר ומה־נצטדק ומא תבעה רפי כאן

בסגולה כק מֶה לידידי מֶה לעשות לך היש לדבר לך ומת

II.L.3.2.3.

וקד יסל אלנאס ען לָמָה מא אלשרט פי כונה תארה מדגוש ותארה רפי אלגואב פיה עלי וגהין אלואחד מן אגל אלטעם והו אן אדא כאן אלטעם עלי (L1:36r) אלמאם מן למה כאן רפי ואדא כאן אלטעם עלי אללמאד כאן דגש כק למֵה הרעותָ לעם הזה למה זה וכל אלמקרא עלי הדא אלא ואחד פי איוב פאן אלטעם עלי אללמאד והו רפי והו לָמָה שַמְתַתִי למפ ואלגואב אלذ מן אגל אלחרף והדא אלשרט הו אבלג מן אלאול לאן קד יכון למה בגיר אלטעם בל במקף כק למה זה מחיר ביד כסיל ומת ואלשרט פי דלך הו אן כלמא אסתנד למה אלי תלת חרוף והן

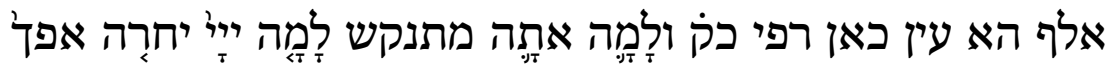




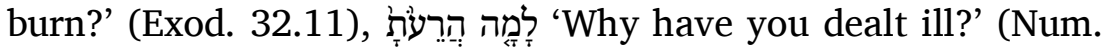

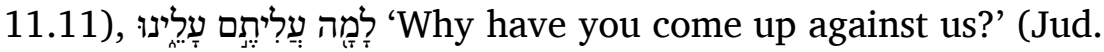
15.10), and the like. There are five cases that are exceptions to this rule, since they are linked prosodically to

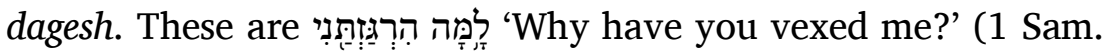

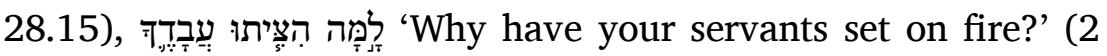

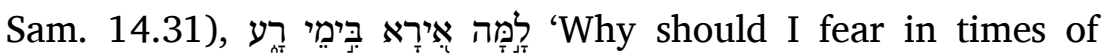

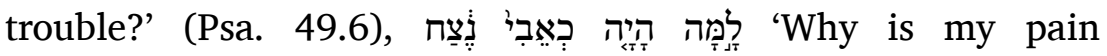

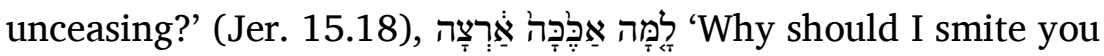
to the ground?' (2 Sam. 2.22). Their mnemonic combination is 'The slave has vexed me; I have feared pain; I have killed him'. If you like, you may say 'The servant has vexed me; I have feared illness; I have smitten him.' Every למה that is prosodically bound to the other letters of the inventory, namely

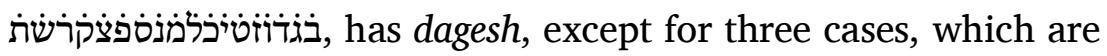

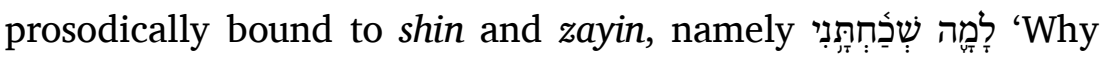

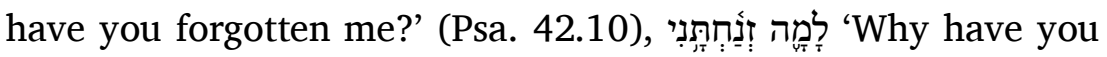

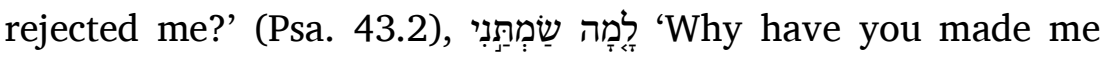
(your mark)?' (Job 7.20). Their mnemonic combination is: 'You made me forgotten and rejected'.

\section{II.L.3.2.4.}

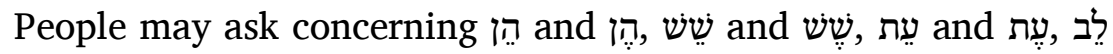

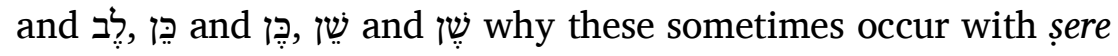
and sometimes with segol. The response concerning this is as follows. When the accent is on the first letter of the word following these words, they have segol so long as they have maqqef, for example הֶֶ־תוּ 'Here is my signature' (Job 31.35), הֶ־־הוּא 'Behold it (is the joy of his way)' (Job 8.19). You say 
למֶה הרעוֹת למה עליתם עלינו ומת ואלדי כרג ען דלך כמסה מואצע פאנהא מסתנדה אלי אהن והי מדגושה והי לפה הרגזתַני למה הציתו עבדיך למה אירא בימי רע למה היה כאבי נצח למה אככה ארצה ורבאטהא אקלקני אלעבד כשית אלוגע קתלתה ואן ארדת תקול >הרגיזני> העבד ייראתי החולי הכיתיו וכל למה אסתנד אלי חרוף אלקבאלה אלאכר הם ב̇גדוֹוֹטיכיכ

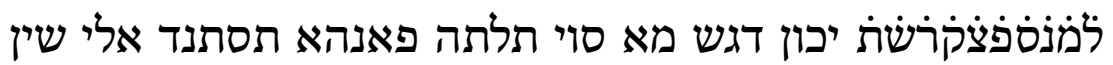
וזאי והן למה שכחתני למה זנחתני למה שמתני ורבאטהא

II.L.3.2.4.

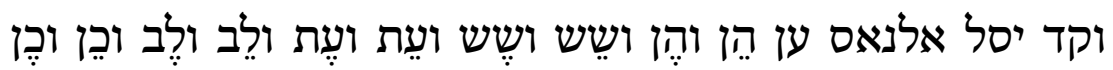

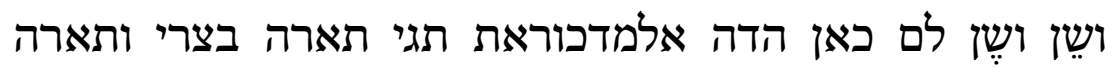

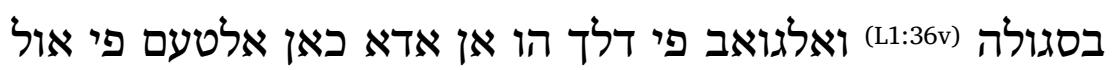
חרף מן אלכלמה אלתאניה להדה אלכלם צארת בסגולה מהמא

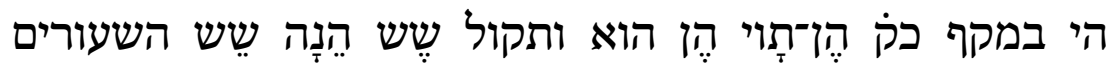

1231 הרגיזני[ [2:2r הרגיני 1232 אסתנד....אלאכר] אסתנד אלי בקיה חרוף אלקבאלה L2:2r 


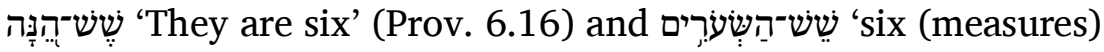

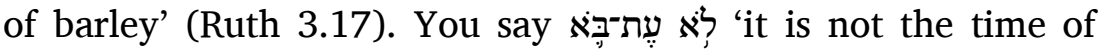

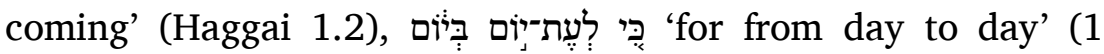
Chron. 12.23). An exception to the (expected form) עִּל בִּא

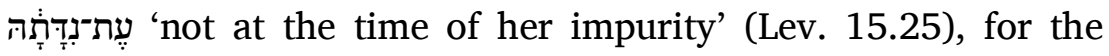
accent is not on the first letter but it has segol. You say

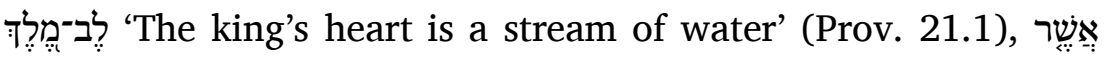

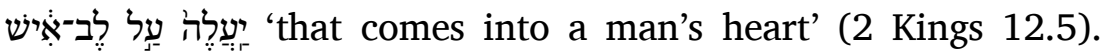

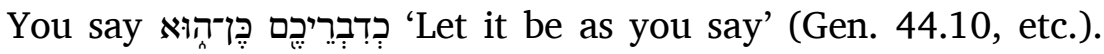

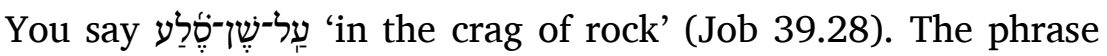

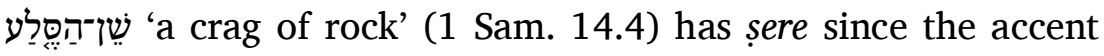
occurs on the second letter.

\section{II.L.3.2.5.}

People may ask concerning אֶ w wת which of them has the accent and which has maqqef. The response is as follows. They say that every without an accent and has maqqef, except for three cases,

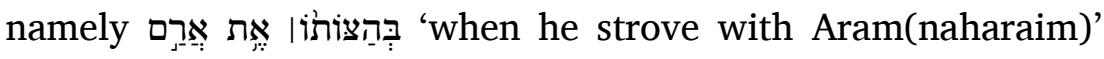

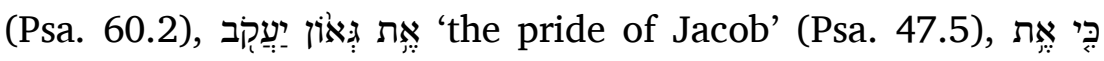

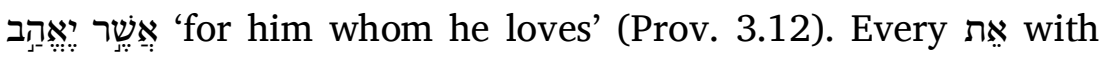
sere must have an accent and never has maqqef, except for one

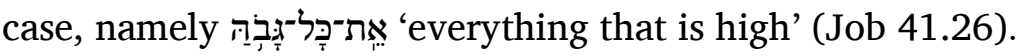

\section{II.L.3.2.6.}

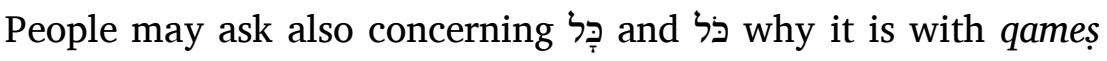
and with holem. The response is as follows. They have said that whenever it has maqqef it occurs only with qames, except for 
ותקול לא עֶת בא כי לעֶת >יום> ביום ואלדי יכרג ען >עת> ק בלא עֶת נדתה פאן אלטעם ליס הו עלי אול חרף וקד גא בתלת נקט ותקול פלגי מים לֶב מלך אשר יעלה על לֶב איש ותקול כדבריכם כֶן הוא ותקול על שֶן סלע שֶן הסֶלע צאר בצירי למא צאר אלטעם מע אלחרף אלתאני

II.L.3.2.5. וקד יסל אלנאס ען אֵת וֶַת מא מנהא בטעם ומא מנהא במקף אלגואב קאלו אן כל אֶת פי אלמקרא בסגולה לא יכון פיהא טעם אלבתה בל במקף אלא ג והי בהצותו אֶת ארם אֶת גאון יע כי אֶת אשר יאהב וכל אֵת בצרי לא בד לה מן טעם ולא ידכלה מקף בתה אלא וא והו אָת־כל גבוה

II.L.3.2.6. וקד יסל אלנאס איצא ען כָל וכל לם כאן בקאמצה ובחלם אלגואב קאלו אן כל מא כאן במקף לא יכון >אלא> מקמוצא

1241 יום] יום יום 1252 | 121 (עת][ 


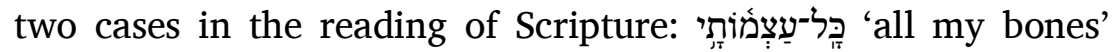

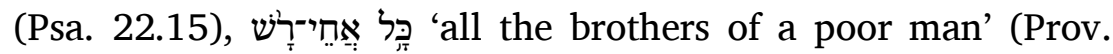

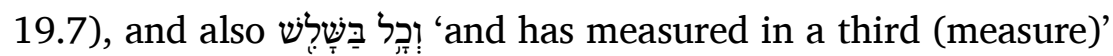
(Isa. 40.12), although they interpreted it as being from the lexical class of 'measuring'. Whenever it occurs with holem, it does not have maqqef but rather has an accent, for example כִּל

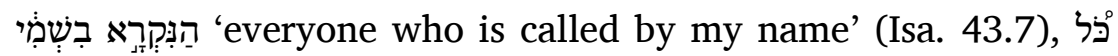

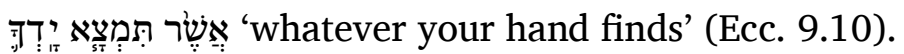

\section{II.L.3.2.7.}

They may also ask concerning the lexical class of 'blessing' why the shewa under the resh is sometimes quiescent and sometimes mobile. The response is as follows. They have said that whenever the accent is under the bet of the lexical class of 'blessing', the shewa is quiescent, for example אֶלה 'Bless the Lord your God' (1 Chron. 29.20). When the

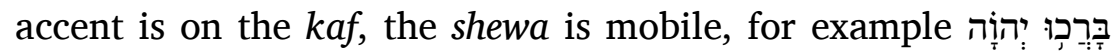

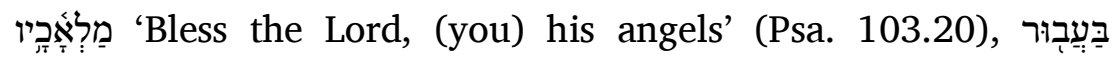

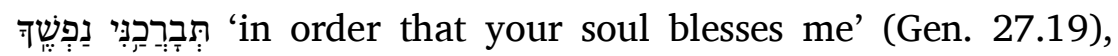
except one case, in which the accent is on the kaf but the shewa

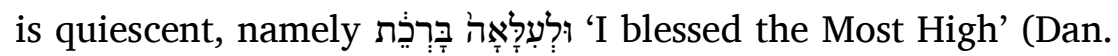
4.31). It may be said that this last case has broken the rule since it is in the Aramaic language. If, however, there is a case that

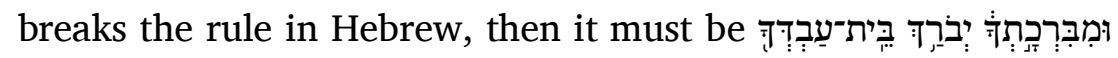
'with your blessing will the house of your servant be blessed' (2 Sam. 7.29), because the accent in this is on the kaf and the shewa is silent, unless it be said that in this word there are two accents. The most plausible statement is that it is a case that

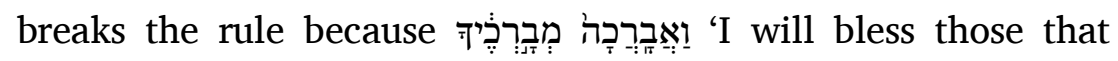
bless you' (Gen. 12.3) has two accents and the shewa is mobile.

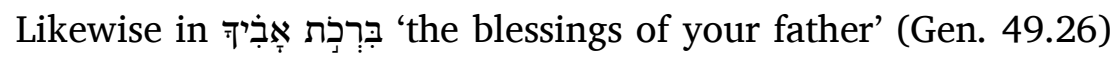
the accent is on the kaf and the shewa is quiescent, and this is also a case that breaks the rule. 
מא סוי תנתין פי אלמקרא כָּל־עצמותי כָּל אחי רש וכָל בשליש ואן כאן יפסרוהא מן אלמכיאל וכל מא כאן בחלם (L1:37r) לא ידכלה מקף בל יכון בטעם כק כל הנקרא בשמי כל אשר תמצֶא

II.L.3.2.7 ויסל איצא ען לשון בְרָכָה לם כאן אלשוא אלדי תחת אלריש תארה סאכן ותארה מתחרך ואלגואב קאלו אן כלמא אלטעם תחת אלבא מן לשון ברכה כאן אלשוא סאכן כק זבּרְכוּ נָא את ייי אלהיכם ואדא כאן אלטעם עלי אלכאף כאן אלשוא מתחרך כק ברכו יִיי מלאכיו בעבור תברכָני נפשך אלא ואחדה פאן אלטעם עלי אלכאף ואלשוא סאכן והי ולעִלָאָה בָרכֵת וקד ימכן אן יקאל אנהא אנמא כסרת אלשרט לכונהא מן לגה אלכסדאני זיר

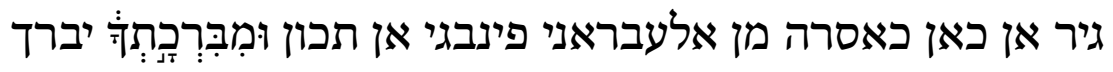
בית עבדך לאן אלטעם פיהא עלי אלכאף ואלשוא סאכן אלא אן יקאל אן פי הדה אלכלמה טעמין ואלקריב אנהא כאסרה לאן ואברכה מבְרכֶיך פיהא טעמין ואלשוא מתחרך וכדלך ברכָות אביך אלטעם עלי אלכאף ואלשוא סאכן פתכון איצא כאסרה עלי אלשרט 


\title{
HIDĀYAT AL-QĀRI' (SHORT VERSION)
}

\author{
II.S.0.0. (INTRODUCTION)
}

GAP

\section{II.S.0.1.}

This is the book of the abbreviated version of The Guide for the Reader, known as The Book of Essential Requirements. ${ }^{1}$

\section{II.S.0.2.}

Its author begins and says: You, may God support you, asked me to abbreviate for you The Book of Rules, which is generally known as The Guide for the Reader, in which I mention its essential requirements. So, I am here responding to this request of yours, asking God to grant me success in this, possibly including where necessary what was not mentioned in The Guide for the Reader. From Him, may He be exalted, I seek help.

\section{II.S.0.3.}

If somebody were to ask what the need is for knowledge of the rules of biblical recitation, the response should be: because the

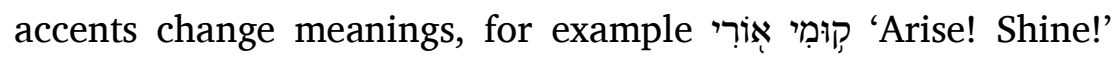
(Isa. 60.1), which are two feminine singular imperatives, since the accent is on the first letter, but לִיזוֹם קוּמִי לְֵָׁר 'for the day

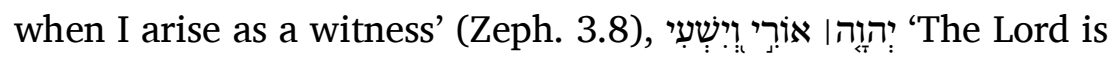
my light and my salvation' (Psa. 27.1), which are two masculine nouns, since the accent is at the end and not the beginning of

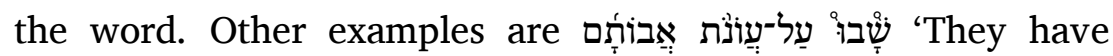
turned back to the iniquities of their forefathers' (Jer. 11.10), which denotes 'returning' since the accent is on the first letter,

\footnotetext{
${ }^{1}$ Literally: the book of the lifeblood.
} 


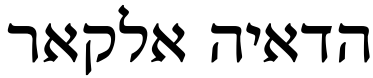

II.S.0.0.

GAP

II.S.0.1.

(S20:1r)

אלמהגה - - - - n

II.S.0.2.

אבתדי מצנפה וקאל סאלתם איידכם אללה אן אכתצר לכם כתאב אלשרוט אלמלקב בהדאיה אלקאר בחית אדכר מוהגה 5 והא אנא מגיב לכם אלי דלך סאילא ללה תופיקי פיה מע מא עסאה אן ינצאף אליה ממא לם ידכר פי הדאיה אלקאר ובה תע אסתעין

II.S.0.3. אן קאל קאיל מא אלחאגה אלי עלם אלשרוט פי אלמקרא קיל לה לאן אלחאן מגיירה ללמעאני מתל קֶוּמִי אָוֹרִי אמרין למונת מן חית אן אלטעם עלי אול חרף מתל ליום קומי לעד ייי אורי

וישעי אסמין למדכר למא תאכר אללחן ען אול אלכלמה (S9:1r) ומתל שבו על עונות אבותם מן אלרגוע לאן אלטעם עלי אול 


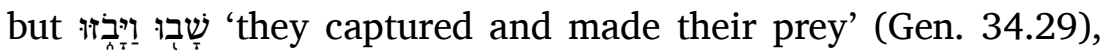
which denotes 'capturing' since the accent is placed not on the beginning of the word but on its end.

\section{II.S.0.4.}

A further reason is that this reading, which is now current in the Land of Israel, is the reading of Ezra, peace be upon him, and his generation, because the nation was not cut off from the Land of Israel from the time of Ezra, peace be upon him, in the Second Temple, until now, except from Jerusalem during the reign of Edom over the land. Israel taught this reading to their children until now, generation after generation. Another reason is that if somebody were to read the twenty-one books with the accents of the three books or the three books with the accents of the twenty-one books, this would be rejected. Likewise, if somebody read merkha in place of darga or darga in place of merkha, the congregation would declare him to be in error in this regard.

\section{II.S.0.5.}

So, if there are rules for the accents, there is a need to know them. 
חרף שבו ויבוזו מן אלסבי לתאכר אללחן ען אול כלמה אלי

\section{אכרהא}

II.S.0.4.

ולאן הדה אלקראה אלדי פי ארץ ישראל אלאן הי קראה עזרא

עה וגילה לאן מא אנקטעת אלאמה מן ארץ ישראל מן זמאן עזרא עה פי בית שני אלי אלאן אלא מן ירושלם פקט פי זמאן מלך אדום ללארץ וישראל יעלמון אולאדהם אלי אלאן גיל בעד גיל הדה אלקראה ולאן לו קרא אלאנסאן אלכא ספר בלחן אלג 20 אספאר או אלג אספאר בלחן אלכא ספר לרד דלך עליה וכדא לו קרא מוצע סלסלה מארכה או מוצע מארכה סלסלה לגלטה אלגמע פי דלך עלמהא ואדא כאן ללאלחאן שרוט פקד דעת אלחאגה אלא 


\section{II.S.1.0.}

\section{SECTION CONCERNING THE PLACE OF ARTICULATION OF THE LETTERS}

\section{II.S.1.1.}

The letters consist of twenty-two basic letters. They fall into five

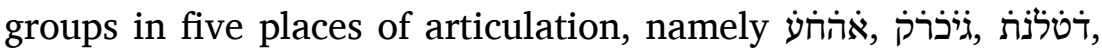

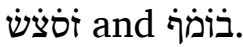

\section{II.S.1.2.}

Take note that the place of articulation of غنتخن is the root of the tongue and the place of swallowing, that is the throat and the base of the tongue. For this reason they are the lightest of the letters and never take dagesh. It may be thought that he and 'alef take dagesh, but this is not the case. This is because the dot in the he at the end of a word indicates the (consonantal) property of the he. Surely you see that the property of the he at the beginning and in the middle of a word appears without a dot. As for (the dot in) 'alef in the four places (where it is found),

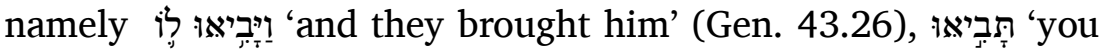

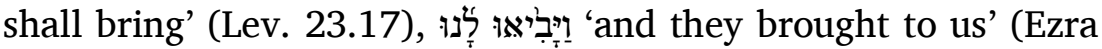
8.18), לִאט רִאוּו 'were not seen' (Job 33.21), this reflects a strong effort to pronounce the letter by the reader and is not dagesh. 


\section{II.S.1.0. \\ פצל פי מחל אלחרוף}

II.S.1.1.

אלחרוף ذذ חרפא אצולא (S20:2r) תגי כמס אקסאם פי כמסה

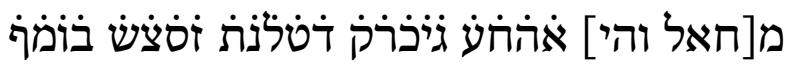

אעלם אן אהחע מחלהא עיקר הלשון ובית הבליעה והו אלחלקום ואצל אללסאן ולדלך כאנת אכף אלחרוף לא ידכלהא דגש בתה ואלהי ואלאלף קד יוצן אן ידכלהא דגש וליס אלחאל כדלך לאן אלנקטה פי אלהי פי אכר אלכלאם תטהר טעם אלהי אלי תרי אן טעם אלהי פי אול אלכלאם ופי וסטה יטהר מן דון אלנקטה ואלאלף פי אלארבעה מואצע אלתי הי ויביאו לו תביאו ויביאו לנו לא ראו פהו תכלף יתכלפה אלקאר פי כרוגה שדידא פליס הדא דגש

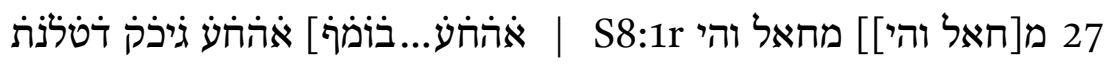

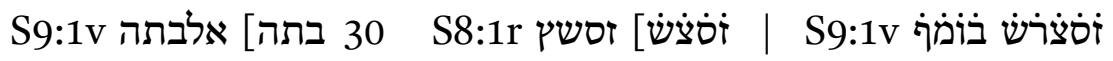

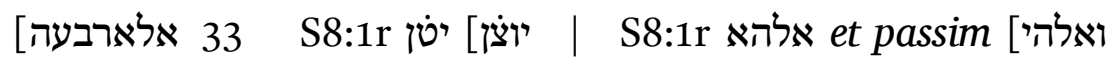
ארבע S8:1r 


\section{II.S.1.3.}

The place of articulation of is the middle of the tongue, in its wide part. The place of articulation of $\dot{i}$ pronounced rafe is the third of the tongue adjacent ot the throat.

\section{II.S.1.4.}

The place of articulation of דَن is the extremity of the tongue in combination with the flesh of the teeth. When the letters are pronounced rafe, the extremity of the tongue is pressed gently onto the flesh of the teeth.

\section{II.S.1.5.}

The place of articulation of

\section{II.S.1.6.}

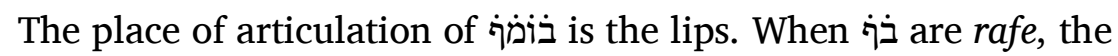
lips are closed gently while they are pronounced.

\section{II.S.1.7.}

It is said that the letters interchange with one another, as in 'he scattered' (Psa. 68.31) and 'he has distributed' (Psa.

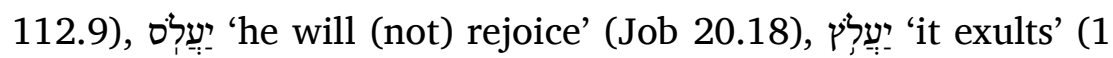
Chron. 16.32), and similar forms. There are cases of enhancement and reduction. It is preferable, however, not to call it 'interchanging', for it is possible that this takes place for a reason, either to express multiplicity or paucity, or for some 
II.S.1.3.

גંֹּרֹק מחלהא וסט אללסאן בערצה ומחל ג̇ך אלמורפיין תלת אללסאן ממא ילי אלחלקום

II.S.1.4. דَטלֹנת מחלהא טרף אל[לסאן ולח]ם אלאסנאן ודת אלמורפיין

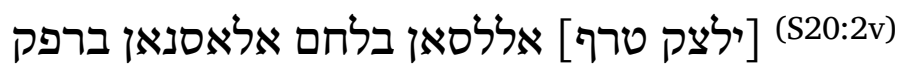

II.S.1.5. זֹסצن מחלהא אלאסנאן

II.S.1.6. בֹֹֹֹף מחלהא אלשפתין ב̇ं אלמרפיין תטבק אלשפתין בהמא ברפק מוֹ מוֹ

II.S.1.7. אלחרוף יקאל אנהא תנבדל בעץ בבעץ מתל בִזָר פִזרר יעלוס

יעלוץ ונחו דלך ותגי זואיד ונואקץ ואלאולא אן לא יקאל דלך לאן ימכן אלתבדיל אדא כאן עלי וגה אמא לכתרה או לקלה או

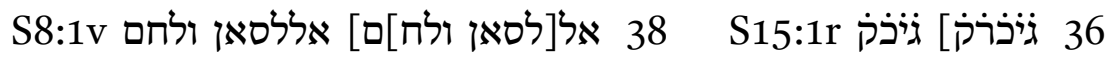
39 S21:1v ואלאולא] אלאולי [ילצי 
other reason. They give the form bet to express one sense and for another sense they give it pe. Likewise with יעֶלו,-, when the joy has a particular sense, they give it samekh and for another sense they give it zayin, and so forth concerning what I initially said were cases of interchange and inversion. 
לוגה מן אלוגוה יגעלוהא בבי ועלי וגה גירה יגעלוהא בפי וכדלך

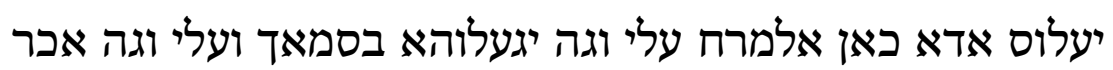

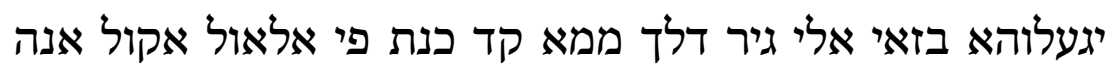
ינבדל וינקלב

46 יגעלוהאי][יגעלוה S21:1v |

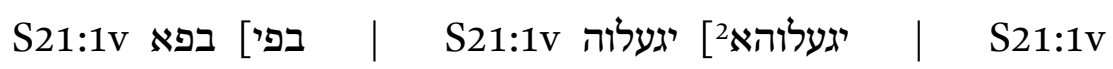
S21:1v יגעלוהא] יגעלוה 47 


\section{II.S.2.0. \\ SECTION CONCERNING אגדَذَפת AND}

\section{II.S.2.1.}

When one of these four letters, I mean word and the word is conjoined to what follows it by a (conjunctive) accent, and when the second word begins with one these six letters, I mean בגדذذפת, this letter is pronounced

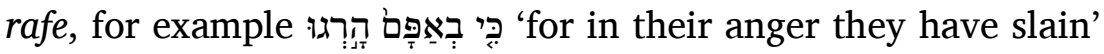

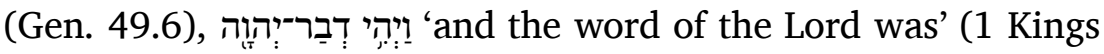

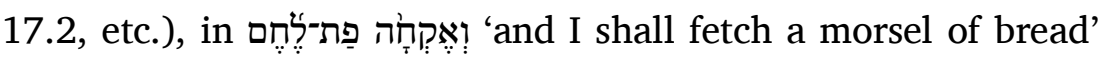
(Gen. 18.5), and similar cases.

\section{II.S.2.2.}

There are nine types of cases that break the rule I have just mentioned. These are 'oghera, di-fsiq, di-dhhiq, 'athe me-rahiq, mappiq he, mappiq vav, mappiq yod, two identical letters, bet and pe.

\section{II.S.2.3.}

As for 'oghera, this is the 'collection' of only seven words. Four of these are in the song Ine (Exod. 14.30, 'the Song of the

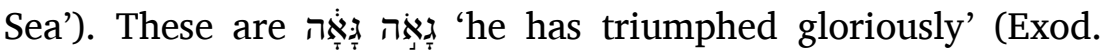

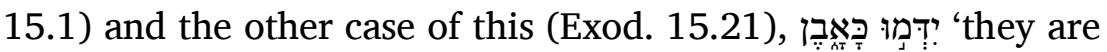

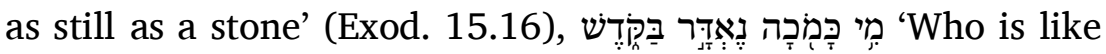
you, majestic in holiness?' (Exod. 15.11). In the book of Isaiah 


\section{II.S.2.0.

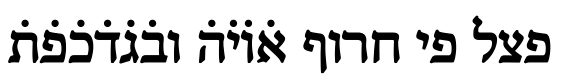

II.S.2.1.

הדה אלארבעה חרוף אעני אוּיָה אדא כאן אחדהא פי אכר כלמה וכאנת אלכלמה מצאפה אלי מא בעדהא באללחן וכאנת אלכלמה אלתאניה אולהא אחד הדה אלסתה חרוף אעני בֹ̇ד ذפ் כרג דלך אלחרף מרפי כפיף כקולה כי באפם (S20:3r) הרגו ויהי דבר ייי ואקחה פת לחם ואמתאל דלך

II.S.2.2. ואלדי כרג ען מא דכרת תסעה כואסר הם אוֹבֵּיָרה ודפסיק ודדחיק וַאַתֵא מרחיק ומפיק הי ומפיק ואו ומפיק יוד וחרפין מתראדפין ובי ופי

II.S.2.3. אוגירה גאמעה לסבעה כלם פקט ארבעה מנהא פי שירה ויושע והי גָאה גאה וחבירו ידמו כָאָבן מי כמוכה נאדר בקדש ופי ספר

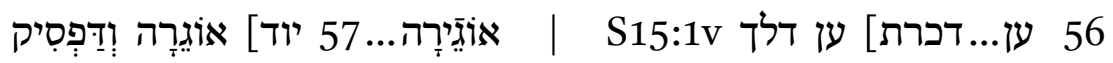

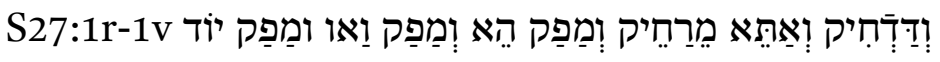




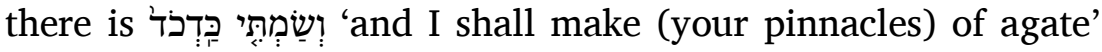

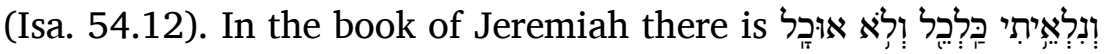
'and I am weary of holding it in and I cannot' (Jer. 20.9). In the

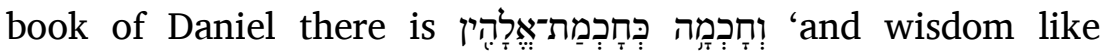
wisdom of the gods' (Dan. 5.11). I do not know any disagreements concerning these seven. In other cases, concerning which there are disagreements, the reader should choose which of the variants he wants to read in his reading and nobody can reject this.

\section{II.S.2.4.}

As for di-fsiq, whenever paseq comes between one of the letters

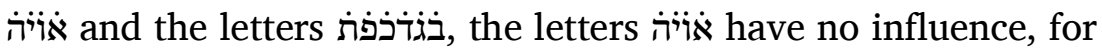

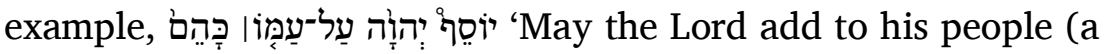

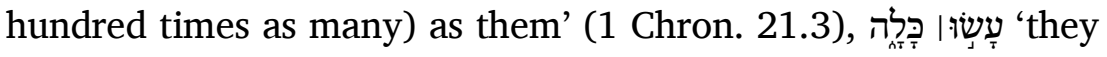
have done completely' (Gen. 18.21), and similar cases. There is no exception to this type of case that breaks the rule.

\section{II.S.2.5.}

Di-dhhiq: The meaning of di-dhhiq (literally: what is compressed) is that between the accent that is in the word containing one of

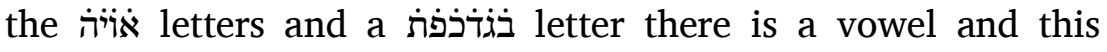
vowel is not dwelt upon or prolonged in pronunciation. On account of this compressed vowel the rule of the

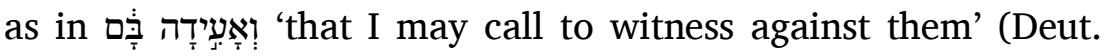

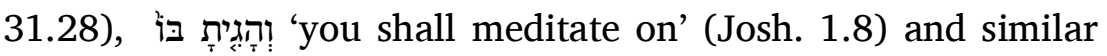
cases. The compression may occur in a word that does not have 
ישעיה ושמתי כדכד ופי ספר ירמיה ונלאתי כלכל ולא ופי ספר דניאל וחכמה כחכמת אלהין ומא ערפת פי הולי אלסבעה כלף ומא עדאהם מן אלכלף אלקאר מכיר פי אלקראה מא אראד מן אלאכלאף יקרא וליס לאחד אן ירד עליה

II.S.2.4. 65 דפסיק כל מא חצל בין חרף אלאוּיה ובין חרף ذ̇גד ذפּ פסיק לא יכון ללאוֹיוּה תאתירא מתל יוסף ייי על עמו כהם עשו כלה יו יו ואמתאל דלך וליס עלי הדה אלכאסרה אסתתנא

II.S.2.5. דדחיק מעני דדחיק הו אן יכון בין אללחן אלדי פי אל (S20:3v) כלמה אלדי פיהא חרף אלغוּיה ובין חרף ذגד ذפות מלך ואחד 70 ולא יתאנא ולא יטול פי אלנטק בדלך אלמלך פלאגל הדא

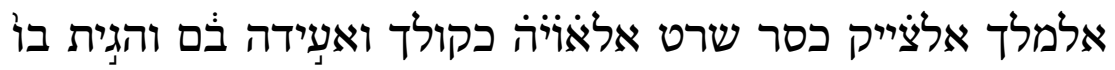
ואמתאל דלך וקד יכון >אלציק> חאצל פי כלמה ליס פיהא

61 ושמתי] וסמתי S15:1v 62 הולי] האולאי S15:1v 63 אלקראה] קראתה S15:1v 68 אלדי] אלתי S15:2r 71 אלילי] הלייק] הדא אליציק S15:2r ואמתאל דלך] ומא מאתל האולאי S15:2r S29:1r אלציק] S4:1v אלצייק S20 


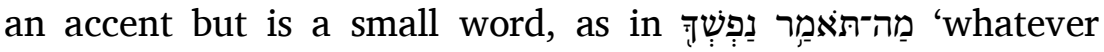

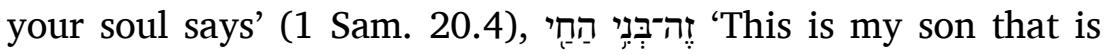
alive' (1 Kings 3.23), and other similar cases in which the vowel is pronounced compressed. Surely you see in 'through which you let us down' (Josh. 2.18), in which the vowel after the accent is pronounced long with exhalation of breath, the same, or approximately the same, as other (long) vowels, the bet of i does not have dagesh. If you examine this closely, you will discern the difference.

\section{II.S.2.6.}

'Athe me-rahiq is the opposite of the previous type of case that breaks the rule, because this one (i.e. 'athe me-rahiq) is on account of what is far and that one (i.e. di-dhhiq) is on account of what is near. This (i.e. 'athe me-rahiq) arises from the fact that due to the distance of the accent (from the preceding conjunctive accent), one comes upon it (the accent) like a ballista and so

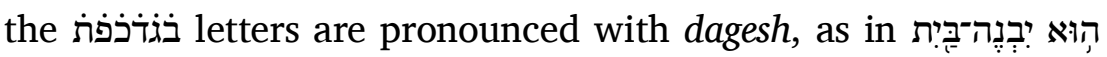

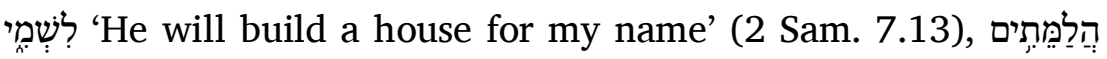
'Do you work wonders for the dead?' (Psa. 88.11),

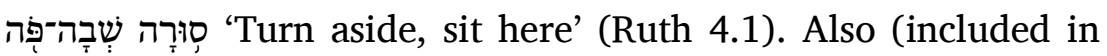
this category) are cases in which there is no (conjunctive) accent, so (such cases must be considered) to have a virtual (conjunctive) accent before them in order to conform to (cases

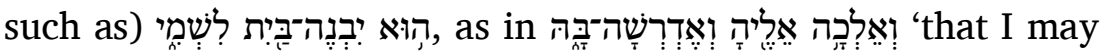
go to her and inquire of her' (1 Sam. 28.7), and similar cases. 
טעם גיר אנהא תכון כלמה צגירה כקולך מה תאמר נפשך זה בני החי ומא מאתלהמא ממא יגי >אלנטק> באלמלך אלצייק 75 אלי תרי אלי קולך אשר הורדתינו בו למא גא פי >אלמלך> אלדי בעד אלטעם תוסע ב>תנפיס> יגרי מגרי מלך אכר או קריב מנה לם יגי אלבי מן >בו> דגש ואדא תאמלת וגדת אלפרק

II.S.2.6. אַתֵא מרחיק באלעכס מן אלכאסרה אלמתקדמה לאן הדה למא 80 בעִד ותיך למא קרֶב והו אן כמא יבעד אללחן ינצב עליה כאלמנגניק פידגש >חרוף> ذَגד ذפֹ כק הוא יבנה בית הלמתים תעשה פלא סורה שבה פה ומא לם יכון פיה לחן פהו (S20:4r) בתקדיר לחן קבלה ליגרי מגרי הוא יבנה בית כקוֹ ואלכה אליה ואדרשה בה ומא מאתלהא

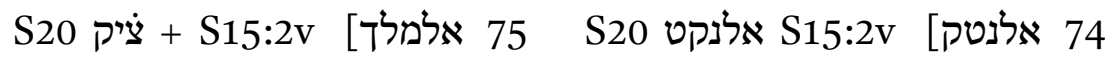

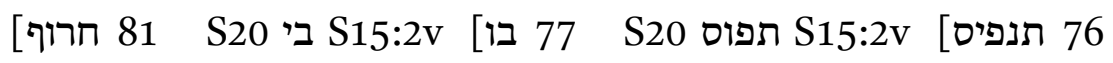
S20 אלצייק S15:2v 


\section{II.S.2.7.}

So far four types of cases that break the rule have been discussed. The fifth type of case that breaks the rule is mappiq he. The meaning of the term mappiq he is the (consonantal) pronunciation of the he and its appearance. It is derived from

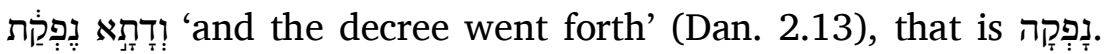
This is because when the he is pronounced at the end of a word,

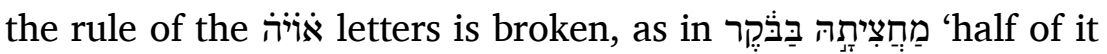

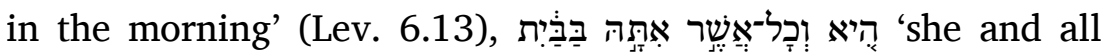

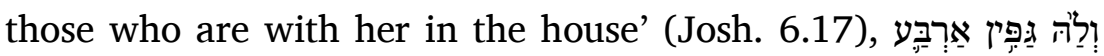
'and it has four wings' (Dan. 7.6), and similar cases. There are no exceptions to this breaking of the rule at all.

\section{II.S.2.8.}

The sixth type of case that breaks the rule is mappiq vav. This is because every vav at the end of a word is pronounced according to the view of the Palestinians as a bet rafe, which breaks the

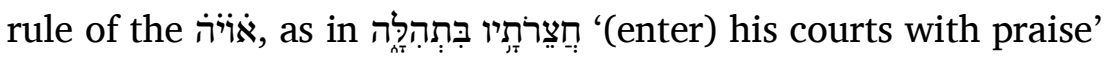

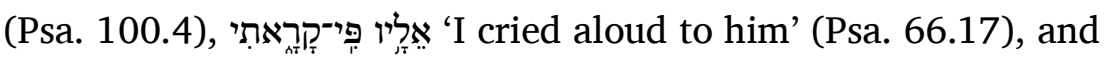
similar cases. There are only two words that are exceptions to

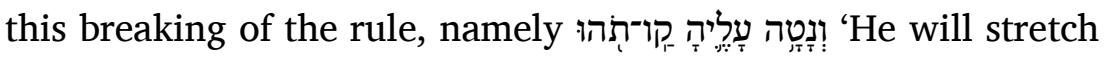

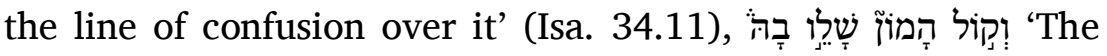
sound of a carefree multitude was with her' (Ezek. 23.42).

\section{II.S.2.9.}

The seventh type of case that breaks the rule is mappiq yod. This is that whenever yod occurs at the end of a word and the next word begins with one of the בגنَذפت letters, and hireq or șere, I mean a dot or two dots, occur under the letter before the yod,

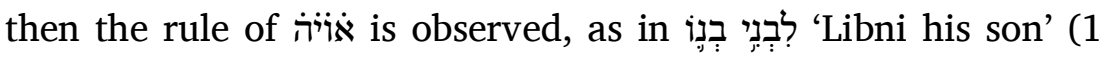

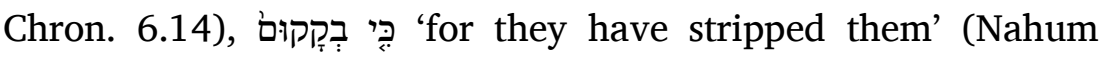

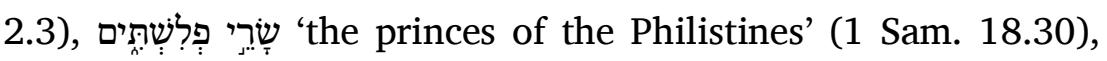


II.S.2.7.

85 אלאן קד מצא ארבעה כואסר אלכאסרה אלכאמסה מפיק הי מעני מפיק הי הו כרוג אלהי וטטהורהא ואשתקאקהא מן דָתָה נִפְקַת נפקה והו אן אלהי אדא טהר פי אכר אלכלמה כסר שרט אלאוֹיוּה כק מחציתה בבקר היא וכל אשר אתה בבית ולה גפין ארבע ומא מאתל דלך ומא עלי הדה אלכאסרה שי מן אלמסתתנא בתה

II.S.2.8. אלכאסרה אלסאדסה מפיק ואו ודאך אן כל ואו פי אכר כלמה יכרג עלי ראי אלשאמיין בבי מרפי יכסר עלי שרט אלאוֹיה כקולך חצרותיו בתהלה אליו פי קראתי ואמתאלהמא ואלדי יסתתנא עליה הדה אלכאסרה לפצתין פקט המא ונטה עליה קו

II.S.2.9. אלכאסרה אלסאבעה מפיק יוד והו אן כל יוד יכון פי אכר כלמה ואול אלאכר חרף מן חרוף ذ̇ंד ذפֹ ותחת אלחרף אלדי קבל אליוד חרק או צרי אעני נקטה או (S20:4v) נקטתין פאן שרט

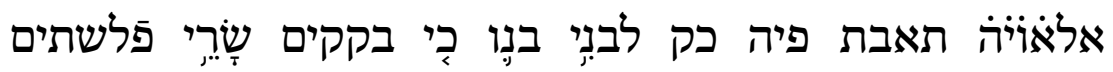


and similar cases. If vowels that are different from the aforementioned occur under the aforementioned letter, the yod is strengthened and the rule of אוּרֵי

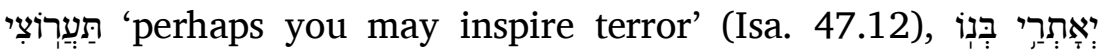

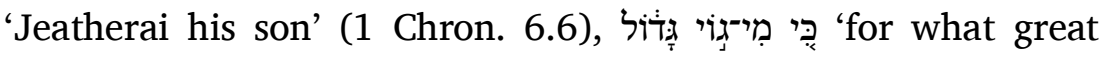
nation' (Deut. 4.7), and similar cases. One word is an exception to this breaking of the rule.

\section{II.S.2.10.}

The eighth type of case that breaks the rule is the succession of two letters. If two bets or kafs, but not the remaining letters, I mean בגדiذפת, succeed one another and under the first of them there is a shewa, then the rule of ili

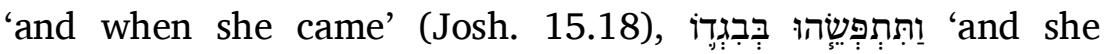

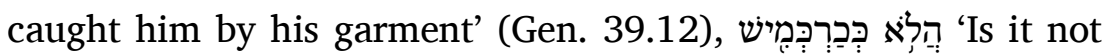
like Carchemish?' (Isa. 10.9), and other cases. If a vowel occurs under the first of the two instead of shewa, the rule of

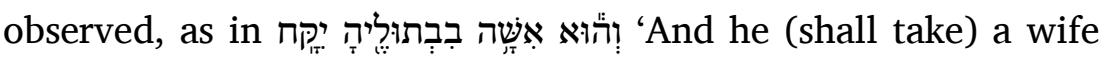

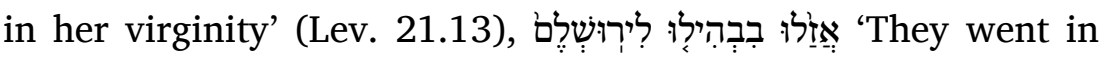
haste to the Jews' (Ezra 4.23), and similar cases.

\section{II.S.2.11.}

The ninth type of case that breaks the rule is bet and pe. The statement concerning them is similar to the statement regarding the preceding type of case that breaks the rule, without there being any disagreement. This is that when bet is followed by pe and shewa is below the bet, the rule of is broken, as in

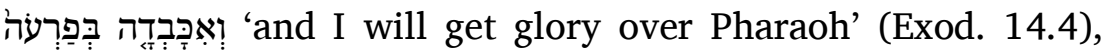

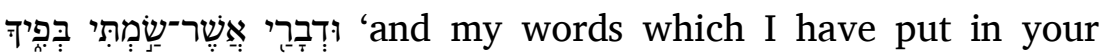
mouth' (Isa. 59.21), and similar cases. If a vowel occurs instead of shewa, then the rule of is observed, as in נִהְרִ 'He will not look upon the rivers, the streams' (Job 20.17). 
100 אלמדכורין אשתד אליוד ולם יתבת שרט אלאוֹיה כקו אולי תערוצי יאתרי בנו ומי גוי גדול ואמתאל דלך ויסתתני עלי דלך בלפצה ואחדה

II.S.2.10. אלכאסרה אלתאמנה חרפין מתראדפין כל בֵֵַין או כאפין תראדפא אלואחד בעד אלאכר מן דון בקיה אלחרוף אעני בגד ذפֹ וכאן תחת אלאול מנהמא שוא כסר שרט אלאוֹיה מתל ויהי בבואה ותתפשיהו בבגדו והלא ככרכמיש אלי גיר דלך פאן כאן תחת אלאול מנהמא עוץ אלשוא מלך תבת שרט אלאוּיה כקו והוא אשה בבתוליה יקח אזלו בבהילו לירושלם ואמתאלהמא

II.S.2.11. אלכאסרה אלתאסעה בי ופי אלכלאם פיהא כאלכלאם פי אלכאסרה אלתי קבלהא מן גיר כלף והו אן כל בי ובעדה פי אדא כאן תחת אלבי שוא כסר שרט אלאויنה כקוֹ ואכבדה בפרעה אשר שמתי (S20:5r) בפיך ומא מאתלהמא פאן צאר עוץ אלשוא מלך תבת שרט אלאוֹויה כקוֹ אל ירא בפלגות נהרי 


\section{II.S.2.12.}

Take note that seven cases of kaf after וְיְ are the subject of disagreement, some pronounce them with dagesh and others

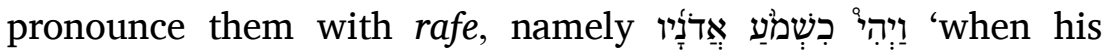

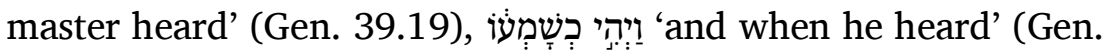

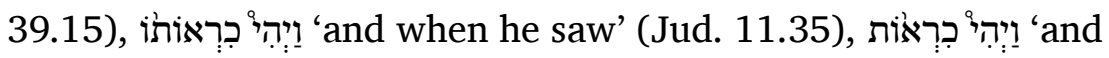

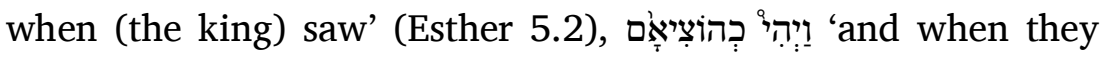

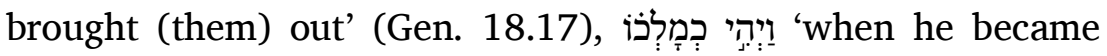

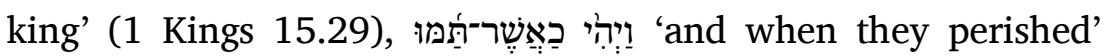
(Deut. 2.16). ${ }^{2}$ The reader makes a choice: if he wants, he strengthens them (with dagesh), and if he wants, he pronounces them with rafe.

\section{II.S.2.13.}

Take note that the criterion of the (rule of) the liisters and the letters should be based on pronunciation and not on

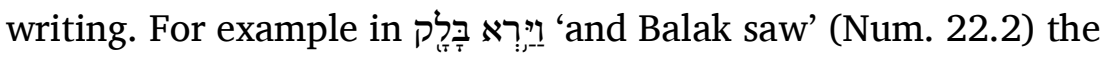
bet is pronounced with dagesh, because the last letter heard

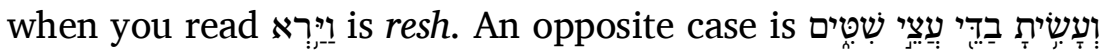
'and you will make poles of acacia wood' (Exod. 25.23). The last letter heard when you read the word ועָָשָׁית is 'alef or he, and therefore the bet of בַָָ is pronounced rafe. This is the principle throughout the reading of Scripture.

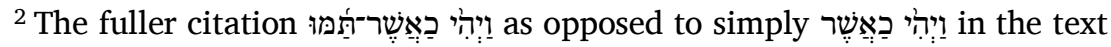
of Hidāyat al-Qāri’ is given in Kitāb al-Khilaf (ed. Lipschütz, 1965, 19).
} 
II.S.2.12.

ואעלם אן סבעה כאפאת בעד ויהי הי כלף בעץ ידגשהא ובעץ

ירפיהא והי כשמוע כשמעו כראותו כראות כהוציאם כמלכו

כאשר אלקאר מכייר אן >שא> ישד ואן שא ירפי

II.S.2.13.

ואעלם אן אלמעול פי אלאוֹיنה ובֹגד ذפת עלי אללפט לא עלי

120

פי וירא אלריש ובעכסה ועשית בדי עצי אכר חרף סמע מנך פי

ועשית אמא אלף ואמא הי פלדלך גא אלבי מרפי מן בَדי ועלי

הדה אלסירה תסיר פי אלמקרא כלה 


\section{II.S.3.0.}

\section{(TAV)}

Take note that tav in three places is strengthened with dagesh to a greater degree than (other) cases of tav with dagesh. These are 'He made it an eternal heap of ruins' (Josh.

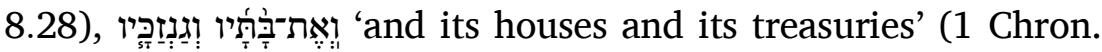

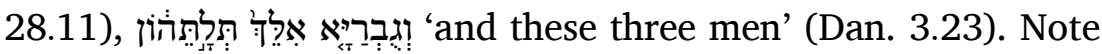

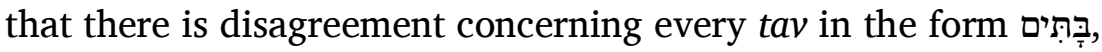
except in (1 Chron. 28.11). Whoever wishes to pronounce it with the normal dagesh of tav, may do so and whoever wishes to pronounce it with the heaviness of the tav of וֹאֶת (1 Chron. 28.11), may do so, on condition that this is when there is a conjunctive accent and a disjunctive accent in the word without an intervening letter. 


\section{II.S.3.0.}

ואעלם אן אלתיו ידגש פי תלתה ומואצע זאידא ען סאיר 125 אלתֵוַאת מדגושה והי וישימיה תל עולם שממה ובُתיו וגנזכיו וגבריא אלך תלתהון ואעלם אן כל תיו פי לשון בתים מא סוא ובתיו וגנזכיו הו כלף ומן אראד אן יכרגה בדגש אלתיו אלמעהוד אכרגה ומן אראד יכרגה >בתקל> (S20:5v) תיו ובתיו אכרגה בשרט אנה אדא כאן פי אללפטה כאדם ולחן וליס בינהמא חרף 127 אן] 127 S25:2r omitted בתקל] S25:2r 128 S20 


\section{II.S.4.0.}

\section{SECTION CONCERNING THE VOWELS}

\section{II.S.4.1.}

What is to be said concerning the vowels is manifest and clear, and not obscure, because it is through them that the purpose of a speaker is understood, and without them speech would be nonsense. A letter can be without a vowel, but a vowel cannot be without a letter.

\section{II.S.4.2.}

The total number of vowels is seven: within these seven vowels the letters $\boldsymbol{N}, \mathbf{n}$, l, and , are pronounced. From qames, patah and segol $^{3}$ 'alef and he are

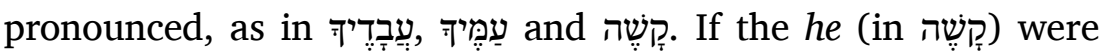
elided, the segol (by itself) would indicate its existence, just as

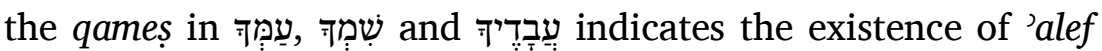

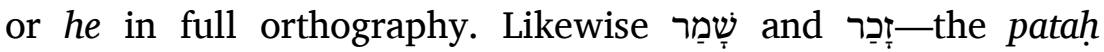
indicates the existence of 'alef. Holem ${ }^{4}$ indicates the existence of

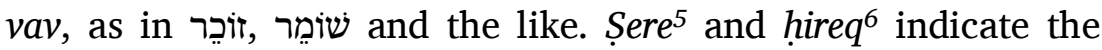
existence of yod, as in עיני, since the yod is frequently written defectively but these two vowels indicate its existence.

\footnotetext{
${ }^{3}$ Literally: the three (points). | ${ }^{4}$ Literally: the point above. $\mid{ }^{5}$ Literally: the two points. | ${ }^{6}$ Literally: the point below.
} 


\section{II.S.4.0. \\ (S8:2v)}

II.S.4.1. אלכלאם פי אלמלוך טאהר גִלִי גִיר כפי לאן בהא יפהם ען אלמתכלם גרنה ולולאהא לכאן אלכלאם עבתא (S15:3r) פחרף קד יכון בגיר מלך ומלך לא יכון בגיר חרף

II.S.4.2.

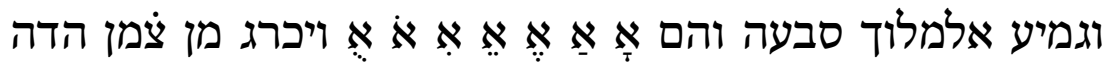

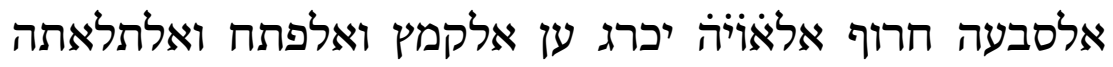

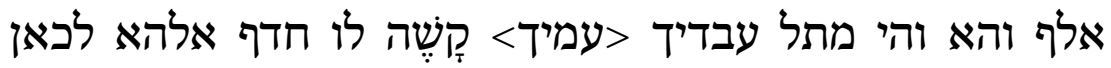

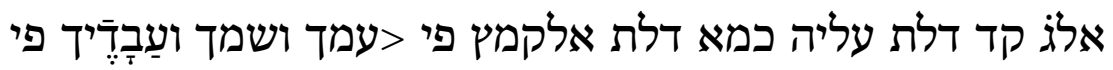

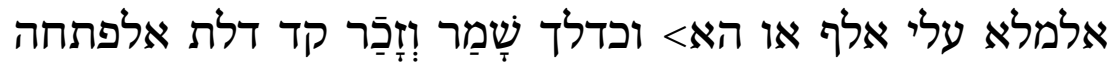

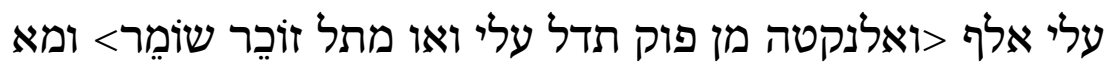

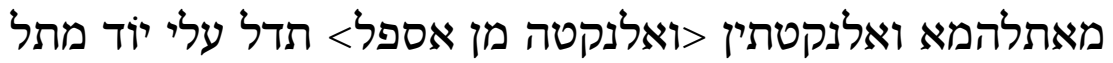

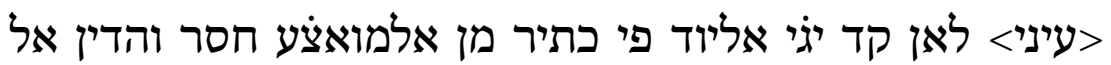

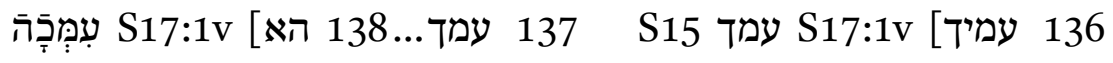

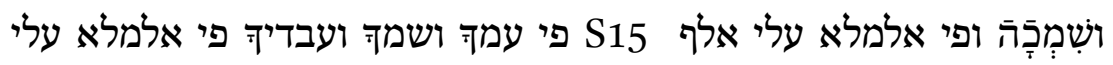

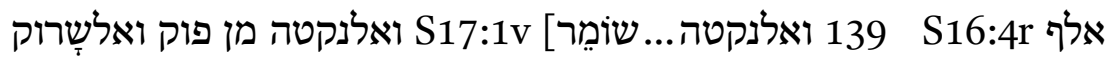

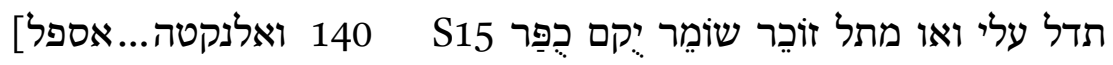

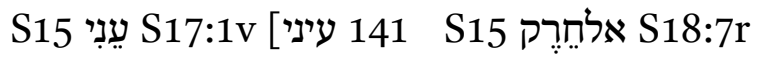


Qibbus ${ }^{7}$ and shureq ${ }^{8}$ indicate the existence of $v a v$ as in קוּמו. So what is pronounced from within the seven vowels are the letters $\kappa, \mathrm{N}, \mathrm{l}$, and ?.

${ }^{7}$ Literally: the arrowhead. | ${ }^{8}$ Literally: the point in the heart of the vav. 
(S15:3v)

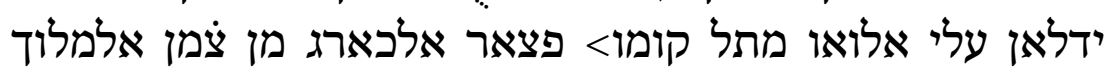
אלסבעה אהוּוּ

142 ואלִזִג... 143 קומו] S15 omitted S18:7r 


\section{II.S.5.0.}

\section{SECTION CONCERNING THE SHEWA}

\section{II.S.5.1.}

The shewa is to be classified into two categories: quiescent and mobile. The distinctive feature of the quiescent shewa is that it makes quiescent the letter under which it is present and puts it in the group (of letters) that precedes it, as in ישָׁרָאל 'Israel',

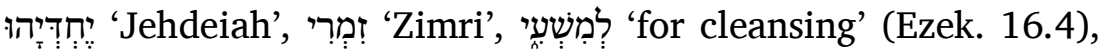

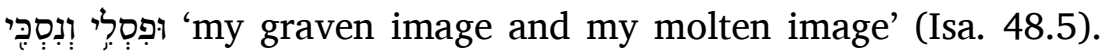
So the letter under which it is present has become quiescent, and has been separated from what follows it and conjoined to what is before it. It is also distinctive of its nature that it divides a word into (units that have) the status of words. This is because every letter at the end of word that is without a vowel and quiescent becomes the stopping point of the word and its place of division, like the tav in בְּרֵאשִׁית 'in the beginning' and like the resh in אisht'. Likewise (a quiescent letter) in the middle (of a word) has the status of a stopping point, as in

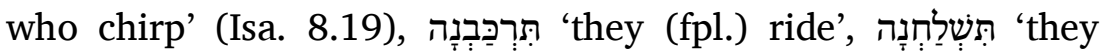
(fpl.) send'. Each one of these words has the status of three words on account of the quiescent shewa. If it were absent, such a division would not be correct.

\section{II.S.5.2.}

The distinctive feature of the mobile (shewa) is that when it is under a letter, the letter is not static or at rest, as, for example,

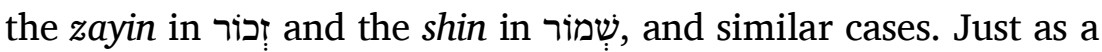
quiescent letter groups with what comes before it, a mobile letter groups with what is after it, the opposite (of what is the 


\section{II.S.5.0. \\ פצל פי אלכלאם עלי אלשוא}

II.S.5.1. אלשוא ינקסם קסמין סאכן ומתחרך עלאמה אלסאכן אנה יסכן

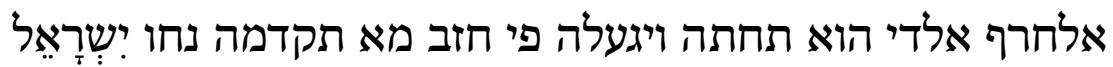
יחדיהו זמרי למשעי ופסלי ונסכי פצאר אלחרף אלדי תחתה סאכנא ואנפצל ממא בעדה ואנטאף אלי מא קבלה ומן עלאמתה איצא אנה יקסם אלכלמה מתאבה כלם לאן כל חרף הו פי אכר כלמה אדא ערי מן מלך כאן סאכן לאנה יציר מחט אלכלמה ומקטעהא נחו אלתאו מן בראשית ונחו אלריש פי אור וכדלך חכמה פי אלוסט יציר מחט עלי וגה המצפצפים תרכבנה תשלחנה צאר (S15:4r) כל כלמה מן האולאי מתאבה ذ כלם לאגל אלשוא אלסאכן ולו אנעדם לם תצח אלקסמה

II.S.5.2. עלאמה אלמתחרך הו אנה אדא כאן תחת חרף לא יסתקר דלך

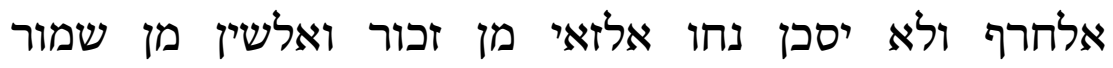

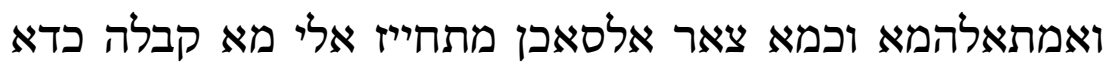
צאר אלמתחרך מתחייז אלי מא בעדה באלעכס מן אלסאכן 


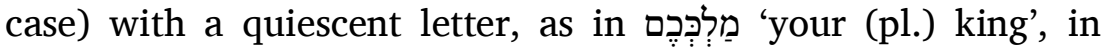
which the lamed is quiescent with a quiescent shewa and groups with the mem, whereas the kaf is mobile with a mobile shewa

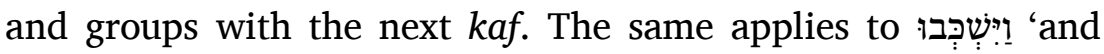
they lay down',

\section{II.S.5.3.}

If there is doubt in some cases as to whether the shewa is quiescent or mobile, the endowing of heaviness to the letter before the letter with the shewa indicates that it is mobile. This a המֶ applies the beginning of words. When shewa is under the mem and patah is under the he and it (i.e. the patah) is made heavy, then the shewa is mobile.

\section{II.S.5.4.}

The mobility of the shewa can also be ascertained by the number of letters of the word. If there are five letters, then the shewa is

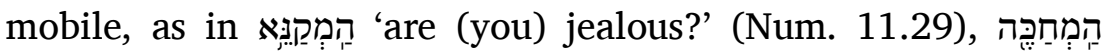

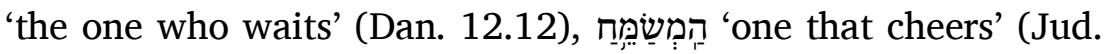

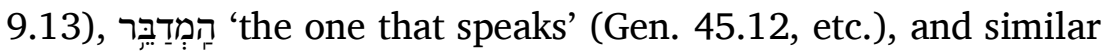

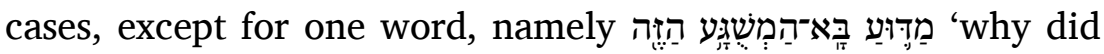
this madman come' (2 Kings 9.11). The number of letters is five but the shewa is not mobile. The reason for this is that the he has not been made heavy. If words consist of more than five letters and he and mem are at their beginning, the shewa in them is sometimes quiescent and sometimes mobile. The rule concerning this is that if the accent is on the fifth letter, or one after this, then the shewa is quiescent, such as 
מתל מַלְכְּכֶם אלדי אללמד סאכן באלשוא אלסאכן ואנחאז אלי אלמים ואלכף תחרך באלשוא אלמתחרך ואנחאז אלי אלכף אלאכר ונחו וישכבו ויקברו ואמתאל דלך

II.S.5.3. ואדא אשתכל אלשוא פי בעץ אלמואצע הל הוא סאכן או

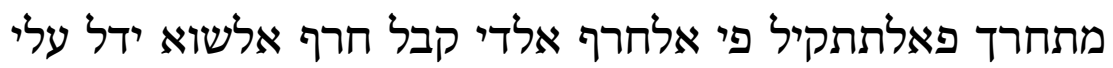

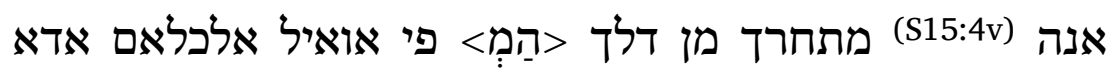
165

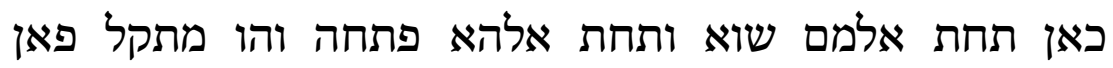

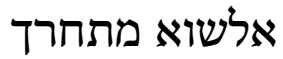

II.S.5.4. יעתבר איצא תחריך אלשוא בעדד חרוף אלכלמה אן כאנת כמסה חרוף פאלשוא מתחרך מתל המקנא המחכה הַמְשַמֵַח המדבר ונחוהם אלא כלמה ואחדה והי מדוע >בא> המשגע הזה אלעדד כמסה חרוף ולם יתחרך אלשוא ואלסבב פי דלך אן אלהא גיר מתקל פאן כאן מן אלכלאם אלתי הי אזיד מן כמסה חרוף ואלהמ הא ואלמים פי אולהא פאלשוא פיהא תארה סאכן ותארה מתחרך פאלשרט פי דלך הוא אן כאן אללחן עלי אלחרף אלכאמס (S9:2r) ומא זאד כאן אלשוא סאכן מתל 
speaking' (Exod. 6.27, etc.), הָמְאָרָרָרִ (Num. 5.19) 'those that

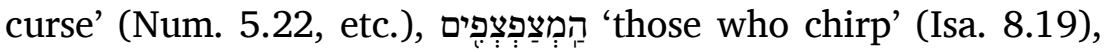

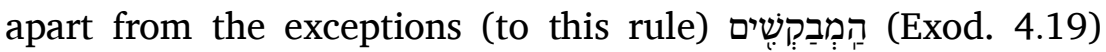
'those who seek', הָמְצרָעצִים 'the lepers' (2 Kings 7.8), and similar cases.

\section{II.S.5.5.}

The shewa on successive identical letters in the middle of a word can also give rise to uncertainty, when shewa is on the first of the two, as to whether this is mobile or quiescent. Consideration should be made as to whether there is heaviness in (the vowel of) the letter before them (i.e. the two successive letters). If this occurs, either through a gaya, or an accent or the lengthening

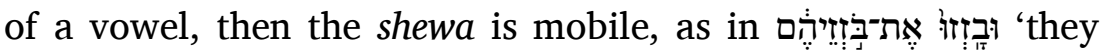

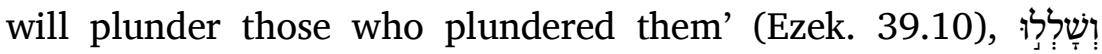
'they will despoil those who despoiled them' (Ezek.

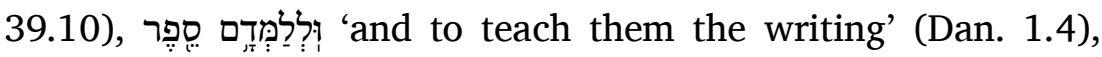
and similar cases, except for six cases, in which heaviness occurs (on the vowel of the preceding letter) but the shewa is not

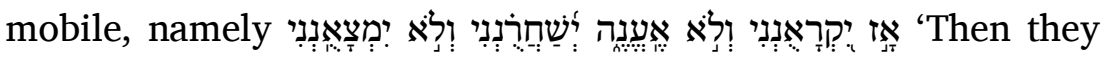
will call upon me, but I will not answer; they will seek me

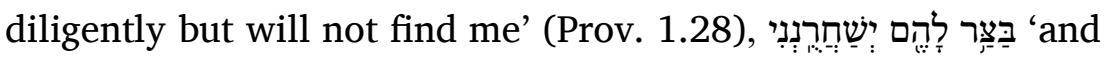

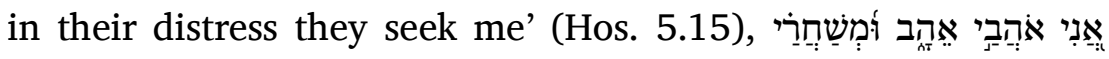

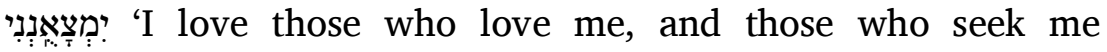

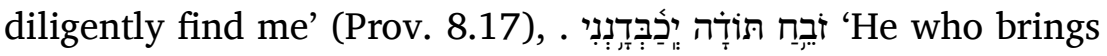
thanksgiving as his sacrifice honours me' (Psa. 50.23). 
המדברים המאררים המצפצפים אלא שואד המבקשים

המצורעים ונחוהמא

II.S.5.5.

וקד ילבס אלשוא פי אלחרפין אלמתראדפין פי וסט אלכלמה אדא כאן תחת אלאול מנהמא שוא אהו מתחרך אם סאכן 180 פליעתבר באלתתקיל פי אלחרף אלדי קבלהמא אן כאן >חאצל> או בגעיה או בטעם או אסתיפא מלך פאלשוא

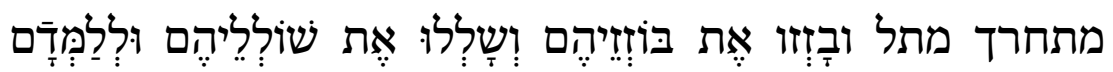
סֵפֶּר ואמתאל דלך מא סוי סת מואצע פאן אלתתקיל חאצל

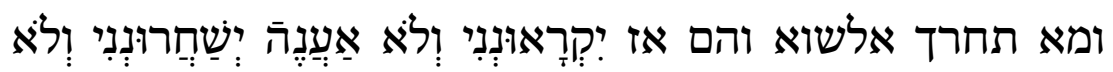
(S9:2v) 185 ימצאונני זובח תודה יכבדנני: 


\section{II.S.5.6.}

Take note that a mobile shewa never occurs on a second letter (of a word) that has a silent (following letter), because it (this second letter) is mobile due to the mobility of the first letter with shewa. A (shewa on) the third letter after (an initial mobile)

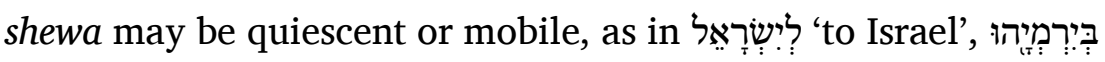

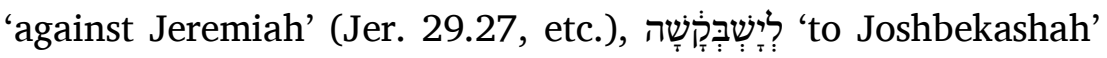
(1 Chron 25.24).

\section{II.S.5.7.}

Take note that when a letter has a vowel under it, the letter is mobile and quiescence occurs in the following (letter), for

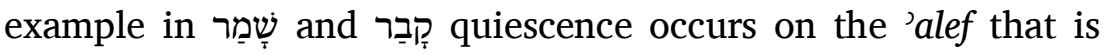
pronounced from within the qames and the patah. 
II.S.5.6.

ואעלם אן אלשוא אלמתחרך לא יקע פי אלחרף אלתאני לה סכון בתה לאנה יתחרך לאגל חרכת אלאול באלשוא ואלתאלת ללשוא קד יכון סאכן וקד יכון מתחרך מתל לישראל בירמיה לישבקשה

II.S.5.7.

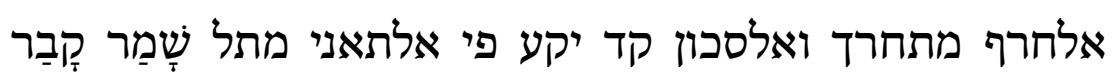
אלסכון יקע פי אלאלף אלכארגִ מן אלקאמצה ואלפאתחה: 


\section{II.S.6.0.}

The (discussion of the) mobile shewa should be divided into various subsections.

\section{II.S.6.1. The First Subsection}

\section{II.S.6.1.1.}

This concerns the influence that it undergoes in connection with the letters $\kappa, \pi, \pi$ and $\nu$. When these four letters are preceded by a letter that is not one of them and under this letter there is shewa, this shewa is pronounced as a short (vowel) with the pronunciation of the vowel that is under the four letters, unless it is appropriate for gaya to be combined with it. If this may appropriately be combined with it, it is pronounced with the pronunciation of the vowel equal (in length), as in ואיזם 'and

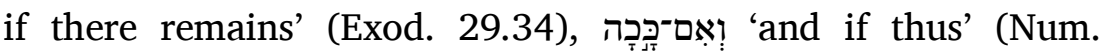

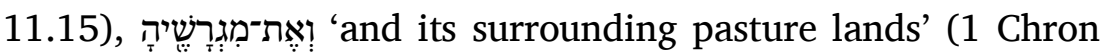

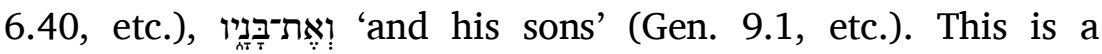
sample of cases with 'alef.

\section{II.S.6.1.2.}

He: When shewa is before he, the shewa is pronounced (with the same pronunciation) as the pointing of the he, for example in

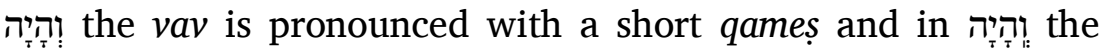
shewa is pronounced with long qames on account of the gacya.

\section{II.S.6.1.3.}

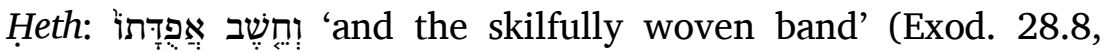

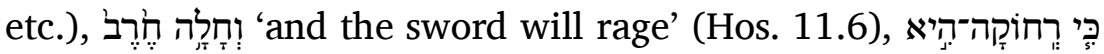
'because it is far' (Jdg 18.28). 


\section{II.S.6.0.}

אלשוא אלמתחרך הו אלמפתן באלפנון

אלפן אלאול II.s.6.1.

II.S.6.1.1.

הו מא יחצל לה מן אלתאתיר פי ארבע חרוף אהּחע פאן הדה

אלארבע חרוף אדא כאן קבל אחדהא חרף מן סואהא תחתה שוא כרגִ דלך אלשוא בכרוגְ אלמלך אלדי תחת אלארבעה חרוף (S12:1v) מכפפא אלא אן כאן יחסן מעה דכול אלגעיה פאן חסן מעה דכולהא כרגִ בכרוגִ אלמלך סוא נחו ואם יותר ואם ככה ואת מגרשיה ואת בניו הדא נמודגִ פי אלאלף

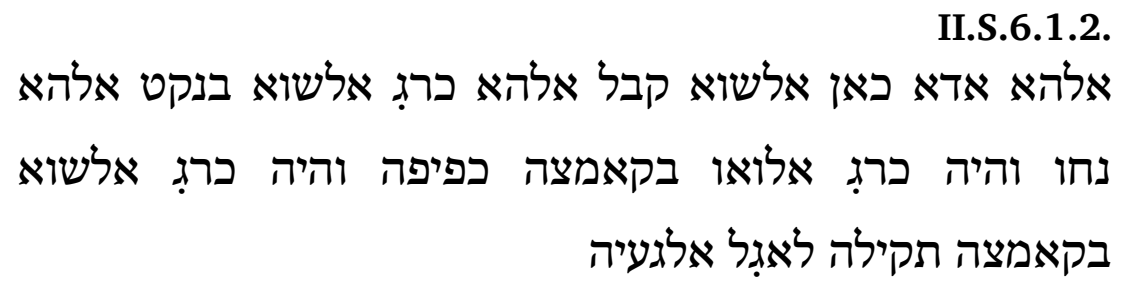

II.S.6.1.3. אלחית וחשב אפדתו וחלה חרב כי רחוקה היא 


\section{II.S.6.1.4.}

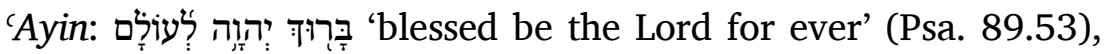

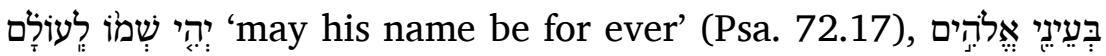

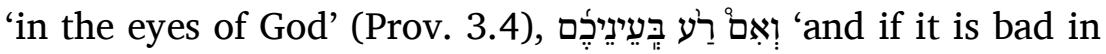
your eyes' (Josh. 24.15).

\section{II.S.6.1.5.}

Now this rule is applied to shewa with the four letters when the shewa is under a letter that is not one of these four. If it is one of

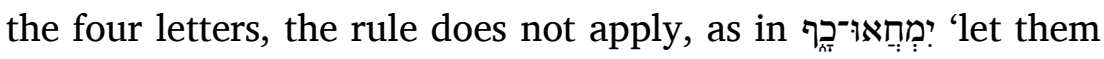

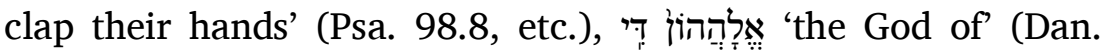
3.28 , etc.).

\section{II.S.6.1.6.}

Take note that when shewa occurs under vav before a letter of (the verbal prefixes) $\aleph$, ,, $\mathrm{J}$ or $\Omega$, it is more suitable (to express) the future than the past. When instead of the shewa a vowel appears under the vav, it is more suitable (to express) the past

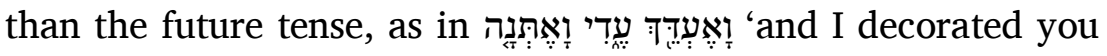

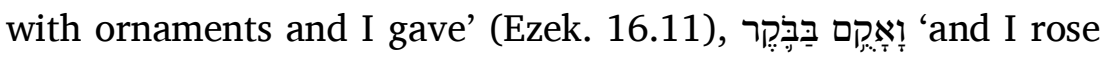
in the morning' (1 Kings 3.21). If a shewa had occurred in place of these qames vowels, the verb would have been future. This is one of the functions of the shewa.

\section{II.S.6.2. The Second Subsection}

\section{II.S.6.2.1.}

When shewa comes before yod, the shewa is always pronounced as hireq, irrespective as to what pointing the yod has, as in

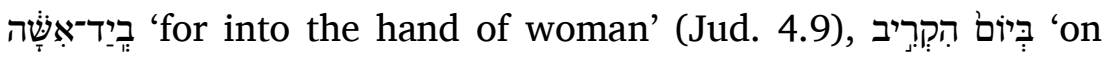

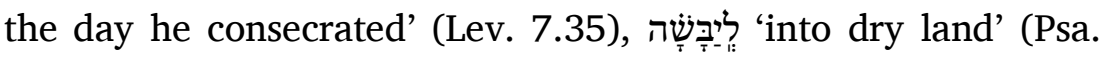
66.6), לִירָּרם 'of Joram' (2 Kings 8.16), and similar cases. 
II.S.6.1.4.

אלעין ברוך יוי לעולם יהי שמו לעולם בעיני אלהים ואם רע

II.S.6.1.5. אלאן הדא אלשרט לאזם פי אלשוא מע אלארבעה חרוף מתי כאן אלשוא תחת חרף מן סוי אלארבעה פאנה אן כאן מן אלארבעה בטל הדא אלשרט נחו ימחאו כף אלההום די

II.S.6.1.6. ואעלם אן אדא גְאת אלשוא תחת ואו קבל (S12:2r) חרף אינת כאנת באלאסתקבאל אחק מן אלמאצי ואדא גְא תחת אלואו עוֹ אלשוא מלך כאן באלמאצי אחק מן אלזמאן אלמסתקבל נחו ואעדך עדי ואתנה ואקום בבקר ולו נְאת אלשוא מוצע הדה אלקואמץ כאן אלפעל מסתקבל והדה הו מן פואיד אלשוא

אלפן אלתאני II.S.6.2.

II.S.6.2.1. אלשוא אדא כאן קבל יוד כרג אלשוא אבדא בנקטה מן אספל ולא יעתבר בנקט אליוד אישיהו מתל כי ביד אשה ביום הקריב ליבשה ליורם ונחו דלך 


\section{II.S.6.2.2.}

Take note that when shewa occurs before yod, it generally indicates the indefinite, whereas a vowel before it indicates the

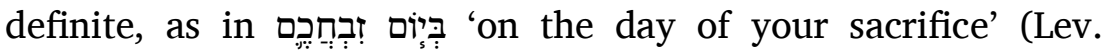

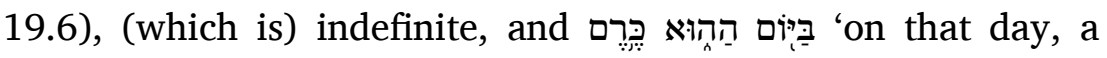
vineyard' (Isa. 27.2), (which is) definite, and so forth.

\section{II.S.6.3. The Third Subsection}

\section{II.S.6.3.1.}

The remainder of the primary letters of Hebrew are seventeen, and to these should be added yod, so they come to eighteen. When shewa is under one of these eighteen at the beginning of a word, or in the middle of a word, where it has the same status (as one at) the beginning (of a word), the shewa is pronounced as a short patah when it is not accompanied by a gaya and as a

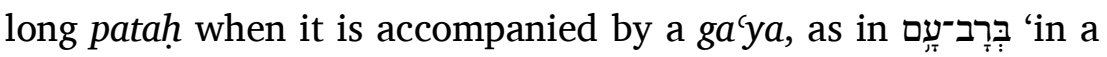

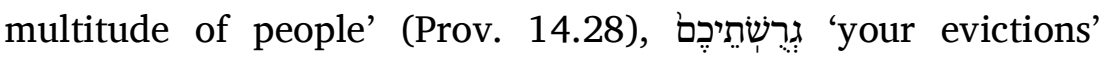

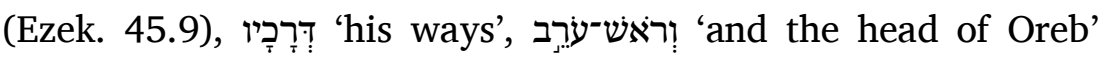

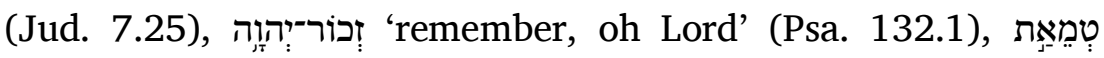

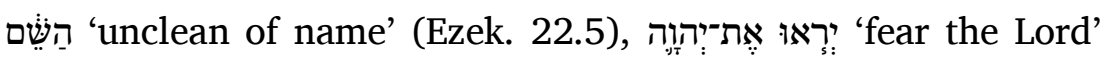
(Jos. 24.14), and other cases with these eighteen letters.

\section{II.S.6.3.2.}

Take note that these eighteen are (pronounced as if) pointed with patah, but it is a feature of this patah that it is only pronounced short. There is no way of (representing) its shortness other than by combining it with shewa. Since, however, the shewa according to their principles does not combine with a vowel under these eighteen letters, they have marked the shewa by itself. They could not have written the 
II.S.6.2.2.

ואעלם אן אלשוא אדא כאן קבל אליוד פי אכתר אלמואצע דלת

עלי אלמנכר ואלמלך קבלה ידל עלי אלמיודע מתל ביום זבחכם

מנכר ביום ההוא כרם מיודע ונחו דלך

II.S.6.3.

II.S.6.3.1.

אלבאקי מן (S12:2v) חרוף אלעבראני אלאצול סבעה עשר ותרד

אליהא אליוד תציר תמאניה עשר אדא כאן אלשוא תחת אחד הדה אלתמאניה עשר פי אול אלכלאם או פי וסט אלכלאם בחית יְִִרי מִִגרי אלאבתדא כרגִ אלשוא בפאתחה כפיפה אדא לם יכן מעה געיה ובפאתחה תקילה אדא כאן מעה געיה מתל ברב עם גרושותיכם דרכיו וראש ערב זכר יוןי טְמאת השם יראו את יוי אלי גיר דלך מן הדה אלתמאניה עשר חרפא

II.S.6.3.2. ואעלם אן הדא אלתמאניה עשר נקטהא הי אלפאתחה ומן חכם הדה אלפאתחה אלמדכורה לא ינטק בהא אלא כפיפה ולא וְגִה לכפתהא אלא כון אלשוא מעהא ולמא לם יכן אלשוא פי אצולהם יִּתמע מע מלך תחת הדה אלתמאניה עשר חרף גְעלו אלשוא פקט (S12:3r) ולם ימכנהם אן יְִעלו אלפאתחה וחדהא 
patah by itself, since it would have been pronounced with its full length. I have discussed this subject at length in The Guide for the Reader, where you will find the matter explained clearly.

\section{II.S.6.4. The Fourth Subsection}

The shewa is never combined with a conjunctive or disjunctive accent on the same letter. This is because an accent cannot combine with a quiescent shewa on account of the incongruity (of their functions), since a letter is made mobile by an accent, whereas a quiescent shewa makes a letter quiescent, and a letter made quiescent by the shewa would have to be made mobile by the accent simultaneously, and this is impossible. Furthermore the mobile shewa gives a letter a mobility that has no endurance,

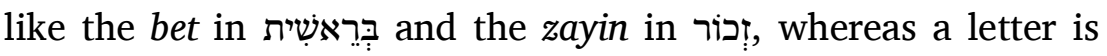
given a stable mobility by an accent and it is given many

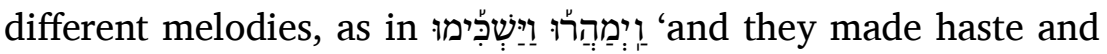
went out early' (Josh. 8.14). So the mobility of an accent cannot be combined with the mobility of the shewa on account of the speed of the mobility of the shewa.

\section{II.S.6.5. The Fifth Subsection}

A letter following a mobile shewa is always rafe, as in בְָָּּם

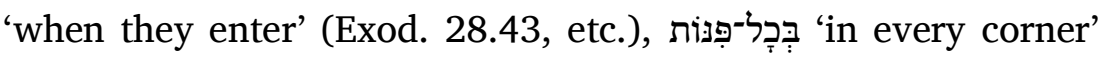

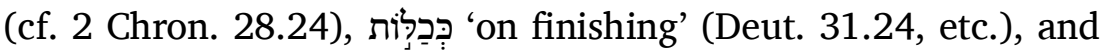
similar cases. The reason for this is that the shewa, since it wishes to have movement and speed, requires the lightness of the letter after it, because dagesh introduces a kind of heaviness in the letter. 
לאנהא תגִי מסתופאה וקד אסתקצית אלכלאם פי הדא אלמוצע פי הדאיה אלקאר עלי מא אנת תגְִה הנאך מבינא

II.S.6.4. אלשוא לא יִִּמע לא מע לחן ולא מע כאדם פי חרף ואחד מעא בתה לאן אלטעם לא יְְתמע מע שוא סאכן מן חית אלמנאקצה לאן אלטעם יתחרך בה אלחרף ואלשוא אלסאכן יסכן אלחרף פכאן יִגב אן יכון אלחרף סאכן באלשוא מתחרך באלטעם פי חאלה ואחדה והדא פאסד ולאן אלשוא אלמתחרך יחרך אלחרף חרכה לא תבאת פיהא כאלבא מן בראשית ואלזאי מן זכוֹר ואללחן יתחרך בה אלחרף מוצעה וינגם נגמאת

כתירה מתל וימהרו וישכימו פלא יגְתמע חרכה אללחן (S12:3v) מע חרכה אלשוא לסרעה אלשוא פי אלחרכה

It.s.6.5. אלשוא אלמתחרך לא יכון אלחרף אלתאני מנה אבדא אלא רפי מתל בבואם בכל פנות ככלות ונחו דלך ואלוגְה פי דלך אן אלשוא למא אראד אלתחרך ואלסרעה אחתאג אלי כפה אלחרף אלדי בעדה לאן אלדגש הו תקל פי אלחרף עלי וגְה 


\section{II.S.6.6. The Sixth Subsection}

\section{II.S.6.6.1.}

A mobile shewa does not combine with a vowel on any of the Hebrew letters except the four letters $\boldsymbol{N}, \pi$, $\pi$ and $\nu$, for example

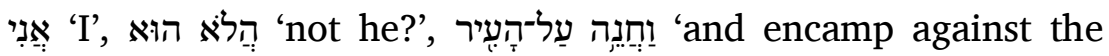
city' (2 Sam. 12.28), עִ 'go up!', and similar cases. If one sees this on other letters in some codices, this is because the scribe inteneded thereby to remove uncertainty, for example

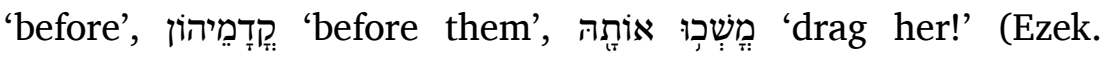

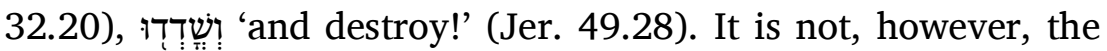
opinion of all (that this practice is permissible). So you see that everybody combines shewa with a vowel under the four letters but only a few combine a vowel with shewa under the other eighteen letters, there being no consensus as to whether this (practice) be erroneous or not.

\section{II.S.6.6.2.}

Take note that if one wishes to remove a vowel from one of the four letters $\Sigma, \pi$, or $y$, and pronounce the shewa, that would be permissible. It is not permissible, however, to mark the vowel by itself, since a vowel by itself would be pronounced with its full length. So, understand this! 
אלפן אלסאדס II.S.6.6.

II.S.6.6.1.

אלשוא אלמתחרך לא יִּתמע מע מלך פי חרף מן חרוף

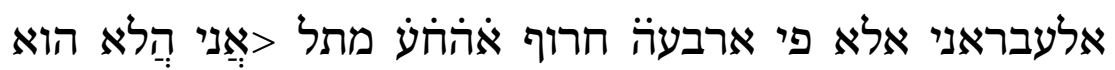

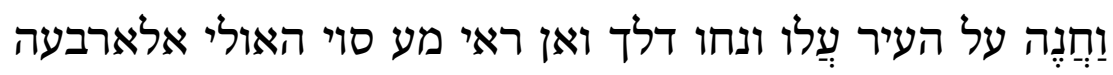

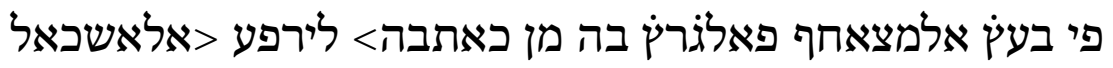

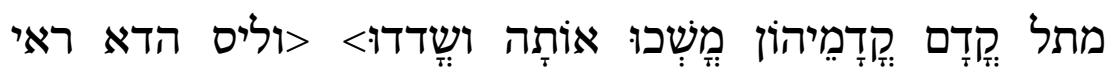
אלכל> (S12:4r) ולדלך תרי אלכל יִיגמעו אלשוא מע אלמלך תחת אלארבעה חרוף ומא סואהא מן בקיה אלחרוף אלאקל ינְמע אלמלך מע אלשוא פי אלמגלטאת ופי גיר מגלט מן אלתמאניה

$$
\text { עשר לא יגמע }
$$

II.S.6.6.2.

ואעלם אן לו אראדו אן יחדפו מן אלארבעה חרוף אהז亡ע

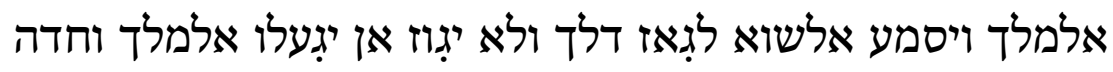
מן חית אן אלמלך וחדה יסתופא פאפהמה

255 بֵני...257 כאתבה] S20:8r פני יהוָה הלא היא [ [ עליו ונחו דלך ואן

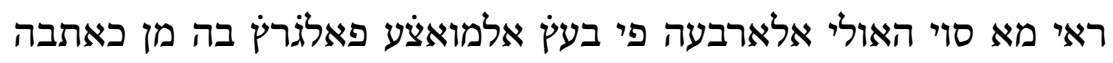

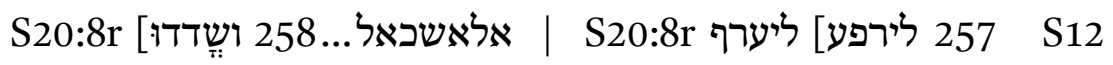

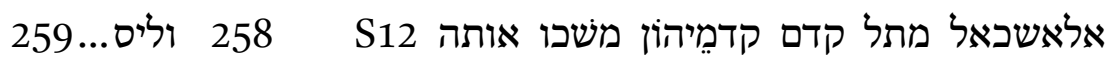

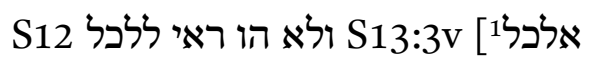




\section{II.S.6.7. The Seventh Subsection}

When a shewa is combined with a vowel under a letter, the vit

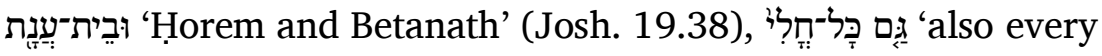
sickness' (Deut. 28.61). Take note that the maintenance of the mobility of the shewa is more important than the maintenance of the full length because if they did not need to shorten the vowel and (read it) quickly, they would not have marked shewa with it.

\section{II.S.6.8. The Eighth Subsection}

Shewa is combined with only three vowels. These are qames, patah and segol. This is because these three may be read with pause and also with speed.

\section{II.S.6.9. The Ninth Subsection}

When shewa is at the beginning of a word, it is always mobile,

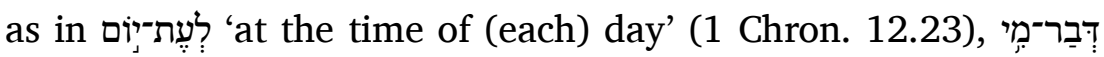

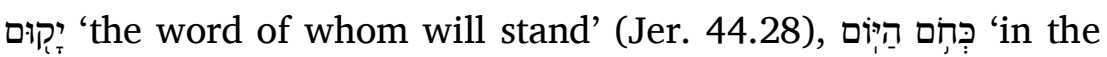
heat of the day' (Gen. 18.1), and similar cases. This is because it is not permissible to begin (a word) with a quiescent letter. You will find the issues concerning this aspect explained in The Guide for the Reader. God knows best.

\section{II.S.6.10. The Tenth Subsection}

A mobile shewa is followed by quiescence in the third letter after it, or one greater (in number than the third), as in, 'to Joshbekashah' (1 Chron 25.24), לִיְְקְמָעָם 'to Jokmeam' (1 Kings 4.12), and the like, and as in cases in which 
II.S.6.7. אלשוא אדא אִּתמע מע מלך תחת חרף מנע אלמלך מן אן יסתופי חטה מן אלתקל מתל חרם ובית ענת גם כל חלי ואעלם אן תבות חרכה אלשוא אולי מן תבות אסתיפא אלמלך לאן לו לם יחתאגִו אלי כטף אלמלך וסרעתה לם יגעלו מעה (S12:4v)

אלשוא

II.S.6.8. לא יגִמע אלשוא אלא מע תלתמו מלת מלוך פקט והי אלקאמצה

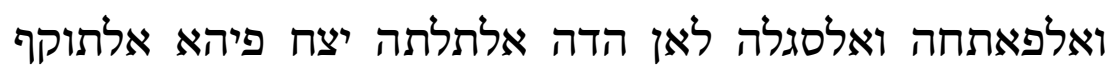
ואלסרעה: - (אלפתוח

II.S.6.9. אלשוא אדא כאן פי אול אלכלאם יכון אבדא מתחרך מתל לעת יום דבר מי יקום >כְחוֹם היום> ונחו דלך לאן לא יצח אלאבתדי בסאכן ואנת תגִד אלכלאם פי הדא אלפן משרוחא פי הדאיה אלקאר ואללה אעלם

II.S.6.10. אלשוא אלמתחרך יכון בעדה סכון פי אלחרף אלתאלת ומא

זאד נחו לישבקשָה ליקמעם ואמתאלהמא ממא אלסכון פי 
the quiescence is in the third letter and also in what is beyond the third letter, such as אֶלה 'God' and בֶּרים 'cypresses'.

\section{II.S.6.11. The Eleventh Subsection}

A mobile shewa does not come next to a (mobile) shewa either at the beginning of a word, or in the middle of it, or at its end. This is because a word is mobile (with a vowel) and what attaches to this mobile component when it begins with (a mobile) shewa is of a lesser degree of mobility. A quiescent letter may follow these two. Therefore two mobile (shewas) are not combined together, in the way that two quiescent ones can combine.

\section{II.S.6.12. The Twelfth Subsection}

Two quiescent shewas are not combined except at the end of a

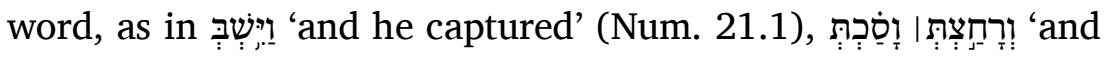
you will wash and anoint yourself' (Ruth 3.3). Take note that when shewa under shin and sade is quiescent and bet and tav remain after it, they must obligatorily be made quiescent, because they do not have a letter next to them to which they could move towards.

\section{II.S.6.13. The Thirteenth Subsection}

It is not possible to have a succession of two adjacent shewas the first of which is mobile and the second quiescent. Rather the first must be quiescent and the second mobile. Take note that shewa may be construed as a successive sequence (of two) even

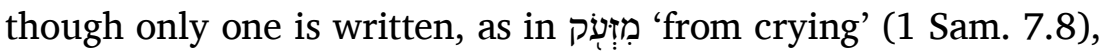

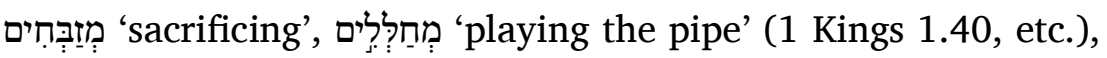

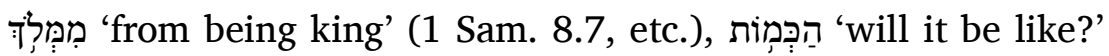
(2 Sam. 3.33). The reason for this is that the letter is pronounced as two letters. This is the custom of Hebrew, 
אלתאלת ומא זאד עלי אלתאלת מתל אלהים (S12:5r) ברושים

אלפן אלחאדי עשר II.S.6.11. 285 שוא מתחרך לא ינְאור שוא לא פי פי אול אלכלאם ולא פי וסטה ולא פי אכרה לאן אלכלאם אנמא יכון מתחרך ומא ילחק באלמתחרך פהו אקל חרכה מן אלמתחרך אדא אבתדי באלשוא ואלסאכן קד יתבעהמא פלדלך לם יקתרנא מתחרכין כמא יקתרנא אלסאכנין

אלפן אלתאני עשר II.S.6.12. שואאין סאכנין לא יקתרנא אלא פי אכר אלכל אלמה מתל וישֶבּ ורחצתת וסכתת ואעלם אן למא סכן אלשוא אלדי תחת אלשין ואלצדי ובקי בא ותו לם יכן בד מן תסכינהמא לאן ליס להמא חרף יְִאורהמא פיתחרכא אליה

II.S.6.13. שואאין מתראדפין אלאול מתחרת עלת ואלתאני סאכן לא יִגוז תראדפהמא אלא אן יכון אלאול סאכן ואלתאני מתחרך (S12:5v) ואעלם אן תם שוא בניתה עלי אלתראדף ואן כאן ליס אלא 300 פי דלך אן אלחרף יכרגִ בחרפין פהדה סירה פי אלעבראני והוא 
namely that every letter with strengthening, I mean with dagesh, in the middle of a word, where it does not have the status of beginning (a word or syllable), under which there is shewa, is pronounced as two letters.

\section{II.S.6.14. The Fourteenth Subsection}

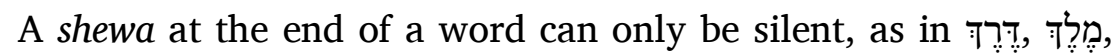
and similar cases. 
אן כל חרף משדד אעני מדגוש פי וסט כלמה בחית לא יִִרי מִִרי אבתדי ותחתה שוא יכרגִ בחרפין

אלפן אלראבע עשר אלכומ. II.S.6.14.

305 ומלך ואמתאלהמא אכר אלי 


\section{II.S.7.0.}

\section{SECTION ON THE NAMES OF THE VOWELS AND THEIR PLACE OF ARTICULATION}

\section{II.S.7.1.}

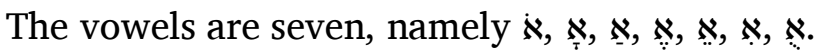

\section{II.S.7.2.}

The first is 'the point above' (i.e. holem) because it moves along the surface of the whole mouth. Its name is holem. The meaning of this is 'fullness', because it fills the whole mouth. They have derived (the name) from one of the languages that they used.

\section{II.S.7.3.}

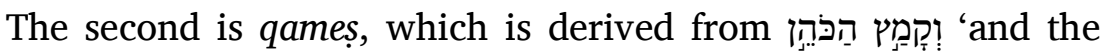
priest will grasp' (Lev. 5.12, etc.), because it grips the mouth.

\section{II.S.7.4.}

The third is patah, which opens the whole mouth, from

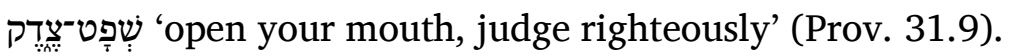

\section{II.S.7.5.}

The fourth is segol, which consists of three dots below, as if they were a bunch of grapes.

\section{II.S.7.6.}

The fifth consists of two dots below in a line. Its name is sere, 


\section{II.S.7.0. \\ פצל פי אסמא אלמלוך ומחלהא}

II.S.7.1.

אלמלוך סבעה והי אָ אָ אַ אֶ אֵ אִ אִ

II.S.7.2.

אלאול אלנקטה מן פוק לאנה יסיר עלי סטח אלפם כלה ואסמה חלם ומענאה (S12:6r) מלו לאנהא תמלא אלפם כלה ואשתקוה

מן בעץ אללגאת אלתי מעהם

II.S.7.3.

אלתאני קאמצה משתקה מן וקמץ הכהן לאנהא תקבץ אלפם

II.S.7.4.

ואלתאלת אלפאתחה והי תפתח כל אלפם מן פתח פיך שפט

צדק ואנות

II.S.7.5.

ואלראבע סגולה והי אלתלתה נקט מן אספל כאנהא ענקוד

II.S.7.6.

ואלכאמסה הי נקטתין מן אספל מצטפה אסמוהא צִירי 
the meaning of which is 'splitting', because it splits between the teeth. They have derived it from the languages that they used.

\section{II.S.7.7.}

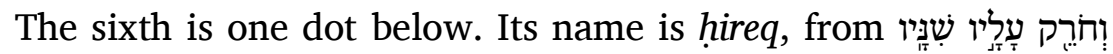
'and gnashes his teeth against him' (Psa. 37.12). The meaning of this is that the teeth make a squeaking sound with it.

\section{II.S.7.8.}

The seventh consists of three dots (written) obliquely. It may be replaced by one dot in the heart of vav. Its name is shureq,

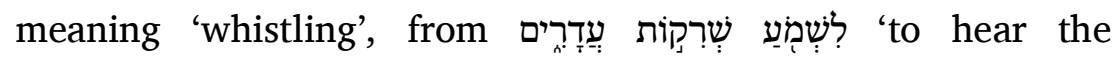
whistlings of the flocks' (Jud. 5.16), because it gathers the lips together. 
ומענאהא שאק לאנהא תשק בין אלאסנאן וקד אשתקוהא מן אללגאת אלתי מעהם ומאנאת יחת

II.S.7.7.

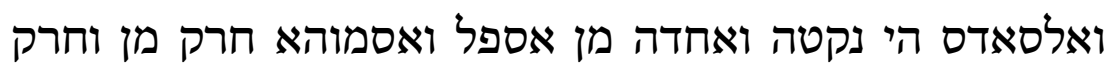
עליו שניו ומעני דלך אן תצר בהא אלאסנאן וארה מסא ואסא ורא

II.S.7.8.

ואלסאבע תלתה נקט מוארבה וקד יכון עוצהא נקטה ואחדה פי

קלב >אלואו (S12:6v) אסמוהא שרק> במעני אלצפיר מן >לשמוע> שריקות עדרים לאנהא תגְמע אלשפתין

319 חרק] חֶרֶק S1:8r 321 מוארבה] מורב S6:11r 322 אלואו.. שרק] אלואו (+ אסמוהא מפק לאנהא תגִמע אלשפתין ואלתלתה נקט

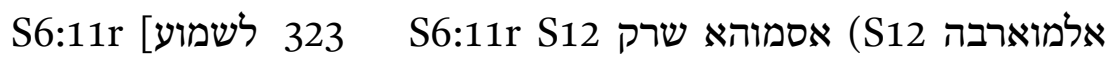
אלשמע S12 S3:10v אסמארבות 


\section{II.S.8.0.}

\section{DISCUSSION CONCERNING THEIR PLACE OF ARTICULATION}

\section{II.S.8.1.}

The place of articulation of holem is the root of the tongue and the place of swallowing, and it moves over the surface of the entire mouth.

\section{II.S.8.2.}

The place of articulation of qames is slightly above the root of the tongue, this being the (first) third of the tongue, and its movement is to above the palate.

\section{II.S.8.3.}

The place of articulation of patah is the surface of the tongue downwards.

\section{II.S.8.4.}

The place of articulation of segol is the contraction of the sides of the mouth and its movement is upon the lower surface of the mouth.

\section{II.S.8.5.}

The place of articulation of sere is the teeth, without closure.

\section{II.S.8.6.}

The place of articulation of hireq is the closure of the teeth with force.

\section{II.S.8.7.}

The place of articulation of shureq is the lips gathered together (as if for) whistling. 


\section{II.S.8.0. \\ אלכלאם פי מחלהא}

II.S.8.1.

מחל אלחלם עקר הלשון ובית הבליעה ומסירה עלי סטח אלפם

כלה מחו

II.S.8.2.

מחל אלקאמצה פוק אצל אללסאן קליל והי תלת אללסאן

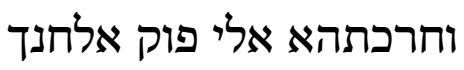

II.S.8.3.

מחל אלפאתחה סטח אללסאן מן אספל

II.S.8.4.

מחל אלסגלְה צם אגאב אלפם וחרכתהא עלי סטח אלפם

II.S.8.5. מחל אלצירי אלאסנאן בגיר טבק

II.S.8.6. מחל אלחרק טבק אלאסנאן בקוה

II.S.8.7. מחל אלשרק הוא שלשפתין מצמומתין באלצפיר 


\section{II.S.9.0.}

\section{SECTION CONCERNING THE GA'YA}

The gaya is an exhalation in speech, which conducts the reading along and carries it forward in a beautiful manner, animating the reader and moving him to read more. One reader omits it in some places whereas another reader sustains it. In sum, it has no principle, because it is not an accent, like a disjunctive accent or a conjunctive accent. It is marked on a slant to the right of the reader, similar to the marking of tifha and mayela. It is said that the gaya has no principle. It is never accompanied by maqqef, which is a line that links two words on account of the fact that one word does not have a disjunctive or conjunctive accent. This is because any word that has an accent does not have maqqef, unless a gaya can come before the accent, in which case a word may contain an accent and maqqef in some places. There are, however, some places from which

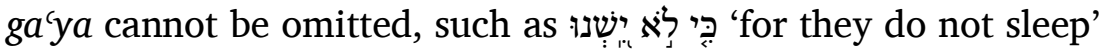
(Prov. 4.16), which is from 'sleeping and slumber'. If you were

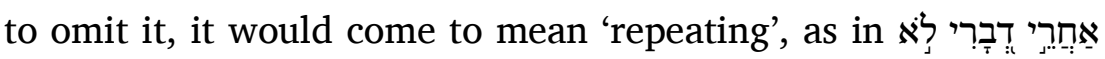
ישׁׁי 'after my word they did not speak' (Job 29.22), and similar cases where the meaning changes on account of it. 


\section{II.S.9.0. \\ פצל פי אלגעיה (S12:27r)}

אלגעיה הי תנפס פי אלכלאם ותזף אלקראה ותסוקהא אחסן סיאק ותנשט אלקאר ותחרכה אלי אלתזיד פי אלקראה פקאר יחדפהא מן בעץ אלמואצע וקאר יתבתהא ובאלגִמלה לא אצל

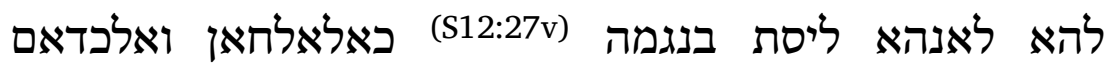
>ונצבהא הו נצב בתמייל> אלי ימין אלקאר שביה בנצב אלטפחה ואלמאילה וקד קיל > אין אָב ללגעיה > והי אבדא יכון מעהא אלמקף והי כטה תוצל בין אלכלמתין אדא כאנת אלכלמה ליס פיהא לחן ולא כאדם לאן כל כלמה פיהא טעם לא יכון פיהא מקף אלא אן תגִי אלגעיה מן קדאם >אלטעם> פיציר פי אלכלמה טעם ומקף פי בעץ אלמואצע >גיר אן תם מואצע לא ימכן חדף אלגעיה מנהא> מתל כי לא ישנו אלדי הו מן

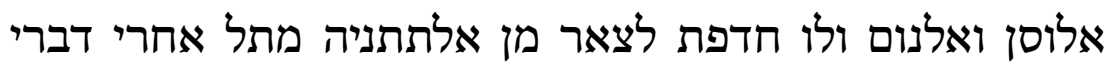

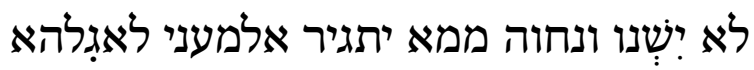

340 ונצבהא...בתמייל] S19:5v S2:17v וינצבהא פהו נצב בתמ] [ ]

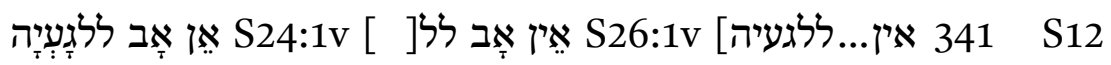

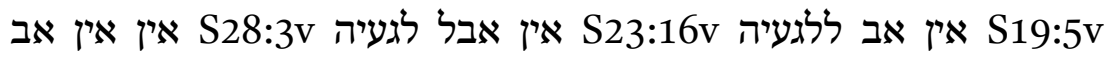

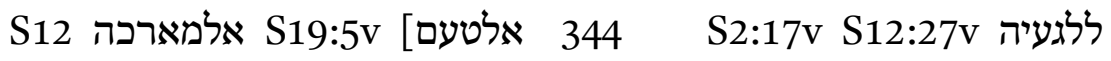
345 גיר ... S196 מנהא] S19:5v תם מוצע לא ימכן חדף אלגעיה מנה S12: 


\title{
COMMENTARY ON HIDĀYAT AL-QĀRI
}

\author{
LONG VERSION
}

\section{$>$ II.L.0.0.}

The long version opens with an introduction, which presents various aspects of the background of the ensuing work. 'Abū al-Faraj Hārūn included such authorial paratexts in his other works. His grammatical work al-Kitāb al-Kāfī contains a preface and an introduction (ed. Khan, Gallego and Olszowy-Schlanger 2003, 1019). The abridgement of al-Kitāb al-Kāfi known as Kitāb al-'Uqūd fì Taṣārîf al-Lugha al-'Tbrāniyya 'The Book of Rules regarding the Grammatical Inflections of the Hebrew Language', which was compiled by an anonymous contemporary of 'Abū al-Faraj Hārūn, likewise contains an introduction (ed. Vidro 2013a, 2225). 'Abū al-Faraj Hārūn's glossary of difficult words, which is referred to as Tafsir 'Alfäz al-Miqrā 'Explanation of the words of Scripture' and several variant titles, contains a postface added at the end of the work, which served the same purpose as a preface and an introduction (Goldstein 2014).

Authorial paratexts, in the form of prefaces, introductions and postfaces, are a characteristic feature of contemporary medieval Arabic literary compositions. ${ }^{1}$ The addition of such a paratext, therefore, in the works of 'Abū al-Faraj Hārūn reflects convergence with the Arabic literary models.

\footnotetext{
${ }^{1}$ See Freimark (1967) and the discussion and references in Goldstein (2014).
} 
An introductory paratext is found in some earlier works written by Jewish scholars, such as the Masoretic treatise Seder ha-Simanim (Allony 1965, ט-) and some works of Saadya in the tenth century, such as his lexicon ha-'Egron (ed. Allony 1969a, 148-63) and his Bible commentaries (Stroumsa 2007).

The beginning of the introduction to the long version of Hidāyat al-Qāri' is missing. If we compare it, however, with the corresponding introduction in the short version, which has been preserved in its entirety, it can be safely assumed that only a short amount of text is missing.

The introduction can be divided into various components, many of which contain standard themes in such authorial paratexts. §II.L.0.1. discusses the reasons why the principles of biblical reading need to be studied. §II.L.0.2.—§II.L.0.6 concern the historical background of the Tiberian reading and its antiquity. §II.L.0.7.—§II.L.0.8. describe the history of the discipline of fixing rules for the correct reading. §II.L.0.9. explains the author's motivation to write the work and summarizes its contents.

'Abū al-Faraj states in SII.L.0.9. that the purpose of the work was essentially compilatory, in that it brings together in a comprehensive way specialist works and oral teachings of his predecessors, who remain anonymous. This section contains a 'request to compose' without specifying the name of the requester. This is a standard feature of Arabic introductions of the period and it is often no more than a fictional trope (Freimark 1967, 36-40). As is typical, this 'request to compose' is combined with a modesty trope in which the author acknowledges his own imperfections. 
In some cases, we know that medieval Karaite works were commissioned by specific individuals. In the postface to his Kitāb 'Alfāz al-Miqrā, 'Abū al-Faraj indicates the name of the requester, viz. 'Abū al-Ṭayyib Samuel ibn Manșūr (Goldstein 2014), who commissioned the work for his children. Another case is the short commentary of 'Abū al-Faraj Furqān ibn 'Asad (Yeshu'a ben Yehuda), in the introduction of which it is indicated that the work was commissioned by the wealthy patron 'Abū al-Hasan Dā' $\bar{u} d$ ibn 'Imrān ibn Levi (Khan 1993; Polliack 1997, 47-48). An alternative process is attested in the manuscripts containing the grammatical commentary of the Karaite Yūsuf ibn Nūh, known as the Diqduq, in which there is a document indicating that the author dedicated the work as a pious foundation to the Karaite community (Khan 2000b, 153-54).

The introduction to Hidāyat al-Qāri' has a particular focus on the accents rather than the consonants and vowels. This suggests that the main interest of 'Abū al-Faraj in the work were the accents. Indeed one early source that is apparently referring to Hidāyat al-Qāri' calls it Kitāb al-'Alhān 'The Book of the Accents' (see $\S$ II.Int.0.3.). One of the later European recensions of the work, furthermore, had the title Ța'ame ha-Miqra 'The Accents of the Bible' (see vol. 1, §I.0.13.1.).

It should be noted, however, that the adducing of examples of different positioning of accents as a means of demonstrating the importance of the knowledge of correct reading in SII.L.0.1. has a close counterpart in the introduction by 'Abū al-Faraj Hārūn to his grammatical work al-Kitāb al-Kāfi, which demon- 
strates the importance of the knowledge of grammar. A large proportion of the introduction of al-Kitāb al-Kāfi (ed. Khan, Gallego and Olszowy-Schlanger 2003, 12-19) concerns the positioning of accents and, indeed, several of the examples are the same as those presented in the introduction to Hidāyat al-Qāri'. The shared examples, moreover, are used to demonstrate the same points. These include the following. The accent position can distinguish between past tense, e.g. הַּשָׁבָה (Ruth 2.6) 'who returned' and present tense, e.g. וְשָָָָׁה (Lev. 22.13) 'and she returns'. The position of the accent can distinguish between lexical meaning,

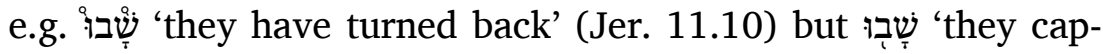
tured' (Gen. 34.29). Furthermore, the same issues of accent position with overlapping examples also occur in §I.1.1. of al-Kitāb $a l-K a \bar{f} i \overline{~ a n d}$ in a passage in 'Abū al-Faraj Hārūn's reworking of Ibn Nūh's commentary on the Pentateuch (Goldstein 2014, 367).

It is likely, therefore, that the use by 'Abū al-Faraj of the arguments relating to accent position in his introduction to Hidāyat al-Qāri' was to some extent motivated by the fact that similar argumentation was already at hand in passages in his other works. Distinction of meaning arising from accent position was, moreover, a particularly salient demonstration of how precise knowledge of the language is important for correct interpretation of Scripture.

\section{II.L.0.1.}

לגה אלרגוע ... לגה אלסבי

lexical class of 'returning' ... lexical class of 'capturing' 
In the linguistic thought of Karaite grammarians of the tenth and eleventh centuries, inflections and derivative forms of a verb were said to belong to a particular lexical class. This was expressed by the Arabic term lughah typically followed by an abstract Arabic verbal noun in genitive annexation, as is the case here (al-rujüc 'returning', al-saby 'capturing'), or by the Hebrew term lashon followed by a Hebrew, or occasionally Aramaic, abstract noun in annexation, e.g. לשון ברכה 'lexical class of blessing' (§II.L.3.2.7.), לשון דחילה 'lexical class of fearing' (§II.L.3.1.). A lexical class was a class of attested linguistic forms sharing a common kernel of meaning and common letters. Such a lexical class does not include words that are related in meaning but have no letters in common. The common letters that embrace all words belonging to a lexical class are in most cases equivalent to what we would call the root letters. The medieval Karaite grammarians of the tenth and eleventh centuries, however, did not have a fully developed concept of an abstract triliteral root as the base of derivation in their linguistic theory (Khan 2000b, 78-82; 2013a; 2013b).

The use of the term lashon with this sense of lexical class is found in earlier Hebrew Masoretic treatises, e.g. Diqduqe haTécamim (ed. Dotan 1967): לשון ברכה 'lexical class of blessing' (§21), לשון אכילה 'lexical class of eating' (§22), לשון ירידה 'lexical class of descending' (\$25). The grammatical use of the term lashon ultimately has its origin in the Rabbinic tradition, where it is used broadly in the sense of linguistic form. Such broader usage is still found in the text of Hidāyat al-Qāri' in cases such as לשון 


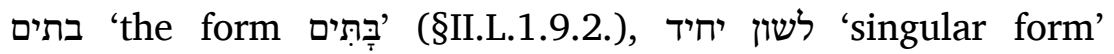
(§II.L.3.2.1.).

\section{II.L.0.2.}

If one were to say "What do you say concerning the formation of these accents?', the response would be that they originated by convention among the people of the language, by the help of which they fully expressed their purposes, as in the aforementioned examples and others. They established them by convention, just as they established the vowels by convention, as will be explained.

This reflects a rationalist and anthropocentric view of the origin of language that 'Abū al-Faraj expresses elsewhere in Hidāyat alQāri' and in his grammatical works. According to this view, language did not develop by revelation from God but rather developed among the primeval speech community of humans by convention in order to fulfil their needs of communication. The primeval speech community is referred to as 'the people of the language' ('ahl al-lugha). It appears that this was intended to be the primeval community of Hebrew-speakers. Discussion of the conventional origin of language elsewhere in Hidāyat al-Qāri' is found in sections concerning the origin of letters and vowels, e.g. §II.L.1.1.1. §II.L.1.1.2., §II.L.1.4.1., §II.L.1.8.2., §II.L.2.2.1. In §II.L.2.2.1. there is a discussion of the role of the language of God in the development of language by conventional agreement. In his grammar al-Kitāb al-Kāfi, 'Abū al-Faraj describes how various aspects of grammatical structure, such as verbal inflections and 
the expression of gender and number, would have arisen by convention within the primeval speech community to fulfil their needs of communication. ${ }^{2}$

The notion of the conventional origin of language was adopted by 'Abū al-Faraj from the rationalist views of language that were espoused by the Muslim theological movement known as the Mu'tazila. The Mu'tazila, in turn, had received this from the Aristotelian tradition of the conventional origin of meaning of sounds in language (Allen 1948; Kretzmann 1974) through the Arabic translations of Aristotelian texts at the period. Muslim philosophers whose thought was based in the Aristotelian tradition also adopted this concept of the origin of language, e.g. al-Fārābi (d. 950), who wrote a commentary on the Arabic version of Aristotle's De Interpretatione, where Aristotle expressed his arguments on this question. ${ }^{3}$

The leading Karaite intellectuals of the period adopted many aspects of Mu'talizite thought (Wolfson 1979; Sklare 2017). They followed in particular the so-called Bahshamiyya Mu'tazilite school of Bașra, which was founded by students and followers of 'Abū Hāshim al-Jubbā'ì. In the second half of the tenth century and the eleventh century, they were influenced especially by the central figures of this school such as 'Abū 'Alì ibn Khallād and 'Abd al-Jabbār al-Hamadhānī. Yūsuf ibn Ibrāhīm haKohen al-Bașir, a prominent scholar in the Karaite Jerusalem

\footnotetext{
${ }^{2}$ The various passages in al-Kitāb al-Kāfi have been gathered together by Gallego (2003).

${ }^{3}$ See this commentary of al-Fārābī (ed. Beirut 1960, 27, 50-51) and Zimmermann's translation (1982, xli, 12).
} 
school, who was a contemporary of 'Abū al-Faraj Hārūn, was particularly closely engaged with the Bahshamiyya school led by 'Abd al-Jabbār and wrote refutations of 'Abd al-Jabbār's opponents (Sklare 2017, 159, 163).

The rationalist notion of the origin of language through conventional agreement among humans can be traced to 'Abū Hāshim al-Jubbā'ī (d. 933) of the Bașran Mu'talizite school and

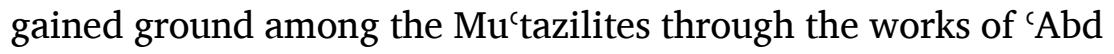
al-Jabbār (d. 1026) and 'Abū al-Ḥusayn al-Bașrī (d. 1044) (Weiss 1974, 35). The Mu'tazalite view of the origin of language by convention was adopted by various Karaite scholars of the Jerusalem school other than 'Abū al-Faraj Hārūn, such as Yūsuf al-Bașīr (Vajda 1974, 61-62) and 'Abū al-Faraj Furqān ibn 'Asad (also known as Yeshu'a ben Yehudah) (Zwiep 1997, 149-58).

The key Arabic terms that are used by the Mu'tazilites for convention are 'isțilāh and verbal forms from the root $w$ - $\underline{-}^{-}$, , especially muwād $a^{c} a$ and tawa $\bar{d} u^{c}$. The latter was the term favoured by 'Abd al-Jabbār in his discussions of the origin of language (Peters 1976, 304-5). 'Abū al-Faraj Hārūn uses both of these terms in his references to the conventional origin of language. The terms muwāḍa' $a$ and tawāḍ $u^{`}$ appear to be literal translations of the Greek term $\sigma u v \theta \dot{\eta} x \eta$ 'convention' in the Aristotelian corpus, all of which have the basic meaning of 'putting together'.

In the passage in §II.L.0.2. the focus is on the origin of the accents, which are said to have arisen by convention among the 'people of the language', just as they established the vowels by convention, to achieve needs such as the distinctions of meaning described in §II.L.0.1. This would relate to stress position rather 
than musical cantillation and so would be a feature of natural speech. The passage then goes on to say that the arrangement (tartib) of the accents may have been based on the practice of the Levites. This is most likely referring to the fixing of the sequence of different pitch accents in the musical cantillation. In a discussion of the origin of the vowels in SII.L.2.18., it is stated that it is possible that the people of the language formed the shapes of the vowels just has they formed the shapes of the letters. It is also possible that the people of the language used to use them in conversation without their knowing any (written) form for them.' In 'Abū al-Faraj's discussion of the origin of the accents in §II.L.0.2., it is not clear whether he is referring to both the written accent signs and the oral reading or only to the oral reading.

The view of the origin of the accents and vowels by convention was abandoned by later Karaites, after the dispersal of the Karaite Jerusalem school consequent upon the capture of Jerusalem by the Crusaders in 1099. The Karaite Judah Hadassi, who was active in the middle of the twelfth century in Constantinople, for example, adopted a revelationist view of their origin, and argued that the original tablets that were given to Moses on Mount Sinai must have had the vowels and accents:

... for without the five vowels, which are [represented by] the vowel signs, a word could not be articulated nor could it be understood without the pronunciation of the vowels and accents. ${ }^{4}$

\footnotetext{
${ }^{4}$ Sefer 'Eshkol ha-Kofer (ed. Eupatoria 1836, 70a): כי בלא חמשת הקולות שהם מלכי הנקוד לא תולד המלה ולא תעמוד בפה ולא יודע מה היא כי אם בנועם נקודים תוטעמים. See further Khan (1992, 173).
} 


\section{$>$ II.L.0.3.}

This section refers to the devastation of Jerusalem by the Romans, who are referred to figuratively as 'wicked Edom', i.e. Esau, the brother and enemy of Jacob. This was a trope that developed early in Rabbinic tradition (Feldman 1992, 47-48). The term here includes also the Byzantine rulers. The reference to pilgrimage to Tiberias and Gaza is evidently referring to the Byzantine period. Pilgrimage to Gaza, Tiberias and Zoar in the Byzantine period are mentioned also by other medieval Karaites. ${ }^{5}$ One such reference is by Sahl ben Mașliah ha-Kohen in the preface to his Book of Precepts:

After having left that place (i.e. Jerusalem), it remained for over five [hundred] years as rubble and dens of jackals, and the Jews could not enter. The Jews who resided in the East would come to the city of Ma'azyah (i.e. Tiberias) in order to pray, while those who lived in the West would come to the city of Gaza for that purpose. Those who dwelt in the South would go to the city of Zoar. In the days of the little horn (i.e. the Islamic empire; cf. Dan. 7.8), God opened His gates of mercy to His people, and brought them to His holy city.

Another reference to such pilgrimage in the Byzantine period is found in the commentary of Daniel al-Qūmisī (end of the ninth century) on Daniel 11.32:

Before his arrival (i.e. of the Arabs), they (i.e. the Jews) could not enter Jerusalem and would, therefore, come

\footnotetext{
${ }^{5}$ For the full references see Gil (1996, 165-66).
} 
from the four corners of the earth to Tiberias and to Gaza in order to catch a glimpse of the Temple.

\section{$>$ II.L.0.5.}

The argument here is that the opinion of the community as a whole sanctions the authority of the tradition of the accents. This is similar to the argument of the Karaite al-Qirqisāni that the agreement of the majority of the community ('ijm $\bar{a}$ ) on the biblical reading tradition is the crucial basis of its authority (Khan 1990).

\section{II.L.0.7}

Surely you see that Muslims, whether they be two or more, cannot read with the same degree of coordination as the Jews read, since each one has his own way (of reading). One makes long a place that another makes it short. One reads melodically a place that another reads flat.

The crucial difference between the reading of the Hebrew Bible and the reading of the Qur'ann is that in the former the contour and sequence of pitch accents are fixed by tradition whereas in the latter pitch differences are improvised by individual readers (Nelson 2001).

\section{II.L.0.9.}

הדא אלמכתצר

'this short treatise'

The reference is clearly to the long version of Hidāyat al-Qāri' and not to the short version, in connection with which 'Abū al-Faraj 
also uses the verb ikhtasara 'to shorten' (see the introduction to the short version §II.S.0.1.). The term 'short treatise' in the introduction to the long version can be interpreted as a case of formulaic modesty.

\section{$>$ II.L.1.1.}

The ideas presented in this section correspond closely to the $\mathrm{Mu}^{\text {'t }}$ tazilite views of language, especially those expressed by 'Abd al-Jabbār in his various works. 'Abd al-Jabbār's definitions of speech include 'the arrangement together of two or more letters' (mā intazama min harfayn fa-șācidan), 'what consists of the specific arrangement of these intuitively known letters, occurring in two letters or (more) letters' (mā ḥaṣala fih nizāam makhșūs min hādhih al-ḥurūf al-ma'qūla, hasala fi harfayn 'aw hurūf) and a number of other variant formulations (Peters 1976, 293-94). Likewise 'Abū al-Faraj states that a communicable utterance must consist of a minimum of two letters. Like 'Abd al-Jabbār, 'Abū al-Faraj uses forms of the verb nazama to refer to the arrangement of letters (e.g. §II.L.1.1.4., §II.L.1.1.5, §II.L.1.1.7.). Similar statements are made by the anonymous Karaite grammarian in the work Kitāb al-'Uqūd, viz. 'speech is constituted by articulated sounds arranged in a particular type of arrangement' (al-kalām huwa alhurūf al-muqața'a al-manz̧ūma ḍarb min al-nizāam) (ed. Vidro 2013a, 33), and the works of the Karaite Yūsuf al-Bașīr, e.g. alKitāb al-Muhtawī 'The Comprehensive Book': 'articulated sounds and arranged letters that can by convention convey meaning' ('așwāt muqața'a wa-ḥurūf manẓūma yașihḥ 'an tufid bi-lmuwāḍaca) (Vajda 1974, 61). 
According to 'Abd al-Jabbār, sounds are accidents (i.e. properties) and not substances. He uses the term 'arad to refer to this concept of accident (Peters 1976, 299). This corresponds to the term khāsșiyya, which is used by 'Abū al-Faraj in Hidāyat alQâri' to denote the property of a letter, i.e. its realization in sound. The term khâsșiyya is found in some tajwid manuals to refer to the distinctive phonetic realization of letters or categories of letters, e.g. khhāșșiyyat al-ḥarf al-rakhw ... knhāșșiyyat al-ḥarf alshadid "the distinctive property of a "soft" letter ... the distinctive property of a "strong" letter' in the commentary on al-Dānī's Kitāb al-Taysīr by al-Mālaqī (d. 705/1305), al-Durr al-Nathï w-al'Adhb al-Namir 'Scattered Pearls and Pure Sweet' (ed. Beirut 2002, 183). Al-Dānī uses the corresponding term șifa 'attribute' in his works, e.g. al-Tahdìd fi al-'Itqān w-al-Tajwìd 'The Definition of Precision and Excellent Reading' (ed. Amman 2001, 105).

In Hidāyat al-Qāri' 'Abū al-Faraj occasionally uses the Hebrew term טעם (literally: 'taste') in the sense of the quality of a letter. In §II.L.1.3.3. this occurs in its Arabicized form טעאם ta'ām. The terms are sometimes used together, e.g. טעם אלחרף וכאציתה 'the "taste" of the letter and its property' (§II.L.1.1.2.). The Arabic verb $d h-w-q$ 'to taste' is used in connection with the pronunciation of consonants in §II.L.1.3.8.: פאדא דקת אלחרף פי מחלה אנמא דקת מנה כאציתה 'If you taste a letter (by pronouncing it) in its place of articulation, you will taste its property.' This suggests that טעם 'taste' is used by 'Abū al-Faraj to refer to the perceived quality of the letter, whereas khāșisyya is its intrinsic property.

It is stated in §II.L.1.1.1. and §II.L.1.1.2. that 'the conventional agreement was initially on the property of the letter', i.e. 
the conventional agreement in the primeval speech community was on sounds of letters rather than the names of letters. As remarked, according to 'Abd al-Jabbār sounds were accidental properties and so speech must be an accident too. The conventional agreement was, therefore, initially on speech.

\section{$>$ II.L.1.1.2.}

People differ with regard to the number of the letters that are added to the realization of the letter and its property.

This is referring to the variant forms of the names of the letters that were current during the time of 'Abū al-Faraj.

$>$ II.L.1.1.4.

והם אלמלוך אלדי תסמא אנחא

namely the vowels, which are called vocalization

Two terms are used for vowels. The term 'kings' (mulūk) expresses its hierarchical relationship viz-à-viz shewa, which is referred to as a 'servant' (khādim) in some medieval sources, e.g. the anonymous Masoretic treatise CUL T-S NS 301.84. This would be analogous to the relationship of a conjunctive accent, also referred to in the treatises as a khädim, with a following disjunctive accent. The Arabic term 'anha $\bar{a}$ ' is the plural of nahw, the primary meaning of which is the grammatical inflection of a word. In Arabic such inflection is expressed by case vowels and the term has been extended to all vowels. 
$>$ II.L.1.1.7.

פאדן אלחרף וחדה לא יפאד מנה מעני ועלי הדא אלוגה סמא אלדקדוקיין אלחרף כאדמא אלחרף וחרו

Now, meaning is not expressed by a letter alone and so the Hebrew grammarians have called a 'letter particle' a 'functional particle'.

The word harf is the normal term used for 'grammatical particle' in the standard Arabic grammatical tradition of the period. 'Abu al-Faraj states here that the Hebrew grammarians use the term khādim, which literally means 'serving (particle)', or 'subordinate (particle)', to refer to such grammatical elements. This is the term he himself uses in his grammatical works, e.g. al-Kitāb al-Kāfi (ed. Khan, Gallego and Olszowy 2003, §I.27.1). The designation diqdūqiyyūn is generally used by 'Abū al-Faraj to refer to the Karaite grammarians of Hebrew who preceded him. They practiced a discipline that was known as diqduq 'attention to fine details, careful investigation (of Hebrew Scripture)'. This was associated with the Masoretic activity that produced the early Masoretic treatises. Such activity is sometimes referred to as diqduq ha-miqra 'careful investigation of Hebrew Scripture' in the sources, e.g. Allony (1964). Note also the anonymous JudaeoArabic Masoretic treatise that is preserved in the Genizah fragment CUL T-S D1.2, which states that its source is ממא בינוה what was explained by the early master teachers of the careful investigation of Hebrew Scripture'.

'Abū al-Faraj was sometimes at pains to distinguish his own works from the discipline of diqduq (Khan 1997; 2000b, 1-25). 
One of the reasons for this appears to be that 'Abū al-Faraj believed that his grammatical works al-Kitāb al-Mushtamil and alKitāb al-Kāfi had a universalist approach that dealt not only with Hebrew but with general issues realting to human language, whereas the diqdūqiyyūn were specifically concerned with the Hebrew language of Scripture.

After completing al-Kitāb al-Kāfi, 'Abū al-Faraj wrote a work entitled Kitāb al-Madkhal 'ilā 'Tlm al-Diqdūq fì Ṭuruq al-Lugha al-Ibräniyya 'Book of Introduction into the Discipline of Careful Investigation of the Ways of the Hebrew Language', which he states was intended as a guidebook to the terminology of the diqdūqiyyūn. This work is still unpublished. ${ }^{6}$ In the work 'Abū alFaraj states:

'Speech that is used (for communication) consists of three components: noun (ism), verb (fi $l$ ) and particle (harf, literally: letter), which the people of the discipline of diqduq call 'serving particle' (khādiman). ${ }^{7}$

The manuscript of our passage in Hidāyat al-Qāri' has the reading סמא אלדקדוקיין אלכאדם חרפא the diqduq scholars called a "serving particle" (khādim) a "letter" (harf).' Given the statement in Kitäb al-Madkhal and the following context of the passage in the Hidāya, it is clear that this reading is a scribal error for סמא אלדקדוקיין אלחרף כאדמא.

\footnotetext{
${ }^{6}$ See Khan, Gallego and Olszowy-Schlanger (2003, xiii) for a list of the extant manuscripts.

${ }^{7}$ II Firkovitch, Evr.-Arab. I 4601, fol. 112 (an autograph of 'Abū al-Faraj written in Arabic script): الكلام المستعمل ثلثة اقسام اسم وفعل وحرف يسميه اهل علم

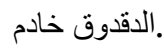


In the published texts of the early Karaite grammarians no specific technical term is attested for 'grammatical particle' (Khan 2000b, 74; 2000a).

\section{פקד אנכתם פי כל לפטה חרף אלף והו מן חרוף אללין}

In each of these words a letter 'alef is hidden, which is one of the soft letters.

This reflects the theory that long vowels were the result of 'soft letters' (hurūf al-linn), i.e. vowel letters. Such a theory was borrowed from the Arabic grammatical tradition and developed more systematically by the Hebrew grammarian Hayyūj, who was active in Spain in the early eleventh century (Basal 2013). Unlike in Arabic, these vowel letters were sometimes elided in the orthography; cf. the discussion in Hidāyat al-Qāri’ in §II.L.1.8.

\section{II.L.1.2.}

וינצאף אלי אלאצול כמסה חרוף והי אלתי יסמונהא פשוטות והם ךֹَוֹףنץ

To the basic letters are added five letters, which are called "straight", namely דסוףץ.

The Hebrew term פִּשּ 'straight' for the long final letters has its origin in Rabbinic literature; cf. Jastrow (1903, 1138).

ינצאף אלי אלאצול איצא סתה חרוף והי בגדذפפת אלטבראניין יזידו עלי

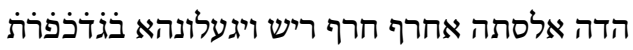

To the basic letters are added six letters, namely בגדכפת. The Tiberians add to these six letters the letter resh, making it (i.e. the group of non-basic letters) בגדכפרת.

The reference here is to the fricative variants of the בגדכפת consonants and the alveolar trill variant of the resh (vol. 1, §I.1.20), 
all of which were regarded by 'Abū al-Faraj as secondary variants of the consonants in question. Sefer Yeșira refers to שבע כפולות בגדכפרת the seven double letters' (Hayman 2004, 24). According to Morag (1960), this is referring to the Babylonian pronunciation tradition, in which there was a variation in the realization of resh that was different in nature from that of the Tiberian tradition. The fricative variants of the בגדכפת consonants were regarded as secondary also in a Masoretic treatise published by Allony and Yeivin (1985, 97).

זאי מכרוך

For the zāa makrūkh see vol. 1, §I.1.7.

\section{$>$ II.L.1.3.2.}

The Hebrew term בית הבליעה 'place of swallowing' is found in Hebrew Masoretic treatises, e.g. $\S 5$ and $\S 6$ in Baer and Strack's (1879) corpus. It is attested already in Rabbinic literature (Jastrow 1903, 173).

For the four cases of dagesh in 'alef in the standard Tiberian tradition see vol. 1, §I.1.1.

\section{$>$ II.L.1.3.3.}

For the meanings of the terms טעם and khässiyya see the comments to §II.L.1.1. above. 
$>$ II.L.1.3.4.

טהור

appearance

Cf. the use of the Arabic term zähir 'appearing' to designate he with mappiq in the Masoretic treatise published by Allony and Yeivin $(1985,97)$.

\section{II.L.1.4.1.}

הי עבאראת תואצע עליהא ארבאבהא ליפהמו אגראצהם לבעצהם בעن

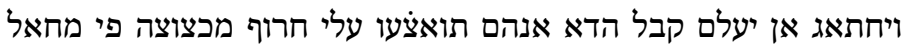

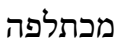

It [i.e. language] consists of expressions that its original speakers established by convention among themselves to make their intentions understood to one another. It needs to be known that before this they established by convention specific letters in various places of articulation.

The expression 'arbābuhā 'its [i.e. language's] masters' is synonymous with 'ahl al-lugha 'the people of the language'.

The establishment by convention of specific letters (hurüf) is referring to the phonetic realization of the letters in the form of the production of sound, as was discussed in §II.L.1.1.

\section{$>$ II.L.1.4.2.}

פעל פי אלנפס

intransitive verb

This term, which literally means, 'action on oneself', is taken from the early Karaite grammatical tradition; cf. the Diqduq of Ibn Nūh (Khan 2000b, 108-11). In the standard Bașran Arabic 
grammatical tradition an intransitive verb was called ficl ghayr muta'addin, which was the term used by 'Abū al-Faraj in his grammar books (Khan, Gallego, and Olszowy-Schlanger 2003, xliii).

\section{II.L.1.4.5.}

ואלקסם אלראבע מא ינבדל מן מחאל מתגאירה והו יעם אלתצחיף

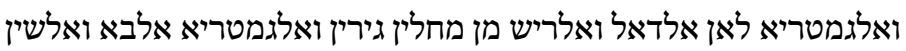
מן מחלין מתגאורין

The fourth category is what interchanges from different places of articulation, which includes scribal error and ciphers, for dalet and resh (which are sometimes confused by scribal error) are from two different places of articulation and the cipher of letters (consisting of the interchange of) bet and shin is from two different places of articulation.

Examples of scribal errors resulting in the interchange of dalet and resh are given in §II.L.1.5.4. They are discussed by 'Abū alFaraj in al-Kitāb al-Kāfi, in which he states 'It is a type of letter interchange arising from a mistake in writing on account of the similarity of two letters' (ed. Khan, Gallego and OlszowySchlanger 2003, §I.28.3.).

The ciphers referred to are in the encryption code known as א"א ב"ש, whereby a letter is exchanged for its counterpart in the opposite place in the alphabet, e.g. 'alef, the first letter in the alphabet, for tav, the last letter, bet, the second letter, for shin, the penultimate, and so forth (Campanini 2013, 638). 
II.L.1.4.7.

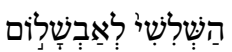

'the third is Absalom' (1 Chron. 3.2).

This is cited by 'Abū al-Faraj as an example of a lamed without meaning also in al-Kitāb al-Kāfi (ed. Khan, Gallego and OlszowySchlanger 2003, §I.25.45.).

II.L.1.4.8.

יקאל אנה מכתצר יוד פי יד ותקדירה בידי

It is said that a yod has been contracted in $T_{\tau}$, and its virtual form is

'Abū al-Faraj uses here the notion of taqdir ('virtual form', 'imagined form'), which he adopted from contemporary Arabic grammatical thought (Levin 1997). This concept is used to explain the existence of various irregularities in grammatical structure. Underlying the actually attested structure of the biblical text, there was a virtual or imagined (muqaddar) structure, which existed in the mind of the author. This imagined structure always conformed to grammatical rules and principles. When the imagined structure deviated from the actually attested structure, it was the imagined structure that constituted the basis of interpretation and translation (Khan 2001, 142-44).

\section{II.L.1.5.}

Some cases of letter interchange that are presented in this section are mentioned by 'Abū al-Faraj in al-Kitāb al-Kāfi, e.g. ed. Khan, 
Gallego and Olszowy Schlanger (2013, §I.26.28, §I.27.34, §I.28.3).

\section{$>$ II.L.1.5.18.}

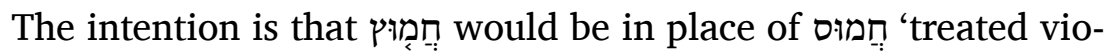
lently (and therefore bloody)'.

\section{II.L.1.5.21.}

ואלמכרת יכון שָתום

The disjoined form would be שָתִָם

'Abū al-Faraj uses the Hebrew terms סִכְרָת 'disjoined' and סָמוּף 'conjoined' alongside the corresponding Arabic terms qat' 'disjoined state' (§II.L.1.4.8.) and mudāaf 'conjoined'. For סָמוּף see §II.L.2.17. These terms are found in Masoretic treatises, e.g. §37 in the corpus of Baer and Strack (1879). In Hidāyat al-Qāri' the terms are generally used in the sense of 'absolute' and 'construct' forms of a noun respectively. In Karaite grammatical literature the terms are used also to denote pausal and context forms (Khan 2007). The term qat $t^{c}$ is used in the sense of pause in Hidāyat alQāri' in §II.L.2.12.14.

ויגב אן יכון אמרה שֶתוֹם או שֶתַם

Its imperative would have to be שִׁתַם or.

For the notion of the imperative as the base of morphological derivation see the comments on §II.L.1.10. below. 


\section{$>$ II.L.1.6.}

The letters אויה are intended here to represent long vowels. This reflects the theory that long vowels were the result of 'soft letters' (hurūf al-līn), i.e. vowel letters; cf. the comments on §II.L.1.1.7. above and the discussion in Hidāyat al-Qāri' in §II.L.1.8.

Some of the material in this section can be found in other Masoretic treatises, such as §29 in the corpus of Baer and Strack (1879), two of the Judaeo-Arabic treatises published by Allony and Yeivin (1985, 99-101, 112), and various fragments of unpublished texts, e.g. CUL T-S D1.2, Mosseri I, 71.1; Oxford Bod. Heb. d 33, fol. 16.

\section{$>$ II.L.1.7.5.}

$$
\text { פהו בתקדיר לחן קבלה ליגרי מגרי הֶוא יבנה־בְית }
$$

so (such cases must be considered) to have a virtual (conjunctive) accent before them in order to conform to

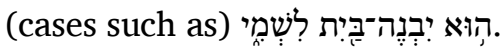

Here 'Abū al-Faraj uses the notion of taqdir 'virtual form', 'imagined form' (see the comment on §II.L.1.4.8. above) to explain an apparent irregularity. The idea is that the conjunctive accent existed in the virtual underlying structure, and so this explained the operation of the 'athe me-rahiq.

\section{II.L.1.7.7 •}

כל ואו פי אכר כלמה יכרג עלי ראי אלשאמיין בבא מרפי

Every $v a v$ at the end of a word is pronounced according to the Palestinians as a bet rafe.

See vol. 1, §I.1.6. for the pronunciation of the Tiberian $v a v$. 
$>$ II.L.1.7.9.

For a possible explanation of the phenomenon described in this section, see vol. 1, §I.3.1.10.

$>$ II.L.1.7.11.

For this feature of the reading of Ben Naftali see Kitāb al-Khilaf (ed. Lipschütz, 1965, 19).

\section{$>$ II.L.1.8.2.}

Yahyā ibn Dā'ūd the Maghribī

This is a reference to the Spanish grammarian Yahyā ibn Dā' $\bar{u} d$ Hayyūj (d. c. 1000).

ולא נכליה אלי אן יגו אהל אללגה פנעלם פאידה מא אצטלחו עליה

and we should not abandon it until the people of the language come and we know the function of what they adopted as their convention.

Since the 'people of the language' are the primeval speech community, this would seem to be tantamount to saying that we should never deviate from the customary reading.

II.L.1.9.2.

For the various degrees of 'heaviness' of tav see vol. 1, §I.3.1.11.3.

$>$ II.L.1.9.3.

For the different realizations of resh, see vol. 1, §I.1.20. 


\section{$>$ II.L.1.10.}

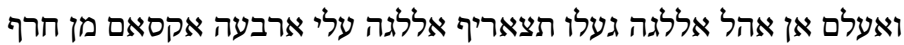

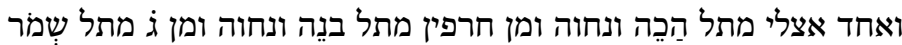

ונחוה ומן ד מתל כרבל ונחוה

Take note that the people of the language made the conjugations of the language in four categories: from one root letter, such as הַכַה 'hit' and the like, from two letters, such as 'build' and the like, from three letters, such as

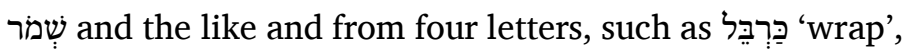
and the like.

According to the medieval Karaite grammarians, the base of the process of the derivation of a word was not an abstract root but rather a concrete structural form consisting of both consonants and vowels. Such a theory of derivational morphology was developed in the early Karaite tradition of grammatical thought in the tenth century, the main extant source for which is the Diqduq of Ibn Nūh. According to Ibn Nūh the imperative form is the derivational base of most verbal forms. The imperative, therefore, was used as the citation form of verbs. This practice of imperative citation forms was continued by 'Abū al-Faraj in his grammatical works and Hidāyat al-Qāri', in which he uses them as lemmata to identify and classify verbal conjugations. This was despite the fact that according to his theory of grammar, adopted from the mainstream Bașran school of Arabic grammar, the infinitive was the base of morphological derivation of verbs; $\mathrm{cf}$. al-Kitāb al-Kāfi (ed. Khan, Gallego, and Olszowy-Schlanger 2003, §II.16.12-15) and Khan (1997). 
Although the Karaite grammarians did not work with a notion of an abstract root that functioned as the source of derivation, they did have a concept of an abstract underlying morphological level, which they referred to as the 'substance' (Arabic jawhar) of a word (Khan 2000b, 74-78). Unlike the morphological base, the substance is not an actual linguistic form that can be pronounced. It consists of a series of letters that are regarded as the core of the word. This is what is referred to in this passage in Hidāyat al-Qāri' as 'root letter' (harf 'aṣlī). Various letters that are present in the morphological base of a word do not belong to the substance and so are not root letters. A final he in a verb is not considered to belong to the substance. The substance of imperative bases such as aִּנָה therefore, are said to consist of two root letters. A prefix such as the he prefix of the hif $i l$ that does not occur in all inflected forms is not considered to be a root letter. The substance of the verb הַכַּה 'hit' was considered to consist of only one root letter. For further details see Khan (2013a; 2013b).

$$
\text { ואלחרף איצא קד תתקלב פי אללפטה ותתגאיר מעאניהא }
$$

A letter may also change position in a word with the result that its meaning changes.

'Abū al-Faraj offers here only one set of examples of such changes of position. In his grammar book al-Kitāb al-Mushtamil (see vol. 1, §I.0.13.4), however, he devotes a long section to this question and presents an inventory of sets of lexical forms that share letters in different sequences (Bacher 1895, 247-49). This is known as an anagrammatical lexical arrangement and is attested in other medieval Jewish sources, in particular Kitāb al-Hāwì 'The 
Book of Collection' of Hai Gaon, which is a complete anagrammatical dictionary of Hebrew (Allony 1969b, 1972).

\section{II.L.1.11.}

The term 'enhancement' (tafkhim) is used by 'Abū al-Faraj to refer to the extension of the basic form of a word or affix by the addition of letters without, in principle, bringing about a change in meaning. The list of examples of added letters includes some additions that we would normally interpret as functional affixes,

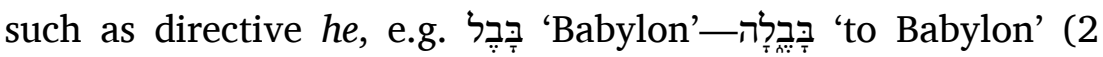

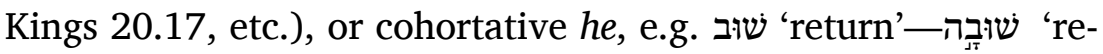
turn' (Num. 10.36, etc.). 'Abū al-Faraj uses the term הא אלתפכים 'he of enhancement' to refer to cohortative he in his grammar book al-Kitāb al-Kāfì (ed. Khan, Gallego and Olszowy-Schlanger 2003, §I.27.126), but does not examine there the phenomenon of enhancement systematically. Saadya Gaon, on the other hand, treats the subject extensively in his grammar Kitāb Fașịh Lughat al-Ibräniyyin 'The Book of the Eloquence of the Language of the Hebrews' (Dotan 1997, 142-45). When, however, 'Abū al-Faraj mentions in Hidāyat al-Qāri' 'somebody who has discussed enhancement' (§II.L.1.11.5., §II.L.1.12.1.), he does not seem to be referring to Saadya, since the cited examples do not correspond to what is extant in Saadya's work.

$>$ II.L.1.11.5.

אלאמר הוֹדֵה הוֹשֵעע

the imperative forms are הiֹשׁِע and añ 
The imperative form was regarded by the early Karaite grammarians as the morphological stem on the basis of which verbal inflections were formed. In his grammar al-Kitāb al-Kāfi, 'Abū alFaraj adopts from the mainstream Bașran tradition of Arabic grammatical thought the notion that the infinitive was the base of derivation (Khan 1997). This Bașran Arabic tradition was merged with the early Karaite tradition in the grammatical works of 'Abū al-Faraj, which sometimes results in apparent inconsistency. He, for example, continued to use the imperative as the citation form of verbs (Khan 2013a). In this passage of Hidāyat al-Qāri' he appears to be working with the early Karaite notion that the imperative was indeed the stem of derivation.

\section{$>$ II.L.1.12.3.}

For the term diqdūqiyyūn 'diqduq scholars' see the comments above on §II.L.1.1.7.

The notion of 'auxiliary letter' (harf musta'mal) is explained by the anonymous Karaite author of Kitāb al-'Uqūd (ed. Vidro 2013a, 51):

An auxiliary letter is established in the entire conjugation. If it is removed, what remains are the letters of the lexical class standing without a clear meaning Examples are the lamed in the lexical class of 'taking', or the nun in the lexical class of 'going away' and in the lexical class of 'approaching', as in נוֹגְנִים , etc. Here there is a clear difference between the removal of the auxiliary lamed and that of het or qof. This holds for each auxiliary 
letter. The difference between its removal and the removal of a root letter is obvious and evident. ${ }^{8}$

I.e. the auxiliary letter is an integral component of the conjugation but elided in some inflections, as is the case with nun and lamed in the cited verbs. This would differ from letters of enhancement, which are added to the basic letters of a conjugation, and so are not integral to it.

\section{$>$ II.L.1.13.}

The 'contraction' ('ikhtișār) is the converse of 'expansion', in that it involves the elision of a letter from the basic form of a word or affix without changing meaning. The basic form is often referred to in this section as the 'virtual form' (taqdir), i.e. the expected regular form (see the comments on §II.L.1.4.8. above). 'Abū alFaraj uses the concept of contraction of letters in al-Kitāb al-Kāfi and, likewise, refers to the uncontracted form as the taqdir of the word, e.g. ed. Khan, Gallego and Olszowy-Schlanger (2003, §I.23.7.). This subject is treated systematically by Saadya in his grammar Kitāb Fașịh Lughat al-'Tbrāniyyīn (Dotan 1997, 140-42).

\section{$>$ II.L.2.2.1.}

In this passage relating to the origin of vowels, 'Abū al-Faraj offers a view of the origin of language that differs from the view

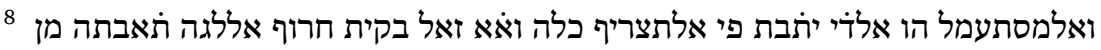

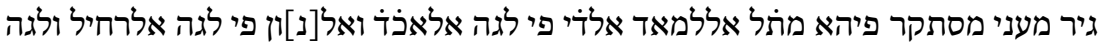

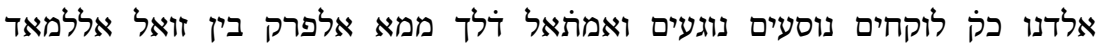

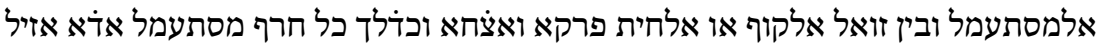

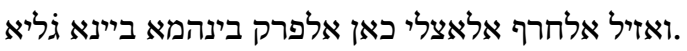


that it has a purely human origin through convention among the primeval speech community known as 'the people of the language' ('ahl al-lugha), which he presents elsewhere in Hidāyat alQāri' and his grammatical works. In the passage he acknowledges that vowels were an integral part of the original conventional establishment of language ('in the original establishment [of language] by convention they [i.e. the vowels] were indispensable'). He then, however, goes on to associate the origin of language with Adam, according to the biblical account of the origin of language:

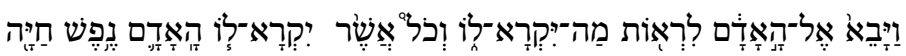

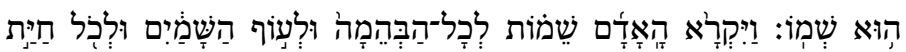

הַשָשָדה

'and He (the Lord) brought them (the animals and birds) to the man to see what he would call them; and whatever the man called every living creature, that was its name. The man gave names to all cattle, and to the birds of the air, and to every beast of the field' (Gen. 2.19-20)

'Abū al-Faraj suggests various ways of interpreting Adam's activity. He and the angels may have established language by convention. This would, in effect, be extending the notion of the primeval speech community ('ahl al-lugha) to a community of Adam and the angels rather than original human speakers alone. Another possibility, says 'Abū al-Faraj, is that the angels taught Adam language. The angels, moreover, would have been taught language by God. The development of language by convention between God and the angels was not possible since such a process requires limbs with which to point to objects and 'Abū al-Faraj, 


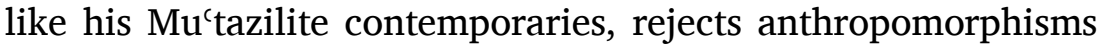
attributed to God such as human-like limbs.

The teaching of language to Adam by angels, who in turn learnt it from God, is a revelationist view of the origin of language. This was adopted by some Muslim theologians and grammarians of the period (Weiss 1974; Loucel 1963). The process of revelatory teaching of language was known in the Islamic tradition as tawqif 'making known' or wahy 'inspiring' and was based

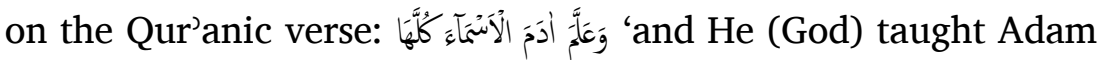
all the names (of things)' (2.31).

The fact that 'Abū al-Faraj presents different versions of the origin of language, conventionalist and revelationist, may have arisen as an attempt to find a synthesis between rationalist

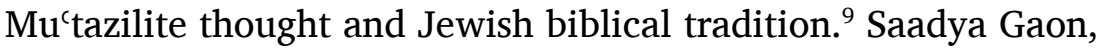
likewise, strove to achieve such a synthesis. Unlike 'Abū al-Faraj, however, Saadya did not attempt this by offering alternative views, but rather presented a hybrid view. According to Saadya a single primeval human, referred to as 'the establisher of the language' (wädici al-lugha), fixed arbitrary names for entities and this fixing was subsequently accepted by consensus ('iștilāh)

\footnotetext{
${ }^{9}$ Maimonides followed an Aristotelian view and regarded Adam's act of naming as indicating by itself that languages are conventional, see Guide of the Perplexed (transl. Pines 1969, 357). By contrast, Jewish exegetes in medieval Europe adopted a revelationist interpretation. Nahmanides, at the height of the 'Maimonidean controversy', explicitly rejected Maimonides' notion of convention; cf. Saenz-Badillos (2004, 297).
} 
among people and transmitted to later generations. The 'establisher of the language' that Saadya had in mind was presumably Adam, but he left the name unspecified, possibly to make his theory more universalist and applicable to all human language. According to Saadya, God did not create language but gave Adam the faculty of language (Dotan 1995; 1997, 96-104).

It is also possible that ' $\mathrm{Abu}$ al-Faraj was influenced by some streams of Muslim thought in the eleventh century that attempted a synthesis of the revelationist and conventionalist views (associated with the scholar 'Abū 'Isḥāq al-'Asfarā'īnī, d. 1027) or were non-committal and held that neither view could be argued conclusively (associated with the scholar 'Abū al-Bakr al-Bāqillānī, d. 1013) (Weiss 1974).

\section{II.L.2.3.2.}

ללערב פי לגתהם מן אלאעראב תלתה והי אלרפע והו אלצמה מן פוק

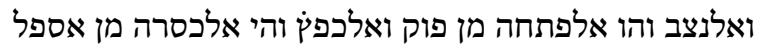

The Arabs have three inflectional vowels in their language. These are 'raising' ( $r a f$ '), i.e. the vowel damma, which is written above; 'holding level' (nașb), i.e. the fatha vowel, which is written above; and 'lowering' (khafd), i.e. the vowel kasra, which is written below.

The terms rafc 'raising', naṣb 'holding level' and khafḍ 'lowering' derive from a theory of the production of vowels originating in Arabic grammatical thought that involves both the position of buccal organs and the direction of the dynamic flow of air. It was adopted also by Saadya (Dotan 1997, 113-26) and is found in a Hebrew Masoretic treatise published by Baer and Strack (1879, $\S 36)$, see Eldar (1983) and Posegay (2020). In this section of 
Hidāyat al-Qāri' 'Abū al-Faraj is referring to the vowels of Arabic case inflections, which mark syntactic relations. In §II.L.2.4.§II.L.2.8. he transfers this terminology to categorize Hebrew vowels in morphological patterns. The seven Hebrew vowels are assigned to the three Arabic categories as follows: rafc (holem, shureq), nașb (patah, segol, qameș), khaf̣̣ (șere, hireq). A similar practice of applying this three-way classification of vowels to Hebrew morphology is found in the Masoretic treatise $\S 36$ of the corpus of Baer and Strack (1879).

\section{$>$ II.L.2.4.}

ואלנצב ידכל תחתה ג נגמאת אלפתחה אלכברי והי אַ ואלפתחה אלוסטי

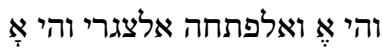

Three vowels correspond to (the Arabic inflectional vowel) 'holding level' (nașb), namely 'big fatha', i.e. ֵ, 'medium fatha', i.e. N, and 'small fatha', i.e. ș.

In early Masoretic terminology a basic distinction was made between patah (open vowel) and qames (vowel with lip-tightening). The vowel segol was associated with patah and referred to as patah qațan 'small patah'. The vowel șere was associated with qameș and referred to as qameș qațan 'small qameș', see vol. 1, §I.2.1.5. Here in Hidāyat al-Qāri' a different grouping of the vowels is made based on the perceived proximity of the Hebrew vowels to each of the three Arabic vowels. In the early Masoretic terms patah qațan and qames qațan, the attribute 'small' relates to the notion that these vowels were in some way more attenuated and less open than prototypical patah and qames. This notion can be traced back to Syriac grammatical sources where the Syriac 
term qațin 'narrow' is used to describe the higher front vowels (Posegay 2020). The terms 'big fatha', 'medium fatha' and 'small fatha' seem to relate to varying degrees of lip-spreading. The vowel patah was pronounced with the maximal degree of lipspreading and qames with the lowest degree, with segol exhibiting an intermediate lip position. The same attributes are used in §II.L.2.7. and applied to the term naṣb, viz. 'big naṣb' for patah. and 'small naṣb' for qames.

\section{$>$ II.L.2.5.}

אלי גיר דלך ממא קד אסתעמל פי אלאמר ואלעבר מתל שוֹרֵּף שוֹרַף

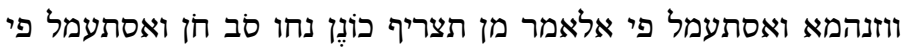
אלעבר מן תצריף שירו נחו נוֹדַע נוֹשֵע מוֹע

To these should be added forms that are used for the imperative and the past such as שטוֹרֵר 'be burnt', שטרף 'was burnt', and other examples of this pattern; those that are

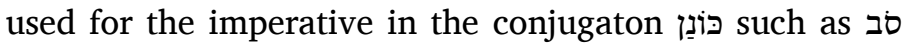
'turn', חi 'be gracious'; those that are used for the past in the conjugation נִירוֹ, such as נוֹשֵעע 'be known', saved'.

The Karaite grammarians regarded the imperative form to be the morphological base of most verbal forms (see comments on §II.L.1.10. above). This morphological base enshrined the core structural features of the inflected forms derived from it. Although the imperative base is a concrete linguistic form, it is not necessarily a form that is attested in the corpus of Biblical Hebrew. The Karaite grammarians held that it is crucial that there is a close structural relationship between the base and the inflected form. If there is no attested imperative that is deemed 
sufficiently close in structure to the inflected form, a common way of resolving this problem is to propose a hypothetical imperative base.

The imperative base always belongs to the same pattern (binyan) as the verbal form derived from it. The notion of pattern (binyan) as a unitary abstract category, however, is not found in the morphological theory of the Karaite grammarians. Imperative bases were classified together in groups not on account of sharing of abstract stems but on account of their sharing of actual structural patterns. The imperative form oְִּּ 'write', for instance, was said to have the same pattern as imperatives such as שִממר 'guard' and שִּר 'harvest'. The imperative שִּר 'return' was said to have

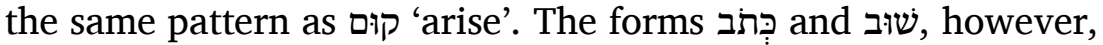
were not classified together on a more abstract structural level, as became the custom in Hebrew grammar following the teachings of Hayyūj.

As remarked, the imperative base had to have a maximally close structural resemblance to the form derived from it. In order to achieve this in some cases the imperative form that is posited as the base of an inflected verb does not actually occur in the

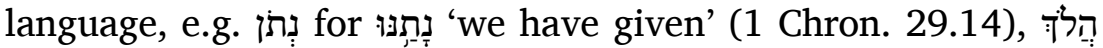

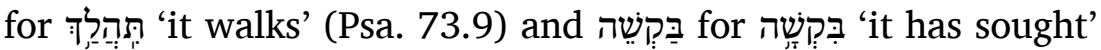
(Ecc. 7.28). The motivation for positing an imperative base such

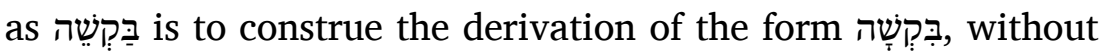
the dagesh in the qof, as fully regular and not an anomalous inflection of the imperative base Such hypothetical imperatives were not used for the writing of creative literature. Indeed, no Karaite author has been found who 
used these postulated forms in a creative Hebrew text. This reflects the fact that the proposed imperative base of a verb was intended as a purely structural source of derivation. Further evidence for this is that even passive forms expressed by morphological patterns that we now call the $p u^{\prime} a l$ and $h u f^{\prime} a l / h o f^{\prime} a l$ are regarded by the Karaite grammarians as derived from imperative bases, which cannot be naturally functional in

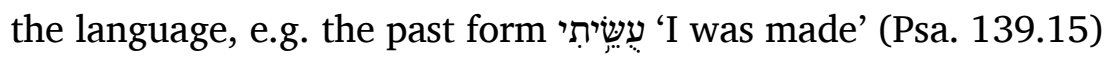
is said to be derived from the imperative form עִגֶֶׁה. Here in §II.L.2.5. of Hidayat al-Qāri' the past form 'was burnt'

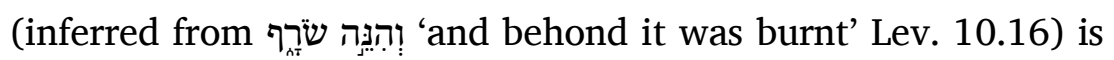
cited alongside the imperative שنרי 'be burnt', which would have been considered to exist hypothetically as its morphological base. Passive imperative bases of $p u^{\prime} a l$ and $h u f^{\prime} a l / h o f^{\prime} a l$ patterns have șere in their second syllable by analogy with active pi $^{`} e l$ and $h i f^{\prime} i l$ imperatives. For more details see Khan (2000b, 41-45; 2013a; 2013b).

'Abū al-Faraj uses mnemonic symbols to arrange the imperative bases of verbal conjugations into classes. Such a classification is presented systematically in \$I.22 of al-Kitāb al$K \bar{a} f \bar{i}$ (ed. Khan, Gallego and Olszowy-Schlanger 2003). These symbols, known in Arabic as 'alāma or ribāt and in Hebrew as סימן, consisted of bisyllabic Hebrew words in which the first vowel corresponds to the vowel common to all imperatives and the last vowel to the vowel common to all past forms in the class. The vowels in question may be those of the first syllable of the imperative and past forms or those of the last syllable of these forms (Vidro 2013b, 652). The conjugations of the imperatives 


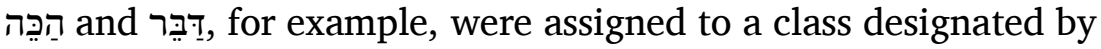
the mnemonic symbol which was based on the first vowel of

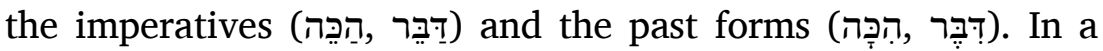
similar way the symbol שִירָה included conjugations with

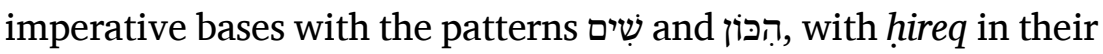
initial syllable and qames in the initial syllable of their past forms,

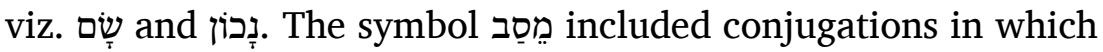
the imperative had a sere in the final syllable and the past had a

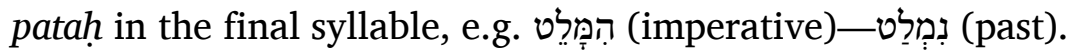

This system of classification originated in the early Karaite tradition and was developed by 'Abū al-Faraj. It was subsequently elaborated still further in some other Karaite works, such as the anonymous treatises Kitāb al-'Uqūd (Vidro 2011; 2013a) and Me'or 'Ayin (Zislin 1990). The classification of verbal conjugations and the systematization of rules for their derivation that are found in these works are likely to have had a pedagogical motivation (Vidro 2011, 165-79).

Just as hypothetical imperative bases were posited for cer-

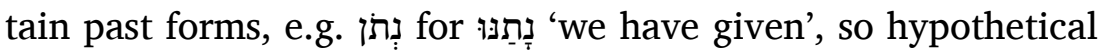
past forms were in some cases posited for attested imperative forms. This applies, for example, to the first in the class of conjugations represented by the symbol כַּּּ, which is mentioned in §II.L.2.5. of Hidāyat al-Qāri'-in the manuscript used in the edition for this passage the original patah has been replaced by segol due to interference from Arabic phonology on the scribe, viz. כּנֶן (cf. vol. 1, §I.4.3.3.). In conjugations represented by the symbol כiּ the first vowel of the imperative is holem and the first vowel of the past form is patah. The imperatives of the class כּוֹנֵ that are 
given in §II.L.2.5. are סב 'דן 'turn' and gracious'. The attested

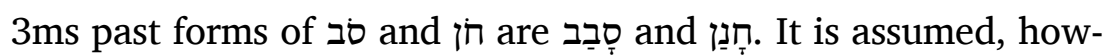
סַב ever, that these imperatives have hypothetical 3ms past forms and ${ }_{i}$ in which the first vowel is patah, in conformity with the symbol Gallego and Olszowy-Schlanger 2003, §I.22.19) and Kitāb al'Uqūd (ed. Vidro 2013a, 167). The forms סַב an were inferred from attested inflected forms such as סַذָּתי 'I have turned' (1 Sam.

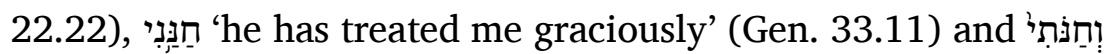
'and I shall be gracious' (Exod. 22.19).

The other symbol mentioned in §II.L.2.5. is שִירו, which is

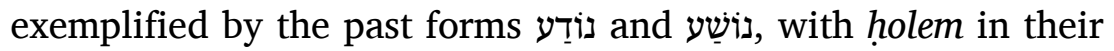
first syllable. The imperative forms of these are הִוּשָע with hireq in their first syllable. Full details and vocalization are given in al-Kitāb al-Kafi (ed. Khan, Gallego and OlszowySchlanger 2003, §I.22.25) and Kitāb al-' $U q u \bar{u}$ (ed. Vidro 2013a, 193).

פקד צאר הדא אלקסם אלואחד יסתעמל פי אלפאעלין כמא אסתעמלו

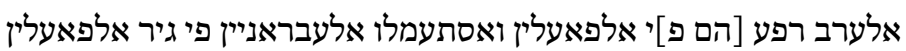

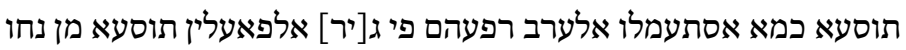

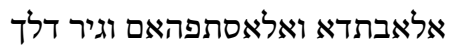
This category (of $r a f$ ) is used for agents, just as the Arabs use raf' for agents. The Hebrews use it for forms other than those designating agents by extension, just as the Arabs use their $\mathrm{raf}^{\prime}$ for forms other than those designating agents by extension, such as initial positioning (of nominal subjects), interrogative constructions, and so forth. 
In this passage 'Abū al-Faraj identifies a correspondence between the use of the Arabic and Hebrew raf ${ }^{c}$ in their marking of agents. In the case of Arabic, the $r a f^{`}$ vowel $-u$ is a case-vowel marking the agent of the clause and so plays a syntactic role. In Hebrew, by contrast, the use of the raf' vowel holem plays a morphological role as an element in the morphological pattern of Hebrew agents, e.g. הררג 'slayer'. According to 'Abū al-Faraj the use of hִolem in Hebrew in other morphological patterns is by a process of extension that is analogous to the extension of the raf' case-vowel $-u$ in Arabic to items that are not agents, including the subject of nominal (i.e. verbless) clauses and interrogative constructions. The latter is most likely referring to nominal clauses with initial interrogative particles such as hal al-'amiru fi al-bayti? 'Is the commander in the house?', in which the item with the - $u$ case vowel is not the initial item (mubtada').

\section{$>$ II.L.2.6.}

The symbol שׁוּעָ includes conjugations in which the first vowel of the imperative is shureq and the first vowel of the past form is

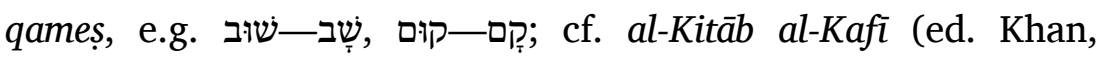
Gallego and Olszowy-Schlanger 2003, §I.22.18) and Kitāb al'Uqūd (ed. Vidro 2013a, 161-65).

\section{II.L.2.7.1.}

אלמפעול אלמטלק והו אלמצדר נחו שָממר זָכר בָנה עָשׁה ואמתאל דלך

It is used in the 'absolute patient', i.e the infinitive, as in

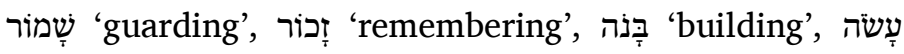
'doing', and the like. 
The Arabic 'absolute patient' (maf'ūl muṭlaq) is a verbal noun in the accusative case in constructions such as daraba darban 'he struck a striking', sāra sayran 'he journeyed a journey'. This has the role of an 'inner object', i.e. a syntactic object that does not express the role of the undergoer of the action expressed by the verb but rather the action itself. In al-Kitāb al-Kāfi (ed. Khan, Gallego, and Olszowy-Schlanger 2003, §I.21.2.) the Arabic maf' $\bar{u} l$ muțlaq is equated by 'Abū al-Faraj with the Hebrew infinitive. He cites examples there of both the infinitive absolute and also the infinitive construct, which he did not distinguish as separate forms as we do today. In this passage in Hidāyat al-Qāri’ the Hebrew examples are infinitive absolutes.

\section{$>$ II.L.2.7.2.}

The symbol represents conjugations that have imperatives with patah in their first syllable and past forms with hireq in their first syllable. This clearly applies to the first two examples cited,

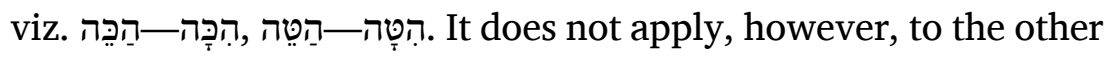

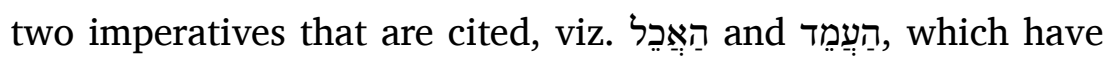

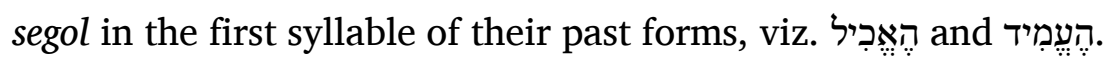
For this reason the author of Kitāb al-'Uqūd classified the last two verbal conjugations under the symbol מַכֶּ (ed. Vidro 2013a,

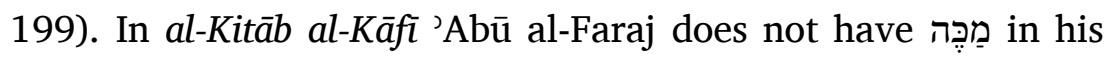
inventory of symbols. In §I.22.10. of al-Kitāb al-Kāfì he includes

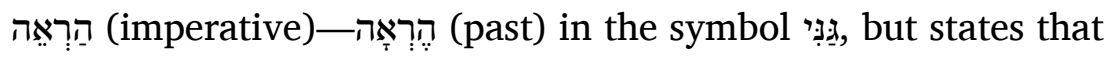
the past form 'does not have a hireq on account of the resh.' He

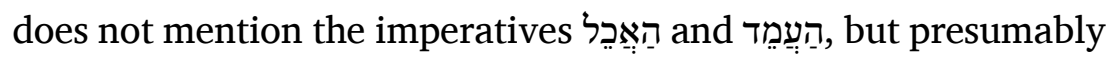
he would have included them in 
in the same way as הַרְאה and explain the segol as a change conditioned by the initial guttural.

$$
\text { אלמצאדר אלמסתעארה נחו דבר קְּּה לשלום }
$$

'transposed infinitives', such as "(we)

look for peace' (Jer. 8.15, etc.)

'Transposed infinitives' (mașādir musta'āra) are infinitives whose form originally belongs to a different category, in this case that of an imperative, but has been extended to the function of an infinitive. This type of infinitive is discussed in Kitāb al-'Uqūd (ed. Vidro 2011, 303).

\section{II.L.2.8.2.}

The inventory that is given here of past forms in the class of conjugations represented by the symbol (i.e. conjugations with imperatives with patah in their first syllable and with past forms with hireq in their first syllable; cf. the comments on §II.L.2.7.2., $\S I I . L .2 .5$. above) is longer than the one given by 'Abu al-Faraj in the section on in al-Kitāb al-Kāfĩ (ed. Khan, Gallego and Olszowy-Schlanger 2003, §I.22.6.-§I.22.13.). It does, however, correspond closely to the fuller inventory of conjugations of is found in Kitāb al-' $U q u \bar{u} d$ (ed. Vidro 2103, 96-151). Some of these are hypothetical past forms that require comment.

The list here in Hidāyat al-Qāri' includes the two forms

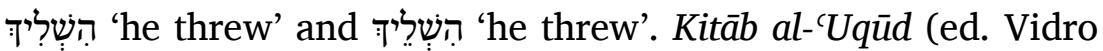
2013a, 128-130) distinguishes between the two conjugations

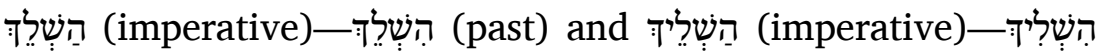
(past). The first lacks a yod in both imperative and past whereas 
the second has a yod in both forms. The purpose of distinguishing the two conjugations was to account for the lack of yod in the

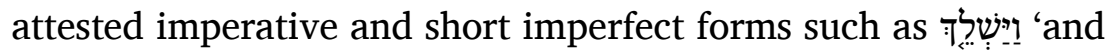
he cast' (Jud. 9.17) versus the presence of yod in other inflections

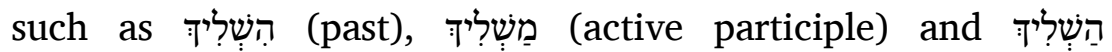
(infinitive). In the first conjugation the past form is hypothetical (הּשְׁלָּ) whereas in the second conjugation the imperative is hypothetical (הַשְֶׁליך with yod). Our passage in Hidāyat al-Qāri’ has

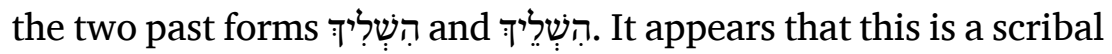
error in the extant manuscripts and this should read הִשְׁליך: and הָשְׁלֶּ (without yod).

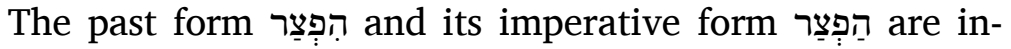

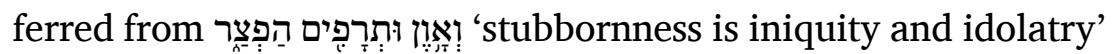
(1 Sam. 15.23); cf. Kitāb al-'Uqūd (ed. Vidro 2013a, 131), Ibn Nūh, Diqduq (ed. Khan 2000b, 370-71).

The past form בִּקְשָָׁה 'he sought' and its imperative form

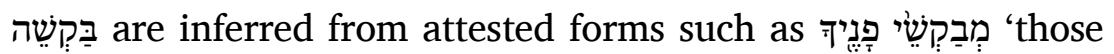
who seek your face" (Psa. 24.6), which does not have dagesh in the qof; cf. Kitāb al-'Uqūd (ed. Vidro 2013a, 138-141), Ibn Nūh, Diqduq (ed. Khan 2000b, 61) and an early anonymous Karaite treatise (ed. Khan 2000a, 106-15).

The past form הדִרְכָה 'he bent (a bow)' and its imperative

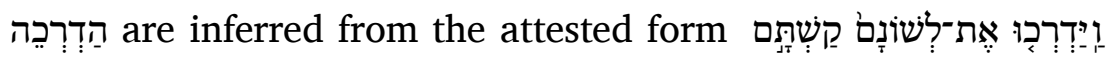
שֶׁקֶר 'and they bent their tongue like their bow in falsehood' (Jer. 9.2); cf. Kitāb al-'Uqūd (ed. Vidro 2013a, 138-139).

Conjugations represented by the symbol שִירָ contain a hireq in the first syllable of their imperative form and a qames in the first syllable of their past form (al-Kitāb al-Kāfi, ed. Khan, 
Gallego and Olszowy-Schlanger 2003, §I.22.20.-§I.22.24.; Kitāb al-'Uqūd, ed. Vidro 2013a, 172-189, Me'or 'Ayin ed. Zislin 1990,

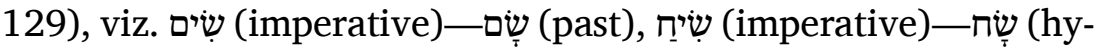

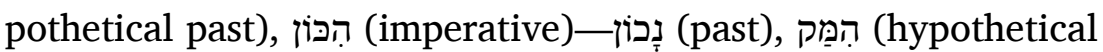

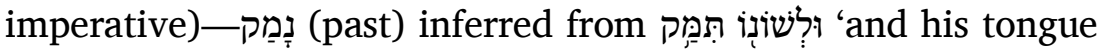

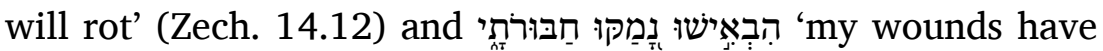
grown foul and have festered' (Psa. 38.6), הבוּך (hypothetical im-

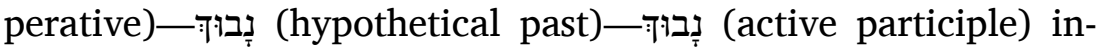

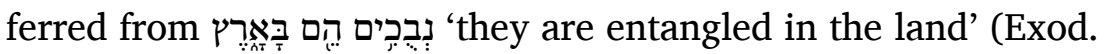
14.3). The imperative form הסiס, which is given in this section in Hidāyat al-Qāri' as an imperative of the symbol שִירָ, does not appear in the lists of conjugations in the Karaite grammatical texts and it is not clear from what attested forms it could be inferred. The lists offer other imperatives that are close in form,

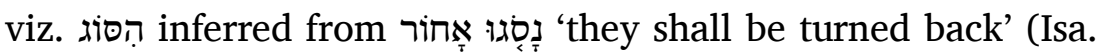

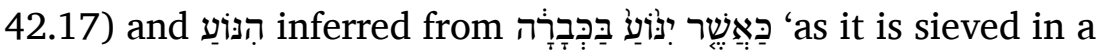
sieve' (Amos 9.9) (Kitāb al-'Uqūd ed. Vidro 2013a, 180-183). It is possible that הסוֹע is a scribal conflation of these two forms.

The symbol מֵסֵב included conjugations that had șere in the final syllable of the imperative and patah in the final syllable of the past form (al-Kitāb al-Kāfì, ed. Khan, Gallego and OlszowySchlanger 2003, §I.22.36; Kitāb al-'Uqūd, ed. Vidro 2013a, 22042; Me'or 'Ayin, ed. Zislin 1990, 135-36). The patah in the hypo-

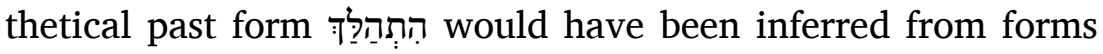
such as הִתְהַלַכְתִתי 'I walked' (Gen. 24.40). 
$>$ II.L.2.10.2.

פצאר אלחרף אלדי תחתה אלשוא סאכנא לא יתחרך בתה מהמא הוא תחתה ופצלה ממא בעדה ואצאפה אלי מא קבלה סלו סלה יתות

Whatever letter it occurs under is not mobile at all and it (the quiescent shewa) cuts it off from what is after it and conjoins it to what is before it.

For this function of silent shewa see vol. 1, §I.2.5.2.

\section{II.L.2.12.}

Some of the material in this section on the mobile shewa has parallels in earlier Masoretic treatises such as $§ 11-\S 15$ of Baer and Strack's (1879) corpus, Diqduqe ha-Ṭe'mim (ed. Dotan 1967, §5, $\S 14)$ and the Treatise on the Shewa (ed. Levy 1936).

\section{II.L.2.12.1.1.}

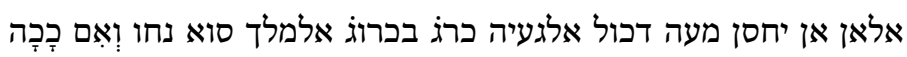

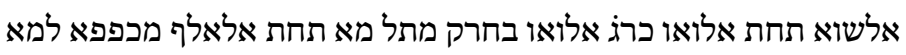
לם תכון מעה אלגעיה אלואו כרות

Now, if it is appropriate for $g a^{c} y a$ to occur on it, it is pronounced equal to the vowel (following it), for example,

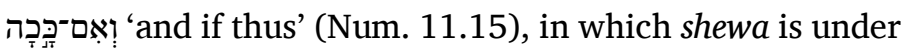
$v a v$ and the $v a v$ is pronounced with hireq like that which is under the 'alef, but shortened since it it does not have gacya.

The argument here is that a shewa with a gacya behaves like a full vowel and so would be long in an open syllable. 
$>$ II.L.2.12.2.1.

פשוא אלד חרוף מקצור עלי מא קבלה ושוא אליוד גיר מקצור עלי מא

בעדה

The shewa of the four letters is restricted by what is before it, but the shewa of yod is not restricted by what is after it.

The intention here seems to be as follows. When a shewa is followed by a guttural consonant, its realization is determined by whether or not it is preceded by a guttural consonant. The realization of shewa before yod, however, is not affected by the vowel that follows the yod.

\section{$>$ II.L.2.12.3.3.}

אין אב ללגעיה

The gacya has no principle.

In modern terminology this is tantamount to saying that the ga $y a$ has no phonological function but is only an optional phonetic phenomenon. This applies to cases where, according to the discussion in this passage, the reader has a choice as to whether to pronounce ga'ya or not. It would not apply to cases such as

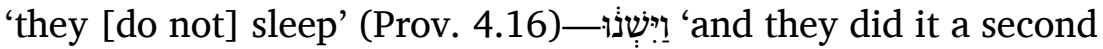
time' (1 Kings 18.34), where the ga'ya is obligatory.

\section{$>$ II.L.2.12.5.}

פאן תם אלף מסתעאר פאדא קלת שְתַַים שְתֵי צאר אלשוא סאכן For if there is an added 'alef and you say [?e $\int^{1} \mathrm{t}^{\mathrm{h}} \mathrm{a}$ :jim] and

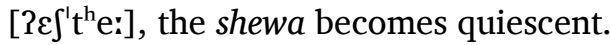


In the available manuscripts, the prosthetic 'alef is not written. It is explicitly written in discussions of this topic in some other Masoretic treatises, e.g. Treatise on the Shewa and the other sources discussed by Levy (1936, 31-33).

\section{II.L.2.12.6.}

Parallels to this section are found in $\S 14$ of Baer and Strack's (1879) corpus of Masoretic treatises and in Kitāb al-Musawwitāt (ed. Allony 1963, 146; 1983, 116).

For the hatef qames in the closed syllable of 'drag her!' (Ezek. 32.20) see vol. 1, §I.2.5.1.

\section{II.L.2.12.9.}

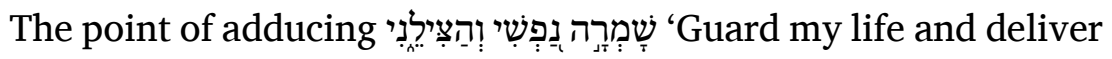

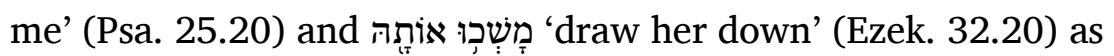
an objection seems to be that in some manuscripts the short

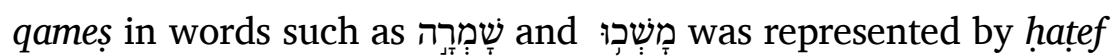
qames, and this could be construed as a mobile shewa, which would be followed by quiescence in the following letter. The response is referring to standard Tiberian vocalization, in which the shortness is not represented by using a hatef qames in a closed syllable, but there is reliance only on the oral tradition.

\section{$>$ II.L.2.12.10.}

The argument of this subsection complements that of the ninth subsection. The claim is that a mobile shewa has to be followed 
by a vowel and then, on the third letter, a quiescent shewa may occur.

\section{$>$ II.L.2.13.1.}

See vol. 1, §I.2.5.8.1.

\section{$>$ II.L.2.13.2.}

For an explanation for the reading of the shewa as silent in the six words that deviate from this rule, see vol. 1, §I.2.5.7.3.

\section{$>$ II.L.2.13.3.}

For the distribution of vocalic shewa after conjunctive vav, see vol. 1, §I.2.5.8.4.

\section{$>$ II.L.2.15.}

For the theory of vowel production described in this section, see vol. 1, §I.2.1.3.

\section{$>$ II.L.2.16.}

In the Karaite grammatical works the term 'arad is normally used to designate a noun referring to an abstract quality that is an attribute of an entity, e.g. Ibn Nūḥ, Diqduq (ed. Khan 2000b, 238):

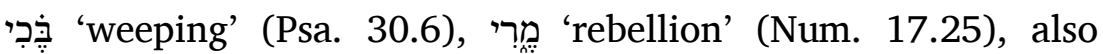
al-Kitāb al-Kāfi (ed. Khan, Gallego and Olszowy-Schlanger 2003, xliv). Here the concept of ' $a r a d$ has been extended to include also finite verbs. 


\section{II.L.2.17.}

This section is an analysis of the differences between vowels within the framework of the theory of the production of vowels that is adopted elsewhere in Hidāyat al-Qāri', see comments on §II.L.2.3. above.

$>$ II.L.3.2.1.

Cf. $\S 44$ in the Masoretic corpus published by Baer and Strack (1879).

$>$ II.L.3.2.3.

Cf. $\S 56$ in the Masoretic corpus published by Baer and Strack (1879).

ורבאטהא אקלקני אלעבד כשית אלוגע קתלתה

Their mnemonic combination is 'The slave has vexed me;

I have feared pain; I have killed him'.

For such mnemonic devices see Vidro (2013b).

$>$ II.L.3.2.4.

Cf. $\S 40$ and $\S 72$ in the Masoretic corpus published by Baer and Strack (1879); Seder ha-Simanim (Allony 1965, כז־כח) and Kitāb al-Musawwitāt (Allony 1963, 148-50; 1983, 106-9). See also vol. 1, §I.2.11. 


\section{II.L.3.2.5.}

Cf. Diqduqe ha-Te $e^{`}$ amim (ed. Dotan 1967, §7). For the exceptional cases see the discussion in vol. 1, §I.2.3.2., §I.2.11.

II.L.3.2.6.

Cf. Diqduqe ha-Te'amim (ed. Dotan 1967, §8). For the exceptional cases see the discussion in vol. 1, §I.2.3.2., §I.2.11.

II.L.3.2.7

Cf. Diqduqe ha-Ṭe amim (ed. Dotan 1967, §21). Cf. vol. 1, $\S I$ 2.5.7.5.

\section{SHORT VERSION}

\section{$>$ II.S.0.0.}

The short version begins with an authorial introduction, in which 'Abū al-Faraj states that he has been requested to compose a short version of the longer work. As remarked in the comments above on the introduction to the long version, such an indication of a 'request to compose' was a standard component of introductions to Arabic works of the period and may have been fictitious, especially when, as is the case here, the requester remains anonymous.

\section{$>$ II.S.1.7.}

In this section 'Abū al-Faraj adds a comment on the phenomenon that he discussed a length in §II.L.1.5. of the long version. He 
indicates that he now prefers not to refer to the phenomenon as 'interchange' (tabdil), since it is possible that the change of letters in the forms in question expresses semantic modification.

\section{$>$ II.S.2.9.}

The one exception that breaks this rule is אִדנָי בָם 'the Lord in them' (Psa. 68.18); cf. long version, §II.L.1.7.8.

\section{II.S.4.2.}

For this notion of the vowels being realizations of 'soft' letters $\aleph$, ה, ו, and ' see vol. 1, §I.2.1.8.

\section{II.S.5.6.}

ואעלם אן אלשוא אלמתחרך לא יקע פי אלחרף אלתאני לה סכון בתה לאנה יתחרך לאגל חרכת אלאול באלשוא

Take note that a mobile shewa never occurs on a second letter (of a word) that has a silent (following letter), because it (this second letter) is mobile due to the mobility of the first letter with shewa.

I.e. if the first letter of a word has shewa, which must be mobile, the second letter cannot have a mobile shewa. This second letter has a vowel and this is followed by a silent letter, which is either a normal consonant, e.g. לְכְרִמִ or a 'soft' letter inside a long vowel (see short version §II.S.4.2.), e.g. לִכוּ.

\section{$>$ II.S.5.7.}

Both the qames and the stressed patah of the cited words were pronounced long, so, according to the theory of 'soft' letters (cf. 
short version §II.S.4.2.), they contained an 'alef, although this does not appear in the orthography.

\section{$>$ II.S.6.11.}

The argument here seems to be that a mobile shewa is dependent on a mobile letter with a vowel, which, therefore, obligatorily follows a mobile shewa. A mobile shewa cannot be dependent on another mobile shewa. A quiescent shewa can come after a sequence of mobile shewa and a letter with a vowel, but not immediately after the initial mobile shewa. 


\title{
REFERENCES AND ABBREVIATIONS
}

\author{
AbBreviations \\ Bod. = Bodleian Library, University of Oxford \\ CUL $=$ Cambridge University Library \\ $\mathrm{JRL}=$ John Rylands Library, University of Manchester \\ NLR $=$ National Library of Russia, St. Petersburg
}

\section{REFERENCES}

'Abd al-Wāḥid ibn Muḥammad ibn 'Abī al-Saddād al-Mālaqī. 2002. الدر النثير و العذب النمير. Edited by 'Ādil 'Ahmad 'Abd alMawjūd, 'Alī Muḥammad Mứcawwạ̣ and 'Aḥmad 'Īsā alMa'ṣarāwī. Beirut: Dār al-Kutub al-'Tlmiyya.

'Abū 'Amr 'Uthmān ibn Sa'īd al-Dānī. 2001. التحديد فى الاتقان و التجويد. Edited by Ghānim Qaddūrī al-Ḥamad. Amman: Dār 'Ammār.

Allen, W. Sidney. 1948. 'Ancient Ideas on the Origin and Development of Language'. Transactions of the Philological Society, 35-60.

ספר הקולות-כתאב אלמצותאת למשה בן' . אשר'. Lěšonénu 29: 9-23, 136-59.

-1964. 'רשימת מונחים קראית מהמאה השמינית'. In ספר קורנגרין, edited by Asher Weiser and Ben-Zion Luria, 324-63. TelAviv: Niv.

—. 1965. 'סדר הסימנים'. Hebrew Union College Annual 35: 1-40 (Hebrew section). 
- 1969a. Ha-'Egron Kitāb 'Ușūl al-Shi'r al-Ibrānī by Rav Sě $a d y a$ Ga'on. Critical Edition with Introduction and Commentary. Jerusalem: Academy of the Hebrew Language (in Hebrew).

-1969b. 'השיטה האנאגרמטית של המילונוּת העברית בספר יצירה'. Proceedings of the World Congress of Jewish Studies 5: 12729.

- השיטה האנאגרמטית של המילונוּת העברית בס' יצירה' .1972. Temirin 1: 63-99.

- שתי רשימות ספרים לרושם אחד במאה ה־13'. Alei Sefer 1: 35-58.

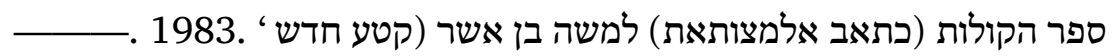
מגניזות קהיר-כיכי"ב)'. Lěšonénu 47: 85-124.

Allony, Nehemiah, and Israel Yeivin. 1985. מספרוּת הקוֹלוֹת (אלמצותאת)'. Lěšonénu 48-49: 85-117.

Bacher, Wilhelm. 1895. 'Le Grammairien Anonyme de Jérusalem'. Revue des Études Juives 30: 232-56.

Baer, Seligmann, and Hermann Leberecht Strack. 1879. Dikduke Ha-Téamim. Leipzig: L. Pernoy.

Basal, Nasir. 1998. "החק הראשון של "אלכתאב אלמשתמל" לאבו אלפרג' 'הרון ותלותו ב"כתאב אלאצול פי אלנחו" לאבן אלסראג'. Lešonénu 61: 191-209.

__ 1999. 'The Concept of Hāl in the al-Kitāb al Muštamil of Abū al-Farağ Hārūn in Comparison with Ibn al-Sarrāğ'. Israel Oriental Studies 19: 391-408.

—_. 2013. 'Latent Quiescent (Sākin Layyin)'. In Encyclopedia of Hebrew Language and Linguistics, edited by Geoffrey Khan, 
Shmuel Bolozky, Steven E. Fassberg, Gary A. Rendsburg, Aaron D. Rubin, Ora R. Schwartzwald, and Tamar Zewi, 2:484-90. Leiden-Boston: Brill.

Becker, Dan. 1996. 'A Unique Semantic Classification of the Hebrew Verb Taken by the Qaraite 'Abū Al-Faraj Hārūn from the Arab Grammarian 'Ibn al-Sarrāj'. Jerusalem Studies in Arabic and Islam 20: 237-59.

Campanini, Saverio. 2013. 'Cryptography'. In Encyclopedia of Hebrew Language and Linguistics, edited by Geoffrey Khan, Shmuel Bolozky, Steven E. Fassberg, Gary A. Rendsburg, Aaron Rubin, Ora R. Schwartzwald, and Tamar Zewi, 1:636-40. Leiden-Boston: Brill.

Dotan, Aron. 1967. The Diqduqé Hatțěcamim of Ahăron Ben Moše Ben Ašér. Jerusalem: The Academy of the Hebrew Language (in Hebrew).

- 1995. 'Particularism and Universalism in the Linguistic Theory of Saadia Gaon'. Sefarad 51: 61-76.

- 1997. Dawn of Hebrew Linguistics: The Book of Elegance of the Language of the Hebrews. Jerusalem: ha-Iggud ha-'Olami le-Mada'e ha-Yahadut.

Eldar, Ilan. 1980. ' שער בדבבר מקומוֹת החיתוּך של העיצוּרים מתוֹך הדאיה אלקאר הארוֹך. Lěšonénu 45: 233-59.

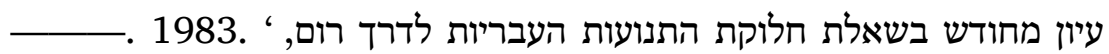
מחקרי לשון: מוגשים לזאב בן־חיים בהגיעו דרך מטה ודרך ניצב לשיבה, edited by Moshe Bar-Asher et al., 43-55. Jerusalem: Magnes. 
"מכתצר הדאיה אלקאר": חלק הדקדוּק יוֹצא לאוֹר ע"פ " 1987a.

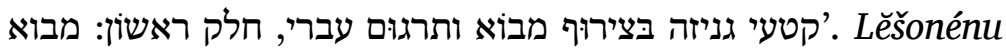
50: 214-31.

"מכתצר הדאיה אלקאר": חלק הדקדוּק יוֹצא לאוֹר ע"פ ' 1987b.

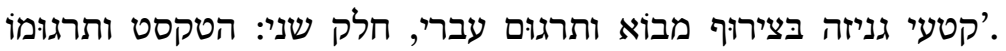
Lěšonénu 51: 3-41.

. 1994. The Study of the Art of Correct Reading as Reflected in the Medieval Treatise Hidāyat Al-Qāri. Jerusalem: Academy of the Hebrew Language (in Hebrew).

- 2018. The Masoretic Accentuation of the Hebrew Bible According to the Medieval Treatise Horayat Haqore. Jerusalem: Bialik Institute (in Hebrew).

Fārābī, 'Abū al-Nașr al-. 1960. شرح الفار ابى لكتاب ارسطوطاليس فى العبارة. Edited by Wilheim Kutch and Stanley B. Marrow. Beirut: Catholic Press.

Feldman, Louis H. 1992. 'Some Observations on Rabbinic Reaction to Roman Rule in Third Century Palestine'. Hebrew Union College Annual 63: 39-81.

Freimark, Peter. 1967. 'Das Vorwort als literarische Form in der arabischen Literatur'. Ph.D. Thesis, Münster: University of Münster.

Gallego, María Ángeles. 2003. 'Orígenes y Evolución del Lenguaje Según el Gramático y Exegeta Caraíta Abū l-Farağ Hārūn Ibn al-Farağ'. Sefarad 63: 43-67.

Gil, Moshe. 1996. 'The Jewish Community'. In The History of Jerusalem: The Early Muslim Period (638-1099), edited by 
Joshua Prawer and Haggai Ben-Shammai, 163-200. Jerusalem-New York: Yad Izhak Ben-Zvi and New York University Press.

Goldstein, Miriam. 2014. 'Arabic Book Culture in the Work of a Jerusalem Karaite: Abū 1-Faraj Hārūn and His Glossary of Difficult Biblical Words'. Zeitschrift der Deutschen Morgenländischen Gesellschaft 164: 345-73.

Hadassi, Judah ben Elijah ha-Abel. 1836. ספר אשכול הכופר. Eupatoria: Mordechai Tirisken.

Harviainen, Tapani. 1996. 'The Cairo Genizot and Other Sources of the Firkovich Collection in St. Petersburg'. In Proceedings of the Twelfth International Congress of the International Organization for Masoretic Studies, edited by E. John Revell, 25-36. Atlanta, GA: Scholars Press.

Hayman, A. Peter. 2004. Sefer Yeșira: Edition, Translation and Text-Critical Commentary. Tübingen: Mohr Siebeck.

Jastrow, Marcus. 1903. Dictionary of the Targumim, the Talmud Babli and Yerushalmi, and the Midrashic Literature. London: Luzac.

Khan, Geoffrey. 1990. 'The Opinions of al-Qirqisānī concerning the Text of the Bible and Parallel Muslim Attitudes towards the Text of the Qur'ān'. Jewish Quarterly Review 81: 59-73.

_. 1992. 'The Medieval Karaite Transcriptions of Hebrew in Arabic Script'. Israel Oriental Studies 12: 157-76. . 1993. 'On the Question of Script in Medieval Karaite Manuscripts: New Evidence from the Genizah'. Bulletin of the John Rylands University Library of Manchester 75: 13341. 
1997. 'Abū Al-Faraj Hārūn and the Early Karaite Grammatical Tradition'. Journal of Jewish Studies 48: 314-34. . 2000a. Early Karaite Grammatical Texts. Masoretic Studies

9. Atlanta: Society of Biblical Literature.

. 2000b. The Early Karaite Tradition of Hebrew Grammatical Thought: Including a Critical Edition, Translation and Analysis of the Diqduq of 'Abū Ya'qūb Yūsuf Ibn Nūḥ on the Hagiographa. Studies in Semitic Languages and Linguistics 32. Leiden: Brill.

- 2001. 'Biblical Exegesis and Grammatical Theory in the Karaite Tradition'. In Exegesis and Grammar in Medieval Karaite Texts, edited by Geoffrey Khan, 127-49. Journal of Semitic Studies Supplement 13. Oxford: Oxford University Press.

—_ 2007. 'The Contextual Status of Words in the Early Karaite Tradition of Hebrew Grammar'. In Sha'arei Lashon. Studies in Hebrew, Aramaic, and Jewish Languages Presented to Moshe Bar-Asher, edited by Aharon Maman, Steven E. Fassberg, and Yohanan Breuer, *117-*131. Jerusalem: Bialik Institute.

—_ 2013a. 'Morphology in the Medieval Karaite Grammatical Tradition'. In Encyclopedia of Hebrew Language and Linguistics, edited by Geoffrey Khan, Shmuel Bolozky, Steven E. Fassberg, Gary A. Rendsburg, Aaron D. Rubin, Ora R. Schwartzwald, and Tamar Zewi, 2:707-12. LeidenBoston: Brill.

. 2013b. 'Root: Medieval Karaite Notions'. In Encyclopedia of Hebrew Language and Linguistics, edited by Geoffrey Khan, 
Shmuel Bolozky, Steven E. Fassberg, Gary A. Rendsburg, Aaron D. Rubin, Ora R. Schwartzwald, and Tamar Zewi, 3:420-24. Leiden-Boston: Brill.

Khan, Geoffrey, María Ángeles Gallego, and Judith OlszowySchlanger. 2003. The Karaite Tradition of Hebrew Grammatical Thought in Its Classical Form: A Critical Edition and English Translation of Al-Kitāb Al-Kāfi fi Al-Lugia Al'Ibrāniyya by 'Abū al-Faraj Hārūn Ibn al-Faraj. Studies in Semitic Languages and Linguistics 37. Leiden: Brill.

Kretzmann, Norman. 1974. 'Aristotle on Spoken Sound Significant by Convention'. In Ancient Logic and Its Modern Interpretations, edited by John Corcoran, 3-21. Boston: Reidel.

Levin, Aryeh. 1997. 'The Theory of al-Taqdìr and its Terminology'. Jerusalem Studies in Arabic and Islam 21: 142-66.

Levy, Kurt. 1936. Zur Masoretischen Grammatik. Bonner Orientalistische Studien 15. Stuttgart: Kohlhammer.

Lipschütz, Lazar. 1965. Kitāb al-Khilaf: Mishael Ben Uzziel's Treatise on the Differences between Ben Asher and Ben Naphtali. Publications of the Hebrew University Bible Project 2. Jerusalem: Magnes Press.

Loucel, Henri. 1963. 'L'origine du Langage d'après les Grammairiens Arabes II'. Arabica 10: 253-81.

Makkī ibn 'Abī Ṭālib al-Qaysī. 1996. الرعاية لتجويد القراءة وتحقيق لفظ التلاوة. Edited by Aḥmad Ḥasan Farḥāt. Amman: Dār 'Ammār.

Morag, Shelomo. 1960. 'שבע כפולות בגדכפר״ת'. In טור־סיניי'

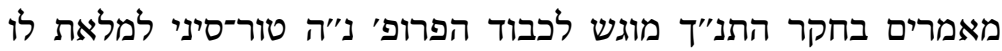


שבעים שנה, edited by Menahem Haran and Ben-Tsiyon Lurya, 207-43. Jerusalem: Kiryath Sepher.

Nelson, Kristina. 2001. The Art of Reciting the Qur'an. American University in Cairo Press.

Peters, Johannes, R. T. M. 1976. God's Created Speech: A Study in the Speculative Theology of the Mu'tazilî Qâdî l-Quḍ̂t Abû lHasan 'Abd al-Jabbâr bn Aḥmad al-Hamadânî. Leiden: Brill. Pines, Shlomo. 1969. The Guide of the Perplexed: Moses Maimonides. Second American Edition. The University of Chicago Press.

Polliack, Meira. 1997. The Karaite Tradition of Arabic Bible Translation: A Linguistic and Exegetical Study of Karaite Translations of the Pentateuch from the Tenth and Eleventh Centries C.E. Études sur le Judaïsme Médiéval 17. Leiden: Brill.

Posegay, Nicholas. 2020 (to appear). 'Connecting the Dots: The Shared Phonological Tradition in Syriac, Arabic, and Hebrew Vocalisation'. In Studies in Semitic Vocalization and Reading Traditions, edited by Geoffrey Khan and Aaron Hornkohl. Cambridge Semitic Languages and Cultures. Cambridge: University of Cambridge \& Open Book Publishers.

Saenz-Badillos, Angel. 2004. 'The Origin of the Language and Linguistic Pluralism according to Medieval Jewish Exegetes'. In Verbum et Calamus; Semitic and Related Studies in Honour of the Sixtieth Birthday of Professor Tapani Harviainen, edited by Hannu Juusola, Juha Laulainen, and Heikki Palva, 293-303. Helsinki: Finnish Oriental Society. 
Sklare, David. 2017. 'Mu'tazili Trends in Jewish Theology'. İslâmî İlimler Dergisi 12: 145-78.

Stroumsa, Sarah. 2007. 'A Literary Genre as an Historical Document: On Saadia's Introductions to his Bible Commentaries'. In "A Word Fitly Spoken:" Studies in Qur'an and Bible Exegesis Presented to Haggai Ben-Shammai, edited by Meir M. Bar-Asher, Simon Hopkins, Sarah Stroumsa, and Bruno Chiesa, 193-204. Jerusalem: Ben-Zvi Institute and Hebrew University.

Vajda, Georges. 1974. 'La Parole Créée de Dieu d-après le Théologien Karaïte Yūsuf al-Bașîr'. Studia Islamica 39: 5976.

Vidro, Nadia. 2011. Verbal Morphology in the Karaite Treatise on Hebrew Grammar: Kitāb al-'Uqūd fi Taṣārif al-Lugia al-Tbrāniyya. Études sur le Judaïsme Médiéval 51. Leiden: Brill.

- 2013a. A Medieval Karaite Pedagogical Grammar of Hebrew: A Critical Edition and English Translation of Kitāb al-'Uqūd fi Tasāāif al-Lugia al-'Tbrāniyya. Études sur le Judaïsme Médiéval 62. Leiden: Brill.

—_. 2013b. 'Mnemonics'. In Encyclopedia of Hebrew Language and Linguistics, edited by Geoffrey Khan, Shmuel Bolozky, Steven E. Fassberg, Gary A. Rendsburg, Aaron D. Rubin, Ora R. Schwartzwald, and Tamar Zewi, 2:650-53. LeidenBoston: Brill.

Weiss, Bernard G. 1974. 'Medieval Muslim Discussions of the Origin of Language'. Zeitschrift der Deutschen Morgenländischen Gesellschaft 124: 33-41. 
Wolfson, Harry. 1979. Repercussions of the Kalam in Jewish Philosophy. Cambridge, MA: Harvard University Press. Zimmermann, Fritz W. 1982. Al-Farabi's Commentary and Short Treatise on Aristotle's De Interpretatione. Classical and Medieval Logic Texts 3. London: Oxford University Press. Zislin, Meir N. 1990. Me'or 'Ayin. Moscow: Nauka.

Zwiep, Irene E. 1997. Mother of Reason and Revelation: A Short History of Medieval Jewish Linguistic Thought. Amsterdam Studies in Jewish Thought 5. Amsterdam: J.C. Gieben. 


\section{INDEXES}

\section{GENERAL INDEX}

(Numbers refer to pages)

'Abd al-Jabbār al-Hamadhānī:

260, 261, 265, 266, 267

'Abū al-Bakr al-Bāqillānī: 285

'Abū al-Faraj Furqān ibn 'Asad

(Yeshu'a ben Yehuda): 256, 261

'Abū al-Faraj Hārūn: 1, 2, 3, 5, $6,7,10,11,15,16,254$, $255,256,257,259,260$, $261,262,264,265,266$, 267, 268, 269, 271, 273, 274, 275, 276, 278, 279, $280,281,282,283,284$, 285, 289, 290, 292, 293, 294, 302, 310

'Abū al-Hasan Dā'ūd ibn 'Imrān ibn Levi: 256 'Abū al-Ḥusayn al-Bașrī: 261 'Abū 'Alī ibn Khallād: 260

'Abū al-Ṭayyib Samuel ibn

Manșūr: 256

'Abū Hāshim al-Jubbā'ī: 260, 261

'Abū 'Isḥāq al-'Asfarā'īnī: 285 accusative: 293 'ahl al-lugha: 259, 272, 283

'alāma: 289

al-Dānī, 'Abū 'Amr 'Uthmān

ibn Sa'īd: 4, 266, 305

al-Durr al-Nathir w-al-'Adhb al-

Namir: 266

al-Fārābī: 260

'Alfāz al-Sa ba allatī li-l-Torah:

7

al-Kitāb al-Käfi fi al-Lugha al-'Tbrāniyya: 5, 6, 10, 11, 254, 256, 259, 260, 268, $269,273,274,278,280$, 281, 282, 289, 293, 294, 295, 296, 300

al-Kitāb al-Muhtawĩ: 265

al-Kitāb al-Mushtamil 'alā al-'Ușūl wa-l-Fușūl fĩ al-Lugha al-Tbrāniyya: 6, 269, 279 al-Mālaqī' 'Abd al-Wāhìid ibn Muhammad ibn 'Abī alSaddād: 266, 304 anagrammatical: 279 Arabic linguistic thought: 3 Aristotle: 260, 261, 284, 310, 313

Babylonian pronunciation tradition: 271 
Bahshamiyya: 260

Bașra: 260

conjugation: $4,19,20,21,22$, $278,281,282,287,289$, 290, 292, 293, 294, 296

convention: 259, 260, 261, $262,265,266,272,277$, $283,284,285$

De Interpretatione: 260, 313

Diqduq: 256, 272, 278, 295, 300, 309

Diqduqe ha-Ṭe'amim: 258, 302 genitive: 258

Genizah: 1, 7, 10, 268, 309 ha-'Egron: 255

Hai Gaon: 280

Ḥayyūj, Yaḥyā ibn Dā’ūd: 270, 277

hireq: 18, 20, 22, 286, 290, 291, 293, 294, 295, 297

holem: 20, 22, 286, 290, 291, 292

hurūf al-lìn: 270, 276

Ibn Sīnā: 5

'ikhtișār: 282

imperative: 16, 275, 278, 279, 280, 281, 287, 288, 289, 290, 291, 292, 293, 294, 295, 296

infinitive: 17, 278, 281, 292, 293, 294, 295 jawhar: 279

Jerusalem: 1, 260, 261, 262, $263,305,306,307,308$, $310,311,312$

kalām: 5, 265

Karaites: 1, 10, 16, 256, 258, 260, 261, 262, 263, 264, $265,268,270,272,275$, 278, 279, 281, 287, 288, 290, 295, 296, 300, 308, 309, 310, 311, 313

khafd: 17, 285

Kitāb al-'Alhāān: 7, 256

Kitāb al-Hāwĩ: 280

Kitāb al-Hidāya fì 'Ilm Shurūt alMiqrā: 7

Kitāb al-Muhja: 7

Kitāb al-Musawwitāt: 5, 299, 301

Kitāb al-Shurūt: 6

Kitāb al-'Uqūd fi Tașārīf alLugha al-Tbrāniyya: 254, 265, 281, 290, 291, 292, 293, 294, 295, 296, 313

Kitāb Fasịh Lughat al'Tbrāniyyin: 280, 282 maf'ūl muṭlaq: 17, 293 mașādir musta'āra: 294 Me'or 'Ayin: 290, 296, 313 mnemonic: 289, 301 
morphology: 4, 5, 6, 275, 278, $279,281,286,287,288$, 289, 292

mubtadas: 292

muḍāf: 17, 275

Mu'tazila: 260

naṣb: 18, 285, 286, 287

paratext: 254, 255

patah: $13,18,20,21,22,286$, 290, 293, 294, 296, 303

philosophy: $2,4,5,6,260$

postface: 254,256

preface: 3, 254, 263

qat': 19, 275

qibbus: 16

Qur'ān: 3, 5, 264, 309

raf: 19, 285, 291, 292

resh: 22, 270, 273, 277, 293

revelationist: 262, 284, 285

ribāṭ: 289

root: $21,258,261,278,279$,

282

Saadya: 255, 280, 282, 284, 285

Seder ha-Simanim: 5, 255, 301

Sefer 'Eshkol ha-Kofer: 262

Sefer Yeșira: 271, 309

segol: 13, 19, 21, 286, 290,

293

șere: $18,21,22,286,289$, 290, 296
Sharh 'Alfā̄z allatĭ fïhā Șu'ūba fi al-Miqrā wa-Dhikr Ishtiqāqihā: 7

shewa: 4, 6, 14, 19, 267, 297, 298, 299, 300, 303, 304

shureq: 22, 286, 292 soft letters (hurūf al-lin): 16, 270, 276

speculative theology: 5 tafkhim: 280 Tafsìr 'Alfäz al-Miqrā: 7, 254 tajwid: 3, 4, 5, 266 taqdirr: 19, 274, 276, 282 tav: $13,22,273,277$ transposed infinitive: 18, 294 verbal noun: 258, 293 vernacular: 13 vocalization: $2,11,12,13,15$, 267, 291, 299

Yeshu'a ben Yehuda $\rightarrow$ 'Abū al-Faraj Furqān ibn 'Asad Yūsuf ibn Ibrāhīm ha-Kohen alBașir: 260, 261, 265, 312 Yūsuf ibn Nūḥ: 256, 257, 272, 278, 295, 300, 309 


\section{MANUSCRIPTS}

(Numbers refer to pages)

Cambridge, University

Library

Mosseri I, 57.2: 10

Mosseri I, 71.1: 276

T-S D1.2: 268, 276

T-S NS 301.23: 8

T-S NS 301.84: 267

T-S NS 311.113: 7

Manchester, John Rylands

Library

JRL A 694: 1,7

New York, Jewish

Theological Seminary

JTS 8110, EMC 829, 832: 8

\section{Oxford, Bodleian Library}

Bod. Heb. d 33, fol. 16: 276

\section{St. Petersburg, National}

Library of Russia

II Firkovitch, Evr.-Arab. I 2347: 9

II Firkovitch, Evr.-Arab. I 2390: 8
II Firkovitch, Evr.-Arab. I 2477: 9

II Firkovitch, Evr.-Arab. I 2478: 9

II Firkovitch, Evr.-Arab. I 2480: 9

II Firkovitch, Evr.-Arab. I 2481: 9

II Firkovitch, Evr.-Arab. I 2505: 8

II Firkovitch, Evr.-Arab. I 2528: 9

II Firkovitch, Evr.-Arab. I 2542: 9

II Firkovitch, Evr.-Arab. I 2544: 9

II Firkovitch, Evr.-Arab. I 2551: 9

II Firkovitch, Evr.-Arab. I 2557: 9

II Firkovitch, Evr.-Arab. I 2772: 9

II Firkovitch, Evr.-Arab. I 2794: 9

II Firkovitch, Evr.-Arab. I 2795: 9

II Firkovitch, Evr.-Arab. I 2813: 9

II Firkovitch, Evr.-Arab. I 2814: 9 
II Firkovitch, Evr.-Arab. I 2897: 9

II Firkovitch, Evr.-Arab. I 2928: 9

II Firkovitch, Evr.-Arab. I 2941: 9

II Firkovitch, Evr.-Arab. I 2945: 9

II Firkovitch, Evr.-Arab. I 2966: 9

II Firkovitch, Evr.-Arab. I 3384: 10

II Firkovitch, Evr.-Arab. I 3944: 10

II Firkovitch, Evr.-Arab. I 4477: 8

II Firkovitch, Evr.-Arab. I 4601: 269

II Firkovitch, Evr.-Arab. II 297: 10

II Firkovitch, Evr.-Arab. II 307: 8

II Firkovitch, Evr.-Arab. II 323: 10

II Firkovitch, Evr.-Arab. II 325: 10

II Firkovitch, Evr.-Arab. II 326: 10

II Firkovitch, Evr.-Arab. II 418: 8
II Firkovitch, Evr.-Arab. II 420: 10

II Firkovitch, Evr.-Arab. II 488: 10

II Firkovitch, Evr.-Arab. II 604: 8

BibliCAl VERSES IN

HIDĀYAT AL-QĀRI'

(LONG VERSION)

(Numbers refer to

paragraphs)

\section{Genesis}

Gen. 1.1: II.L.0.5.

Gen. 1.3: II.L.2.2.1.

Gen. 1.22: II.L.1.13.

Gen. 1.24: II.L.1.11.3.

Gen. 2.5: II.L.2.12.1.4.

Gen. 2.12: II.L.2.13.3.

Gen. 2.16: II.L.2.2.2.

Gen. 4.4: II.L.1.13.

Gen. 4.9: II.L.1.13.

Gen. 7.23: II.L.1.13.

Gen. 9.1: II.L.2.12.1.1.

Gen. 10.4: II.L.1.12.2.

Gen. 12.3: II.L.3.2.7.

Gen. 14.2: II.L.1.10.

Gen. 18.1: II.L.2.12.8.1.

Gen. 18.5: II.L.1.6. 
Gen. 18.17: II.L.1.7.11.

Gen. 18.21: II.L.1.7.3.

Gen. 19.20: II.L.1.5.7.

Gen. 20.5: II.L.2.12.6.

Gen. 20.13: II.L.1.4.4.

Gen. 23.10: II.L.2.12.1.4.

Gen. 24.21: II.L.1.9.7.

Gen. 24.32: II.L.1.9.7.

Gen. 25.34: II.L.1.13.

Gen. 26.11: II.L.2.12.3.2.

Gen. 27.19: II.L.3.2.7.

Gen. 27.24: II.L.1.4.8.

Gen. 29.21: II.L.1.13.

Gen. 32.8: II.L.1.12.2.

Gen. 34.29: II.L.0.1.

Gen. 39.12: II.L.1.7.9.

Gen. 39.15: II.L.1.7.11.

Gen. 39.19: II.L.1.7.11.

Gen. 42.10: II.L.1.8.1.

Gen. 43.26: II.L.1.3.2.

Gen. 45.12: II.L.2.13.1.

Gen. 46.3: II.L.1.11.2.

Gen. 46.26: II.L.0.1.; II.L.0.1.

Gen. 46.27: II.L.0.1.; II.L.0.1.

Gen. 49.6: II.L.1.6.

Gen. 49.11: II.L.1.4.7.

Gen. 49.13: II.L.1.5.12.

Gen. 49.26: II.L.3.2.7.

\section{Exodus}

Exod. 4.19: II.L.2.13.1.
Exod. 5.1: II.L.1.12.2.

Exod. 6.27: II.L.2.12.8.2.;

II.L.2.13.1.

Exod. 8.20: II.L.1.10.

Exod. 14.4: II.L.1.7.10.

Exod. 14.30: II.L.1.7.2.

Exod. 15.1: II.L.1.7.2.

Exod. 15.4: II.L.3.2.1.

Exod. 15.16: II.L.1.7.2.

Exod. 17.6: II.L.1.5.2.

Exod. 22.4: II.L.1.10.

Exod. 23.31: II.L.1.11.6.

Exod. 28.8: II.L.2.12.1.3.

Exod. 28.43: II.L.2.12.5.

Exod. 32.1: II.L.1.12.2.

Exod. 32.11: II.L.3.2.3.

Exod. 32.20: II.L.1.13.

\section{Leviticus}

Lev. 4.23: II.L.2.16.

Lev. 5.5: II.L.1.5.12.

Lev. 6.13: II.L.1.7.6.

Lev. 11.15: II.L.1.10.

Lev. 14.11: II.L.1.4.2.;

II.L.1.4.2.

Lev. 15.25: II.L.3.2.4.

Lev. 19.5: II.L.1.9.7.

Lev. 19.6: II.L.2.12.2.2.

Lev. 20.2: II.L.1.9.7.

Lev. 21.13: II.L.1.7.9.

Lev. 22.13: II.L.0.1. 
Lev. 23.17: II.L.1.3.2.

Lev. 24.20: II.L.2.17.

Lev. 26.34: II.L.0.3

Lev. 26.43: II.L.1.13.

\section{Numbers}

Num. 5.19: II.L.2.13.1.

Num. 9.10: II.L.1.6.

Num. 10.35: II.L.1.11.2.

Num. 10.36: II.L.1.11.2.

Num. 11.11: II.L.3.2.3.

Num. 11.15: II.L.2.12.1.1.

Num. 14.12: II.L.1.7.8.

Num. 14.19: II.L.1.11.2.

Num. 16.24: II.L.2.8.1.

Num. 17.10: II.L.2.8.1.

Num. 17.23: II.L.1.4.10.

Num. 21.1: II.L.2.12.14.

Num. 24.3: II.L.1.4.7.; II.L.1.5.21.; II.L.1.11.3.

Num. 24.5: II.L.2.16.

Num. 25.7: II.L.2.16.

Num. 26.35: II.L.1.6.

\section{Deuteronomy}

Deut. 3.27: II.L.1.13.

Deut. 4.7: II.L.1.7.8.

Deut. 4.36: II.L.1.3.4.

Deut. 9.14: II.L.2.7.3.

Deut. 13.6: II.L.1.10.

Deut. 13.11: II.L.1.6.
Deut. 28.49: II.L.1.13.

Deut. 28.61: II.L.2.12.7.

Deut. 31.24: II.L.2.12.5.

Deut. 31.28: II.L.1.7.4.

\section{Joshua}

Josh. 1.5: II.L.1.4.10.

Josh. 1.8: II.L.1.7.4.

Josh. 2.18: II.L.1.7.4.

Josh. 4.22: II.L.2.12.2.2.

Josh. 5.1: II.L.1.7.4.

Josh. 6.2: II.L.1.7.4.

Josh. 6.9: II.L.2.12.8.1.

Josh. 6.17: II.L.1.7.6.

Josh. 7.7: II.L.1.3.4.

Josh. 7.9: II.L.1.7.4.

Josh. 8.14: II.L.2.12.4.2.

Josh. 8.28: II.L.1.9.2.

Josh. 10.4: II.L.2.12.6.

Josh. 10.6: II.L.1.13.

Josh. 10.38: II.L.1.11.2.

Josh. 13.3: II.L.1.9.7.

Josh. 15.4: II.L.1.11.2.

Josh. 15.6: II.L.2.12.1.4.

Josh. 15.18: II.L.1.7.9.

Josh. 18.27: II.L.1.9.7.

Josh. 19.35: II.L.2.12.1.4.

Josh. 19.38: II.L.2.12.7.

Josh. 24.15: II.L.2.12.1.4. 


\section{Judges}

Jud. 1.27: II.L.2.12.1.1.

Jud. 3.25: II.L.1.12.2.

Jud. 5.12: II.L.0.1.;

II.L.2.12.8.2.

Jud. 5.16: II.L.2.14.

Jud. 5.23: II.L.1.12.2.

Jud. 5.28: II.L.3.2.1.

Jud. 7.19: II.L.1.12.3.

Jud. 7.25: II.L.1.10.;

II.L.2.12.3.1.

Jud. 11.35: II.L.1.7.11.

Jud. 14.17: II.L.1.13.

Jud. 15.5: II.L.1.10.

Jud. 15.10: II.L.3.2.3.

\section{Samuel}

1 Sam. 1.6: II.L.1.9.6.

1 Sam. 7.8: II.L.2.12.12.

1 Sam. 8.7: II.L.2.12.12.

1 Sam. 14.4: II.L.2.16.;

II.L.3.2.4.

1 Sam. 17.5: II.L.1.5.19.

1 Sam. 17.15: II.L.1.9.7.

1 Sam. 17.47: II.L.1.11.5.

1 Sam. 18.11: II.L.1.4.9.

1 Sam. 18.30: II.L.1.7.8.

1 Sam. 20.4: II.L.1.7.4.; II.L.3.2.2.

1 Sam. 24.19: II.L.2.16.

1 Sam. 26.23: II.L.1.4.8.
1 Sam. 28.7: II.L.1.7.5.

1 Sam. 28.9: II.L.3.2.3.

1 Sam. 28.15: II.L.3.2.3.

\section{Samuel}

2 Sam. 3.33: II.L.2.12.12.

2 Sam. 7.13: II.L.1.7.5.

2 Sam. 7.29: II.L.3.2.7.

2 Sam. 10.16: II.L.1.4.4.

2 Sam. 12.28: II.L.2.12.6.

2 Sam. 14.31: II.L.3.2.3.

2 Sam. 19.28: II.L.1.5.11.

2 Sam. 19.44: II.L.1.13.

2 Sam. 22.12: II.L.1.5.20.

2 Sam. 24.2: II.L.1.12.2.

\section{Kings}

1 Kings 1.40: II.L.2.12.12.

1 Kings 3.23: II.L.1.7.4.

1 Kings 4.12: II.L.2.12.9.

1 Kings 6.9: II.L.1.13.

1 Kings 9.15: II.L.2.12.1.1.

1 Kings 10.2: II.L.1.11.2.

1 Kings 15.29: II.L.1.7.11.

1 Kings 17.2: II.L.1.6.

\section{Kings}

2 Kings 3.20: II.L.1.5.11.

2 Kings 4.13: II.L.3.2.2.

2 Kings 4.40: II.L.1.5.11.

2 Kings 5.11: II.L.1.12.2. 
2 Kings 5.26: II.L.3.2.1.

2 Kings 6.32: II.L.1.9.6.

2 Kings 20.17: II.L.1.11.2.

2 Kings 25.10: II.L.1.5.15.

\section{Isaiah}

Isa. 10.9: II.L.1.7.9.

Isa. 10.25: II.L.1.5.7.

Isa. 10.28: II.L.1.5.12.

Isa. 14.23: II.L.1.5.7.

Isa. 22.7: II.L.1.5.21.

Isa. 22.19: II.L.1.5.10.

Isa. 24.19: II.L.1.12.2.

Isa. 27.2: II.L.2.12.2.2.

Isa. 29.9: II.L.1.5.6.

Isa. 34.11: II.L.1.7.7.

Isa. 40.12: II.L.3.2.6.

Isa. 40.20: II.L.2.13.1.

Isa. 41.25: II.L.1.13.

Isa. 42.8: II.L.2.12.6.

Isa. 42.17: II.L.1.5.3.

Isa. 43.2: II.L.1.11.4.

Isa. 43.7: II.L.3.2.6.

Isa. 44.14: II.L.1.5.22.

Isa. 47.5: II.L.1.12.2.

Isa. 47.12: II.L.1.7.8.

Isa. 54.12: II.L.1.7.2.

Isa. 57.18: II.L.2.12.3.1.

Isa. 59.10: II.L.1.5.3.

Isa. 59.21: II.L.1.7.10.

Isa. 60.1: II.L.1.1.5.
Isa. 60.17: II.L.1.9.2.

Isa. 61.10: II.L.1.13.

Isa. 65.8: II.L.3.1.

\section{Jeremiah}

Jer. 3.20: II.L.1.5.13.

Jer. 4.1: II.L.1.12.2.

Jer. 4.31: II.L.2.12.1.3.

Jer. 8.15: II.L.2.7.2.

Jer. 11.10: II.L.0.1.

Jer. 11.15: II.L.3.2.2.

Jer. 13.17: II.L.1.5.6.

Jer. 15.18: II.L.3.2.3.

Jer. 20.9: II.L.1.7.2.

Jer. 22.23: II.L.2.12.14.

Jer. 23.16: II.L.1.3.4.

Jer. 38.9: II.L.2.11.2.

Jer. 40.16: II.L.1.5.1.

Jer. 44.28: II.L.2.12.8.1.

Jer. 46.8: II.L.1.13.

Jer. 46.15: II.L.1.5.17.

Jer. 51.16: II.L.1.13.

Jer. 51.58: II.L.1.12.3.

Jer. 52.15: II.L.1.5.1.

\section{Ezekiel}

Ezek. 5.15: II.L.1.3.3.

Ezek. 16.4: II.L.2.10.2.;

II.L.2.12.14.

Ezek. 16.47: II.L.1.11.1. 
Ezek. 17.9: II.L.1.5.15.; II.L.1.9.7.

Ezek. 20.44: II.L.1.11.1.

Ezek. 22.5: II.L.2.12.3.1.

Ezek. 23.40: II.L.2.10.4.; II.L.2.12.14.

Ezek. 32.20: II.L.2.12.6; II.L.2.12.9.

Ezek. 35.15: II.L.2.12.3.2.

Ezek. 40.10: II.L.1.9.2.

Ezek. 40.34: II.L.1.4.3.

Ezek. 45.9: II.L.2.12.3.1.

Ezek. 46.14: II.L.1.12.2.

\section{Hosea}

Hos. 5.15: II.L.2.13.2.

\section{Amos}

Amos 6.3: II.L.2.13.1.

\section{Obadiah}

Obd. 1.20: II.L.1.9.7.

\section{Zephaniah}

Zeph. 2.14: II.L.1.12.3.

Zeph. 3.8: II.L.0.1.; II.L.1.1.5.

\section{Zechariah}

Zech. 11.17: II.L.1.13.

Zech. 13.9: II.L.1.9.7.

\section{Malachi}

Mal. 2.13: II.L.2.12.5.

\section{Psalms}

Psa. 2.9: II.L.1.12.2.

Psa. 3.3: II.L.1.11.2.

Psa. 8.7: II.L.1.5.21.

Psa. 17.12: II.L.1.9.7.

Psa. 18.11: II.L.1.13.

Psa. 22.3: II.L.2.6.

Psa. 22.15: II.L.3.2.6.

Psa. 25.20: II.L.2.12.9.

Psa. 27.1: II.L.0.1.

Psa. 28.7: II.L.1.11.5.

Psa. 42.10: II.L.3.2.3.

Psa. 43.2: II.L.3.2.3.

Psa. 45.12: II.L.1.13.

Psa. 47.5: II.L.3.2.5.

Psa. 49.6: II.L.3.2.3.

Psa. 50.20: II.L.2.16.

Psa. 59.12: II.L.1.11.6.

Psa. 60.2: II.L.3.2.5.

Psa. 66.6: II.L.2.12.2.2.

Psa. 66.17: II.L.1.7.7.

Psa. 68.31: II.L.1.4.4.

Psa. 68.35: II.L.1.11.1.

Psa. 72.6: II.L.1.9.7.

Psa. 73.9: II.L.1.5.21.

Psa. 74.6: II.L.1.4.9.

Psa. 82.5: II.L.1.12.2.

Psa. 88.11: II.L.1.7.5. 
Psa. 89.18: II.L.1.11.6.

Psa. 89.53: II.L.2.12.1.4.

Psa. 92.4: II.L.1.11.4.

Psa. 92.7: II.L.1.10.

Psa. 92.15: II.L.1.12.2.

Psa. 94.17: II.L.1.12.2.;

II.L.2.6.

Psa. 98.8: II.L.2.12.1.6.

Psa. 100.4: II.L.1.7.7.

Psa. 103.3: II.L.1.11.3.

Psa. 103.5: II.L.1.11.3.

Psa. 103.20: II.L.3.2.7.

Psa. 107.3: II.L.1.13.

Psa. 113.5: II.L.1.11.3.

Psa. 114.8: II.L.1.11.3.

Psa. 123.1: II.L.1.11.3.

Psa. 132.1: II.L.2.12.3.1.

Psa. 141.8: II.L.1.13.

\section{Proverbs}

Prov. 1.17: II.L.2.5.

Prov. 1.28: II.L.2.13.2.;

$$
\text { II.L.2.13.2. }
$$

Prov. 3.4: II.L.2.12.1.4.

Prov. 4.16: II.L.2.12.3.3.

Prov. 6.16: II.L.3.2.4.

Prov. 8.17: II.L.2.13.2.

Prov. 14.28: II.L.2.12.3.1.

Prov. 16.30: II.L.1.5.5.

Prov. 17.3: II.L.1.9.7.

Prov. 17.16: II.L.3.2.3.
Prov. 19.7: II.L.3.2.6.

Prov. 20.17: II.L.1.10.

Prov. 21.1: II.L.3.2.4.

Prov. 25.3: II.L.2.12.8.1.

Prov. 28.3: II.L.1.5.17.

Prov. 31.2: II.L.1.7.4.

Prov. 31.3: II.L.1.5.14.

\section{Job}

Job 1.1: II.L.2.12.8.1.

Job 3.21: II.L.2.13.1.

Job 7.11: II.L.1.12.2.

Job 10.22: II.L.1.11.2.

Job 16.4: II.L.1.11.4.

Job 16.5: II.L.1.11.4.

Job 16.12: II.L.1.12.3.

Job 17.1: II.L.1.12.2.

Job 18.16: II.L.1.12.2.

Job 19.3: II.L.1.3.4.

Job 26.11: II.L.1.5.17.

Job 28.1: II.L.1.12.2.

Job 31.35: II.L.3.2.4.

Job 36.30: II.L.2.16.

Job 37.18: II.L.1.4.8;

II.L.1.9.7.

Job 40.26: II.L.1.4.8.

Job 41.26: II.L.1.5.8.

\section{Song of Songs}

Cant. 1.11: II.L.1.9.2.

Cant. 5.2: II.L.1.9.5. 
Cant. 7.3: II.L.1.5.3.

Dan. 12.13: II.L.1.5.14.

Cant. 7.10: II.L.2.12.1.3.

Cant. 8.14: II.L.2.13.3.

\section{Ezra}

Ruth

Ezra 1.1: II.L.0.3

Ezra 3.7: II.L.2.12.8.1.

Ruth 2.6: II.L.0.1.

Ezra 4.23: II.L.1.7.9.

Ezra 8.18: II.L.1.3.2.

\section{Lamentations}

Lam. 1.4: II.L.1.9.7.

1 Chronicles

Lam. 3.23: II.L.2.17.

1 Chron. 1.6: II.L.1.5.4.

1 Chron. 1.7: II.L.1.5.4.

\section{Ecclesiastes}

1 Chron. 6.6: II.L.1.7.8.

Ecc. 11.9: II.L.1.4.2.

\section{Esther}

Esther 2.1: II.L.1.12.2.

Esther 5.2: II.L.1.7.11.

Esther 9.3: II.L.2.10.3.

\section{Daniel}

Dan. 3.2: II.L.1.7.2.

Dan. 3.5: II.L.1.5.9.; II.L.1.7.2.

Dan. 3.13: II.L.1.4.10.

Dan. 4.27: II.L.2.12.6.

1 Chron. 6.14: II.L.1.7.8.

1 Chron. 6.29: II.L.1.3.4.

1 Chron. 8.12: II.L.2.16.

1 Chron. 12.23: II.L.2.12.8.1.

1 Chron. 12.41: II.L.1.4.9.

1 Chron. 17.11: II.L.1.12.2.

1 Chron. 19.16: II.L.1.4.4.

1 Chron. 28.11: II.L.1.9.2.

1 Chron. 28.18: II.L.1.12.2.

\section{Chronicles}

2 Chron. 1.12: II.L.1.5.14.

Dan. 6.23: II.L.2.12.8.1.; II.L.2.13.3.; II.L.2.13.3.

Dan. 7.6: II.L.1.7.6.

Dan. 9.19: II.L.1.11.2.; II.L.1.11.2.

Dan. 10.14: II.L.1.5.5. 
BIbLICAL VERSES IN

HIDĀYAT AL-QĀRI'

(SHORT VERSION)

(Numbers refer to

paragraphs)

\section{Genesis}

Gen. 9.1: II.S.6.1.1.

Gen. 18.1: II.S.6.9.

Gen. 18.5: II.S.2.1.

Gen. 18.17: II.S.2.12.

Gen. 18.21: II.S.2.4.

Gen. 34.29: II.S.0.3

Gen. 39.12: II.S.2.10.

Gen. 39.15: II.S.2.12.

Gen. 39.19: II.S.2.12.

Gen. 43.26: II.S.1.2.

Gen. 45.12: II.S.5.4.

Gen. 49.6: II.S.2.1.

\section{Exodus}

Exod. 4.19: II.S.5.4.

Exod. 6.27: II.S.5.4.

Exod. 14.4: II.S.2.11.

Exod. 14.30: II.S.2.3.

Exod. 15.1: II.S.2.3.

Exod. 15.16: II.S.2.3.

Exod. 15.21: II.S.2.3.

Exod. 28.8: II.S.6.1.3.

Exod. 28.43: II.S.6.5.
Exod. 29.34: II.S.6.1.1.

\section{Leviticus}

Lev. 5.12: II.S.7.3.

Lev. 6.13: II.S.2.7.

Lev. 7.35: II.S.6.2.1.

Lev. 19.6: II.S.6.2.2.

Lev. 21.13: II.S.2.10.

Lev. 23.17: II.S.1.2.

\section{Numbers}

Num. 5.19: II.S.5.4.

Num. 5.22: II.S.5.4.

Num. 11.15: II.S.6.1.1.

Num. 11.29: II.S.5.4.

Num. 21.1: II.S.6.12.

Num. 22.2: II.S.2.13.

\section{Deuteronomy}

Deut. 4.7: II.S.2.9.

Deut. 31.24: II.S.6.5.

Deut. 31.28: II.S.2.5.

Joshua

Josh. 1.8: II.S.2.5.

Josh. 2.18: II.S.2.5.

Josh. 6.17: II.S.2.7.

Josh. 8.28: II.S.3.0.

Josh. 15.18: II.S.2.10.

Josh. 19.38: II.S.6.7. 


\section{Judges}

Jud. 4.9: II.S.6.2.1.

Jud. 5.16: II.S.7.8.

Jud. 7.25: II.S.6.3.1.

Jud. 9.13: II.S.5.4.

Jud. 11.35: II.S.2.12.

\section{Samuel}

1 Sam. 7.8: II.S.6.13.

1 Sam. 8.7: II.S.6.13.

1 Sam. 18.30: II.S.2.9.

1 Sam. 20.4: II.S.2.5.

1 Sam. 28.7: II.S.2.6.

\section{Samuel}

2 Sam. 7.13: II.S.2.6.

2 Sam. 12.28: II.S.6.6.1.

\section{Kings}

1 Kings 1.40: II.S.6.13.

1 Kings 3.23: II.S.2.5.

1 Kings 4.12: II.S.6.10.

1 Kings 15.29: II.S.2.12.

1 Kings 17.2: II.S.2.1.

\section{Kings}

2 Kings 7.8: II.S.5.4.

2 Kings 8.16: II.S.6.2.1.

\section{Isaiah}

Isa. 8.19: II.S.5.1.; II.S.5.4.

Isa. 10.9: II.S.2.10.

Isa. 27.2: II.S.6.2.2.

Isa. 34.11: II.S.2.8.

Isa. 47.12: II.S.2.9.

Isa. 59.21: II.S.2.11.

Isa. 60.1: II.S.0.3.

\section{Jeremiah}

Jer. 11.10: II.S.0.3.

Jer. 29.27: II.S.5.6.

Jer. 44.28: II.S.6.9.

\section{Ezekiel}

Ezek. 16.4: II.S.5.1.

Ezek. 16.11: II.S.6.1.6.

Ezek. 22.5: II.S.6.3.1.

Ezek. 32.20: II.S.6.6.1.

Ezek. 39.10: II.S.5.5. (2x)

Ezek. 45.9: II.S.6.3.1.

\section{Hosea}

Hos. 5.15: II.S.5.5.

Hos. 11.6: II.S.6.1.3.

\section{Zephaniah}

Zeph. 3.8: II.S.0.3 
Psalms

Psa. 27.1: II.S.0.3

Psa. 66.6: II.S.6.2.1.

Psa. 66.17: II.S.2.8.

Psa. 68.31: II.S.1.7.

Psa. 72.17: II.S.6.1.4.

Psa. 88.11: II.S.2.6.

Psa. 89.53: II.S.6.1.4.

Psa. 98.8: II.S.6.1.5.

Psa. 100.4: II.S.2.8.

Psa. 112.9: II.S.1.7.

Psa. 132.1: II.S.6.3.1.

Proverbs

Prov. 1.28: II.S.5.5.

Prov. 3.4: II.S.6.1.4.

Prov. 4.16: II.S.9.0.

Prov. 8.17: II.S.5.5.

Prov. 14.28: II.S.6.3.1.

Job

Job 20.18: II.S.1.7.

Job 29.22: II.S.9.0.

Job 33.21: II.S.1.2.

Esther

Esther 5.2: II.S.2.12.

Daniel

Dan. 1.4: II.S.5.5.
Dan. 2.13: II.S.2.7.

Dan. 3.28: II.S.6.1.5.

Dan. 7.6: II.S.2.7.

Dan. 12.12: II.S.5.4.

\section{Ezra}

Ezra 4.23: II.S.2.10.

Ezra 8.18: II.S.1.2.

\section{Chronicles}

1 Chron. 6.6: II.S.2.9.

1 Chron. 6.14: II.S.2.9.

1 Chron. 12.23: II.S.6.9.

1 Chron. 16.32: II.S.1.7.

1 Chron. 21.3: II.S.2.4.

1 Chron. 28.11: II.S.3.0. (2x)

2 Chronicles

2 Chron. 28.24: II.S.6.5.

TERMS AND WORDS IN

HIDĀYAT AL-QĀRI'

(LONG VERSION)

(Numbers refer to lines)

Nู: 742

ֵ: 741

ผุ: 742

ผ: $45,59,1177$

ผู: 767 
אהتخن: 203, 205, 295, 302, 789, $850,988,1134$

אוֹ: 451, 504, 510, 521, 529,

544

:אלאוֹיה 435, 437, 440, 445,

467, 471, 478, 480, 488,

491, 494

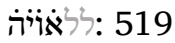

341

:אלאבתדא 146, 759, 1037

666, 1064

400

1036 :אלאבתדי

: 22, 35, 301, 526,

528 (2x), 566, 581, 608,

943, 1058, 1176

:> אהל> אללגה 1175

605, 779 :אלאואמר

431

421

:אוֹגָירָה 427

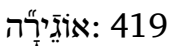

433

778 :ואוזאנהמא:

198

121

:21, 26, 34, 37, 57, 60,

74, 81, 85, 91, 94, 101, 112,

$125,172,179,182,949$,

1185, 1192, 1193

291 :ואלחאן
20

:אלף: 129, 139, 151, 152, 154,

154, 161, 162, 189, 320,

$344,511,979,987,1170$,

1226

7, 138, 141, 142, 164, 209, 224, 238, 241, 244,

244, 319, 342, 344, 77,5,

512, 514, 640, 699, 703,

854,860

356, 360, 367, 399

139

1031 :באלאלף 139

130

580

579 :אלאלפאט

:אמר: 16, 110, 131, 137, 167,

172

:אלאמר 396, 426, 429, 604, 604, 641, 750, 751, 767,

782, 788, 793, 795

: 168, 801

663 :אלאנחא

1171

:אסאס: 1149, 1150, 1151, 1152,

1152, 1153, 1154

: 306, 325, 572, 573, 693,

787

589, 592

753, 769

770 : ואסמא 753 


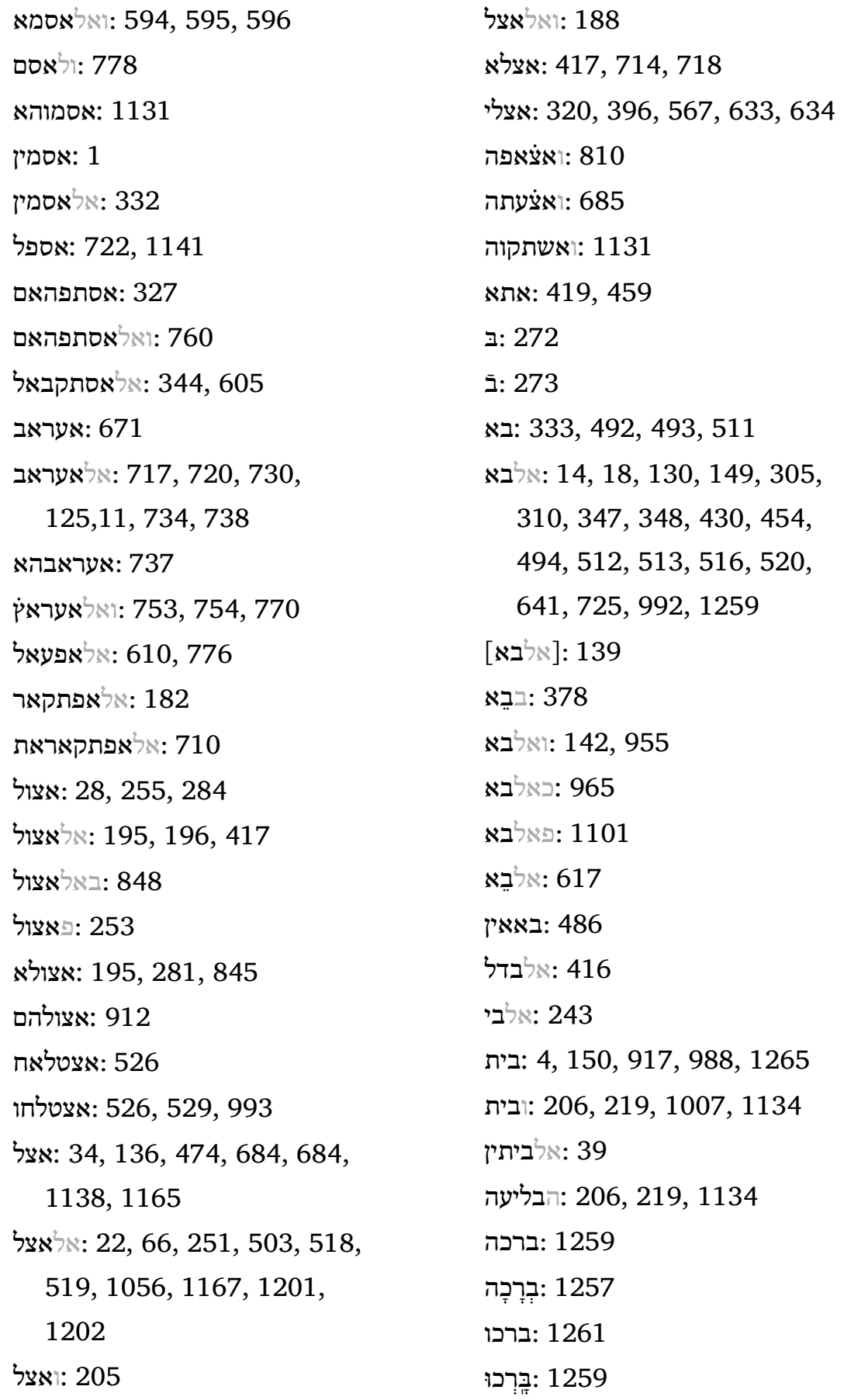


1267

1262

: 76, 125, 443, 534, 727, 739

(גזם 735

722, 743

:ואלגזם 734, 743, 744

799 :אלגזם

130, 642

: 134, 139, 252, 350,

618

352 :בגמאל

142 :ואלגמאל

1158 :ואלגמע

779, 790

1189 :געי

904, 1191

: 853, 855, 855, 859,

862, 863, 864, 870, 918,

920, 931, 932, 934, 939,

943, 945, 1186, 1187, 1199,

1199, 1200, 1202

937 :בגעיה

1190 :באלגעיה

944 :ללגעיה :

1200

דאל: 154, 155, 1103

: 131, 135, 151, 309,

354, 618, 643, 966, 990

[אלד]: 553

354
:ואלדאל : 261, 971

דגש: 208, 212, 213, 228, 232, 239, 483, 498, 537, 537, 928, 977, 981, 1214, 1220,

1233

: 208, 213, 215, 225, 232, 237, 240, 246, 261, 262, 263, 295, 452, 454, 534, 535, 559, 926, 982, 1089

:בדגש 241

:באלדגש 297

215, 294

537 :דגש כביר

535 :אלדגש אלכביר

502

דדחיק: 443, 444, 444, 520

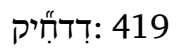

437 :דפסיק :41:

419

184, 631

: 10, 328, 356, 420, 465, 465, 607, 1226

: 11, 234, 326, 356, 466, 466, 591, 606, 619, 638, 639, 641, 642, 643, 697, 861, 862, 863, 865, 1110, 1110

:ואלהא 212, 216, 227, 402

223

: 881, 1049, 1112 
9 :אלהא

608 :אלהאאת

988

464

45, 61, 62, 65, 234, 278, 418, 426, 523, 607, 709, 709, 931, 932, 958, 1193,

1240

599

402

740 :ואו

475

112 :אלואצע:

685 :וואצעהא

749, 749, 749, 751

: 152, 200

: 152, 362, 563, 619, 645

354

1233

554 :ואלזאי

199 :ללזאי :

200

563 :אלזאי אלמכרוך : שי מכרוך

153

864, 884

723

724

1188 :חדפהא

608

:חית 184, 241, 881, 1039
:364, 620, 645, 866, 866, 1007

384, 1087

212

: 704, 1150, 1150

: 699, 702, 1134, 1151, 1153, 1154, 1158

1254

869 : [ב] חלם

870 :ואלחלם : ומים

1251

: 1151, 1152

205, 250

:250, 1139

: 130, 131, 131, 142, 145, 187, 190, 195, 197, 235, 237, 247, 255, 257, 264, 267, 271, 280, 293, 293, 77,5, 438, 477, 487, 521, 523, 523, 525, 544, 544, 545, 546, 560, 571, 700, 727, 788, 849, 850, 852, 873, 876, 893, 894, 902, 987, 988, 994, 1002, 1004, 1111, 1225, 1232 : 4, 123, 127, 136, 147, 156, 157, 163, 166, 167, 172, 178, 180, 188, 190, 202, 207, 224, 237, 246, 249, 277, 286, 286, 295, 313, 341, 342, 400, 531, 
532, 533, 536, 576, 614, 659, 668, 675, 676, 705, 728, 877, 887, 907, 908, 910, 931, 1175

290

565 :באלחרוף

: 186, 334, 846, 846

504

564, 675

: 190, 523, 525

: 173, 239, 547, 548

110 :חרופהא

719, 736

942 :אלחרכאת

32 :וחרכאת

696, 971, 1064

958 :אלחרכה

699 :בחרכה

699 :וחרכה :

963

1139, 1143

: 6, 99, 100, 129, 143, 143,

177, 177, 189, 191, 192,

195, 198, 337, 437, 445,

445, 462, 567, 605, 615,

627, 631, 633, 667, 669,

677, 712, 788, 812, 826,

850, 874, 888, 902, 948,

950, 951, 975, 977, 981,

987, 1006, 1010, 1013,
1045, 1070, 1086, 1239,

1242

: 4, 45, 128, 132, 146, 147, 148, 160, 161, 163, 166, 183, 184, 214, 215, 216, 218, 226, 232, 265, 269, 477, 479, 484, 512, 636, 671, 712, 714, 722, 723, 763, 800, 807, 809, 813, 827, 830, 831, 833, 856, 879, 925, 948, 954, 956, 962, 964, 964, 968, 969, 982, 983, 984, 1011, 1040, 1041, 1047, 1051, 1057, 1079, 1085, 1089, 1090, 1113, 1115, 1223,

1245

333, 670, 716

967 :באלחרף

:ואלחרף: 569, 676, 957, 968,

970

615, 627

922

715 :פחרף:

711

חרפא: 283, 582, 713, 845, 903, 903, 906, 913, 915, 1077 :חרפאן: 130, 144, 186, 334, 545, 616 832, 833 
:חרפין 275, 420, 486, 567, 577, $583,587,616,627,628$, 672, 1046

: 192, 253, 340, 351,

1117

: 517, 1085, 1087, 1090

275 : וחרפין 216,62

616, 628 :לחרפין

: 1146, 1153

854, 893

697 : ואלחרק: 6548

חקרֶ: 478

555

366, 620, 646

162

:טעאם 223

טעם: 147, 152, 215, 449, 1125 , 1199, 1248, 1249

: 3, 6, 12, 15, 16, 445, 455, 1200, 1218, 1219,

1220, 1221, 1224, 1238,

$1242,1245,1258,1260$,

1262, 1265, 1268

:בטעם 1246, 1255

: 148, 950

951

160

132 :וטעמה 160

1266, 1267

74 :אלטפחה 766

טהור: 228, 232
יגזי 800

722

461

902 :אליהא

687 :יואצעהא : 602

יוד: 150, 150, 324, 420, 476, 476

:אליוד: 192, 322, 367, 477, 480, 484, 621, 646, 697, 894, 897, 902

594, 595, 598

152

ואליוד: 268, 892

937 :ביודין 988,8

1187 :יחדפהא :ביודיו

523-524 :יחיי בן דאווד אלמגרבי :יחדפר :ימנוד

99 :ינגמו 961

461

יסכי 807, 827, 830, 831, 954

1007 :יסתופא: יסאר

999, 1014

יפבם 587, 588, 589, 592, 603, 603

502 :ירפיהא

יתחרך: 678, 801, 809, 832,

861, 969, 973, 1042

980 :אליתיב

184 :אלכאדם

956 :ואלכאדם 184

184 :כאדמא

29, 31 :באדמין 


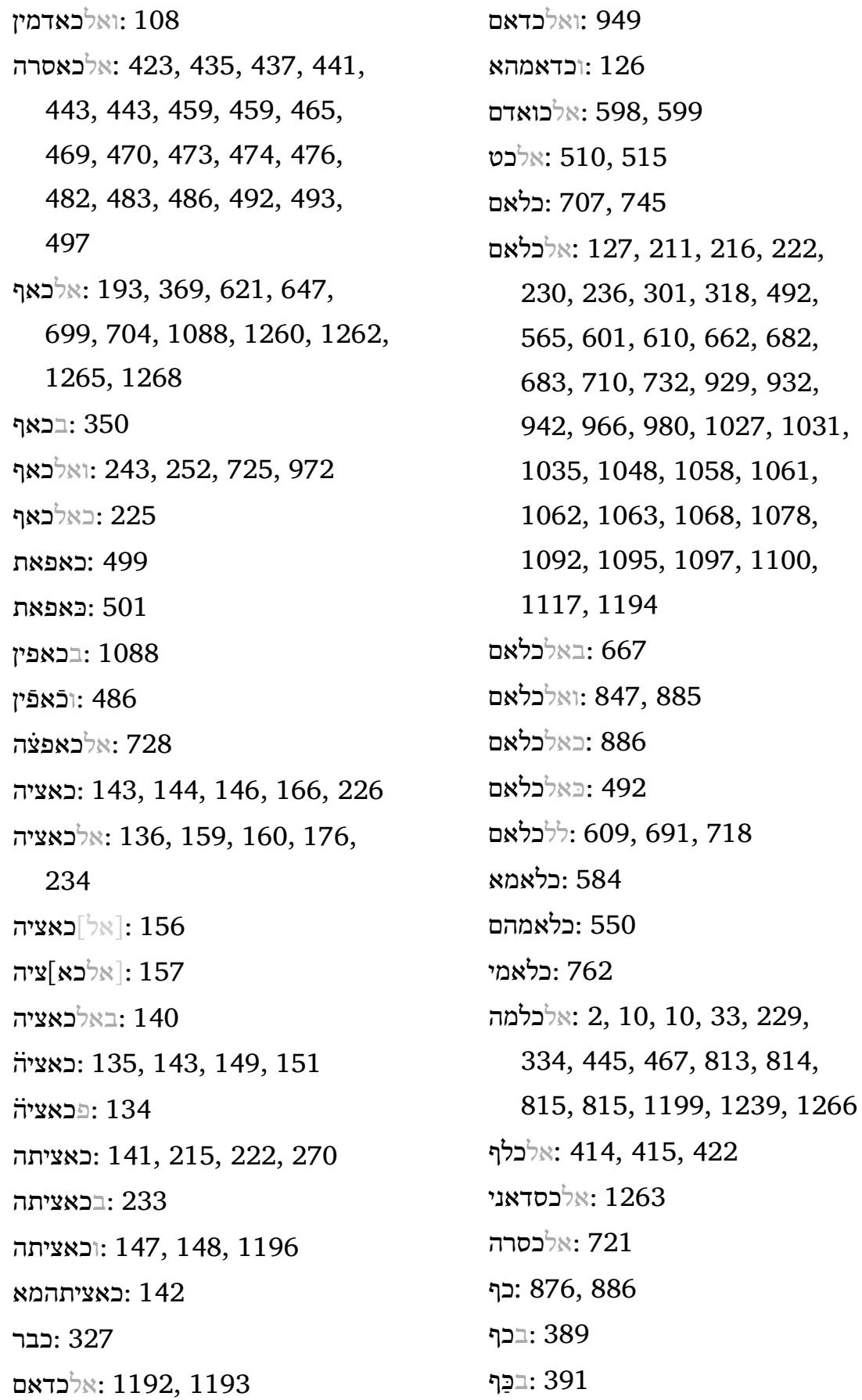


298, 862, 911, 916 681

: אלכפץ: 727, 739, 785, 788, 790, 797

734 : וכפץ

786 721, 724, 742

786 :ללכפن

911

725 :ואללאם : 1911

155

292 :אללגאת :

:לגה 13, 13, 319, 395, 397,

571, 572, 574, 575, 575,

719, 740, 773, 797, 799,

935, 935, 936, 937, 939,

1263

: 22, 35, 114, 278, 292, 301, 330, 526, 528, 528,

566, 566, 581, 608, 639,

684, 685, 686, 692, 729,

734, 735, 747, 943, 1058,

1175, 1176

635, 635

314: ואללגה :בילגה

730 :ללגה

801

609 :אללגויין :

לחן: 60, 105, 107, 108, 463,

980,1180
: 2, 7, 11, 14, 17, 32, 174, 461, 463, 960, 962, 968,

1112, 1115, 1183

73, 76, 77, 185,5, 1205

:באללחן 336, 513, 1124

975

956, 973

524 :ואללין

למאד : 138, 151

:153, 317, 374, 556,

622, 648, 868, 917, 1220,

1222

139, 151

918 :ללמאד

: 205, 250, 252, 253,

255, 258, 261, 268, 268,

1138, 1139, 1140

: 177, 226, 227, 315,

316, 320, 510, 514, 518

157 :באללפט

4 :ואללפט:

587 :פאללפט :

423, 1120

לפטה: 189, 425, 431, 515, 570,

582, 763, 817, 1040, 1046

: 569, 777, 811

482, 672

266, 267

473 :לפטתין

818 :אללפטתין 
לשון 540, 542, 1189, 1189, 1206, 1206, 1208, 1257, 1259

206, 218, 1134

:במאם 599

1049 : ומאם 1049

192, 763, 955

1112

30 :ואלמארכה

898

:אלמאם 622, 649, 891, 991, 1208, 1219

339 :אלמאמין

3, 17, 702

776 :אלמאציה $78,70:$

78, 79, 107

31 :אלמארכה

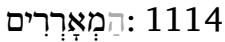

1114 :הַמְבְקְשׁים 1114

1033 :מבתדא

1034 :אלמבתדא

1039 :מבתדאה

667 :אלמבתדי 6303

723 :אלמגזום :אמתריר

1109 :הַמְדברבר

1113 :הַמְדברברִּים

1048 :-המדמדברים

מדגוש: 513, 520, 925, 925,

1086, 1217

475 :מדגושא 45

מדגושה: 252, 298, 501, 1228
275 :מדגושין

260, 272

2

22, 28

: 136, 146, 158, 684, 687

1130 :מוארבה

589

1097, 1099

16

595 :אלמונתה

מחט: 514, 813, 814, 815, 816, 1030, 1044, 1048, 1070, 1071, 1101

1043 :אלמחט

1116 :הַמְחָכִים

מחל 202, 205, 206, 217, 219, 236, 248, 248, 253, 255, $271,274,285,302,302$, 302, 304, 311, 342, 347, $352,357,360,362,366$, $372,376,378,382,385$, 388, 389, 392, 1138, 1140, 1142, 1144, 1146, 1147

205, 1133

299 :המִטַהּר 201

300

899

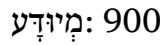

מים: 391, 396, 597, 1243

298 :אלמים 


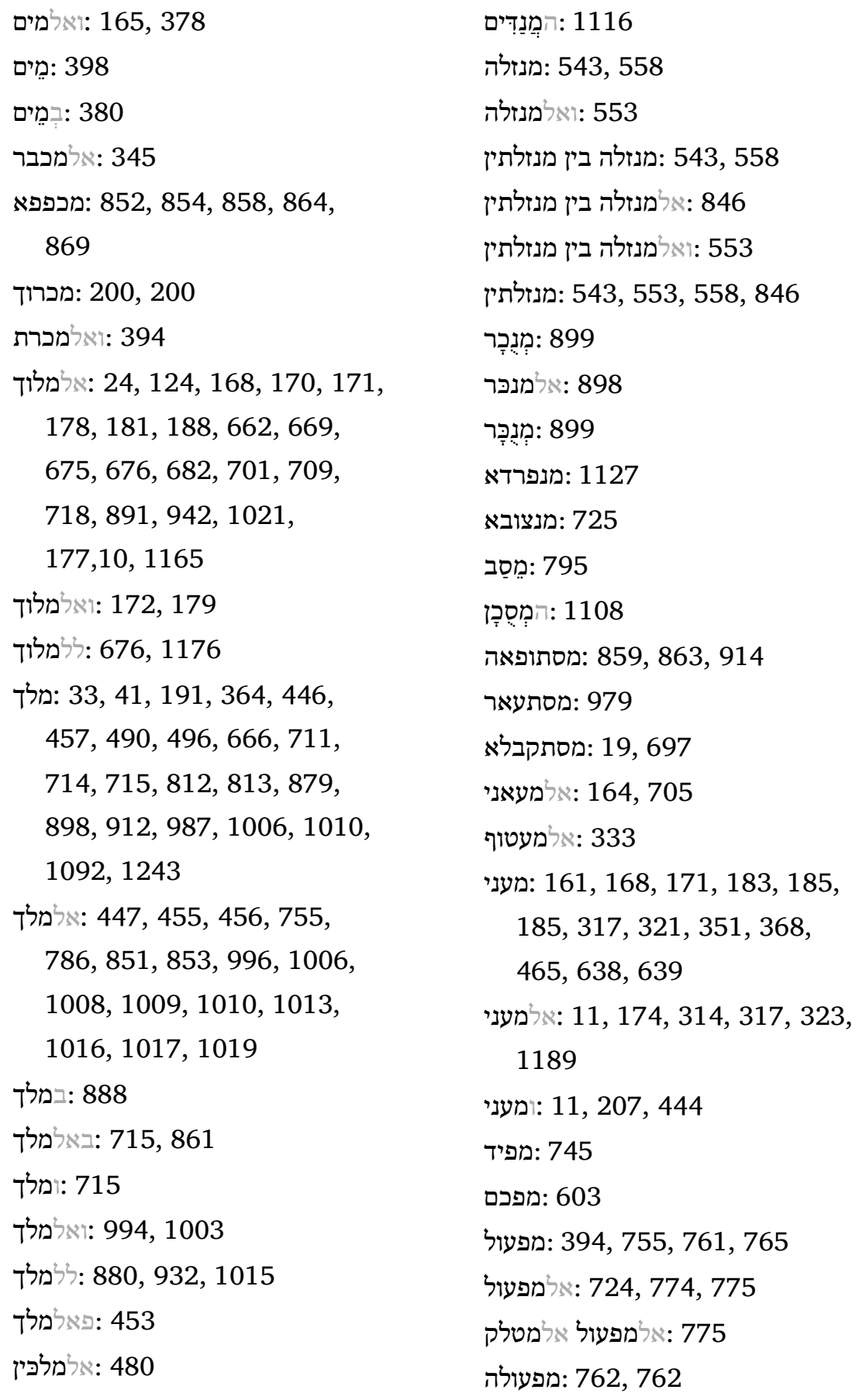


:מפק 465, 465, 470, 476

מפק 419, 420, 420

312

998 :מפתוחה

780 :אלמצאדר :מפתר

780 :אלמצאדר אלמסתעארה

1002 :אלמצאחף מסתארח

1003 :ואלמצאחף

502 :מצאחפה

700 :מצדר :502

775 :אלמצדר

1179 :מצחאפא :אלדר

1183

325, 394

147 :אלמצאפה :מצאה

325 :מצמר

118 :מקטעה

813 :ומקטהא :מקטרה

516, 1252

: 1250, 1255

1125 :אלמקף 1250,125 :מקר

במקף: 1224, 1240, 1246, 1248, 1252

:209, 500, 577, 928,

1187, 1221, 1247, 1253

459 :מרחיק

724

471, 516 :מרפי :מרפוע

405

409 :מרפיה 405

846 :אלמרפיה
275 :מרפיין

249, 254, 259, 273

549 :המרכבה :אריון

550 :במרכבת : 5490

1212 :בִמִרכבת משרת

1109 : 109

1086 :משדד 1109

688 :אלמתואצע

171, 282

מתחרך: 930, 1027, 1033, 1035, 1036, 1036, 1037, 1042, 1043, 1061, 1061, 1063, 1071, 1074, 1076, 1090, 1106, 1108, 1115, 1258, 1260, 1267

: 744, 805, 826, 839,

$841,843,844,928,961$, 977, 983, 987, 1011, 1033, 1051, 1063, 1064, 1078, 1079, 1080

678, 800, 804

: 801, 838, 953, 1081

805 :וללמתחרך

1084 :כאלמתחרך : 805

840, 1075

678 :פאלמתחרך : 680,107

958 :מתחרכא 9678

1066 :מתחרכין

344 :ללמתכלם

594 :אלמתצרפה

340, 614 :אלמתראדפה 


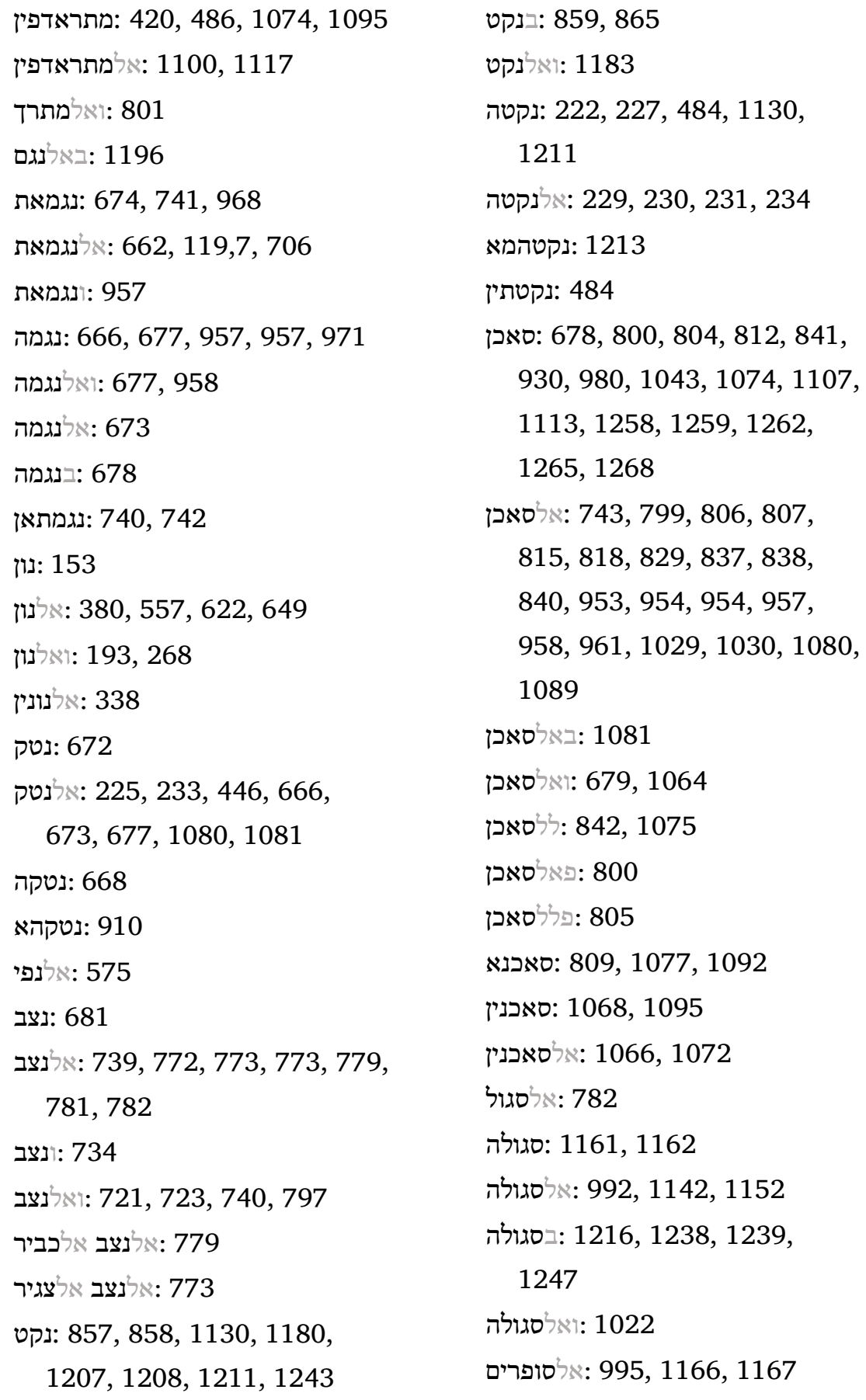


סכון : 1039, 1051, 1079

אלסכון: 833, 834, 1043, 1052,

1054

1041

סכן: 1070, 1125

סלסלה: 78, 79, 108

31 :ואלסלסלה : 198

109 :ללסלסלה

: 382, 556, 623, 650

בסמאך : 388, 392

1162

1143 :אלספלאני

: 752, 783, 786, 790

750, 795

:ליעבר : 778

:אלעבראני 293, 735, 740, 799,

1086, 1264

729, 734, 747, 797 :אלעבראניה 768

758, 767 :אלעבראניין

14

14

332

עין 651, 1226

17, 384, 623, 651, 868,

868,869

212

1136 :באלעלם

:206, 1134

218

1134,106 :עקר הלשון 206

218 :ועקר הלשון
61, 1170

62 :ללעראקיין

720

743 :ללערבי 720

730, 735, 801

ערن 1149, 1150

וערن: 1150, 1151, 1152, 1153,

1153, 1154

252, 268

125

: 493

385, 624

(פא 138, 420, 492

: 225, 305

: 277, 295, 837, 896,

1100

פאטלל 299, 300, 704

724, 748, 778, 787

795 :ואלפאעל

5, 8, 606, 768

756, 757, 758, 759

פאתחה: 920, 921, 945, 1151,

1160, 1161

: 910, 911, 914, 923,

924, 926, 1140

:בפאתחה: 903, 907, 916, 1207,

1214

881 :באלפאתחה

: 169, 922, 1022

891 :ללפאתחה

922 :פאלפאתחה 
79, 305

442 :אלפסק :

439 :ואלפסק : 437

437

297

298, 725, 768

592 :ואלפעל : 59

3, 702

724 :בפעלה :פעלה

[ע] :פר : 254

: 255, 284

1210

196 :פשוטות

29 :אלפשטה

: 701, 721, 741, 883,

884

700, 882, 885

741, 742

741

741 :אלפתחה אלכברי :את

742 :ואלפתחה אלצגרי :אתח אחיפרי

966 :ואלצאד

388, 554, 624

653 :אל] 65

362, 382

164 :ואלצדי 11

1144 :אלצירי :איציר

1244 :בצירי :115

1152

:בצרי :1237, 1249
704 :צֵרי

:צִרִי 478, 1162

720 :אלצמה

322

998, 1150, 1160

: 169, 773, 998, 999,

1008, 1022, 1138

863, 1251

893 :באלקאמצה :ביקמצה

(קאמצתהם 1170

389, 625, 654, 990

:ק39, 1099

892

:699, 703, 890, 990,

991, 1158

990 :ואלקמץ 960

326 :אלקָמִץ :

862

79

1210 :אלרבים

ריש: 198, 541, 560, 561, 655

: 16, 201, 391, 514, 546,

546, 547, 551, 625, 814,

970, 972, 1257

199, 364

560

: ואלריש: 164, 165, 309, 354,

552

955 :כאלריש

544, 549

552 


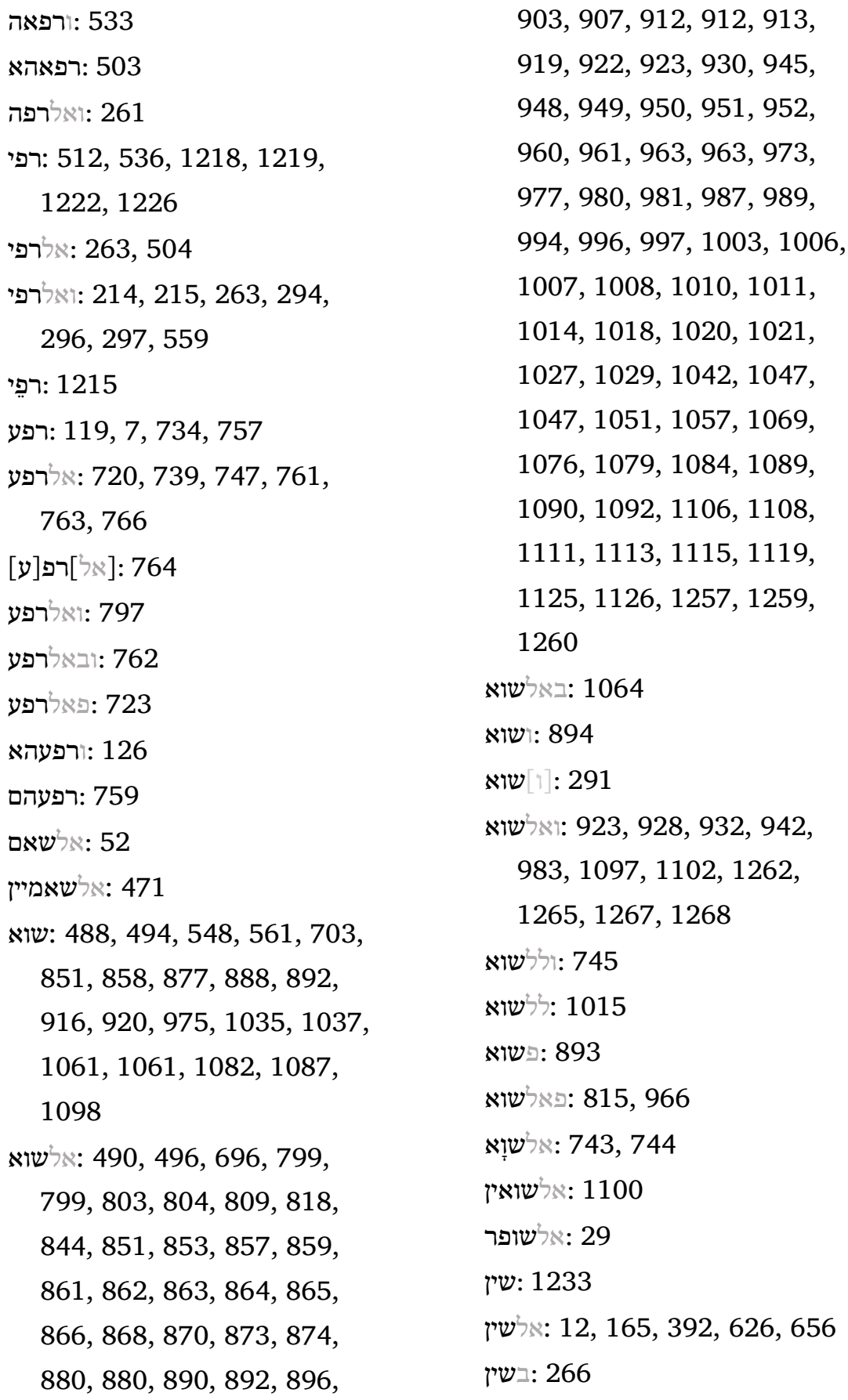


310, 1032

58 :ותנאגימהא

267 :פאלשין

31, 90

793

1024 :אלתנגים

752

90 :אלתנגים

271, 272, 1132, 1147 :אלשפתין

:תנפס: 456, 932, 1194

שרק: 1130, 1131

983 :אלתסכין

:1147, 1154

10 :אלתעריף 10

5אואת: 538, 539

823 :ללתאנית

927 :ללתעריף :אלתעריף 6070

73, 107

607, 630, 631

ות: 515

602, 614, 630, 631

:בתז 366

599 :ותפכים

151

587 :ואלתפכים

261

576, 636, 638

: אלתזו 399, 657

:תפכם 594, 595, 596, 610, 614

ותָ: 150

278 :תואצע 278

25 :אלת[ואצע]

24, 280

598

5צאריף: 566, 748

791, 794, 796

:תציף: 632, 751, 752

23 :פתואצעו

633 :אלתצריף

463 :בתקדיר :633

30 :אלתביר :23

381, 600, 600, 601,

: 516, 535, 536, 542, 555,

611, 640

626, 814, 1103

141 :אלתואצע

919

324, 327, 329, 642

918, 984

124 :ותקילהא

1125

918 :תקל 918

1111

:תלת: 122, 250, 261, 267, 538, : 217, 217, 533

265 :ותקל 2617

734, 818, 1138, 1208, 1225

561

328 :אלתמה

1110 :תקלת :תקלה

34 :תנאגימהא:אותמה 
: 1083, 1098, 1098

133, 487

1068, 1075

232

243 :אלתשדיד

936, 1191

תתקיל :244, 1110

: 242, 242, 247, 921, 924, 945, 1045, 1046, 1047,

1118, 1119

:234, 920

1127 :פאלתתקיל

235

569

\section{TERMS AND WORDS IN}

HIDĀYAT AL-QĀRI'

(SHORT VERSION)

(Numbers refer to lines)

א̣: 134, 308

ي: 134, 308

: 134,308

ي.: 134, 308

ผุ: 134, 308

ผ: 134,308

: 134, 308

אהنה: 27, 28, 196, 255, 263

אוֹ : 50, 51

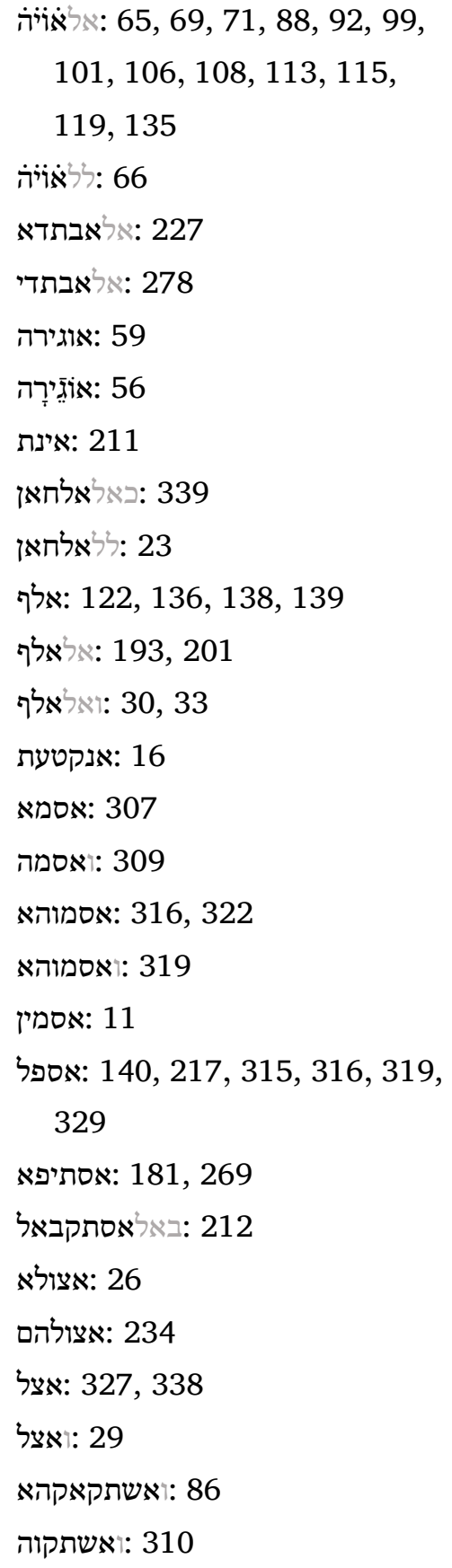


בא: 170, 294

244 :כאלבא

104

: 111, 112

:אלבי :77, 113, 120, 122

46, 92

58

:בית :17, 81, 83

88

ובית 28, 268, 325

28, 325

: 19, 20, 137

228, 228

: 199, 204, 335, 336,

344, 346

181

341 :ללגעיה : מתגיה

30, 30, 35, 77

252

127 :בדגש :אנש

68, 68

57 :ודדחיק : : :

65

56 :ודפסיק :דפסיק

138, 173

: 136, 166, 172, 202, 202, 202

5, 136

הי 15, 33, 57, 85, 86, 116, 122, 172, 231, 316, 319,

336
:אלהי 31, 31, 32, 86, 87

30 ואלהי

:ואו: 57, 91, 91, 139, 211

: 142, 143, 203, 212, 322

157 :אלזאי

48 :בזאי 48

245 :ואלזאי

142

: 136, 346

347 :חדפת

: 10, 240, 265

4, 227, 302

205

310

325 :אלחלם

29, 37

328

141

: 50, 51, 53, 81, 97, 135, 168, 169, 171, 173, 196, 197, 199, 208, 224, 254, 255, 260, 263

: 25, 26, 29, 43, 105, 260

288

247 :אלחרכה

:חרכה 244, 246, 247, 269

188

328, 330 


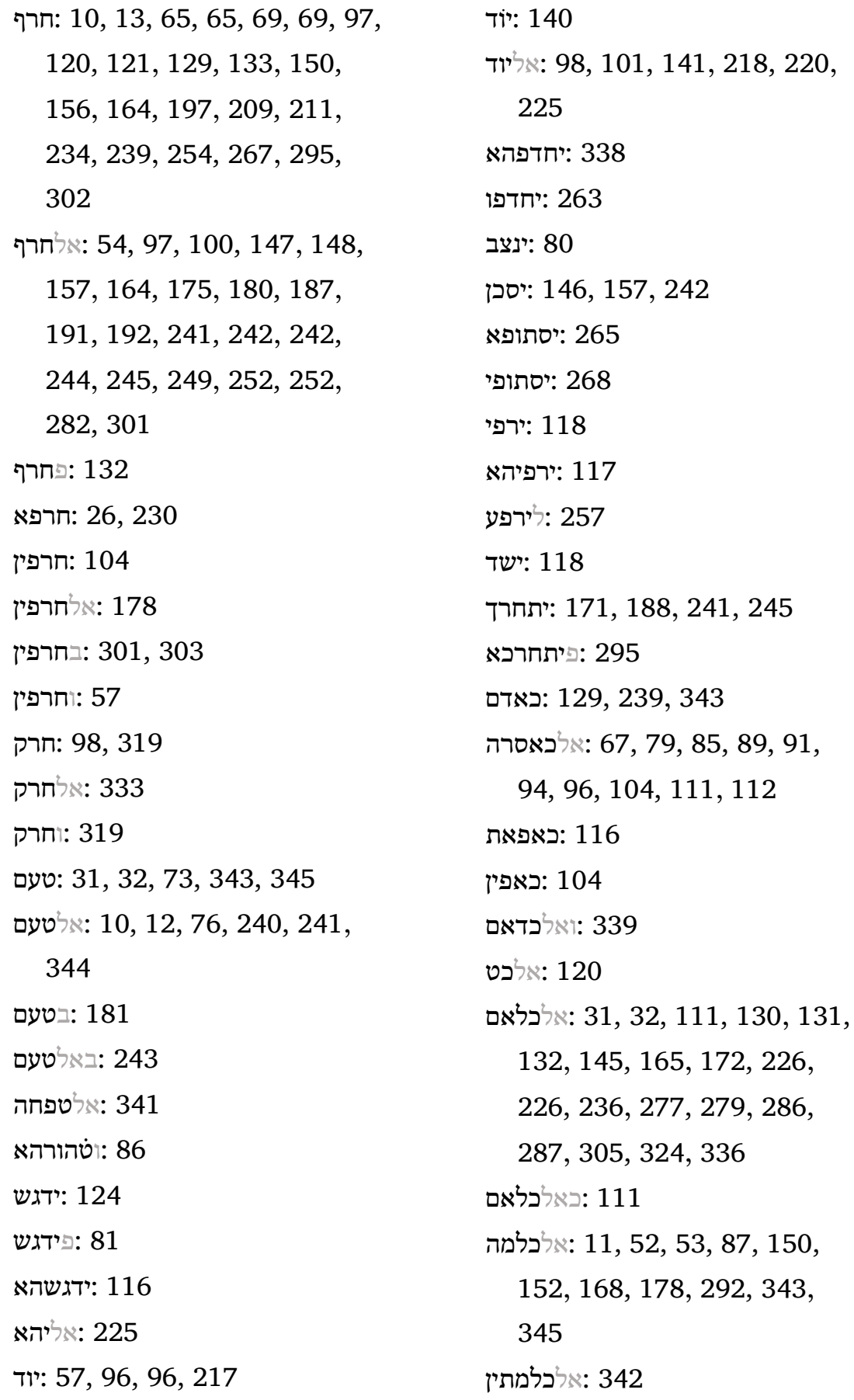


63 :אלכלך

: 210

161

161

54

:כפיפה: 203, 227, 232

233 :לכפתהא

311, 318 :אללגאת : 233

לחן 82, 83, 239, 343

: 11, 13, 68, 80, 174, 246

19, 20

52 :באללחן

129 :ולחן

245 :ואללחן

160 :אללמד : 165

:אללסאן :29, 36, 37, 39, 327,

327, 329

119 :אללפט

129 :אללפטה

103 :בלפצה

126

28, 325 :הלשון

341 :ואלמאילה 325

212 :אלמאצי

213 :באלמאצי

21, 21

120, 302

125

11

321 :מוארבה
9

36, 38

מחט 151, 153

מחל: 25, 325, 327, 329, 330, 332, 333, 334

28, 36, 38, 40, 41, 324

:מיודע 222

221

161

173 :ואלמים: 161

199

138 :אלמלא 199

273

:אלמלוך 131, 134, 143, 307, 308

:מלך 18, 69, 76, 108, 115, 133, 151, 181, 191, 213, 234, 254, 267

:אלמלד 70, 71, 75, 198, 200 , 259, 261, 264, 264, 265, 267, 269, 270

74 :באלמלך

133, 306

221

100, 142

166

222

221

236 :מסתופאה

215 :מסתקבל :מסתופר 236

213 :אלמסתקבל 


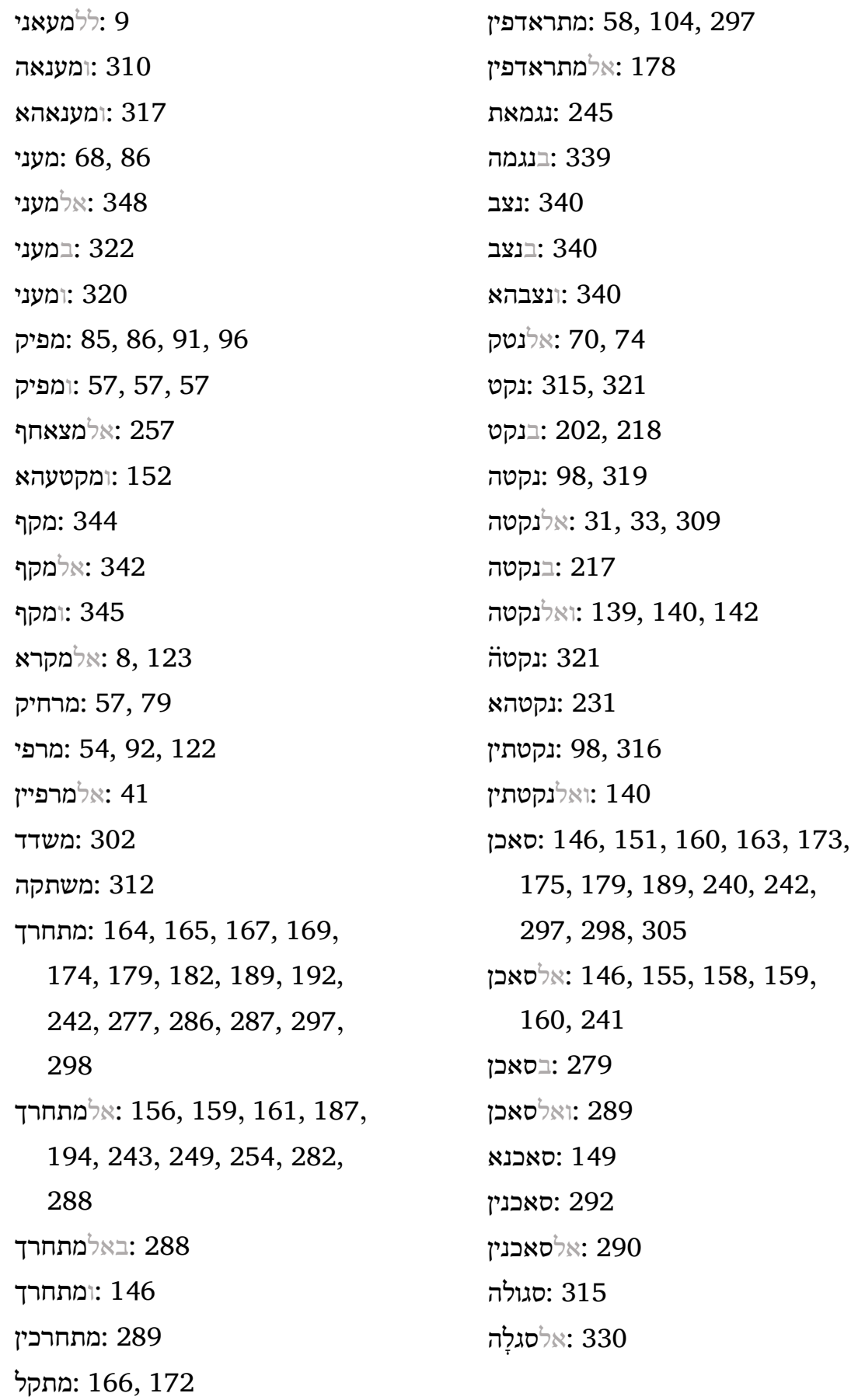


274 :ואלסגלה

סכון 188, 282

193, 283

192 :ואלסכון

293

: 21, 21

47 :בסמאך

331 :אלספלאני

224, 255, 301

206 :אלעין

28

28 :עיקר הלשון

325

325 :עקר הלשון

36 :בערצה :בערות

:231, 235, 313, 329

227

193, 274

228 :ובפאתחה :

232 :אלפאתחה :

215 :אלפעל :215

313

135 :ואלפתח

166

138

294 :ואיצדי :תוסית

316

332

98

ن் 330
312

: 193, 273, 327

203, 204

215 :אלקואמץ :-203,

:135, 137

312

:121, 152

249

92

שוא: 106, 113, 166, 179, 198,

240, 286, 286, 299, 303

: 108, 115, 145, 146,

155, 163, 164, 167, 168,

171, 175, 178, 184, 187,

194, 198, 202, 202, 203,

208, 209, 211, 213, 214,

215, 217, 217, 220, 225,

227, 233, 233, 235, 239,

243, 247, 247, 249, 251,

254, 259, 261, 264, 267,

269, 271, 273, 277, 282,

293, 305

:באלשוא 160, 161, 188, 242,

289

241

189 :ללשוא

169, 173, 181

292, 297

293

157 :ואלשין 
שירה 59

41, 41, 323

שרק : 322

334

152

45

: 294

125

168

:תחרך : 161, 184

251

ת: 126, 128

: 124, 127

: 36,327

:תנפיס 76
336

294 :תסכינהמא

313 :תפתח

83 :בתקדיר

204, 228

252

268 :אלתקל

128 :בתקל :אקל

299 :אלתראדף

105 :תראדפא :אראד

298 :תראדפהמא

347 :אלתתניה

183 :אלתתקיל :אתתניה

180 :באלתתקיל 183 :

164 :פאלתתקיל 


\section{Cambridge Semitic \\ Languages and Cultures}

W

शु,

14

limets

38:

1

General Editor Geoffrey Khan

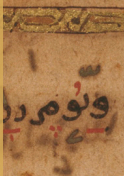

abe

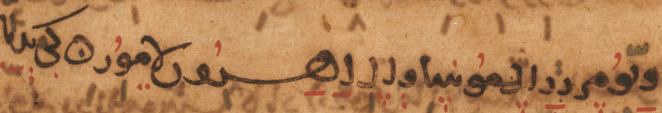

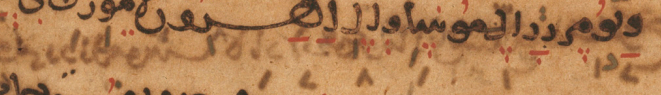

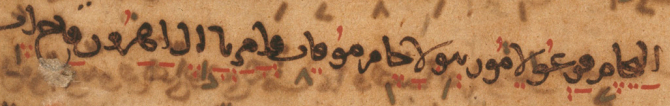

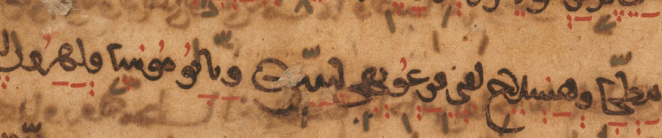

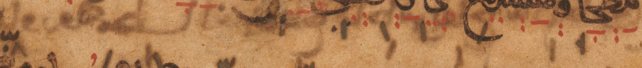

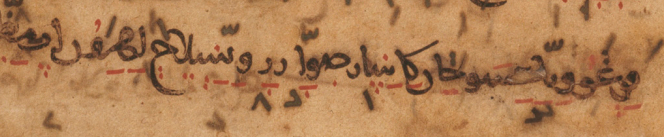

Lt 年 4

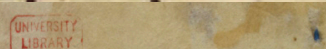

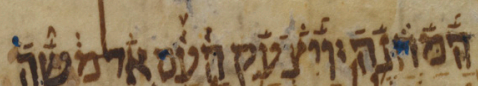

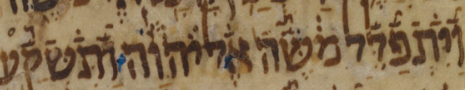

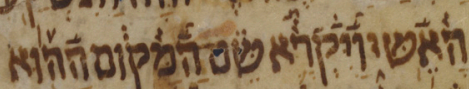

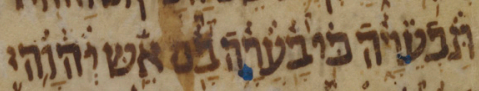

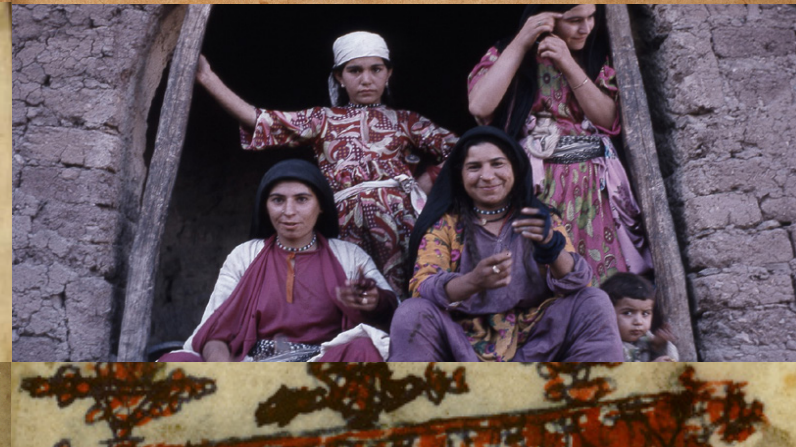
Pulshe

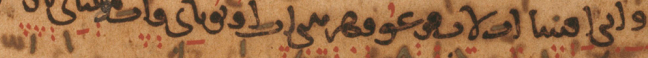
opr $\rightarrow$ 7 is pitolin a d I.

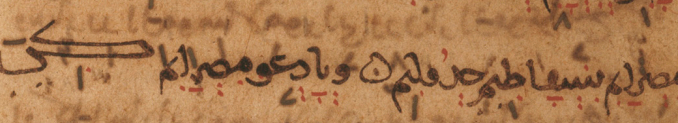
, $4,1,1,2,2$, 10 at $m=x^{2} n=a$ (i)

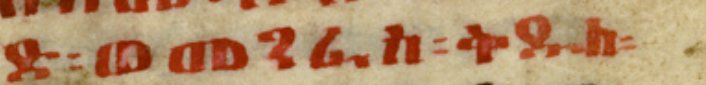

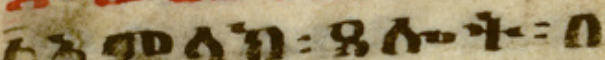




\section{About the series}

This series is published by Open Book Publishers in collaboration with the Faculty of Asian and Middle Eastern Studies of the University of Cambridge. The aim of the series is to publish in open-access form monographs in the field of Semitic languages and the cultures associated with speakers of Semitic languages. It is hoped that this will help disseminate research in this field to academic researchers around the world and also open up this research to the communities whose languages and cultures the volumes concern. This series includes philological and linguistic studies of Semitic languages and editions of Semitic texts. Titles in the series will cover all periods, traditions and methodological approaches to the field. The editorial board comprises Geoffrey Khan, Aaron Hornkohl, and Esther-Miriam Wagner.

This is the first Open Access book series in the field; it combines the high peer-review and editorial standards with the fair Open Access model offered by OBP. Open Access (that is, making texts free to read and reuse) helps spread research results and other educational materials to everyone everywhere, not just to those who can afford it or have access to well-endowed university libraries.

Copyrights stay where they belong, with the authors. Authors are encouraged to secure funding to offset the publication costs and thereby sustain the publishing model, but if no institutional funding is available, authors are not charged for publication. Any grant secured covers the actual costs of publishing and is not taken as profit. In short: we support publishing that respects the authors and serves the public interest.

\section{Other titles of the series}

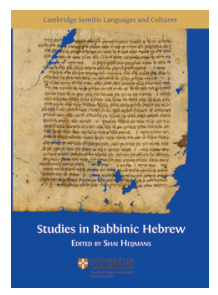

Studies in Rabbinic Hebrew

Shai Heijmans (ed.)

doi.org/10.11647/OBP.0164

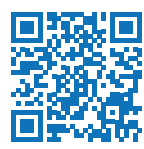

You can find more information about this serie at: http://www.openbookpublishers.com/section/107/1 


\section{The Tiberian Pronunciation Tradition of Biblical Hebrew (Vol. II)}

\section{Geoffrey Khan}

The form of Biblical Hebrew that is presented in printed editions, with vocalization and accent signs, has its origin in medieval manuscripts of the Bible. The vocalization and accent signs are notation systems that were created in Tiberias in the early Islamic period by scholars known as the Tiberian Masoretes, but the oral tradition they represent has roots in antiquity. The grammatical textbooks and reference grammars of Biblical Hebrew in use today are heirs to centuries of tradition of grammatical works on Biblical Hebrew in Europe. The paradox is that this European tradition of Biblical Hebrew grammar did not have direct access to the way the Tiberian Masoretes were pronouncing Biblical Hebrew.

In the last few decades, research of manuscript sources from the medieval Middle East has made it possible to reconstruct with considerable accuracy the pronunciation of the Tiberian Masoretes, which has come to be known as the 'Tiberian pronunciation tradition'. This book presents the current state of knowledge of the Tiberian pronunciation tradition of Biblical Hebrew and a full edition of one of the key medieval sources, Hidāyat al-Qāri' 'The Guide for the Reader', by 'Abū al-Faraj Hārūn. It is hoped that the book will help to break the mould of current grammatical descriptions of Biblical Hebrew and form a bridge between modern traditions of grammar and the school of the Masoretes of Tiberias.

Links and QR codes in the book allow readers to listen to an oral performance of samples of the reconstructed Tiberian pronunciation by Alex Foreman. This is the first time Biblical Hebrew has been recited with the Tiberian pronunciation for a millennium.

As with all Open Book publications, this entire book is available to read for free on the publisher's website. Printed and digital editions, together with supplementary digital material, can also be found at www.openbookpublishers.com 